FINAL REPORT

$$
\text { AND }
$$

INITIAL UPDATE

$$
\text { OF THE }
$$

ENERGY ECONOMIC DATA BASE (EEDB) PROGRAM PHASE I

PREPARED FOR

\title{
THE U.S. DEPARTMENT OF ENERGY
} UNDER CONTRACT NUMBER EN-78-C-02-4954

\author{
VOLUME II OF III
}

BY

E united engineers

DECEMBER 1979 


\section{DISCLAIMER}

This report was prepared as an account of work sponsored by an agency of the United States Government. Neither the United States Government nor any agency Thereof, nor any of their employees, makes any warranty, express or implied, or assumes any legal liability or responsibility for the accuracy, completeness, or usefulness of any information, apparatus, product, or process disclosed, or represents that its use would not infringe privately owned rights. Reference herein to any specific commercial product, process, or service by trade name, trademark, manufacturer, or otherwise does not necessarily constitute or imply its endorsement, recommendation, or favoring by the United States Government or any agency thereof. The views and opinions of authors expressed herein do not necessarily state or reflect those of the United States Government or any agency thereof. 


\section{DISCLAIMER}

Portions of this document may be illegible in electronic image products. Images are produced from the best available original document. 


\title{
FINAL REPORT
}

\begin{abstract}
OF THE
INITIAL UPDATE

ENERGY ECONOMIC DATA BASE (EEDB) PROGRAM PHASE I
\end{abstract}

This book was prepared as ath accocunt of work sponsored by an agency of the Un led States Governiment Ne ther the Lnited States Government nor any ayency thereot nor any of the t emoloyees makes any comoleteness or usefulness of any intormation apparatus product or process disclosed or represents that his use would not intringe privately owned ights Reference herent to any sprcilic

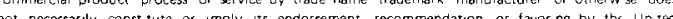

PREPARED FOR

\section{THE U.S. DEPARTMENT OF ENERGY \\ UNDER CONTRACT NUMBER EN-78-C-02-4954}

\section{VOLUME II OF III}

BY

\section{E Inited engineers}

DECEMBER 1979

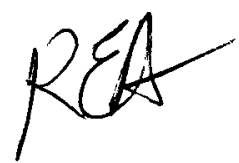




\section{CONTENTS}

FINAL REPORT AND INITIAL UPDATE OF THE ENERGY ECONOMIC DATA BASE (EEDB) PROGRAM PHASE I

Legal Notice

List of Principal Contributors

List of Tables

List of Figures

VOLUME I of III

Title

Section

Introduction

Description of the Energy Economic Data Base

Assumptions and Ground-Rules for Initial Cost Update

Summary of Initial Cost Update

Capital Cost Initial Update

Fuel Cycle Cost Initial Update

Operation and Maintenance Cost Initial Update

References and Glossary

VOLUME II of III

\section{$\underline{\text { Appendices }}$}

Description of Standard Hypothetical Middletown Site

for Nuclear Power Plants

Description of Standard Hypothetical Middletown Site for Coal-Fired Plants

Summary of NUS Corporation Fuel Cycle Work

B

Inflation-Free Fixed Charge Rates

C-1

Capital Cost Update Procedure

Combustion Engineering, Inc. LMFBR NPGS Target Nuclear Steam Supply System 


\section{CONTENTS (continued) \\ FINAL REPORT AND INITIAL UPDATE OF THE ENERGY ECONOMIC DATA BASE (EEDB) PROGRAM PHASE I}

\section{VOLUME III of III}

Appendices

Section

Practical Target Economics for the Liquid Metal Fast Breeder

Reactor Nuclear Power Generating Station

D-2

Air Quality Impact Analysis for Determination of the Acceptability of Qualified High and Low Sulfur Coal-Fired

Facility Designs for the Hypothetical Middletown Site

D-3

Synthetic Power Plant Fuels by the Solvent Refined Coal Process

$\mathrm{D}-4$

Inflation-Free Fuel Cycle Costs for "Throwaway" and

Recycle Cases

E-1

Inflated (6\%) Fue1 Cycle Costs for "Throwaway" and

Recycle Cases

$\mathrm{E}-2$

Inflated (7\%) Fuel Cycle Costs for "Throwaway" and Recycle Cases

$\mathrm{E}-3$

Inflated (8\%) Fuel Cycle Costs for "Throwaway" and Recycle Cases

$$
\mathrm{E}-4
$$

Fue1 Costing Methodology

$\mathrm{F}$

Bred Fuel Scenarios 
APPENDIX A-1 


\section{APPENDIX A-1}

\section{DESCRIPTION OF STANDARD HYPOTHET ICAL MIDDLETOWN SITE}

\section{FOR NUCLEAR POWER PLANTS}

\section{SITE DESCRIPTION}

\section{A1.1 GENERAL}

This site description provides the site and environmental data, derived from Appendix A of "Guide for Economic Evaluation of Nuclear Reactor Plant Designs", USAEC Report NUS-531, modified to reflect current requirements. These data form the bases of the criteria used for designing the facility and for evaluating the routine and accidental release of radioactive liquids and gases to the environment.

\section{A1.2 TOPOGRAPHY AND GENERAL SITE CHARACTERISTICS}

The site is located on the east bank of the North River at a distance of twenty-five miles south of Middletown, the nearest large city. The North River flows from north to south and is one-half mile (2600 ft) wide adjacent to the plant site. A flood plain extends from both river banks an average distance of one-half mile, ending with hilltops generally 150 to $250 \mathrm{ft}$ above the river leve1. Beyond this area, the topography is gently rolling, with no major critical topographical features. The plant site itself extends from river level to elevations of $50 \mathrm{ft}$ above river level. The containment building, other seismic Category I structures and the switchyard are located on level ground at an elevation of $18 \mathrm{ft}$ above the mean river level. This elevation is ten feet above the 100-year maximum river leve1, according to U.S. Army Corps of Engineers' studies of the area.

In order to optimize land area requirements for the nuclear power plant site, maximum use of the river location is employed. The containment structure is located approximately $400 \mathrm{ft}$ from the east bank of the river. The site land area is taken as approximately 500 acres. 


\section{A1.3 SITE ACCESS}

Highway access is provided to the hypothetical site by five miles of secondary road connecting to a state highway; this road is in good condition and needs no additional improvements. Railroad access is provided by the construction of a spur which intersects the B\&M Railroad. The length of the required spur from the main line to the plant site is assumed to be five miles in length. The North River is navigable throughout the year with a $40 \mathrm{ft}$ wide by $12 \mathrm{ft}$ deep channe1. The distance from the shoreline to the center of the ship channel is $2000 \mathrm{ft}$. All plant shipments are assumed to be made overland except that heavy equipment (such as reactor vessel and generator stator) may be transported by barge. The Middletown Municipal Airport is located three miles west of the State highway, 15 miles south of Middletown, and ten miles north of the site.

\section{A1.4 POPULATION DENSITY AND LAND USE}

The hypothetical site is near a large city (Middletown, 250,000 population) but in an area of low population density. Variation in population with distance from the site boundary is:

\begin{tabular}{rr} 
Miles & $\begin{array}{r}\text { Cumulative } \\
\text { Population }\end{array}$ \\
\hline 0.5 & 0 \\
1.0 & 310 \\
2.0 & 1,370 \\
5.0 & 5,020 \\
10.0 & 28,600 \\
20.0 & 133,000 \\
30.0 & $1,010,000$
\end{tabular}


There are five industrial manufacturing plants within 15 miles of the hypothetical site. Four are small plants, employing less than 100 people each. The fifth, near the airport, employs 2,500 people. Closely populated areas are found only in the centers of the small towns so that the local land area used for housing is sma11. The remaining land, including that across the river, is used as forest or cultivated crop land, except for railroads and highways.

\section{A1.5 NEARBY FACILITIES}

Utilities are available as follows:

- Natural gas service is available two miles from the site boundary on the same side of the river.

- Communication lines are furnished to the project boundaries at no cost.

- Power and water for construction activities are available at the southwest corner of the site boundary.

- Two independent offsite power sources (one at $500 \mathrm{kV}$ and one at $230 \mathrm{kV}$ ) are available at the switchyard.

\section{A1.6 METEOROLOGY AND CLIMATOLOGY}

\section{A1.6.1 Ambient Temperatures}

The winters in the Middletown area are moderately cold, with average temperatures in the low 30s. The summers are fairly humid with average temperatures in the low 70s, and with high temperatures averaging around $82^{\circ} \mathrm{F}$. The historic maximum wet bulb and dry bulb temperatures are $78^{\circ} \mathrm{F}$ and $99^{\circ} \mathrm{F}$ respectively.

The year-round temperature duration curves for the dry bulb temperatures and coincident wet bulb temperatures are shown in Figure Al.1. 


\section{A1.6.2 Prevailing Wind}

According to Weather Bureau records at the Middletown Airport, located ten miles north of the site on a low plateau just east of the North River, surface winds are predominantly southwesterly $4-10$ knots during the warm months of the year, and westerly 6 - 13 knots during the cool months.

There are no large diurnal variations in wind speed or direction. Observations of wind velocities at altitudes indicate a gradual increase in mean velocity and a gradual veering of the prevailing wind direction from southwest and west near the surface to westerly and northwesterly aloft.

In addition to the above, studies of the area indicate that there is a significant channeling of the winds below the surrounding hills into the northsouth orientation of the North River. It is estimated that winds within the river valley blow approximately parallel to the valley orientation in excess of 50 percent of the time.

\section{A1.6.3 Atmospheric Diffusion Properties}

The transport and dilution of radioactive materials in the form of aerosols, vapors or gases released into the atmosphere from the Middletown nuclear power station are a function of the state of the atmosphere along the plume path, the topography of the region, and the characteristics of the effluents themselves. For a routine airborne release, the concentration of radioactive materials in the surrounding region depends on the amount of effluent released, the height of the release, the wind speed, atmospheric stability, and airflow patterns of the site, and various effluent removal mechanisms. Geographic features such as hills and valleys influence diffusion and airflow patterns. 
of the diffusion models that have been developed, the straight-line trajectory model is utilized to calculate the atmospheric diffusion from the Middletown site.

The straight-line trajectory model assumes that the airflow transports and diffuses effluents along a straight line through the entire region of interest in the airflow direction at the release point. The version of this model which is used is the Gaussian straight-line trajectory mode1. In this mode1, the wind speed and atmospheric stability at the release point are assumed to determine the atmospheric diffusion characteristics in the direction of airflow.

A long-term continuous release is assumed whose effluent is distributed evenly across a 22-1/2 degree sector. The model treats elevated-only, groundlevel only, or mixed elevated-ground level releases, as determined by the interaction of plant characteristics and wind speeds.

For elevated releases, the basic equation, modified from Turner (1970), is:

$$
\frac{\bar{X}}{Q}(x, k)=\frac{2.032 \cdot R F_{k}(x)}{x} \sum_{1 !} \frac{D E P L_{i j k}(x) \cdot D E C_{i}(x) \cdot f_{i j k} \exp -\left(\frac{1}{2} \frac{h_{e}^{2}}{\sigma_{z j}^{2}(x)}\right)}{\bar{u}_{i} \sigma_{z j}(x)}
$$

where

$$
\begin{aligned}
\frac{\bar{X}}{Q}(x, k)= & \begin{array}{l}
\text { average effluent concentration normalized by source } \\
\text { strength at distance } x \text { and direction } k ;
\end{array} \\
\bar{v}_{i}= & \text { mid-point values of the ith wind speed class; } \\
\sigma_{z j}(x)= & \text { vertical }(z) \text { spread of effluent at distance } x \text { for } \\
& \text { the jth stability class; }
\end{aligned}
$$




$$
\begin{aligned}
f_{i j k}= & \text { joint probability of the ith wind speed class, } j \text { th } \\
& \text { stability class, and } k \text { th wind direction; } \\
= & \text { downwind distance from release point or building; } \\
= & \text { effective plume height; } \\
h_{e}= & \text { reduction factor due to radioactive decay at distance } \\
& \text { x for the ith wind speed class; } \\
D_{i}(x)= & \text { reduction factor due to plume depletion at distance } x \\
& \text { for the ith wind speed class, jth stability class, and } \\
& \text { kth wind direction; and } \\
= & \text { correction factor for air recirculation and stagnation } \\
& \text { at distance } x \text { and kth wind direction. }
\end{aligned}
$$

Ground release concentrations are calculated using the following two equations modified from Turner (1970):

$$
\begin{aligned}
& \frac{\bar{X}}{Q}(x, k)=\frac{2.032}{x} R F_{k}(x) \sum_{i j} D E P L_{i j k}(x) \cdot D E C_{i}(x) \cdot f_{i j k}\left[\bar{v}_{1}\left(\sigma_{z j}^{2}(x)+D_{z}^{2} / \pi\right)^{1 / 2}\right]^{-1} \\
& \frac{\bar{X}}{Q}(x, k)=\frac{2.032}{x} R F_{k}(x) \sum_{i j} D E P L_{i j k}(x) \cdot D E C_{i}(x) \cdot f_{i j k}\left(\sqrt{3} \bar{u}_{i} \sigma_{z j}(x)\right)^{-1}
\end{aligned}
$$

Where $D_{z}$ is the building height which is used to describe the dilution due to the building wake, from Yanskey, et al (1966). Equation 3 represents the maximum building wake dilution allowed; the higher value of $\overline{X / Q}$ calculated from Equations 2 and 3 is utilized.

Values of $\frac{\bar{X}}{Q}(x, k)$ are calculated at 22 downwind distances between 0.25 and 50 miles. Each of the 16 directional sectors are divided into 10 downwind segments and an average value is determined for each sector as follows: 
$(X / Q)_{s e g}=\frac{R_{1}(X / Q)_{R_{1}}+r_{1}(X / Q)_{r_{1}}+\cdots+r_{n}(X / Q)_{r_{n}}+R_{2}(X / Q) R_{2}}{R_{1}+r_{1}+\cdots+r_{n}+R_{2}}$

where

$$
\begin{aligned}
& \overline{(X / Q)}_{\text {seg }}=\text { average value of } \overline{X / Q} \text { for the segment; } \\
& {\overline{(X / Q)_{r}}}_{r}=\frac{\bar{X}}{Q}(x=r, k) \text { calculated at distance } r ; \\
& R_{1}, R_{2}=\text { the downwind distance of the segment boundaries; and } \\
& r_{1} \ldots r_{2}=\text { selected radii between } R_{1} \text { and } R_{2} .
\end{aligned}
$$

The effluent plume is depleted via dry deposition using Figures 2 through 5 of Regulatory Guide 1.111, Rev. 1 (1977). These depletion factors are adjusted for changes in topography.

From Slade (1968) the reduction factor due to radioactive decay is:

$\operatorname{DEC}=\operatorname{EXP}\left(-.693 t_{i} / T\right)$

where

$$
t_{i}=x /\left(86400 \bar{u}_{i}\right),
$$

such that $D E C \quad=$ reduction factor due to radioactive decay;

$$
\begin{array}{ll}
T & =\text { half } 1 \text { ife, in days, of the radioactive material; } \\
t_{i} & =\text { travel time, in days; } \\
\times & =\text { travel distance, in meters; and } \\
\bar{v}_{i} & =\text { midpoint of the windspeed class, in meters/second. }
\end{array}
$$

Finally, for the Middletown site, the $\overline{\mathrm{X} / \mathrm{Q}}$ values are amended so that they are not substantially underestimated due to the effects of the regional 
recirculation and stagnation of the air. For downvalley airflow, the relative concentrations are multiplied by five for distances less than 20 miles. For upvalley airflow, the concentrations are multiplied by 1.5 for all distances.

The relative deposition per unit area, $\overline{\mathrm{D} / \mathrm{Q}}$, is calculated by sector for 22 downwind distances and 10 downwind segments between 0.25 and 50 miles. Elevated-only, ground-level only, or mixed elevated-ground level release are utilized depending on the ratio of the effluent exit velocity to the exit leve1 windspeed.

For a 22-1/2 degree sector, the basic equation to calculate the average $D / Q$ for a specified downwind distance is:

$$
\bar{D}(x, k)=\frac{R F_{k}(x) \cdot \sum_{i j} D_{i j} f_{i j k}}{(2 \pi / 16) x}
$$

where

$$
\begin{aligned}
& \bar{D}(x, k)=\text { average relative deposition per unit area at a downwind } \\
& \text { distance } x \text { and direction } k \text {, in meters }{ }^{-2} \text {; } \\
& D_{i j} \quad=\text { the relative deposition rate from Figures } 6 \text { through } 9 \text { of } \\
& \text { Regulatory Guide } 1.111 \text { for the ith wind speed class } \\
& \text { (since plume height is dependent on windspeed) and } j \text { th } \\
& \text { stability class, in meters }{ }^{-1} \text {; } \\
& f_{i j k}=\text { joint probability of the ith windspeed class, } j \text { th stability } \\
& \text { class, and kth wind direction; } \\
& x=\text { downwind distance, in meters; and } \\
& R F_{k}(x)=\text { correction factor for air recirculation and stagnation } \\
& \text { at distance } \mathrm{x} \text { and } \mathrm{kth} \text { wind direction. }
\end{aligned}
$$

Equation 4 is used to calculate average values of $D / Q$ for the downwind segments, with $\mathrm{D}$ replacing $\mathrm{X}$ in the equation. 


\section{A1.6.4 Severe Meteorological Phenomena}

A maximum instantaneous wind velocity of $100 \mathrm{mph}$ has been recorded at the site. During the past 50 years, three tropical storms, all of them in the final dissipation stages, have passed within 50 miles of the site. Some heavy precipitation and winds in excess of 40 miles per hour were recorded, but no significant damage other than to crops resulted.

The area near the site experiences an average of 35 thunderstorms a year, with maximum frequency in early summer. High winds near $60 \mathrm{mph}$, heavy precipitation, and hail are recorded about once every four years.

In forty years of record keeping, there have been twenty tornadoes reported within fifty miles of the site. This moderately high frequency of tornado activity indicates a need to design Seismic Category I structures at the site for the possibility of an on-site tornado occurrence. Maximum tornado frequency occurs in May and June.

During the past forty years, there have been ten storms in which freezing rain has caused power transmission line disruptions. Most of these storms have occurred in early December.

\section{A1.6.5 Potential Accident Release Meteorology}

In the event of an accidental release of fission products to the atmosphere, transport and diffusion is determined by the meteorological conditions at the site for the duration of the accident, which is assumed to be 30 days.

The methodology required to calculate radiation dosages from accidental releases involves a series of procedures. The dosages are based upon a 
ground level release only. Each directional sector from the plant requires a separate $X / Q$ value for the EAB (Exclusion Area Boundary) and the LPZ (Low Population Zone) distances. To evaluate the accident dosages, both the short-term ( $\leq 2 \mathrm{hrs}$ ) and the annual $\times / Q$ values are calculated. The annual $X / Q$ value methodology is taken from Regulatory Guide 1.111, Section C.1.c with the effective height defined as:

$$
h_{e}=h_{s}-h_{t}
$$

where

$$
\begin{aligned}
& h_{s}=\text { stack height } \\
& h_{t}=\text { terrain height }
\end{aligned}
$$

The short-term $X / Q$ values are derived from the conditional equations

$$
\begin{aligned}
& x / Q=1 /\left(\bar{u}_{10} \pi \Sigma_{y} \sigma_{z}\right) \\
& x / Q=1 /\left[\bar{u}_{10}\left(\pi \sigma_{y} \sigma_{z}+A / 2\right)\right] \\
& x / Q=1 /\left(\bar{u}_{10}\left(3 \pi \sigma_{y} \sigma_{z}\right)\right)
\end{aligned}
$$

with

$$
\begin{aligned}
& \bar{u}_{10}=\text { wind speed at ten meters above ground level, } \\
& \sigma_{y}, \sigma_{z}=\text { horizontal and vertical dispersion coefficients, } \\
& \text { A = minimum cross-sectional area of building from which effluent } \\
& \text { is released, } \\
& \Sigma_{y} \quad=\text { latera1 plume spread; a function of atmospheric stability, }
\end{aligned}
$$

For distances greater than 800 meters, $\Sigma_{y}=(M-1) \sigma_{y_{800 m}}+\sigma_{y}$ i

$M$ is a function of atmospheric stability and wind speed, as presented in Regulatory Guide 1.145 (1979), Figure 1. For distances less than 800 meters, $\Sigma_{y}=M \sigma_{y}$. 
The choice of the proper equation determining short-term $X / Q$ values depends upon the procedure below:

1. The higher $X / Q$ value is chosen between equations (2) and (3).

2. If the wind speed is less than $6 \mathrm{~m} / \mathrm{sec}$ and the stability class is greater than or equal to D (i.e.; D, E, F or G stabilities), then the lower $X / Q$ value given by equation (1) or by the higher value of equation (2) or (3) is chosen.

In other words, the values computed from equations (2) and (3) are compared and the higher value is selected. Then, if the meteorological conditions given in Item 2 above are true, the selected value computed from equation (2) or (3) is compared with the value from equation (1), and the lower of these two values is chosen.

The $X / Q$ value selected as the accident dosage is a function of the effective probability level $\mathrm{P}_{\mathrm{e}}$ given by

$$
\mathrm{Pe}_{\mathrm{e}}=\frac{\mathrm{P}(\mathrm{N} / \mathrm{n})}{\mathrm{S}}
$$

where

$$
\begin{aligned}
& \mathrm{P}=\text { probability level which is mandated as five percent for a } \\
& \quad \text { conservative estimate and } 50 \text { percent for realistic. } \\
& \mathrm{N}=\text { total number of valid observations. } \\
& \mathrm{n}=\text { total number of valid observations within a given sector. } \\
& \mathrm{S}=\text { number of sectors. }
\end{aligned}
$$

The short-term $X / Q$ values for each meteorological condition during a given time period are tallied in a cumulative distribution table and normalized to 100 percent. The $X / Q$ distributions for each direction are plotted on cumulative probability paper. The conservative and realistic average 
short-term $X / Q$ values are selected from the graph using the effective probability values. Logarithmic interpolation is performed between the graph-selected $X / Q$ values and the annual average $X / Q$ values at time intervals of eight hours, 16 hours, three days and 26 days for each sector and distance of interest. For each distance, the $X / Q$ accident values for the 16 directions are compared and the highest value is selected.

\section{A1.7 HYDROLOGY}

The North River provides an adequate source of raw make-up water for the station. The average maximum temperature is $75^{\circ} \mathrm{F}$, and the average minimum is $39^{\circ} \mathrm{F}$. The mean annual temperature is $57^{\circ} \mathrm{F}$.

U.S. Army Corps of Engineers' studies indicate that the 100 year maximum flood level rose to eight feet above the mean river level. There are no dams near the site whose failure could cause the river to rise above the eight foot leve1.

\section{Al.8 GEOLOGY AND SEISMOLOGY}

\section{A1.8.1 Soil Profiles and Load Bearing Characteristics}

Soil profiles for the site show alluvial soil and rock fill to a depth of eight feet; Brassfield limestone to a depth of $30 \mathrm{ft}$; blue weathered shale and fossiliferous Richmond limestone to a depth of $50 \mathrm{ft}$; and bedrock over a depth of $50 \mathrm{ft}$. Allowable soil bearing is 6,000 psf and rock bearing characteristics are 18,000 psf and 15,000 psf for Brassfield and Richmond strata, respectively. No underground cavities exist in the limestone. 


\section{A1.8.2 Seismology}

The site is located in a generally seismically inactive region. Historical records show three earthquakes have occurred in the region between 1870 and 1975. A safe shutdown earthquake (SSE) with a horizontal ground acceleration of $0.25 \mathrm{~g}$ provides conservative design margin. For design purposes, the horizontal and vertical component Design Response Spectra given in NRC Regulatory Guide 1.60, Rev. 1, December 1973, are linearly scaled to a horizontal ground acceleration of $0.25 \mathrm{~g}$.

\section{A1.9 SEWAGE AND RADIOACTIVE WASTE DISPOSAL}

\section{A1.9.1 Sewage}

All sewage receive primary and secondary treatment prior to discharge into the North River.

\section{Al.9.2 Gaseous and Liquid Radioactive Wastes}

The gaseous and liquid effluent releases from this plant comply with $10 \mathrm{CFR}$ Part 20 and the intent of Appendix I of 10 CFR Part 50.

\section{A1.9.3 Solid Radioactive Wastes}

Storage on site for decay is permissible but no ultimate disposal on site is planned. 


\section{$\underline{\text { References }}$}

Briggs, G. A., Plume Rise, AEC Critical Review Series, TID-25075, 1969, Clearinghouse for Federal Scientific and Technical Information, Springfield, Virginia.

Turner, D. B., Workbook of Atmospheric Dispersion Estimates, 1970, Office of Air Programs Publication No. AP-26, Environmental Protection Agency, Research Triangle Park, North Carolina.

U.S. Nuclear Regulatory Commission, Regulatory Guide 1.111, Revision 1, Methods for Estimating Atmospheric Transport and Dispersion of Gaseous Effluents in Routine Releases from Light-Water-Cooled Reactors, 1977, USNRC Office of Standards Development, Washington, D. C.

Yanskey, G. R., Markee, E. H., Jr., and Richter, A. P., Climatography of the National Reactor Testing Station, 1960, Idaho Operations Office, USAEC, IDO-12048, Idaho Falls, Idaho.

U.S. Nuclear Regulatory Commission, Regulatory Guide 1.145, Atmospheric Dispersion Models for Potential Accident Consequence Assessments at Nuclear Power Plants, July 1979, USNRC Office of Standards Development, Washington, D.C. 
FIGURE A1.1

TEMPERATURE DURATION CURVES; MIDDLETOWN, U.S.A.

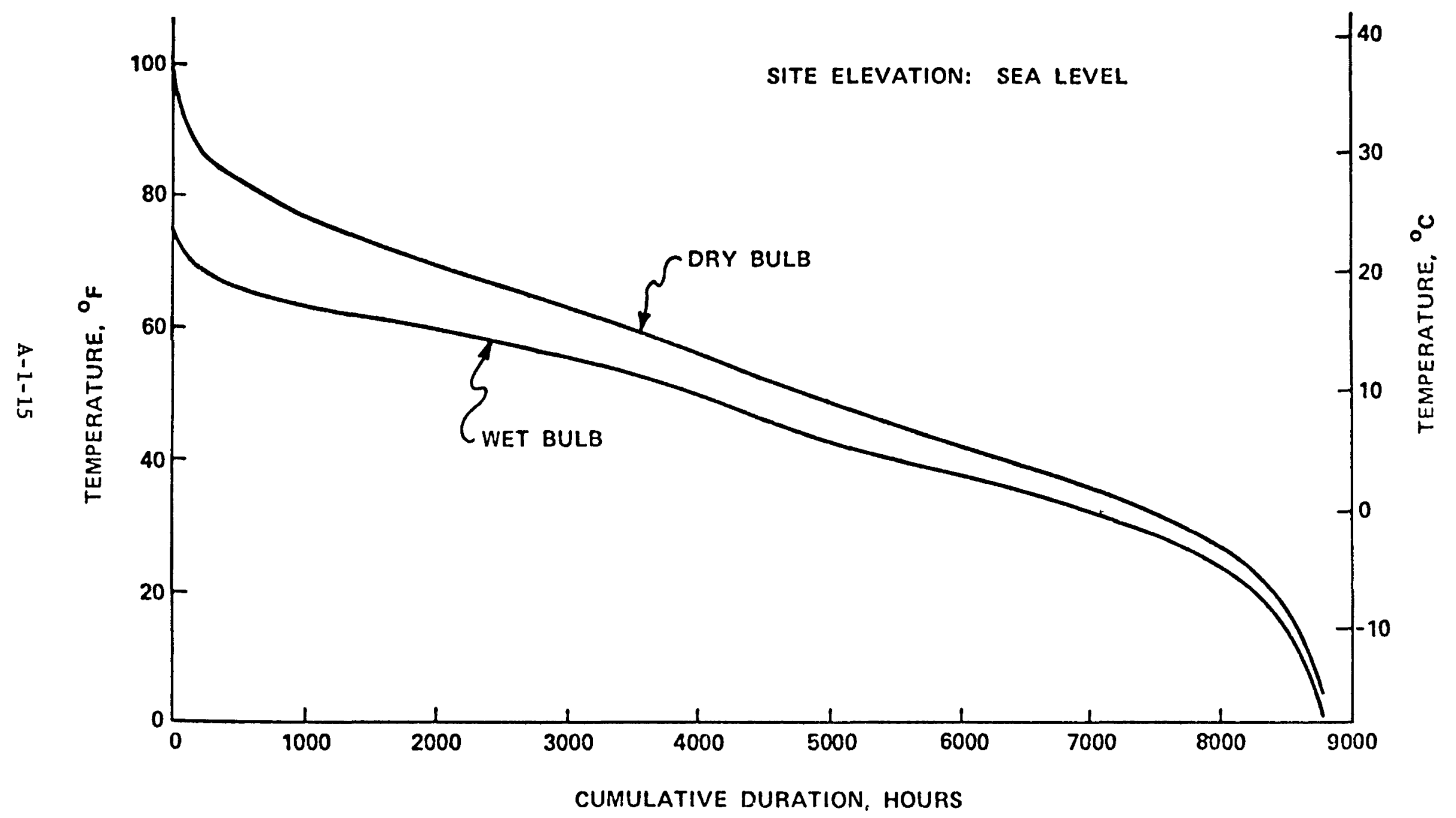


APPENDIX A-2 


\section{DESCRIPTION OF STANDARD HYPOTHETICAL MIDDLETOWN SITE FOR COAL-F IRED PLANTS}

\section{SITE DESCRIPTION}

\section{A2.1 GENERAL}

This site description provides the site and environmental data as derived from Appendix A of "Guide for Economic Evaluation of Nuclear Reactor Plant Designs", USAEC Report NUS-531, and modified to reflect coal plant siting. These data form the bases of the criteria used for designing the facility and for evaluating the release of liquids and gases to the environment.

\section{A2.2 TOPOGRAPHY AND GENERAL SITE CHARACTERISTICS}

The site is located on the east bank of the North River at a distance of approximately twenty-five miles south of Middletown, the nearest large city. The North River flows from north to south and is one-half mile (2600 ft) wide adjacent to the plant site. A flood plain extends from both river banks an average distance of one-half mile, ending with hilltops generally 150 to $250 \mathrm{ft}$ above the river level. Beyond this area, the topography is gently rolling, with no major critical topographical features. The plant site itself extends from river level to elevations of $50 \mathrm{ft}$ above river level. The primary structures and the switchyard are located on level ground at an elevation of $18 \mathrm{ft}$ above the mean river level. This elevation is ten feet above the 100 year maximum river leve1, according to U.S. Army Corps of Engineers' studies of the area.

In order to optimize land area requirements for the coal fueled plant site, maximum use of the river location is employed. The primary structure is located $1200 \mathrm{ft}$ from the east bank of the river. The site land area is approximately 500 acres. An additional 2,000 acres, approximately six miles from the plant site, are available for solid waste disposal. 


\section{A2.3 SITE ACCESS}

Highway access is provided to the hypothetical site by five miles of secondary road connecting to a state highway. This road is in good condition and needs no additional improvements. Railroad access is provided by constructing a railroad spur which intersects the B\&M Railroad. The length of the required spur from the main line to the plant site is assumed to be five miles in length. The North River is navigable throughout the year with a $40 \mathrm{ft}$ wide by $12 \mathrm{ft}$ deep channel. The distance from the shoreline to the center of the ship channel is 2,000 ft. All plant shipments are assumed to be made over land except that heavy equipment may be transported by barge. The Middletown Municipal Airport is located three miles west of the State highway, 15 miles south of Middletown, and ten miles north of the site.

\section{A2.4 POPULATION DENS ITY AND LAND USE}

The hypothetical site is near a large city (Middletown, of 250,000 population) but in an area of low population density. Variation in population with distance from the site boundary is:

Miles

0.5

1.0

2.0

5.0

10.0

20.0

30.0
Cumulative

Population

$$
\begin{array}{r}
0 \\
310 \\
1,370 \\
5,020 \\
28,600 \\
133,000 \\
1,010,000
\end{array}
$$


There are five industrial manufacturing plants within 15 miles of the hypothetical site. Four are sma11 plants employing less than 100 people each. The fifth, near the airport, employs 2,500 people. Closely populated areas are found only in the centers of the small towns, so the total land area used for housing is smal1. The remaining land, including that across the river, is used as forest or cultivated crop land, except for railroads and highways.

\section{A2.5 NEARBY FAC ILITIES}

Utilities are available as follows:

- Natural gas service is available two miles from the site boundary on the same side of the river.

- Communication lines will be furnished to the project boundaries at no cost.

- Power and water for construction activities are available at the southwest corner of the side boundary.

- Two connections to the utility grid (one at $500 \mathrm{kV}$ for the generator connection and one at $230 \mathrm{kV}$ for the reserve auxiliary transformer connection) are available at the switchyard.

\section{A2.6 METEOROLOGY AND CLIMATOLOGY}

\section{A2.6.1 Ambient Temperatures}

The winters in the Middletown area are moderately cold, with average temperatures in the low $30 \mathrm{~s}$. The summers are fairly humid with average temperatures in the low $70 \mathrm{~s}$, and with high temperatures averaging around $82^{\circ} \mathrm{F}$. The historic maximum wet bulb and dry bulb temperatures are $78^{\circ} \mathrm{F}$ and $99^{\circ} \mathrm{F}$ respectively.

The year-round temperature duration curves for the dry bulb temperatures and coincident wet bulb temperatures are shown in Figure A2.1. 


\section{A2.6.2 Prevailing Wind}

According to Weather Bureau records at the Middletown Airport, located ten miles North of the site on a low plateau just east of the North River, surface winds are predominantly southwesterly 4-10 knots during the warm months of the year, and westerly 6-13 knots during the cool months.

There are no large diurnal variations in wind speed or direction. Observations of wind velocities at altitudes indicate a gradual increase in mean velocity and a gradual veering of the prevailing wind direction from southwest and west near the surface to westerly and northwester1y aloft.

In addition to the above, studies of the area indicate that there is a significant channeling of the winds below the surrounding hills into the north-south orientation of the North River. It is estimated that these winds within the river valley blow approximately parallel to the valley orientation in excess of 50 percent of the time.

\section{A2.6.3 Atmospheric Diffusion Properties}

The transport and dilution of materials in the form of aerosols, vapors, or gases released into the atmosphere from the Middletown coal power station are a function of the state of the atmosphere along the plume path, the topography of the region, and the characteristics of the effluents themselves. For a routine airborne release, the concentration of materials in the surrounding region depends on the amount of effluent released, the height of the release, the windspeed, atmospheric stability, and airflow patterns of the site, and various effluent removal mechanisms. Geographic features such as hills and valleys influence diffusion and airflow patterns. 
of the diffusion models that have been developed, the straight line trajectory model is utilized to calculate the atmospheric diffusion from the Middletown site.

The straight-line trajectory model assumes that the airflow transports and diffuses effluents along a straight line through the entire region of interest in the airflow direction at the release point. The version of this model which is used is the Gaussian straight-line trajectory model. In this model, the windspeed and atmospheric stability at the release point are assumed to determine the atmospheric diffusion characteristics in the direction of airflow.

\section{A2.6.4 Severe Meteorological Phenomena}

A maximum instantaneous wind velocity of $100 \mathrm{mph}$ has been recorded at the site. During the past 50 years, three tropical storms, all of them in the final dissipation stages, have passed within 50 miles of the site. Some heavy precipitation and winds in excess of $40 \mathrm{miles} / \mathrm{h}$ were recorded, but no significant damage other than to crops resulted.

The area near the site experiences an average of 35 thunderstorms a year, with maximum frequency in early summer. High winds near $60 \mathrm{mph}$, heavy precipitation, and hail are recorded about once every four years.

In forty years of record, there have been twenty tornadoes reported within fifty miles of the site. Maximum tornado frequency occurs during the months of May and June. 
During the past forty years, there have been ten storms in which freezing rain has caused power transmission line disruptions. Most of these storms have occurred early in December.

\section{A2.6.5 Ambient Background Concentrations}

Background concentrations of $\mathrm{SO}_{2}, \mathrm{NO}_{\mathrm{x}}$ and particulates are typical of a rural area approximately 30 miles from a major industrial metropolitan center. They are considered when determining the plant's adherence to the guidelines.

\section{A2.6.6 Air Quality Estimation}

Ambient pollutant levels are estimated through the application of atmospheric diffusion models. The estimates are based primarily upon the pollutant emissions, meteorology, topography, and background concentration as previously described. Modeling techniques described in the Turner Atmospheric Dispersion Workbook are used for concentration estimates.*

\section{A2. 7 HYDROLOGY}

The North River provides an adequate source of raw makeup water for the station. The average maximum temperature is $75^{\circ} \mathrm{F}$ and the average minimum is $39^{\circ} \mathrm{F}$. The mean annual temperature is $57^{\circ} \mathrm{F}$.

* Turner, D. B., "Workbook of Atmospheric Dispersion Estimates", Public Health Service Publication No. 999-AP-26, U.S. Department of Health, Education, and Welfare, Public Health Service, Consumer Protection and Environmental Health Service, National Air Pollution Control Administration, Cincinnati, Ohio, Revised 1969. 
U.S. Army Corps of Engineers' studies indicate that the 100 year maximum flood level rose to eight feet above the mean river level. There are no dams near the site whose failure could cause the river to rise above the eight foot level.

\section{A2.8 GEOLOGY AND SEISMOLOGY}

\section{A2.8.1 Soil Profiles and Load Bearing Characteristics}

Soil profiles for the site show alluvial soil and rock fill to a depth of eight feet; Brassfield limestone to a depth of $30 \mathrm{ft}$; blue weathered shale and fossiliferous Richmond limestone to a depth of $50 \mathrm{ft}$; and bedrock over a depth of $50 \mathrm{ft}$. Allowable soil bearing is 6,000 psf and rock bearing characteristics are 18,000 psf and 15,000 psf for Brassfield and Richmond strata, respectively. No underground cavities exist in the limestone.

\section{A2.8.2 Seismology}

The site is located in a generally seismically inactive region. Historical records show three earthquakes have occurred in the region between 1870 and 1975.

\section{A2.9 SEWAGE AND LIQUID EFFLUENTS}

All sewage receives primary and secondary treatment prior to discharge into the North River. Other wastewater is discharged in compliance with EPA effluent standards as promulgated in 40 CFR 423. 
FIGURE A2.1

TEMPERATURE DURATION CURVES; MIDDLETOWN, U.S.A.

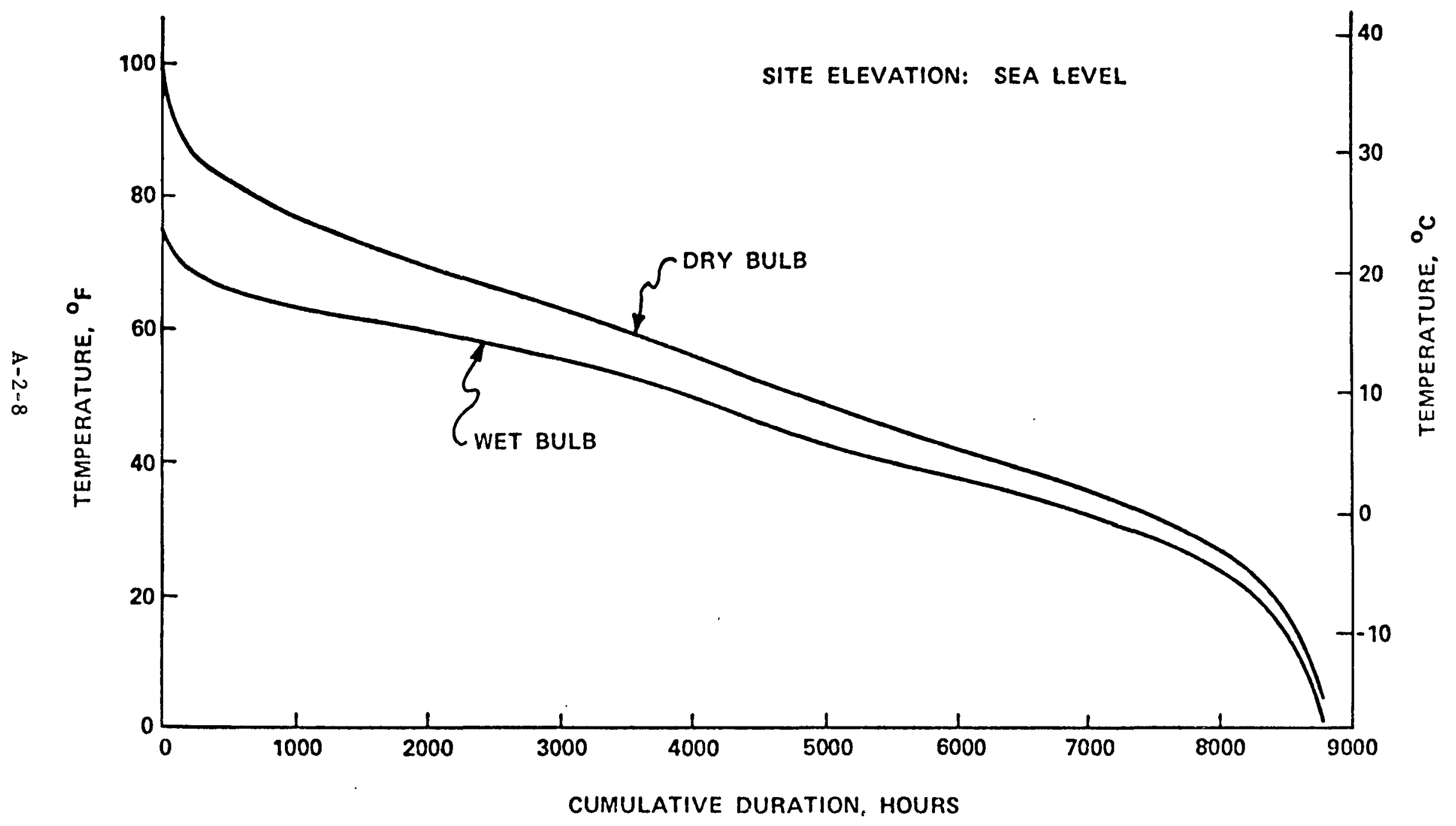


APPENDIX B

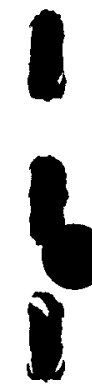


FINAL REPORT

ENERGY ECONOMIC DATA BASE PROGRAM PHASE I

Prepared for

UNITED ENGINEERS \& CONSTRUCTORS, INC.

by

NUS CORPORATION

4 Research Place

Rockville, Maryland 20850

October 1978

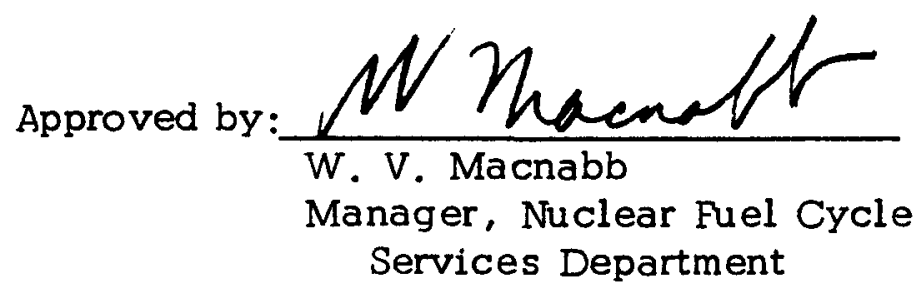




\section{PROPRIETARY INFORMATION STATEMENT}

This report contains information proprietary to NUS Corporation. Neither this report nor its contents may be distributed to third parties without the prior written consent of NUS. 
TABLE OF CONTENTS

Section and Title

PROPRIETARY INFORMATION STATEMENT

LIST OF TABLES

1.0

2.0

3.0

3.1

3.2

3.3

3.4

3.5

3.6

3.7

3.8
INTRODUCTION

SUMMARY OF CONCLUSIONS

REPORT INDEX AND SUMMARY

Task 1 Reports

Task 2 Reports

Task 3 Reports

Task 4 Reports

Task 5 Reports

Task 6 Reports

Task 7 Reports

Task 8 Reports
Page Number

i1

v

$1-1$

$2-1$

$3-1$

3-1

3-3

3-3

3-4

3-5

3-5

3-6

$3-6$

APPENDICES

APPENDIX A

TABLE OF CONTENTS FOR NUS-3190

TABLE OF CONTENTS FOR NUS-3244

APPENDIX B
$A-1$

A-4

B-1 
TABLE OF CONTENTS

(Continued)

Section and Title

Page Number

APPENDIX C

TABLE OF CONTENTS FOR NUS-3196

C-1

TABLE OF CONTENTS FOR NUS-3198

$\mathrm{C}-2$

TABLE OF CONTENTS FOR NUS-3199

$\mathrm{C}-3$

TABLE OF CONTENTS FOR NUS-3203

C-4

TABLE OF CONTENTS FOR NUS-3204

C-5

TABLE OF CONTENTS FOR NUS-3207

C-6

TABLE OF CONTENTS FOR NUS-3209

C-7

TABLE OF CONTENTS FOR NUS-3224

$\mathrm{C}-8$

TABLE OF CONTENTS FOR NUS-3242

C-9

APPENDIX D

TABLE OF CONTENTS FOR NUS-3243

D-1

APPENDIX E

TABLE OF CONTENTS FOR NUS-3223

E-1 


\section{LIST OF TABLES}

Table

No.

$2-1$

$2-2$
TITLE

Page

No.

$2-2$

Costs

(January 1, 1978 Dollars)

Summary of Fuel Cycle Unit Prices

(January 1978 Dollars) 


\subsection{INTRODUCTION}

NUS Corporation has performed consulting eervices for United Engineers and Constructors (UE\&C) under Phase I of the Energy Economic Data Ba se (EEDB) Program. The services performed have been in support of the nuclear fuel cycle work in Phase I.

The scope of services is contained in UE\&C Work Statement 6714-1 of April 4, 1978, which work statement serves as the basis for a subcontract from UE\&C to NUS. The prime contract, Contract No. EN-78-C-02-4954 held by UE\&C, is with the Department of Energy (DOE).

This document is a final report for Phase I of the EEDB Program. It contains the following information:

1. An overall summary of the conclusions of NUS' work on all NUS tasks.

2. An index of each NUS report submitted to UE\&C (and DOE) by task number.

3. A brief summary of each NUS task report, including important conclusions.

4. A Table of Contents of each such report as Appendices to this document. 
The primary objective of NUS' tasks in Phase I of the EEDB Program is to develop baseline technical and cost models for the nuclear fuel cycle, models which display as much detail as possible and which can be periodically updated. Both uranium and thorium fuel cycles have been considered for the following reactor types:

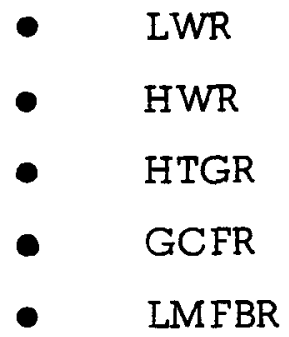

The groundrules for Phase I are presented in SCOPE OF SERVICES of UE\&C Work Statement 6714-1, April 4, 1978.

Following are the principal conclusions resulting from the nuclear fuel cost analyses in Phase I of the EEDB Program:

1. The baseline 30 -year levelized fuel cycle costs for the reactor/fuel cycle systems analyzed in Phase I are given in Table 2-1 for the unit cost inputs shown in Table 2-2.

2. The depletion of uranium is the single largest contributor to fuel costs of the LWR, HWR and HTGR. For the same percentage change in each component of uranium depletion cost, the change in total fuel cost is greatest for the $\mathrm{U}_{3} \mathrm{O}_{8}$ component of that cost. 
TABLE 2-1

SUMMARY OF 30-YEAR LEVELIZED FUEL CYCLE COSTS

(January 1, 1978 Dollars)

Reactor/Fuel Cycle System

PWR/Throwaway

PWR/U\&Pu Recycle

HTGR/Throwaway

HTGR/U-233 Recycle

HWR/(nat. U) Throwaway

HWR/(LEU) Throwaway

HWR/(Th) Throwaway

HWR/(Th) U\&Pu Recycle

LMFBR/Oxide Fuel, U blanket

LMFBR/Oxide Fuel, Th blanket

GCFR/Oxide Fuel, U blanket

GCFR/Oxide Fuel, Th blanket
\$/MBTU for Specified Reactor Startup Date

$\begin{array}{llll}\text { Jan 1,1987 } & 0.72 & \operatorname{Jan} 1,2001 & 0.76 \\ \text { Jan 1, 1991 } & 0.66 & \operatorname{Jan} 1,2001 & 0.67 \\ \operatorname{Jan} 1,1995 & 0.75 & \operatorname{Jan} 1,2001 & 0.76 \\ \operatorname{Jan} 1,1995 & 0.72 & \operatorname{Jan} 1,2001 & 0.73 \\ \operatorname{Jan} 1,1995 & 0.72 & \operatorname{Jan} 1,2001 & 0.73 \\ \operatorname{Jan} 1,1995 & 0.40 & \operatorname{Jan} 1,2001 & 0.40 \\ \operatorname{Jan} 1,1995 & 1.03 & \operatorname{Jan} 1,2001 & 1.04 \\ \operatorname{Jan} 1,1995 & 0.60 & \operatorname{Jan} 1,2001 & 0.62 \\ & & \operatorname{Jan} 1,2001 & 0.39 \\ & & \operatorname{Jan} 1,2001 & 0.48 \\ & & \operatorname{Jan} 1,2001 & 0.45\end{array}$



3. The fuel cycle cost for LMFBR and GCFR is very sensitive to the assumed value of bred fuel, resulting in higher costs as bred fuel values increase.

4. The fuel cycle cost of the PWR and HTGR with recycle is not sensitive to the assumed value of bred fuel.

5. The fuel cycle cost difference between the once-through cycle and recycle of bred fuel in PWR and HTGR systems is small. The fuel cost benefit associated with recycle of bred fuel for these systems is markedly affected by changes in fuel cycle unit prices and assumed inflation rate for the future.

6. The PWR 30-year levellzed fuel cycle cost is representative of that of the LWR, i.e., PWR or BWR, as evidenced by previous NUS evaluations. Furthermore, regarding annual costs experienced by industry, data reported to FERC from 1973 through 1977 show variations of 0.005 to 0.05 \$/MBTU between average annual BWR and PWR fuel costs. (See Table 2 of NUS-3223, A Survey of Fuel Costs for U.S. Nuclear Power Plants 1973-1977.)

7. Increased automation of cost models is justifiable in subsequent phases of the EEDB Program, especially in developing unit costs for $\mathrm{U}_{3} \mathrm{O}_{8}$, fabrication of rod-type fuel, and waste and fuel disposal (and storage) costs. Such automation will reduce future labor efforts, provide greater capability and assure consistency of methodology from year to year. 
8. Mass flows developed under the NASAP Program and evaluated by CRNL should continue to be used in the EEDB Program. If such information should become unavailable for some reason, the next best source is the present NASAP characterization contractor producing such information with data evaluation by NUS. 
The following subsections, 3.1 through 3.8 , contain an index of task reports submitted to DOE and UE\&C during Phase I of the EEDB Program. The second digit of the subsection number (e.g., the digit 2 in subsection number 3.2) corresponds to the NUS task number of UE\&C Work Statement 6714-1 of April 4, 1978.

\subsection{Task I Reports}

The reports in satisfaction of Task 1 are identified and summarized below. A Table of Contents of each report is contained in Appendix A.

NUS-3190 Fuel Cycle Cost Estimates for LWR, HTGR, CANDU-TYPE HWR, LMFBR and GCFR

This report presents the detailed cost inputs and unit cost results for the following reactor/fuel cycle systems:

PWR (throwaway fuel cycle)

PWR (U\&Pu recycle)

HTGR (throwaway fuel cycle)

HTGR (U-233 recycle)

HWR (natural $U$ throwaway fuel cycle)

HWR (LEU throwaway fuel cycle)

LMFBR (oxide fuel, U blanket)

LMFBR (oxide fuel, Th blanket)

GCFR (oxide fuel, U blanket)

GCFR (oxide fuel, Th blanket) 
Both input unit costs and output costs are presented according to a code of accounts developed for Task 4 (see subsection 3.4). Output costs are presented in $\$ /$ MBTU on both an annual and a 30 -year levelized basis.

The report contains identification of cases analyzed, discusses groundrules and assumptions, and presents the fuel cycle cost methodology.

Sensitivity studies are reported for assumed changes in costs for $\mathrm{U}_{3} \mathrm{O}_{8}, \mathrm{SWU}$, fabrication, total back end costs, and bred fuel value. In addition, the variation in 30-year levelized $\$ / M B T U$ resulting from different on-site storage time (PWR and HTGR only) and capacity factor is reported.

NUS-3244 Additional Fuel Cost Studies - Escalation, 2001 Startup and CANDU Thorium System

Thi s report presents nuclear fuel cycle cost inputs and results for the same systems covered in NUS-3190 but with the effects of escalation and a uniform commercial operation date of January 1, 2001. Escalation rates of 6,7 and 8 percent per year are evaluated.

In addition, a CANDU-type HWR on a thorium fuel cycle is selected for evaluation both with and without recycle. The resulting \$/MBTU results show a large incentive to recycle in this system, however, the uncertainties in this result are probably large. 
Task 2 Reports

The results of Task 2 are incorporated into the Task 1 reports already described in subsection 3.1 .

\section{$3.3 \quad$ Task 3 Reports}

The reports in satisfaction of Task 3 are identified and summarized below:

NUS -3237

Recommendations Relating to Acquisition of MassFlow Data for the EEDB Program

This report presents NUS' finding related to sources of fuel cycle mass flow data. Options evaluated for future phases of the EEDB Program include continued use of NASAP data, use of data developed by NASAP contractors but separate from NASAP funding, use of NUFUEL, or development of a code specific to EEDB Program needs.

Our findings are to continue to rely on NASAP data and data evaluation by the national laboratories. Lacking availability of such data, the preferred backup is to rely on NASAP contractors for data with evaluation of such data by NUS.

A Table of Contents of NUS-3237 is contained in Appendix B.

EnSD-FS-528 EEDB Progress Report for Month of August, 1978

With regard to an economics code this report presents our findings that FUELCOST-V is preferred for future use. Furthermore, with some minor changes to the code, costs for future EEDB updates can be reduced. 
The reports in satisfaction of Task 4 are identified and summarized below:

EnSD-FS-471 EEDB Progress Report for Month of July, 1978

This report presents a preliminary listing of a code of accounts for the nuclear fuel cycle.

NUS-3190

Appendix B

and

NUS-3244

Appendices

$A$ and $B$
Fuel Cycle Cost Estimates for LWR, HTGR, CANDU-type HWR, LMFBR and GCFR

Additional Fuel Cost Studies - Escalation, 2001 Startup and CANDU Thorium System

These report appendices present the final cost code of accounts for each reactor/fuel cycle system evaluated in phase I. The accounts are structured in such a way as to accommodate other reactor systems as the need arises and to expand the detail of reporting. The Table of Contents of these two reports is given in Appendix A.

Further detail of the input cost accounts has been developed as part of this task and reported in the Task 5 final reports (see below). 


\section{$3.5 \quad$ Task 5 Reports}

The reports in satisfaction of Task 5 are identified and summarized below. A Table of Contents of each report is contained in Appendix C.

$\begin{array}{ll}\text { NUS-3196 } & \text { Cost of Enrichment Services } \\ \text { NUS-3198 } & \text { UF }_{6} \text { Conversion Cost } \\ \text { NUS-3199 } & \text { Heavy Water Production Costs } \\ \text { NUS-3203 } & \text { Spent Fuel and Reprocessing Waste Disposition } \\ \text { NUS-3204 } & \text { Costs for Spent Fuel Shipping } \\ \text { NUS-3207 } & \text { HTGR Fuel Cycle } \\ \text { NUS-3209 } & \text { Costs of } \mathrm{U}_{3} \mathrm{O}_{8} \\ \text { NUS-3224 } & \text { Reprocessing Cost Model for LWR, LMFBR and } \\ & \text { GCFR }\end{array}$

NUS-3242 Fabrication Costs for "Rodded" Nuclear Fuels

Each of the above nine (9) reports is organized in the same way to describe a base technical model of the material or process being analyzed. Costs are then developed for the fuel cycle component. In most cases costs are developed according to a set of subcomponent cost items. These cost breakdowns are then presented in accordance with the cost accounts developed under Task 4. Cost figures developed in this task are used as input to the computations in Tasks 1,2 and 10.

\section{$3.6 \quad$ Task 6 Reports}

The report in satisfaction of Task 6 is identified and summarized below. A Table of Contents of this report is contained in Appendix D.

NUS-3243

Recommendations Relating to Evaluation of Nuclear Fuel Unit-Cost Data for EEDB Program

This report reviews the needs of the EEDB Program for automation of 
the development of unit cost inputs. The findings of the study result in recommendations for improvements to the uranium price model, and automation of the calculation of fuel fabrication and spent fuel and waste disposal (storage) costs. Manual techniques are recommended for the computation of the other cost components.

\section{7 \\ Task $7^{*}$ Reports}

The report in satisfaction of Task 7 is identified and summarized below. A Table of Contents of this report is contained in Appendix E.
NUS-3 223
A Survey of Fuel Costs for U.S. Nuclear
Power 1973-1977

This report presents statistics reported to the Federal Energy Regulatory Commission (FERC, formerly FPC) on nuclear fuel unit costs (mills/kwhr) and data sources for cost tracking. The tracking procedure is described in EnSD-FS-345. A listing of reactors and their annual fuel expense is tabulated. A simplified statistical analysis is performed on the data for purposes of identifying "high" and "low" cost plants. This data may be useful in subsequent phases of the EEDB Program when choosing specific reactors for further analysis of costs.
3.8
Task $8^{* \star}$ Reports

The reports in satisfaction of Task 8 are NUS-3140 and NUS-3244 which

\footnotetext{
* Numbered as Task 9 in NUS Proposal 7802097 to DOE of March, 1978. $\star \star$ Numbered as Task 10 in NUS Proposal 7802097 to DOE of March, 1978.
} 
have already been discussed under Task 1 . The specific parts of these documents applicable to Task 8 are (see EnSD-FS-471, pp. 3-4):

1. NUS -3190

- effect of capacity factor variations from 0.55 to 0.75

- effect of 10-year spent fuel storage time at reactors with a throwaway fuel cycle (PWR and HTGR only)

- effect of 10-year and 20-year levelized costs in addition to 30 -year levelized costs.

2. NUS-3244

- effect of escalation at rates of 6,7 and 8 percent per year

- effect of a January 1, 2001 commercial operation date for all systems

- costs of a CANDU-type HWR on a thorium fuel cycle 


\section{APPENDIX A}

Table of Contents for NUS-3190

and

Table of Contents for NUS-3244 
$\underline{\text { Section and Title }}$

Page No.

LIST OF TABLES

vi

LIST OF FIGURES

vili

1.0 INTRODUCTION

$1-1$

2.0 SUMMARY

$2-1$

3.0 FUEL COSTING METHODOLOGY 3-1

3.1 FUELCOST-V Theory 3-1

3.1.1 Calculation of Direct Cost 3-2

3.1.2 Calculation of Indirect Costs 3-3

3.1.3 Levelized Fuel Cycle Cost 3-9

3.2 Discount Cash Flow Theory 3-10

3.2.1 Deductible Direct Costs 3-12

3.2.2 Profitable Sales Other Than Energy 3-14

3.3 Use of FUELCOST-V 3-15

4.0 DEFINITION OF REACTOR/FUEL CYCLE SYSTEMS 4-1

4.1 Pressurized Water Reactor (PWR) 4-4

4.2 High Temperature Gas-Cooled Reactor (HTGR)

4.3 CANDU-type Heavy Water Reactor (CANDU) 4-11

4.4 Liquid Metal Fast Breeder Reactor (LMFBR) 4-15

4.5 Gas-Cooled Fast Breeder Reactor (GCFR) 4-20 
NUS-3190

TABLE OF CONTENTS

(Contents)

$\underline{\text { Section and Title }}$

Page No.

5.0 TREATMENT OF BRED FUEL VALUE

5- 1

5.1 Bred Fuel Value in Fuel Cycle Costs 5-3

5.2 Bred Fuel Scenarios for PWR and HTGR 5-5

5.3 Bred Fuel Scenarios for LMFBR and GCFR 5-7

6.0 ASSUMPTIONS AND GROUNDRULES 6-1

6.1 Fuel Cycle Unit Prices 6-1

6.2 Bred Fuel Values 6-7

6.3 Reactor Start Dates and Plant Capacity Factor 6-7

6.4 Fuel Cycle Lead and Lag Times 6-9

6.5 Discount and Interest Rates 6-18

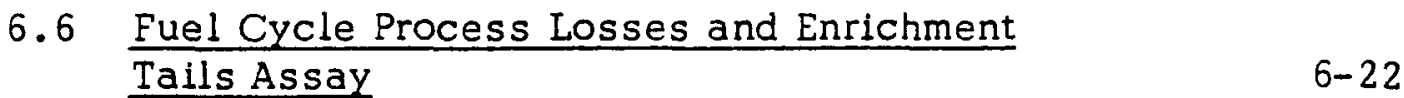

7.0 FUEL CYCLE COST RESULTS $7-1$

7.1 Overview of Fuel Cost Results 7-2

7.2 Fuel Cost Results by Reactor Type 7-12

7.3 Effects of Study Period on Fuel Cost $7-19$

8.0 SENSITIVITY ANALYSIS

8.1 Sensitivity of $\mathrm{U}_{3} \stackrel{\mathrm{O}}{8}_{8}$ Cost 8-2

8.2 Sensitivity of Enrichment Cost 8-22

8.3 Sensitivity of Bred Fuel Value 8-37

8.4 Sensitivity of On-Site Storage Time 8-43

8.5 Sensitivity of Capacity Factor $\quad 8-45$

8.6 Sensitivity of Fabrication Cost 8-59

8.7 Sensitivity of Back-End Cost 8-62 


\section{NUS -3190 \\ TABLE OF CONTENTS \\ (Continued)}

$\underline{\text { Section and Title }}$

9.0 REFERENCES
Page No.

$9-1$

\section{APPENDICES}

APPENDIX A - COORDINATION OF FUELCOST-V DATA WITH NASAP MODELS

$A-1$

APPENDIX B - DETAILED FUEL COST INPUT AND OUTPUT DATA

B-1 
$\underline{\text { Section and Title }}$

LIST OF TABLES

1.0 INTRODUCTION

2.0 SUMMARY

2.1 Effects of Escalation

2.2 Effects of Startup Date

2.3 CANDU-Thorium System

3.0 EFFECTS OF ESCALATION

3.1 Fuel Cycle Unit Prices

3.2 Discount Rates

3.3 Fuel Cost Effects of Escalation

4.0 EFFECTS OF STARTUP DATE

5.1 Fuel Cycle Assumptions

5.2 Resultant Fuel Cycle Costs

6.0 REFERENCES
5.0 CANDU-THORIUM SYSTEM

Page No.

iv

$1-1$

$2-1$

$2-1$

$2-4$

$2-5$

$3-1$

$3-1$

$3-3$

$3-5$

$4-1$

$5-1$

$5-1$

$5-3$

$6-1$

APPENDICES

APPENDIX A ESCALATED FUEL COST INPUT AND OUTPUT DATA

$A-1$

APPENDIX B

FUEL COST INPUT AND OUTPUT DATA FOR 2001 STARTUP
B-1 


\section{APPENDIX B}

Table of Contents for NUS -3237 


\section{NUS-3237 \\ TABLE OF CONTENTS}

Section and Title

Page

PROPRIETARY INFORMATION NOTICE

ii

LIST OF FIGURES

iv

I. INTRODUCTION AND SUMMARY

1

II. ATTRIBUTES DESIRED OF A MASS-FLOW GENERATOR

III. ALTERNATE APPROACHES FOR OBTAINING MASS-FLOW 6 DATA

IV. RECOMMENDATIONS FOR OBTAINING FUTURE MASS-FLOW DATA FOR FUTURE EEDB UPDATES

V. REFERENCES 


\begin{abstract}
APPENDIX C
Table of Contents for NUS-3196

Table of Contents for NUS-3198

Table of Contents for NUS-3199

Table of Contents for NUS -3203

Table of Contents for NUS-3204

Table of Contents for NUS-3207

Table of Contents for NUS-3209

Table of Contents for NUS-3224

Table of Contents for NUS-3242
\end{abstract}




\section{NUS-3196 \\ TABLE OF CONTENTS}

$\underline{\text { Section and Title }}$

PROPRIETARY INFORMATION NOTICE

IIST OF TABLES

iii

LIST OF FIGURES

iv

I. INTRODUCTION AND SUMMARY

II. THE ENRICHMENT PROCESSES

III. COST PER SWU

19

IV. COST ACCOUNT SUMMARY

V. REFERENCES 
NUS-3198

TABLE OF CONTENTS

Section and Title

Page No.

PROPRIETARY INFORMATION NOTICE

ii

I. INTRODUCTION AND SUMMARY 1

II. CONVERSION TECHNOLOGY 3

III. CONVERSION COSTS $\quad 5$

IV. COST ACCOUNT FOR CONVERSION SERVICES

V. REFERENCES 7 


\section{NUS-3199 \\ TABLE OF CONTENTS}

Section and Title

Page No.

PROPRIETARY INFORMATION NOTICE

ii

LIST OF TABLES

iv

I. INTRODUCTION AND SUMMARY 1

II. HEAVY WATER PRODUCTION AND REQUIREMENTS 3

$\begin{array}{ll}\text { III. COST } & 6\end{array}$

IV. REFERENCES 9

C-3 
NUS-3 3203

TABLE OF CONTENTS

$\underline{\text { Section and Title }}$

Page No.

LIST OF TABLES

iv

I. INTRODUCTION AND SUMMARY

I- 1

II .

TECHNICAL MODELS

II-I

A.

LWR Spent Fuel Disposition

II-1

B.

HWR Spent Fuel Disposition

II-8

C.

Reprocessing Waste Transportation and Disposal

II -11

III .

COST MODELS

III-1

A.

LWR Spent Fuel Disposition

III-1

B.

HWR Spent Fuel Disposition

III -29

C.

Reprocessing Waste Transportation and Disposal

III-3I

IV.

COST ACCOUNT SUMMARY

IV- I

A.

LWR Spent Fuel Disposition

IV -1

B.

HWR Spent Fuel Disposition

IV -1

C.

Reprocessing Waste Transportation and Disposal

IV -1

V.

REFERENCES

$\mathrm{V}-1$ 
$\underline{\text { Section and Title }}$

PROPRIETARY INFORMATION NOTICE

LIST OF TABLES

I. INTRODUCTION AND SUMMARY

II. SHIPPING TECHNOLOGY

III. SHIPPING COST

IV. COST ACCOUNT SUMMARY

V. REF ERENCES
Page No.

ii

iv

1

5

10

18

20 
NUS-3207

TABLE OF CONTENTS

Section and Title

Page No.

LIST OF TABLES

IV

I.

INTRODUCTION AND SUMMARY

I-1

II .

TECHNICAL MODELS

II-I

A.

HTGR Throwaway Cycle

II-I

B.

HTGR Spent Fuel Recycle

II -5

III.

COST MODELS

III -1

A.

HTGR Throwaway Cycle

III-1

B.

HTGR Spent Fuel Recycle

III-4

IV .

COST ACCOUNT SUMMARY

IV-1

v.

REFERENCES

$v-1$ 
Section and Title

LIST OF TABLES

LIST OF FIGURES

I .

II .

A.

$B$.

C.

D.

E.

III .

A.

IV .

REFERENCES
Page No.

iv

v

1

7

7

16

23

23

25

28

34

37

61 
NUS-3 224

TABLE OF CONTENTS

Section No. and Titie

Page No.

LIST OF TABLES

iv

LIST OF FIGURES

iv

I.

INTRODUCTION AND SUMMARY

I-I

II. SPENT FUEL REPROCESSING

II- I

A. Background

II -1

B. Process Technology

II -2

C. Plant Size and Capacity Factor

II -5

III.

UNIT REPROCESSING COSTS

III-1

A. Capital Cost Estimates

III-1

B. Estimates of Operation and Maintenance Costs

III-5

C. Financial Structure of Industry

III -7

D. Costing Methodology

III-8

E. Resultant Unit Reprocessing Costs

III- I 1

IV . COST ACCOUNT SUMMARY

IV -1

V.

REFEREN CES

V-1

C-8 


\section{APPENDIX D}

Table of Contents for NUS-3243 
Section and Title

Page

PROPRIETARY INFORMATION NOTICE

ii

LIST OF TABLES

iv

LIST OF FIGURES

$\mathrm{v}$

I. INTRODUCTION AND SUMMARY

II. NUCLEAR FUEL UNIT-COST COMPONENTS

III. RECOMMENDATIONS FOR FUTURE WORK

$\underline{\mathrm{U}}_{3} \mathrm{O}_{8}$ Unit-Costs

$\underline{U F}_{6}$ Conversion Unit-Costs

Enrichment Unit-Costs

Fabrication Unit-Costs

Shipping Unit-Costs

Reprocessing Unit-Costs

10

Disposal (and Storage) Unit-Costs

IV. REFERENCES 


\section{APPENDIX E}

Table of Contents for NUS-3223 
NUS-3 223

TABLE OF CONTENTS

Section and Title

Page

PROPRIETARY INFORMATION NOTICE

LIST OF TABLES

iv

I. INTRODUCTION 1

II. PRESENTATION OF RESULTS 3

A. Plant Data 3

B. Fuel Cost Data 8

III. FUTURE FUEL COST TRACKING EFFORTS 19

$\begin{array}{ll}\text { IV. REFERENCES } & 20\end{array}$

APPENDIX A FPC GUIDELINES FOR CLASSIFYING A-1 O\&M EXPENSES 
APPENDIX C-1 


\section{APPENDIX C-1}

\section{INFIATION-FREE FIXED CHARGE RATES}

\section{C1. 1 GENERAL}

This discussion introduces the concepts involved and addresses methods of calculation of fixed charges applicable to investor-owned utilities, as used in the Energy Economic Data Base.

For every investment made in a capital asset, the owner company commits itself to a program of payments over the life of that asset. These payments, or charges against income which the company expects to realize from its investment, are generally fixed in nature, related only to the actual initial investment, and independent of the actual usage of the asset. Such payments are commonly called fixed charges (also referred to as annual or carrying charges) and represent the absolute minimum revenue requirements which the investment must command.

Because the investment in plant is recovered over its life by periodic depreciation or amortization charges, the net investment declines and consequently the fixed charges, as a percent of initial investment, vary from year to year. Therefore, it is convenient to know a "levelized" fixed charge value, which will incorporate not only the actual year by year values of fixed charges, but also the time variance in payments. This levelized annual value (or uniform annual equivalent) permits the engineer to make economic comparisons of alternative investment plans which may have quite different time schedules of fixed charge payments.

The levelized annual value is calculated as a weighted average of the actual year by year values. The weighting factors represent the time value of money and are called present-worth factors. The single payment present-worth factor 
is calculated from the expression $\frac{1}{(1+R)^{n}}$ where " $R$ " is the cost of money or rate of return per time interval expressed as a decimal, and " $n$ " is the number of time periods. To illustrate the concept, it is necessary to consider the total assets of the company as a bank or pool of money, where money borrowed is charged interest or money deposited in advance earns interest. Under this arrangement, consider the present worth of $\$ 100$ spent " $n$ " years from now, where the cost of money is 5.42 percent per year:

\begin{tabular}{|c|c|c|c|}
\hline$\underline{\underline{n}}$ & $\begin{array}{c}\text { Present } \\
\text { Worth Factor } \\
\end{array}$ & s Spent & $\begin{array}{l}\text { Present Worth } \\
\text { of } \$ \text { Spent }\end{array}$ \\
\hline 0 & $\frac{1}{(1+.0542)^{c}}$ & 100 & $\$ 100.00$ \\
\hline 1 & $\frac{1}{(1+.0542)^{I}}$ & 100 & $\$ 94.86$ \\
\hline 5 & $\frac{1}{(1+.0542)^{5}}$ & 100 & $\$ 76.81$ \\
\hline
\end{tabular}

The table gives substance to the intuitive belief that a plan involving an expenditure in the future is less costly than one which requires the same amount of money to be spent earlier. In the example, $\$ 76.81$ now in hand and earning 5.42 percent interest will support a $\$ 100$ expenditure to be made five years from now, whereas the same $\$ 100$ spent one year from now has the higher present value of $\$ 94.86$.

The fixed charges on investment plus the fuel cycle and operating and maintenance costs represent the total revenue requirements needed to support the project. Therefore, these revenue requirements can be used for economic comparisons of alternative investment plans. The plan having the smallest revenue requirement yields the lowest costs to the consumer or, where income is fixed, the greatest net return for the company. 
Fixed charges include the following basic items:

1. Return on Investment and/or the cost of borrowed money

2. Depreciation, amortization or repayment of principal

3. Taxes on Income

4. State and Loca1 Taxes

5. Insurance

6. Interim replacements

Since the components of fixed charges are all related to the initial investment, it is usually more convenient to work with fixed charge rates rather than actual dollars. The levelized annual rate, consisting of the summation of levelized annual rates of each of the above components and levelized by present-worth methods, can then be applied to the alternative investments to yield the uniform annual equivalent total fixed charges in dollars.

The concept of capital recovery encompasses the first two components of fixed charges tabulated above, namely return on investment (rate of return) and depreciation (retirement of principal). The capital recovery rate is a levelized annual charge and is a function of the overall rate of return and the life of the asset (book life for accounting purposes). The capital recovery factor is calculated from the expression $\frac{R(1+R)^{n}}{(1+R)^{n}-1}$ where " $R^{\prime \prime}$ is the rate of return expressed as a decimal and " $n$ " is the life of the asset in years. Capital recovery factors are tabulated in many interest tables. This factor gives the annual charge which would pay all cost of money and fully recover the invested capital over the life of the asset in equal payments. Again using the money pool concept, any schedule of payments which accomplishes the same results over the same period will have the same 
present-worth as the uniform annual payment schedule. For instance, the capital recovery factor for 5.42 percent and 30 years is 0.0682 . This means that a payment of $\$ 6.82$ per $\$ 100$ of investment, made each year for 30 years, would fully support return plus depreciation.

Now for the same case, consider paying interest on the full investment each year, and putting an amount into the interest-bearing money pool such that at the end of 30 years we could withdraw $\$ 100$ to retire the principal. That annual deposit can be calculated from the expression $\frac{R}{(1+R)^{n}-1}$ which is called a sinking fund factor. For our example, it comes out to be 0.014 or $\$ 1.40$ per $\$ 100$ of investment. Therefore, the total $\$ 6.82$ annual capital recovery can be considered to consist of:

\section{Formation of Annual Capital Recovery}

$\begin{array}{ll}\$ 5.42 & \text { Return at } 5.42 \% \\ +\underline{1.40} & \text { Sinking Fund Depreciation } \\ \$ 6.82 & \text { Annual Capital Recovery }\end{array}$

On the other hand, we may choose to retire the $\$ 100$ principal in 30 equal annual installments of $\$ 3.33$, which represents a straight line depreciation rate of 3.33 percent $\left(\frac{1}{n}=\frac{1}{30}=0.033\right)$. It is now necessary to pay interest or return on only the net investment (outstanding balance). The interest payments therefore decrease annually as shown below:

Decrease in Interest Payments

$\begin{array}{ccc}\text { Year } & \text { Net Investment } & \text { Interest at } 5.42 \% \\ 1 & \$ 100.00 & \$ 5.42 \\ 10 & 70.00 & 3.79 \\ 20 & 36.67 & 1.99 \\ 30 & 3.33 & 0.18 \\ & \mathrm{C}-1-4 & \end{array}$


If we compute the present-worth of all interest payments over the full 30 years, and then the uniform annual interest, the levelized payment is $\$ 3.49$. Therefore, the $\$ 6.82$ annual capital recovery can be considered to consist of:

Formation of Annual Capital Recovery

$\$ 3.49$ Levelized Return at $3.49 \%$

$+\underline{3.33}$ Straight Line Depreciation

$\$ 6.82$ Annual Capital Recovery

However, the more common presentation is in the former format (i.e., return plus sinking fund depreciation).

In summary, it can be demonstrated that any pay-back schedule results in the same levelized annual total for return plus depreciation which is readily found by using the capital recovery factor.

The various components of fixed charges as they apply to private (investorowned) utilities, are discussed in section C1.2.

\section{C1.2 INVESTOR-OWNED UTILITIES}

\section{C1.2.1 Return on Investment}

The overall rate of return is the average cost of money to the utility and is a composite of interest on debt and earnings for equity. Debt money comes from bondholders, while equity money is supplied by the stockholder. For a particular project, the economic analysis must be based on the average capital structure of the company, since in actual operation the investment under study will become just a part of total investment in the business. 
For investor-owned utilities a 50/50 debt-equity ratio is not uncomon, and the range of $40 / 60$ to $60 / 40$ includes most companies. Most indentures of trust limit the debt to not more than $2 / 3$ of added property. In some states, the percentage of total capital raised by debt is limited by law. State and Federal Regulatory Commissions also have some control.

Having established the debt-equity ratio, the interest or earnings on each component must be determined. Here the bond interest rate, to be used in studies, must be that which would have to be paid for new bonds, not an average of all outstanding debt which might be considerably lower. The interest rate must also be commensurate with risk. A company with traditionally high debt financing will require the bondholders to incur higher risk, and they in turn will command higher rates. Equity earnings must also reflect the risk involved, and must be in proper perspective to debt interest. The overall return, illustrated in the example below, must also be evaluated for its reasonableness. In practice, return of the regulated electric utility industry is controlled within rather close limits, generally falling within the range of approximately five percent on an inflation-free basis. EXAMPLE OF OVERALL RATE OF RETURN IN AN INFLATION-FREE SCENARIO Interest or Financial Structure

$51.4 \%$ Bonds 48.6\% Common Stock @ Earnings Rate

$3.93 \%=$

$7.00 \%=$

Total:
Weighted Rate of Return 0.0202 Debt $\underline{0.0340}$ Equity 0.0542 or $5.42 \%$ 
The financial structure and bond and equity rates of return used in this diacussion are based upon information reported in DOE/EIA-0044 (Apri1 1978), "Statistics of Privately Owned Electric Utilities in the United States in 1976 (Class A and B Companies)", as cited in the NUS Corporation Report NUS-3190, "Fuel Cycle Cost Estimates for LWR, HTGR, CANDU - Type HWR, LMFBR and GCFR." The inflated rates from these documents, 6.93 percent and 10 percent for bonds and equity respectively, were deflated by three percent to obtain the inflation-free rates used in this example.

Several economic indicators were used to measure the past effects of inflation and develop the average deflator of three percent per year. These indicators and their sources are cited in NUS -3190 as follows:

1. Consumer-Price Index (CPI) - As reported in "Consumer Price Index for All Urban Consumers (Revised CPI-U), U.S. City Average, U.S. Department of Labor, Bureau of Labor Statistics."

2. Gross National Product (GNP) Deflator - Based upon private communication with the Bureau of Economic Analysis, U.S. Department of Commerce.

3. Wholesale Price Index for Industrial Commodities (WPI) - Based upon private communication with Bureau of Labor Statistics, U.S. Department of Labor.

\section{C1.2.2 Depreciation}

Depreciation or amortization represents retirement of principal. For book purposes (plant valuation) property is depreciated linearly over its book 1ife. This straight line method can be represented by an annual charge at the rate of $\frac{1}{n}$ as discussed earlier, or in levelized form by the appropriate sinking fund factor. The life selected should be the best estimate of life expectancy considering both physical deterioration and economic obsolescence factors. Commonly used lives of nuclear and fossil power generating stations 
are approximately 30 years. In comparison, hydroelectric installations are often assigned lives of 40 to 50 years or more.

Some components of the total investment cost of a generating station are for non-depreciable property, the prime example of which is land. In some very detailed economic studies, the cost of land and other non-depreciable components of capital investment, such as materials and supplies and working capital, are segregated. When this is done, a different fixed charge rate is applied to the non-depreciable assets, which does not include depreciation and hence does not decline with time. However, in many economic studies this distinction is not made, and the resulting error is not significant unless the non-depreciable components are responsible for an unusually high percentage of the total capital cost.

\section{C1.2.3 Taxes on Income}

of the revenue required to cover fixed charges, all components except equity earnings are expense items which are deductible from gross income for income tax purposes. However, to any requirement of revenue for equity earnings must also be added the necessary revenue to pay the income tax. For example, at the present corporate federal income tax rate of 48 percent it would take $\$ 100$ in gross revenue to net $\$ 52$ of equity return. Each year federal income tax liability declines with net investment. The levelized annual income tax rate can be calculated from the fraction of levelized return that is equity earnings, as shown below in an example using previously cited sample data. 
Example of Calculation of Levelized Annual Income Tax ( $t)$

$$
\bar{t}=\left(\frac{T}{(1-T)}\right) \quad\left(\mathrm{CRF}-\frac{1}{n}\right) \quad\left(\frac{\mathrm{R}-\mathrm{bi}}{\mathrm{R}}\right)
$$

where: $\mathrm{T}=$ federal income tax rate of $48 \%$

$$
\begin{aligned}
& \left(\mathrm{CRF}-\frac{1}{\mathrm{n}}\right)=\begin{array}{l}
\text { levelized return, computed previously } \\
\text { as the difference between capital }
\end{array} \\
& \text { recovery factor and straight line } \\
& \text { depreciation rate }(6.82 \%-3.33 \%=3.49 \% \\
& \text { for } 5.42 \% \text { return and } 30 \text { year life). } \\
& \left(\frac{R-b i}{R}\right)=\begin{array}{l}
\text { the fraction of levelized return which } \\
\text { is equity earnings. }
\end{array} \\
& \mathrm{R} \text { is overall return of } 5.42 \% \\
& b \text { is bond ratio of } 51.4 \% \\
& i \text { is bond interest of } 3.93 \% \\
& \text { Levelized income } \operatorname{tax}(\bar{t})=\left(\frac{0.48}{0.52}\right) \quad(0.0349)\left(\frac{0.0542-0.0202}{0.0542}\right)=2.02 \%
\end{aligned}
$$

State income taxes can generally be handled in a similar fashion, as can other taxes on income. Calculations often can be simplified by working with a composite tax rate which is the sum of federal plus state plus other income tax rates. In this study, however, "Taxes on Income" are restricted to federal taxes only.

While the utility industry almost universally uses the straight-line method for book depreciation, liberalized or accelerated depreciation methods are commonly used for tax purposes. These methods do not reduce the total tax dollars paid over the life of the asset, but they do lead to reduction of the levelized annual tax charge by deferring some of the taxes in the early years to later payments. There are two commonly used methods of calculating 
accelerated tax depreciation. They are the Sum-of-Years-Digits (SYD) method and the Double-Rate-Declining-Balance (DRDB or DDB) method.

With SYD, the annual tax depreciation rate is a fraction whose denominator is the sumnation of all the numbers from one to end of plant life in years. The numerators decrease from end of plant life in years to one. For 30 years, $\sum_{n=1}^{30} n=465$. Therefore, the first year depreciation rate is $\frac{30}{465}$, second year $\frac{29}{465} \ldots$ decreasing to $\frac{1}{465}$ in the last year. It is obvious that:

$$
\frac{30}{465}+\frac{29}{465}+\frac{28}{465} \cdot \cdot \frac{3}{465}+\frac{2}{465}+\frac{1}{465}=100 \%
$$

Double declining balance tax depreciation is calculated each year as twice the straight line rate times net investment. For example, for 30 year life, the normal straight line rate is $\frac{1}{30}=3.33$ percent and the DDB rate is 6.67 percent. The computation procedure is as follows:

\section{Annual DDB Tax Depreciation}

$\begin{array}{ccc}\text { Year } & \text { Net Investment }(\%) & \text { DDB Depreciation (\%) } \\ 1 & 100.00 & 6.67 \\ 2 & 93.33 & 6.23 \\ 3 & 87.10 & 5.81 \\ 4 & 81.29 & 5.42\end{array}$

If this computation were continued for 30 years, the summation of annual depreciation entries in the DDB column will not yield 1.00 or 100 percent. It is therefore necessary to switch to the straight line method about halfway through plant life. 
There are rather complex formulae for computing the levelized annual value of accelerated depreciation. These are presented in the sample calculations at the end of this discussion in Section C1.3. Also given is a formula, which is used to levelize income tax using previously calculated levelized accelerated depreciation. The tax formula reflects the fact that the tax savings attributable to accelerated depreciation is $\frac{T}{I-T}$ times the difference between straight line and the levelized annual tax depreciation used.

The federal investment tax credit (10 percent of qualified investment deductible from income tax in the first year only) also produces a small reduction in the levelized income tax charge. This reduction is calculated as the annual capital recovery of the present worth of the 10 percent credit in year one, and is calculated to be 0.0048 or 0.48 percent as shown in Section c1.3.4.

Calculation of fixed charges on a flow-through basis (benefits passed on to consumers), incorporating liberalized tax depreciation and the 10 percent credit as used by most companies, yields minimum revenue requirements since the income tax component is reduced.

\section{C1.2.4 State and Local Taxes}

There are a variety of other types of taxation which are encountered in the investor-owned utilities industry. The more important ones are property, franchise and gross revenue taxes. Property taxes are levied by the local community, and the rate is applied to the original (undepreciated) value of the asset. 
In several of the states where the franchise tax is paid, the levy is on net income. Therefore, it is treated as a state income tax, which has been discussed previously.

The gross revenue or gross receipts tax, on the other hand, is levied on all revenue which the utility collects without deductions or exemptions. The tax then is a revenue requirement in itself, and when used must be added to the subtotal of all other fixed charges. It must be noted that unlike other types of taxation, the gross receipts tax revenue requirement must also be added to operation and maintenance and fuel expenses in economic studies. However, since in comparison of alternatives, the effect of a gross revenue tax is to increase the differential costs between alternatives by the tax rate percentage, it is sometimes handled in that way, instead of carrying it through individual alternative fixed charge rate and operating expense calculations.

The fixed charge rate of 2.55 percent for state and local taxes, shown in Section C1.2.8, is based upon information reported in DOE/EIA-0044, as cited in NUREG-0480, "Coal and Nuclear: A Comparison of the Cost of Generating Baseload Electricity by Region." It is an average for the years 1972 through 1976 (the last five years of published data), and does not reflect the effects of general inflation over the life of the plant.

\section{C1.2.5 Insurance}

Insurance coverage for power plants include both property damage and public liability. Liability coverage is not directly related to plant investment and is therefore included in $O \& M$ costs. The fixed charge rate of 0.06 percent for property damage, shown in Section C1.2.8, is based upon data reported 
in DOE/EIA-0044, as cited in NUREG-0480. It is an average of the ratios of the property insurance paid by privately-owned utilities to their total investment in plant and equipment, for the years 1972 through 1976.

Annual charges for insurance usually amount to less than one percent of the capital investment, and in some cases are even considered negligible in developing the total fixed charge rate.

\section{C1.2.6 Interim Replacements}

Some utilities include a rate for interim replacements in their fixed charges. The charges represent large expenditures for replacing major equipment components of the asset during its life, where failure of such components would impair the integrity of the asset. Interim replacement charges, as used here, do not include normal maintenance costs or cost of additions made after the original construction. When used, the most commonly applied rate is 0.35 percent annually, which is based upon fossil-fueled power station experience. Long term experience upon which to base the value of this allowance for nuclear plants is lacking. However, it is believed that the 0.35 percent value is conservative for them, since safety-related nuclear components are subject to more stringent design specifications and quality control inspections. The fixed charge rate of 0.35 percent for interim replacements, shown in Section $\mathrm{C} 1.2 .8$, does not reflect the effects of general inflation over the life of the plant. 


\section{C1.2.7 Discount Rate}

The fixed charge rate developed in the preceding sections reflects the leve1ized value of revenue requirements for capital investment over the life of the plant. The cost levelization involves the process of present worthing or discounting and was performed using a discount rate expression, which relates the fractions of debt and equity capital and their interest rates as follows:

$$
\text { Where: } \begin{aligned}
\mathrm{x}_{1} & =\mathrm{bi}(1-\mathrm{b}) \mathrm{j} \\
\mathrm{x}_{1} & =\text { discount } \text { Rate } \\
\mathrm{b} & =\text { debt capita1 } \\
(1-\mathrm{b}) & =\text { equity capita1 } \\
\mathrm{i} & =\text { interest rate on debt capital } \\
\mathrm{j} & =\text { interest rate on equity capital }
\end{aligned}
$$

For this case, the discount rate is equal to the rate of return of 5.42 percent. This is the classical way that many utilities use to develop fixed charge rates.

However, and with increasing frequency, a significant number of utilities are using an effective discount rate for the levelization process. This effective discount rate takes into consideration the deductibility of interest expense on bonds, so that a dollar of bond interest requires less revenue than a dollar of equity return. It is calculated from the expression

$$
\mathrm{x}_{1}=(1-\mathrm{T})(\mathrm{bi})+(1-\mathrm{b}) \mathrm{j}
$$

Where: $T$ is the income tax rate

It appears to be a matter of utility preference as to which approach is used. 


\section{C1.2.8 Typical Inflation-Free Fixed Charges for Investor-Owned Utility Nuclear and Fossil Power Generating Stations}

The fixed charge rate developed for the Energy Economic Data Base Cost Summary has the value of 10.56 percent for privately owned utilities operating in the service area containing the "Middletown Site". This value is subject to variations depending upon utility type, station type and station location.

The levelized 10.56 percent inflation-free rate is composed of the following components :

\section{EEDB Fixed Charge Rate}

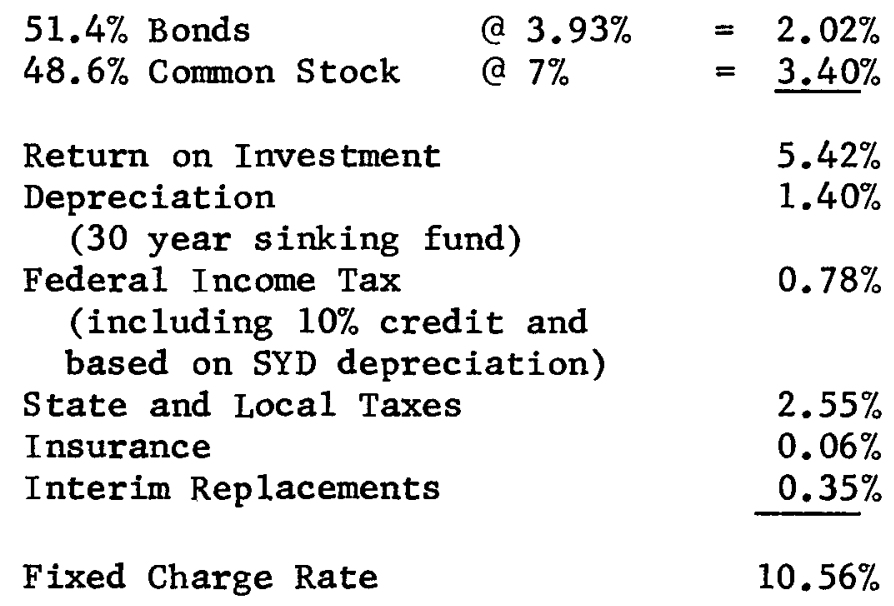


C1.3 FORMUIAE AND SAMPLE CALCUIATIONS FOR LEVELIZED VALUES OF ACCELERATED TAX DEPRECIATION AND FEDERAL INCOME TAX

A11 sample calculations are based on the following parameters:

$5.42 \%$ Return on Investment $\quad(R=0.0542)$

51.4/48.6 Debt/Equity Ratio $(b=0.514) \quad$ (Debt/Capital Structure

$3.93 \%$ Bond Interest

$(i=0.0393)$

30-Year Life

$(n=30)$

C1.3.1 Double Declining Balance (DDB) Depreciation Method

$\bar{D}=S F F \quad\left[\frac{\frac{2}{n}(C A F)+R\left(1-\frac{2}{n}\right)^{n}}{R+2 / n}\right]$

Where: $\overline{\mathrm{D}}=$ Levelized Annual Depreciation

$\mathrm{SFF}=$ Sinking Fund Factor $(\mathrm{SFF}=0.014)$

$\mathrm{n}=$ Life $(\mathrm{n}=30)$

$\mathrm{CAF}=$ Single Payment Compound Amount Factor $(\mathrm{CAF}=4.87)$

$\mathrm{R} \quad=$ Rate of Return $(\mathrm{R}=0.0542)$

Sample calculation:

$\overline{\mathrm{D}}=0.014\left[\frac{\frac{2}{30}(4.87)+0.0542\left(1-\frac{2}{30}\right)^{30}}{0.0542+2 / 30}\right]=3.84 \%$ 
C1.3.2 Sum of Years Digits (SYD) Depreciation Method

$$
\begin{aligned}
& \bar{D}=\frac{2\left(\mathrm{CRF}-\frac{1}{n}\right)}{R(n+1)} \\
& \text { Where: } \bar{D}=\text { Levelized Annual Depreciation } \\
& \mathrm{CRF}=\text { Capital Recovery Factor }(C R F=0.682) \\
& \mathrm{n}=\text { Life }(\mathrm{n}=30) \\
& \mathrm{R}=\text { Rate of Return }(\mathrm{R}=.0542)
\end{aligned}
$$

Sample calculation:

$$
\overline{\mathrm{D}}=\frac{2\left|0.682-\frac{1}{30}\right|}{0.0542(30+1)}=4.15 \%
$$

\section{C1.3.3 Federal Income Tax}

$$
\bar{t}=\frac{T}{1-T}\left[R-d-\frac{b i}{R}\left(R-d_{o}\right)\right]
$$

$$
\text { Where: } \begin{aligned}
& \overline{\mathrm{t}}=\text { Levelized Annual Federal Income Tax } \\
& \mathrm{T}=\text { Federal Income Tax Rate }(\mathrm{T}=0.48) \\
& \mathrm{R}=\text { Rate of Return }(\mathrm{R}=0.0542) \\
& \mathrm{d}= \overline{\mathrm{D}}-\mathrm{SFF} \text { or Difference between levelized depreciation } \\
& \text { for a particular method and sinking fund depreciation } \\
& \mathrm{b}= \text { Bond Ratio }(\mathrm{b}=.514) \\
& \mathrm{i}= \text { Bond Interest Rate }(\mathrm{i}=.0393) \\
& \mathrm{d}_{\mathrm{o}}= \frac{1}{\mathrm{n}}-\mathrm{SFF} \text { or Difference between straight line } \\
& \text { and sinking fund depreciation }
\end{aligned}
$$




\section{Sample calculations:}

1. With straight line tax depreciation (not accelerated)

$$
\begin{aligned}
& \mathrm{d}=\mathrm{d}_{\mathrm{o}}=\frac{1}{\mathrm{n}}-\mathrm{SFF}=\frac{1}{30}-0.014=0.0193 \\
& \overline{\mathrm{t}}=\frac{0.48}{1-0.48}\left[0.0542-0.0193-\frac{(0.514)(0.0393)}{0.0542}(0.0542-0.0193)\right]=2.02 \%
\end{aligned}
$$

2. With double declining balance tax depreciation

$$
\begin{aligned}
& \mathrm{d}=\overline{\mathrm{D}}-\mathrm{SFF}=0.0384-0.014=0.0244 \\
& \mathrm{~d}_{\mathrm{O}}=\frac{1}{\mathrm{n}}-\mathrm{SFF}=0.0193 \text { as above } \\
& \overline{\mathrm{t}}=\frac{0.48}{1-0.48}\left[0.0542-0.0244-\frac{(0.514)(0.0393)}{0.0542}(0.0542-0.0193)\right]=1.55 \%
\end{aligned}
$$

3. With SYD tax depreciation

$$
\begin{aligned}
& \mathrm{d}=\overline{\mathrm{D}}-\mathrm{SFF}=0.0415-0.014=0.0275 \\
& \mathrm{~d}_{\mathrm{O}}=\frac{1}{\mathrm{n}}-\mathrm{SFF}=0.0193 \text { as above } \\
& \overline{\mathrm{t}}=\frac{0.48}{1-0.48}\left[0.0542-0.0275-\frac{(0.514)(0.0393)}{0.0542}(0.0542-0.0193)\right]=1.26 \%
\end{aligned}
$$




$$
\begin{aligned}
& \bar{t}_{c}=0.10\left(\mathrm{PWF}_{1}\right)(\mathrm{CRF})(0.75) \\
& \text { Where: } \bar{t}_{c}=\text { Levelized effect of } 10 \% \text { tax credit in year one } \\
& \mathrm{PWF}_{1} \text { = Single Payment Present-Worth Factor for year one } \\
& \mathrm{CRF}=\text { Capital Recovery Factor } \\
& 0.75=\text { Portion of investment qualified for investment tax credit } \\
& \bar{t}_{c}=0.10 \frac{1}{1.0542}(0.0682)(0.75)=0.48 \%
\end{aligned}
$$

\section{C1.3.5 Summary of Sample Calculations}

Tax Depreciation Method

Levelized Annua1 Depreciation in Percent

$$
\overline{\mathrm{D}}
$$

$$
3.33
$$

3.84

Double Declining Balance

Sum of Years Digits
Levelized Annual Federa1 Income Tax in Percent $10 \%$ Credit in Tax Year 1-Levelized Net Tax

$\begin{array}{ccc}\bar{t} & \bar{t}_{c} & \bar{t}-\bar{t}_{c}\end{array}$

2.02

0.48

1.54

\subsection{5}

0.48

1.07

1.55

0.48

0.78 
APPENDIX C-2 


\section{APPENDIX C-2}

\section{ENERGY ECONOMIC DATA BASE (EEDB)}

\section{CAPITAL COST UPDATE PROCEDURE}

\section{C2.1 INTRODUCTION}

The Advanced Engineering Department of United Engineers \& Constructors Inc. plans to continue to update the EEDB on a yearly basis through FY1980 as a minimum, and on a semi-basis when necessary, under their contract with DOE. Generally, capital cost drivers do not advance or retreat at rates that cause bottom line cost changes to accumulate to significant levels in periods less than one year. When such cost changes do occur, they are evaluated for their significance, and updates issued at intervals less than one year, if required.

Each plant model update consists of review and revision of its capital, fuel cycle and operating and maintenance costs in accordance with the EEDB update procedures. This appendix describes the capital cost update procedures only, since the fuel and $O \& M$ costs are included in the EEDB as developed. Updates of fuel and O\&M costs, and the development of procedures for accomplishing them, are planned during FY79.

Capital cost updates are performed at two levels:

a. incorporation of cost changes caused by the passage of time (inflation) to the new EEDB effective date, and by changes in labor productivity

b. incorporation of cost changes caused by design changes initiated by advances in the state-of-the-art, modifications of industry practice, promulgation of regulations and proliferation of codes and standards

A11 plant models are revised at level "a" during each capital cost update, and models for which design changes are identified are concurrently revised at level "b". During any EEDB update, models may be deleted and new models added, depending on the evaluation requirements of DOE. 


\section{C2.2 EEDB CAPITAL COST UPDATE PROCEDURE}

Capital cost updates are done in two parts. First the plant technical models are updated for necessary design changes. Then, the updated technical models are used to update the capital cost models for incorporation of cost changes.

\section{C2.2.1 Preparation for Technical Mode1 Update}

The first step in the technical model update is the review of pertinent information sources, to identify the following for each plant model in the EEDB:
a. advances in the state-of-the-art
b. modifications of industry practices
c. new and revised regulations
d. new and revised codes and standards

Each of the four reviews is performed under the supervision of the EEDB Program Project Manager. Reviews of advances in the state-of-the-art and modifications of industry practices are performed with the assistance of the Lead Technical Engineer for each of the various plant models in the EEDB. Resource data for these reviews are drawn from currently active UE\&C power plant projects. Reviews of regulations and codes and standards are performed with the assistance of the Manager of Licensing and the Senior Consultant on Codes and Standards. Resource data for these reviews are drawn from the UE\&C document "A Compilation of Federal Regulations for the Design and Licensing of Power Plants Including Engineering Guidelines for Their Implementation," the American Nuclear Society (ANS) Nuclear Power Plant Standards Committee (NUPPSCO), the American Society of Mechanical Engineers (ASME) Boiler and Pressure Vessel Code (B\&PVC) and the Institute of Electrical and Electronics Engineers (IEEE) Nuclear Power Engineering Committee (NPEC). 
The reviewers determine which technical models require design changes, and what the changes must consist of, to upgrade them to reflect current technology. Once this is done, technical models are revised where required by the Lead Technical Engineers with the assistance of the Structural, Nuclear, Mechanical, Chemical, Electrical, Instrumentation and Control, Heating, Ventilating and Air Conditioning, and Piping Design Engineers.

\section{C2.2.2 Technical Model Updates}

Following the above preparatory steps, the Technical Model updates are performed in the following sequential steps:

a. Lead Technical Engineers, under the supervision of the EEDB Program Project Manager, identify design changes necessary in the Base Technical Models to reflect current design practices and/or to comply with current regulatory requirements, based upon the reviews described above.

b. Design Engineers, under the supervision of the Lead Technical Engineers, then modify the existing conceptual design, the heat balance diagram, plant layout drawings, equipment arrangement drawings, block flow diagrams, electrical diagrams and minispecifications of the Base Technical Models.

c. Design Engineers, under the supervision of the Lead Technical Engineers and coordinated by the EEDB Program Project Manager, prepare necessary revisions to the existing PEGASUS minispecifications, equipment and commodity quantities and necessary additions or deletions of complete accounts of the Base Technical Models.

\section{C2.2.3 Ground-Rules for Capital Cost Model Update}

Whether or not technical model revisions are required, the major update effort is to develop new commodity and equipment costs and labor manhours for each of the multitude of accounts in all models. The objective is to have the capability to provide an accurate, substantive, detailed cost estimate in a very short time frame. 
Tables C2-1 and C2-2 tabulate installed costs for major groups of plant commodities and equipment and the relation of these costs to total direct plant costs for the PWR (1139 MWe Pressurized Water Reactor NPGS) and the HS8 (794 MWe High Sulfur Coa1-Fired FPGS) Base Data Studies 1isted in Table 1-3. Component costs are grouped in accordance with the method by which costs are developed by PEGASUS. Computer Costed Items, such as cubic yards of concrete and tons of steel, are obtained from published national and/or company indices that are available for direct input into computer data files. Quotation Costed Items are obtained from estimating quotations submitted by vendors and are stored in data files in the computer. Handbook Costed Items are developed from manufacturers' catalogs, apparatus price handbooks or informal sales office estimates and stored in data files in the computer. Generally, costs are not taken from actual purchase order data to preclude the random variations of the marketplace from impacting estimates used in comparing alternatives over long periods of time.

Tables C2-1 and C2-2 reveal that only six of the total items listed for the PWR and HS8 Base Data models comprise 76.4 and 70.0 percent of their total direct plant costs respectively. Of these six, two are automatically costed by the computer from data files of national or company indices. These six items are as follows:
a. Structura1 Commodities
b. Piping and Ductwork
c. Nuclear Steam Supply
d. Turbine-Generator
e. E1ectric Plant
f. Instrumentation and Control

$$
\mathrm{C}-2-4
$$


Therefore, in order to accomplish the stated objective, the following groundrules are established for making cost changes:

a. New components, or those subject to technical change, other than Computer Costed Items, are recosted as Quotation Costed Items or as Handbook Costed Items, as described above.

b. Components not subject to technical change, other than Computer Costed Items, Nuclear Steam Supply or Boiler, Turbine-Generator, Electric Plant and Instrumentation and Control, are escalated per the update ground-rules.

c. New manufacturers estimating quotations are obtained for the Nuclear Steam Supply or Boiler and Turbine-Generator whether or not these items are subject to technical change.

d. The Electric Plant and Instrumentation and Control are recosted from manufacturers' handbooks, catalogs or informal estimates, as required, whether or not these items are subject to technical change.

e. The material and labor rates in the computer data files are updated from national and/or company indices.

During the update, items which are escalated only are spot-checked to determine if the escalated cost deviates unacceptably from an estimating quotation cost. Where such deviations are detected, new estimated costs are substituted for the escalated costs.

\section{C2.2.4 Capital Cost Mode1 Update (Direct Costs)}

Following the above ground-rules, the Capital Cost model updates of direct costs are made as follows, based on either the existing, updated or new technical model:

a. Design Engineers and Cost Estimating Engineers, under the supervision of the Lead Technical Engineers and the coordination of the EEDB Program Project Manager, update:

- the PEGASUS unit cost data files for Computer Costed Items from published national and company indices;

- escalation data, as required; 
- unit cost data for Quotation Costed Items, as required;

o unit cost data for Handbook Costed Items, as required.

b. Cost Estimating Engineers, under the supervision of the Lead Technical Engineers and the coordination of the EEDB Program Project Manager, update the unit field labor manhours, and the unit field material cost based on published national indices and UE\&C project experience.

c. Cost Estimating Engineers, under the supervision of the EEDB Program Project Manager, update:

- the PEGASUS data files for craft labor hours and account crew mixes to establish the new composite labor rates;

- the auxiliary sort code for each account for applying unit pricing and escalation and for obtaining commodity sort printouts.

d. Computer Technicians make a preliminary run of the PEGASUS/CONCICE program to provide data for compiling the indirect costs.

\section{C2.2.5 Capital Cost Model Update (Indirect Costs)}

Capital Cost model updates of indirect costs are made in one step based on the preliminary PEGASUS/CONCICE output.

a. Cost Estimating Engineers and the Engineering Economist, under the supervision of the EEDB Program Project Manager, prepare the inputs for the indirect cost accounts from proprietary relationships established from UE\&C nuclear and fossil plant engineering and construction project experience.

\section{C2.2.6 Updated Technica1 and Capita1 Cost Model Data}

Following the sequences described above, the computer technicians run the full PEGASUS/CONCICE program for each model in the data base and receive: 
a. PEGASUS Equipment List printout which establishes the details of the new or updated Technical Model;

b. CONCICE Capital Cost (Direct plus Indirect) printout which establishes the new or updated Total Base Costs for the Capital Cost Model;

c. CONCICE Commodity List printout which establishes the new or updated lists of commodities and equipment for the new or updated Technical Model. 
ENERGY ECONOMIC DATA BASE

RELATION OF INSTALLED COMPONENT COST TO TOTAL DIRECT PLANT COST

\begin{tabular}{cc}
\multicolumn{2}{c}{ PWR } \\
\hline Cost & $\%$ of Tota1 \\
$\$(106)$ & Plant Cost
\end{tabular}

1. COMPUTER COSTED ITEMS
a. Structural Commodities
b. Piping and Ductwork
c. Lighting and Service Power
d. Land Cost

Subtota1

2. QUOTATION COSTED ITEMS

\begin{tabular}{rr}
88.5 & 21.0 \\
61.0 & 14.5 \\
2.8 & 0.7 \\
2.0 & 0.5 \\
\hline 154.3 & 36.7
\end{tabular}

65.0

56.0

12.6

10.5

7.4

4.0

2.7

2.7

2.6

2.3

2.1

1.6

1.5

1.2

0.9

0.8

0.6

0.5

0.5

15.5

13.3

3.0

2.5

1.8

1.0

0.6

0.6

0.6

0.5

0.5

0.4

0.4

0.3

0.2

0.2

0.1

0.1

0.1

175.5

41.7

Subtotal 


\begin{tabular}{cc}
\multicolumn{2}{c}{ PWR } \\
\hline Cost & $\%$ of Total \\
$\$\left(10^{6}\right)$ & Plant Cost
\end{tabular}

3. HANDBOOK COSTED ITEMS
a. Wire and Cable
b. Electrical (except Wire and Cable Raceways)
c. Instrumentation and Control
d. Valves
e. Raceways
f. HVAC
g. Pumps
h. Insulation (Therma1)
i. Miscellaneous Reactor Items
j. Tanks
k. Nuclear Fuel Storage Tools
1. Pipe Whip Restraints
m. Communication Equipment
n. Suspense Items
o. Heat Exchangers
p. Water Treatment Equipment
q. Miscellaneous Structures
r. Air Compressors
s. Auxiliary Boilers
t. Fire Protection System
u. Miscellaneous
Subtota1

TOTAL

\begin{tabular}{rr}
13.5 & 3.2 \\
13.8 & 3.3 \\
11.3 & 2.7 \\
10.6 & 2.5 \\
8.1 & 1.9 \\
5.4 & 1.3 \\
4.3 & 1.0 \\
4.1 & 1.0 \\
4.0 & 1.0 \\
3.8 & 0.9 \\
2.3 & 0.5 \\
1.7 & 0.4 \\
1.4 & 0.3 \\
1.2 & 0.3 \\
1.1 & 0.3 \\
1.0 & 0.2 \\
0.9 & 0.2 \\
0.8 & 0.2 \\
0.6 & 0.1 \\
0.3 & 0.1 \\
0.9 & 0.2 \\
\hline & \\
91.1 & 21.6 \\
\hline \hline
\end{tabular}

$420.9 \quad 100.0$ 
Effective Date - 7/1/76

TABLE C2-2

Sheet 1 of 2

ENERGY ECONOMIC DATA BASE

RELATION OF INSTALLED COMPONENT COST TO TOTAL DIRECT PLANT COST

HS 8

\begin{tabular}{cl}
\hline Cost & $\%$ of Total \\
$\$\left(10^{6}\right)$ & P1ant Cost
\end{tabular}

1. COMPUTER COSTED ITEMS

a. Structural Commodities

48.1

17.5

b. Piping and Ductwork

31.7

11.5

c. Land Cost

d. Lighting and Service Power

2.0

0.7

1.4

0.5

Subtotal

83.2

30.2

2. QUOTATION COSTED ITEMS
a. Boiler
b. Turbine-Generator
c. $\mathrm{SO}_{2}$ Scrubbers
d. Coal Hand1ing Equipment
e. Precipitators
f. Cooling Towers
g. Condensers
h. Ash Handling
i. Boiler Feed Pumps and Turbines
j. Feedwater Heaters
k. Circulating Water Pumps
1. SO2 Booster Fan
m. Condensate Polishing System
n. Makeup Water Pretreatment System
o. Lime Hand1ing System
p. Water Treatment System
q. Diese1 Locomotives
r. Large Cranes
s. Diese1-Generator Units

Subtota1
49.4

29.5

9.5

8.5

8.3

6.2

5.9

4.9

3. 1

2.7

1.5

1.4

1.2

1.1

0.8

0.7

0.4

0.4

0.1

135.6
18. 0

10.7

3.5

3.1

3.0

2.3

2.1

1.8

1. 1

1.0

0.6

0.5

0.4

0.4

0.3

0.3

0.1

0.1

$*$

49.3

\footnotetext{
*Negligible
} 
Effective Date - 7/1/76

TABLE C2-2

Sheet 2 of 2

ENERGY ECONOMIC DATA BASE

RELATION OF INSTALLED COMPONENT COST TO TOTAL DIRECT PLANT COST

HS 8

\begin{tabular}{cl}
\hline Cost & $\%$ of Total \\
$\$\left(10^{6}\right)$ & P1ant Cost
\end{tabular}

3. HANDBOOK COSTED ITEMS

a. Electrical (except Wire and Cable Raceways)

b. Wire and Cable

14.9

6.7

7.3

5.4

c. Raceways

d. Instrumentation and Control

5.0

e. Insulation (Therma1)

f. Tanks

g. Valves

h. Pumps

i. Miscellaneous Equipment

j. HVAC

k. Miscellaneous Structures

4. 1

2.7

2.6

. 0

2.0

0.7

2.0

0.7

1. Air Compressors

1.7

0.6

1.3

0.5

1.0

0.4

m. Suspense Items

0.9

0.3

n. Auxiliary Boilers

o. Miscellaneous Drains

0.8

0.3

0.7

0.3

p. Heat Exchangers

q. Communication Equipment

0.6

0.2

r. Fire Protection System

0.6

0.2

0.2

s. Miscellaneous Fans

t. Miscellaneous

0.2

0.1

0.9

0.1

Subtota1

56.2

0.3

$=$

20.5

TOTAL

275.0

100.0 
APPENDIX D-1 
NSSS CAPITAL COSTS FOR A

MATURE LMFBR INDUSTRY

\author{
Prepared by \\ COMBUSTION ENGINEERING, INC. \\ $C-E$ Power Systems \\ 1000 Prospect Hill Road \\ Windsor, Connecticut 06095
}

Principal Investigator

Shakir U. Zaman

Prepared for

UNITED ENGINEERS \& CONSTRUCTORS, INC.

30 South 17 th Street

Philadelphia, Pennsylvania 19101

Project Manager

R. E. Allen 
Acknowledgements

This report was prepared under the valuable guidance of Dr. C. L. Storrs and Mr. R. C. Noyes. Major contributions to this study were made by Messrs. R. J. Bergeron, E. R. D'Ammadio, D. D. DeFur, C. F. G. Dupen, J. S. Greacen, M. A. Marroni, C. H. Meijer, P. O'Brien and K. E. Shotwell. 


\section{CONTENTS}

SECTION

TITLE

PAGE

1 SUMMARY $1-1$

1.1 Introduction $1-1$

1.2 Ground Rules $\quad 1-5$

1.3 Cost Summary $1-13$

$\begin{array}{ll}1.4 & \text { Comparison } \\ & 1-16\end{array}$

2 PLANT DESCRIPTION (NUCLEAR STEAM SUPPLY SYSTEM) $2-1$

2.1 Introduction 2-1

2.2 Plant Design Criteria 2-1

2.3 Plant Design Description 2-1

2.3.1 Reactor System 2-2

$\begin{array}{ll}\text { 2.3.2 Heat Transport Systems 2-21 } & \end{array}$

2.3.3 Auxiliary Heat Transfer System 2-42

2.3.4 Fuel Handling and Storage System 2-44

2.3.5 Inert Gas System 2-54

2.3.6 Auxiliary Liquid Metal System 2-60
2-6

2.3.7 Equipment Heating and Temperature Control System 2-64

2.3.8 Instrumentation and Control System 2-66

3 COST ESTIMATE $3-1$

3.1 Introduction 3-1

3.2 Cost Basis 3-1

3.3 Cost Estimate 3-7 


\section{CONTENTS (Cont'd)}

SECTION

TITLE

PAGE

4 COMPARISON AND DISCUSSION

4-1

5 DRAWINGS

$5-1$

6 EQUIPMENT LIST

$6-1$ 


\section{LIST OF TABLES}

TABLE

TITLE

PAGE

1.1 Summary of Principal NSSS Parameters

1.2 Comparison of Technical Plant Parameters - Target Plant Vs. PLBRS 1-6

1.3 Cost Estimate Summary

1.4 Exclusions For Cost Estimate

1.5 Comparison of Direct Capital Costs

2.1 Summary of Principal Plant Parameters

2.2 Summary of Preliminary Principal Reactor Parameters

4.1 Comparison of Reactor Vessels

4.2 Comparison of Closure Heads

4.3 Comparison of Reactor Vessel Internals

4.4 Comparison of Heat Transport System Pumps

4.5 Comparison of Steam Generators

4.6 Comparison of Secondary Sodium Expansion Tank and PWR Pressurizer

4.7 Comparison of Heat Transport System Piping and Valves

4.8 Comparison of Heat Transfer Area

4.9 Comparison of Storage Tank Volumes 


\section{LIST OF FIGURES}

FIGURE

TITLE

PAGE

2.1 Target Plant Layout 2-5

2.2 Reactor Vesse1 - Target Plant 2-7

2.3 Reactor Vessel Closure Head - Target Plant 2-11

2.4 Reactor Vessel Internals Assembly Elevation 2-15

$\begin{array}{lll}2.5 & \text { Reactor Vessel Internals Plan View 2-17 }\end{array}$

2.6 Primary and Intermediate Heat Transport Systems - Schematic 2-22

$\begin{array}{llr}2.7 & \text { Primary Pump 2-25 }\end{array}$

2.8 Intermediate Heat Exchanger - Target Plant 2-29

2.9 Expansion Tank - IHTS - Target Plant 2-35

2.10 Steam Generator (Combined Evap./S.H.) - Target Plant 2-39

2.11 Auxiliary Heat Transport System 2-43

\begin{tabular}{l}
2.12 Refueling Scheme 2-46 \\
\hline
\end{tabular}

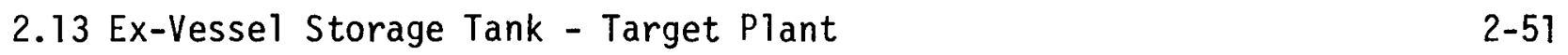

2.14 Radioactive Argon Processing System Schematic 2-57

2.15 Primary Sodium Purification System Schematic 2-63

4.1 Layout Comparison - Target Plant vs. C-E System $80 \quad 4-3$

4.2 Comparison of Reactor Vessels - Target Plant vs. C-E System 80 4-9

4.3 Comparison of Heat Transport System Pumps - Target Plant vs. C-E System $80 \quad 4-15$

4.4 Comparison of Steam Generators - Target Plant vs. C-E System $80 \quad 4-23$

5.1 Reactor Containment and PHTS - Plan View 5-3

5.2 Reactor Containment and PHTS - Elevation 5-5 


\section{LIST OF FIGURES (Cont'd)}

FIGURE

5.3 Steam Generator Building and IHTS Plan View

$5-7$

5.4 Steam Generator Building and IHTS Elevation

$5-9$

5.5 Reactor Service Building Layout

5.6 Reactor Service Building - Sectional Elevation

$5-13$

5.7 Auxiliary Building - Plan View

$5-15$

5.8 Auxiliary Building - Elevation 


\section{SECTION 1}

\section{SUMMARY}

\subsection{INTRODUCTION}

The conceptual design of a commercial LMFBR (Target Plant) and its NSSS capital cost have been developed in support of the United Engineers and Constructors Contract EN-78-C-02-4954 with the Department of Energy. The objective of this work is to provide the Department of Energy/Office of Program Planning and Analysis - Nuclear Energy Programs with periodic updates of technical, capital cost, fuel cycle cost, and operating and maintenance cost information. This effort supports Task $3 B$ of the UE\&C's Phase I Energy Economic Data Base (EEDB) Program.

Past estimates of LMFBR capital costs have generally predicted that these costs would be higher than those of a comparably sized LWR, primarily due to the more demanding technology associated with higher temperatures and the large number of engineered systems. The LMFBR, because of its low fuel cycle costs, can tolerate a capital cost premium relative to thermal reactors. The key issues, therefore, are: the allowable LMFBR cost premium, and the steps necessary to reduce the capital cost below the projected allowable cost premium for a safe and reliable plant.

Within the scope of the economic feasibility of a safe and reliable plant, the primary objectives of this study are as follows:

- Develop the capital cost estimate of the Target Plant NSSS.

- Identify areas where major cost savings could be implemented without compromising the safety and reliability of the plant.

- Establish a cost basis for further optimization of the plant. 
Considerable C-E effort has been devoted to the design and development of a loop-type commercial LMFBR (Target Plant). The four loop, 3800 MWT (1390 MWe) Target Plant has been designed with reasonable extrapolation of CRBRP components and permits direct cost and performance comparison with the C-E System 80 . The four-loop aspect of the plant also permits a scale down to three loops (1040 MWe) with identical component sizes and piping layout. A summary of the principal NSSS parameters for the Target Plant is given in Table 1.1.

The reactor vessel for the Target Plant is $27.0 \mathrm{ft}$. inside diameter and $49.0 \mathrm{ft}$. high, and is slightly bigger than the CRBRP vessel. Three rotating plugs in the reactor vessel head facilitate annual through-the-head refueling. Each of the four heat transport loops consists of a primary loop circulating radioactive sodium from the Reactor Vessel to an intermediate heat exchanger (IHX), and an intermediate sodium loop circulating non-radioactive sodium from IHX to the steam generators.

Each of the Primary Heat Transport System (PHTS) loops is rated at 950 Mwt and consists of a centrifugal variable-speed pump in the hot leg, an IHX, isolation valves and interconnecting piping. Each of the PHTS loops is located in an inerted cell within a $184.0 \mathrm{ft}$. inside diameter, Reactor Containment Building.

Each of the Intermediate Heat Transport System (IHTS) loops consists of a cold leg centrifugal pump, an expansion tank, two once-through steam generators rated at 475 Mwt each, isolation valves, and interconnecting piping. The water/steam flowing on the tube side of the steam generators is heated by the IHTS sodium flowing on the shell side of the steam generators.

There are two independent and redundant Auxiliary Heat Transport System (AHTS) loops rated at 57 Mwt each which provide for emergency decay heat removal from the reactor. Each of the AHTS loops transfers heat from the reactor vessel to a non-radioactive NaK loop via an Auxiliary Heat Exchanger. The heated NaK is circulated through air-blast heat exchangers for heat dissipation to the air. The primary legs of the AHTS, classified as Safety Class I, are 
TABLE 1.1

SUMMARY OF PRINCIPAL NSSS PARAMETERS

$\begin{array}{ll}\text { Plant Rating } & 3800 \mathrm{MWt} \\ \text { Electrical Rating (net) } & 1390 \mathrm{MWe} \\ \text { Steam Temperature } & 850^{\circ} \mathrm{F} \\ \text { Steam Pressure } & 2200 \mathrm{psig} \\ & \\ \text { Reactor Outlet Temperature } & 950^{\circ} \mathrm{F} \\ \text { Reactor Inlet Temperature } & 650^{\circ} \mathrm{F} \\ \text { Primary Sodium Flow/Loop } & 35.8 \times 10^{6} \mathrm{lbs} / \mathrm{hr} \\ & \\ \text { IHTS Sodium IHX Outlet Temperature } & 910^{\circ} \mathrm{F} \\ \text { IHTS Sodium IHX Inlet Temperature } & 590^{\circ} \mathrm{F} \\ \text { IHTS Sodium Flow/Loop } & 33.4 \times 10^{6} \mathrm{Tbs} / \mathrm{hr}\end{array}$


located within the Reactor Containment Building. The secondary legs, classified as Safety Class II, are located within Seismic Category I structures adjacent to the RCB.

The other systems included in the NSSS and described in Section 2 are:

Fuel Handling and Storage System

$\mathrm{Na} / \mathrm{H}_{2} \mathrm{O}$ Reaction Protection System

Inert Gas System

Liquid Metal Storage and Purification System

Equipment Heating and Temperature Control System

Instrumentation and Control System

The unique features in the plant which are believed to be cost-effective are as follows:

- In-vessel check valves to minimize loss of coolant and to ensure core cooling on loss of one loop. Need for guard vessels for components is diminished.

- Siphon - breaker lines to minimize loss of coolant. In conjunction with the in-vessel check valves, these lines ensure that the sodium level in the vessel remains above the minimum safe level for decay heat removal. No guard vessels for pumps and IHX's are required.

- An advanced design, redundant secondary Shutdown System ensures automatic reactor shutdown upon loss of flow. It's independence from occurences outside the reactor boundary eliminates common mode failure possibilities. As a result the reactor system, the heat transport systems and the Reactor Containment Building are not dependent upon CDA considerations.

- Once-through steam generators (Benson Cycle) eliminate miscellaneous components needed for other cycles. The steam generator design is simplified and its duty cycle is moderated. 
- Provision of two independent and redundant AHTS, directly off the reactor vessel, eliminates the need for emergency decay heat removal through the IHTS. Hence, the IHTS and steam generator system (SGS) train outside the RCB may be designed to commercial standards without compromizing the plant and public safety. The IHTS and SGS are therefore classified as non-nuclear safety systems; and the steam generator buildings are non-seismic Category I structures and are designed to the uniform building code.

- The steam generator buildings are positioned symmetricaliy around the Reactor Containment Building in a satellite arrangement. This arrangement results in identical (or mirror image) layouts of the piping and components, with substantial reduction in the piping runs and the number of expansion loops. Piping analys is conducted for one loop is applicable to all loops and fabrication, erection and support systems are identical for a11 loops.

- The Cavity Filler System, consisting of replaceable filler blocks, is designed for ease of installation and inservice inspection of the reactor vesse1. The material cost savings for such a system as compared to a guard vessel may be marginal, but access for the installation of the reactor vessel and the connected piping is improved substantially. This leads to improvements in field erection costs and schedule.

A summary of the Target Plant parameters in comparison with PLBR is given in Table 1.2 .

\subsection{GROUND RULES}

The major ground rules used in this study are as follows:

- The reactor plant design is based on the Target Plant described in Section 2.0, key plant parameters are shown in Table 1.1. 
COMPARISON OF TECHNICAL PLANT PARAMETERS -

TARGET PLANT VS. PLBR'S

\section{Parameter}

A. Genera1

1. Thermal power, MWt

2. Electric power, MWe (gross)

3. Electric power, MWe (net)/Eff.\%

4. Primary heat transport system configuration

5. Steam conditions, turbine inlet, full power

a. Pressure, psig

b. Temperature, ${ }^{\circ} \mathrm{F}$

6. Feedwater temperature, ${ }^{\circ} \mathrm{F}$

7. Feedwater Flow, $10^{6} \mathrm{lb} / \mathrm{hr}$

8. Turbine Steam Flow, $10^{6} \mathrm{lb} / \mathrm{hr}$

B. Reactor

1. Core lattice configuration

a. Geometry.

b. Total number of lattice positions

Hexagonal
799

(includes

270 for

shielding)

Phase II

2550

990

$925 / 36.3$

Piped

1015

546

420

13.1708

11.9183

9.0345

8.0604

2285

855

380

9.0345

Hexagonal

769

(includes

258 for

shielding)
AI
(Loop)
Phase II

AI

(Pool)

Phase I

$C-E$ Target

Plant

N/A indicates Parameter Not Applicable.

--- indicates Missing Data 
TABLE 1.2 (Continued)

\begin{tabular}{|c|c|c|c|c|c|}
\hline Parameter & $\begin{array}{c}\text { GE } \\
\text { Phase II }\end{array}$ & Phase II & $\begin{array}{c}\text { AI } \\
\text { (Loop) } \\
\text { Phase II }\end{array}$ & $\begin{array}{l}\text { AI } \\
\text { (Pool) } \\
\text { Phase I }\end{array}$ & $\begin{array}{l}\text { C-E } \\
\text { Target } \\
\text { Plant }\end{array}$ \\
\hline
\end{tabular}

C. Reactor Vessel (piped) or Primary Tank (pool)

1. Dimensions
a. Inside diameter, in.
b. Height, in.
c. Wal1 thickness, in.

2. Material
528

714

$---$

304 SS

\section{5}

647.5

1.75 to 5

304 SS

$3 / 3$

$115 / 28.8$

$122 / 30.5$

a. Primary (total/per loop)

b. Intermediate (total/per loop)

3. Coolant temperature, ${ }^{\circ} \mathrm{F}$
a. Primary (hot leg/cold leg)
b. Intermediate (hot leg/cold leg)
$875 / 595$
$815 / 550$

4. Pumps
a. No. of pumps per loop
(primary/intermediate)
b. Pump capacity, $10000 \mathrm{gpm}$
(primary/intermediate)
c. Pump location

\begin{tabular}{|c|c|c|c|c|}
\hline $1 / 1$ & $1 / 1$ & $1 / 1$ & $1 / 1$ & $1 / 1$ \\
\hline $68.4 / 71.6$ & $82.0 / 82.1$ & $83.2 / 74.0$ & $93.3 / 80.0$ & $86.2 / 76.7$ \\
\hline $\begin{array}{l}\text { Hot Leg/ } \\
\text { Hot Leg }\end{array}$ & $\begin{array}{l}\text { Hot Leg/ } \\
\text { Cold Leg }\end{array}$ & $\begin{array}{l}\text { Hot Leg/ } \\
\text { Cold Leg }\end{array}$ & $\begin{array}{l}\text { Cold Leg/ } \\
\text { Cold Leg }\end{array}$ & $\begin{array}{l}\text { Hot Leg/ } \\
\text { Cold Leg }\end{array}$ \\
\hline
\end{tabular}

Hot Leg
Cold Leg
Cold Leg
Hot Leg/
Cold Leg

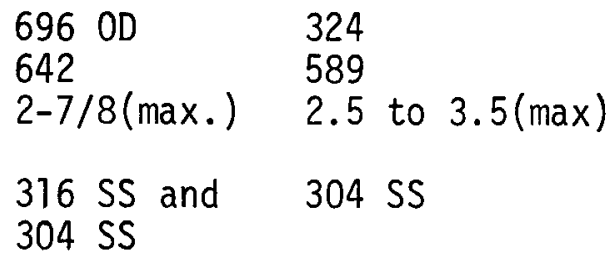

$3 / 3$

$4 / 4$

$95.3 / 31.8 \quad 104 / 34.7 \quad 110.7 / 36.9 \quad 143.2 / 35.8$

$\begin{array}{llll}94.18 / 31.4 & 97.4 / 32.5 & 108.9 / 36.3 & 133.6 / 33.4\end{array}$

\section{$947.5 / 647.5 \quad 930 / 650$}

$900 / 600$

$980 / 715$

$950 / 650$

$940 / 670$

$910 / 590$ 
TABLE 1.2 (Continued)

Parameter

GE
Phase II $\frac{W}{\mathrm{~W}}$ II

straight tube counterflow she11 side
$1 / 2.05 \times 10^{5}$

c. No. of modules per primary loop/ total sq. ft.

6. Steam generators

a. Configuration

$\bar{d}$

b. Intermediate coolant location

c. Tube material

(1) Evaporator

(2) Superheater

(3) Reheater

d. No. of modules per intermediate loop

(1) Evaporator/total sq. ft.

(2) Drum

(3) Superheater/total sq. ft.

(4) Reheater/total sq. ft.

7. Coolant system piping and valving

a. Means of accommodating deflections

\begin{tabular}{|c|c|}
\hline $\begin{array}{l}\text { straight } \\
\text { double-wall } \\
\text { tubes with } \\
\text { recirculation } \\
\text { (6 to } 1 \text { ) } \\
\text { shell side }\end{array}$ & $\begin{array}{l}\text { straigh } \\
\text { double- } \\
\text { tubes w } \\
\text { continu } \\
\text { blowdow } \\
\text { ( } 4-3 / 4 \% \\
\text { shell s }\end{array}$ \\
\hline $2-1 / 4 \mathrm{Cr} 1 \mathrm{Mo}$ & -- \\
\hline $\begin{array}{l}N / A \\
N / A\end{array}$ & \\
\hline $\begin{array}{l}1 / 2.49 \times 10^{5} \\
1 \\
N / A \\
N / A\end{array}$ & $\begin{array}{l}1 / 2.04 \\
1 \\
1 /--- \\
N / A\end{array}$ \\
\hline
\end{tabular}

Expansion loops straight tube counterflow she 11 side $_{5}$
$1 / \sim 7.80 \times 10^{5}$

straight tube counterflow shell side 5 $1 / 2.17 \times 10^{5}$

(Loop)

Phase II

$1 / 2.17 \times 10^{3}$ straight tube straight tube counterflow counterflow shell side 5 shell side $2 / 2.129 \times 10^{5} \quad 1 / 2.264 \times 10^{5}$ 
TABLE 1.2 (Continued)

Parameter

GE

Phase $\stackrel{\text { W }}{\mathrm{e}}$ II

AI
(Loop)
Phase II

$\begin{array}{cl}\text { AI } & \text { C-E } \\ \text { (Pool) } & \text { Target } \\ \text { Phase I } & \text { Plant }\end{array}$

D. 7. b. Pipe outside diameter, inc.

(1) Primary (hot leg/cold leg) 36/36

(2) Intermediate (hot leg/cold leg) $36 / 36$

$36 / 36$

$36 / 36$

$36 / 2-28$

$36 / 36$

$26 /---$

$44 / 36 \& 36$

c. Materials

(1) Primary (hot legs/cold leg)

304 SS/304 SS

316 SS/304 SS 316 SS/304 SS

$36 / 36$

$36 / 36$

(2) Intermediate (hot $1 \mathrm{eg} / \mathrm{cold}$ leg)

304 SS/304 SS

316 SS/2-1/4 304 SS/304 SS

$316 \mathrm{SS} / 304 \mathrm{SS}$

$\mathrm{Cr} 1 \mathrm{mo}$

(Ex. Cont.)

304 SS

(In. Cont.)

d. Primary coolant valves (hot leg stop/ No/No/Yes No/No/Yes

No/No/Yes

No/Yes/No

Yes/Yes/Yes

e. Intermediate coolant valves (steam No generator module isolation)

No

Yes

Yes

E. Turbine-Generator

1. Type

2. Speed, $\mathrm{r} / \mathrm{min}$

F. Auxiliary Systems

1. Coolant purification method

2. Inert gas systems

a. Gas \& Pressure

(1) Primary

(2) Intermediate

(3) Equipment cells

b. Inert cell atmosphere coolant

$\begin{array}{llll}\text { Tandem } & \text { Tandem } & \text { Tandem } & \text { Tandem } \\ \text { Compound, } & \text { Compound, } & \text { Compound, } & \text { Compound } \\ 4 \text { Flow, } & 6 \text { Flow, } & 4 \text { Flow, } & 6 \text { Flow, } \\ \text { Reheat } & \text { Reheat } & & \text { Reheat } \\ 1800 & 3600 & 1800 & 3600\end{array}$

Cold Trap

Cold Trap

Cold Trap

Cold Trap

Cold Trap

Ar - 10"WG

Ar - 0 psig

$\mathrm{He}-10 " W G$

He - 10" WG

Ar

Ar - 130 psia

$\mathrm{Ar}$ - 140 psig

$\mathrm{N}_{2}^{2-\cdots}$

$\mathrm{N}_{2}^{-}-\cdots$

$\mathrm{Ar}-\cdots$
$\mathrm{N}_{2}-\cdots$
$\mathrm{N}_{2}^{-}---$

He - - -

$\mathrm{N}^{2}-\cdots$

Ar

$\mathrm{N}_{2}$ 
TABLE 1.2 (Continued)

Parameter

G. Shielding, Containment, Safety Features

1. Shielding material

a. In-vessel

b. Ex-vessel

2. Containment

a. Design basis

(1) Tornado wind loading, mph

(2) Seismic acceleration (horizontal/vertical) SSE

(3) HCDA energy release, MW-sec

b. Configuration

c. Dimensions, ft.

d. Material

e. Gross volume, $10^{6} \mathrm{cu} \mathrm{ft}$

f. Design pressure, psig

g. Allowable leak rate (vol. \%/day)

3. Principal engineered safety features

\begin{tabular}{|c|c|c|c|c|}
\hline $\begin{array}{l}304 \text { SS } \\
\text { Concrete }\end{array}$ & $\begin{array}{l}316 \text { SS } \\
\text { Concrete }\end{array}$ & $\begin{array}{l}\text { Steel } \\
\text { Concrete }\end{array}$ & $\begin{array}{l}\text { Steel } \\
\text { Concrete }\end{array}$ & $\begin{array}{l}\text { Steel/graphite } \\
\text { Concrete }\end{array}$ \\
\hline $\begin{array}{l}360 \\
0.30 /---\end{array}$ & $\begin{array}{l}360 \\
---1---\end{array}$ & $\begin{array}{l}360 \\
0.3 / \text { R.G. } 1.60 \\
0.4 \text { for NSSS }\end{array}$ & $\begin{array}{l}360 \\
0.3 / R . G .1 .60 \\
0.4 \text { for NSSS }\end{array}$ & 360 \\
\hline $\begin{array}{l}\text { Rectangular } \\
222 / 210 / 184 \\
\text { Reinforced } \\
\text { Concrete }\end{array}$ & $\begin{array}{l}\text { Domed } \\
\text { Cyl inder } \\
228 / 166 \\
\text { Reinforced } \\
\text { Concrete }\end{array}$ & $\begin{array}{l}\text { Domed } \\
\text { Cylinder } \\
220 / 185 \text { ID } \\
\text { Reinforced } \\
\text { Concrete }\end{array}$ & $\begin{array}{l}\text { Domed } \\
\text { Cylinder } \\
183 / 118 \text { ID } \\
\text { Reinforced } \\
\text { Concrete }\end{array}$ & $\begin{array}{l}\text { Domed } \\
\text { Cylinder } \\
184 \text { ID } \\
\text { Reinforced } \\
\text { Concrete }\end{array}$ \\
\hline $\begin{array}{l}8.58 \\
3.0 \\
0.17 \text { to con- } \\
\text { finement } \\
\text { - Removal of } \\
\text { decay heat by } \\
4 \text { independent } \\
\text { cooling loops }\end{array}$ & $\begin{array}{l}4.86 \\
10 \\
0.2 \% \text { (Pri- } \\
\text { mary cont.) } \\
\text { - Removal of } \\
\text { decay heat by } \\
3 \text { independent } \\
\text { redundant } \\
\text { cooling loops } \\
\text { or auxiliary } \\
\text { feedwater }\end{array}$ & $\begin{array}{l}5.52 \\
3 \\
0.001 \% \\
\text { (Cont./Conf.) } \\
\text { - Removal of } \\
\text { decay heat } \\
\text { by } 2 \text { diverse } \\
\text { cooling } \\
\text { systems }\end{array}$ & $\begin{array}{l}1.855 \\
3 \\
--- \\
\text { - Removal of } \\
\text { decay heat } \\
\text { by two } \\
\text { diverse } \\
\text { cooling } \\
\text { systems }\end{array}$ & $\begin{array}{l}\text { - Removal of } \\
\text { decay heat } \\
\text { by } 2 \text { redun- } \\
\text { dant, inde- } \\
\text { pendent aux. } \\
\text { heat transfer } \\
\text { systems }\end{array}$ \\
\hline
\end{tabular}

(Loop)

Phase II

\section{AI \\ (Pool)}

C-E

Target

Plant 
TABLE 1.2 (Continued)

Parameter

G. 3. Principal engineered safety features (Continued)

$\quad$ GE
Phase II
-Containment
isolation on
increased
radiation
-Elevated
piping guard
vessel concept
to limit effect
of pipe rupture
-2 redundant
100\% capacity
gas-engine
generators
for decay
heat removal

H. Protection and Control

1. Principal reactor protection criterion

2. Reactor protection method

3. Reactor power control basis

\begin{tabular}{|c|c|c|c|}
\hline Phase $\frac{W}{\mathrm{~W}}$ II & $\begin{array}{l}\text { AI } \\
\text { (Loop) } \\
\text { Phase II }\end{array}$ & $\begin{array}{c}\text { AI } \\
\text { (Pool) } \\
\text { Phase I }\end{array}$ & $\begin{array}{l}\text { C-E } \\
\text { Target } \\
\text { Plant }\end{array}$ \\
\hline $\begin{array}{l}\text {-Containment } \\
\text { isolation } \\
\text {-3 100\% capa- } \\
\text { city diese1 } \\
\text { generators }\end{array}$ & $\begin{array}{l}\text { - Containment } \\
\text { isolation on } \\
\text { increased } \\
\text { radiation or } \\
\text { reactor } \\
\text {-Elevated } \\
\text { piping guard } \\
\text { vessel con- } \\
\text { cept to limit } \\
\text { effect of } \\
\text { pipe rupture } \\
\text { - } 3 \text { diesel } \\
\text { generators }\end{array}$ & $\begin{array}{l}\text {-Containment } \\
\text { isolation on } \\
\text { increased } \\
\text { radiation } \\
\text { trip } \\
\text {-Primary } \\
\text { sodium } \\
\text { restricted } \\
\text { to reactor } \\
\text { vessel } \\
\text {-2 redundant } \\
\text { full capacity } \\
\text { diesel } \\
\text { generators }\end{array}$ & $\begin{array}{l}\text {-Containment } \\
\text { isolation; } \\
\text { check valves } \\
\text { in RV, and } \\
\quad \text { Siphon } \\
\text { breaker lines } \\
\text { to limit } \\
\text { effects of } \\
\text { pipe rupture } \\
-2 \text { redundant } \\
100 \% \text { capacity } \\
\text { diesel } \\
\text { generators }\end{array}$ \\
\hline $\begin{array}{l}2 \text { diverse } \\
\text { independent } \\
\text { reactor shut- } \\
\text { down systems } \\
\end{array}$ & $\begin{array}{l}3 \text { diverse } \\
\text { independent } \\
\text { reactor shut- } \\
\text { down systems } \\
---\end{array}$ & $\begin{array}{l}3 \text { diverse } \\
\text { independent } \\
\text { reactor shut- } \\
\text { down systems } \\
\text {--- }\end{array}$ & $\begin{array}{l}2 \text { diverse } \\
\text { independent } \\
\text { shutdown } \\
\text { systems } \\
\text {--- }\end{array}$ \\
\hline $\begin{array}{l}\text { Nominally } \\
\text { constant } \\
\text { steam }\end{array}$ & $\begin{array}{l}\text { Nominally } \\
\text { constant } \\
\text { steam }\end{array}$ & $\begin{array}{l}\text { Nominally } \\
\text { constant } \\
\text { steam }\end{array}$ & $\begin{array}{l}\text { Constant } \\
\text { steam } \\
\text { pressure and }\end{array}$ \\
\hline $\begin{array}{l}\text { pressure, } \\
\text { variable } \\
\text { steam tem- } \\
\text { perature and } \\
\text { reactor } \\
\text { outlet }\end{array}$ & $\begin{array}{l}\text { pressure, } \\
\text { variable } \\
\text { steam flow, } \\
\text { constant } \\
\text { steam } \\
\text { temperatures }\end{array}$ & $\begin{array}{l}\text { pressure, } \\
\text { variable } \\
\text { steam flow, } \\
\text { constant steam } \\
\text { temperatures }\end{array}$ & $\begin{array}{l}\text { temperature, } \\
\text { variable } \\
\text { steam flow }\end{array}$ \\
\hline
\end{tabular}

2 diverse independent reactor shutdown systems

Nomina 11y constant

steam pressure, variable steam flow, constant steam temperature
2 diverse independent steam temperature, variable steam flow 
TABLE 1.2 (Continued)

Parameter

H. 4. Reactor flow control basis

I. Refueling

1. Operations within reactor vessel or primary tank

2. Removed from reactor vessel or primary tank

3. Spent fuel decay storage positions

\section{GE}

Phase II

Nominally
constant
power to
flow ratio

Underhead

transfer of

fuel to

transfer bucket

via fixed

transfer tube

to fuel storage

tank in

containment

727 in fuel storage tank $(1.37 \times$ core $)$

Phase II $\begin{aligned} & \text { AI } \\ & \text { (Loop) } \\ & \text { Phase II }\end{aligned}$

Nominally Nominally

constant

coolant $\Delta T$.

constant

outlet

temperature

Underhead transfer of fuel to

transfer

bucket

via fixed

transfer

tube to

excontain-

ment fuel

storage tank

$\stackrel{704}{(1.38 \times \text { core })(1.39 \times \text { core })}$

Underhead

transfer of

fuel to

transfer

bucket

via fixed

transfer tube $t$

in- tube to

ment fuel excontain-

storage tank ment fuel

AI

Phase I

$C-E$

\section{Target}

Plant

Nominally Nominally

constant

outlet

temperature

constant

outlet

temperature

storage tank 707

includes includes

reflectors reflectors
Underhead

transfer of

fuel to

transfer pot

via fixed

transfer

tube to in-

containment

fuel storage

tank

298 core

assemblies 
- $\quad$ Cost data is based on prices as of January 1978.

- The cost estimate is for a single unit fifth-of-a-kind plant.

- The cost estimate is developed in accordance with a modified version of the AEC Code of Accounts (USAEC Report NUS-531).

- Safety classification, seismic categories, and design codes for the components are given in the Equipment List (Section 6).

- Escalation and interest during construction are not included in the cost estimate.

- The plant has on-site reactor core storage capacity for $1 / 3$ core.

- The plant is designed for 40-years life.

- The plant is base loaded with availability of better than $90 \%$ (including refueling downtime).

\section{$1.3 \quad$ COST SUMMARY}

The estimated total cost of the Target Plant NSSS is $\$ 267,574,000$ (Table 1.3) subject to the exclusions noted in Table 1.4. The costs associated with engineering (design changes, modifications and development), erection and startup services are also shown in Table 1.3 under the item "engineering" which may be reallocated to indirect costs.

The estimated costs are based on F.0.B. vendor shop sell prices of the components listed in the equipment list (section 6). These costs include the component engineering, materials, fabrication and the company margin in January 1978 dollars. The costs do not include escalation, interest during construction, erection and field equipment, and labor. 
TABLE 1.3

\section{COST ESTIMATE SUMMARY}

COSTS
(Thousands of Dollars)

\begin{tabular}{|c|c|c|}
\hline $220 A .211$ & Reactor Vessels & 31,881 \\
\hline $220 A .212$ & Reactor Vessel Internals & 13,619 \\
\hline $220 A .213$ & Control Rod System & 2,730 \\
\hline $220 A .221$ & Primary Heat Transport System & 59,442 \\
\hline $220 A .222$ & Intermediate Heat Transport System & 23,323 \\
\hline $220 A .23$ & Steam Generation System & 48,499 \\
\hline $220 A .23$ & Safeguards System & 9,431 \\
\hline $220 A .25$ & Fuel Handling and Storage System & 29,902 \\
\hline $220 A .26$ & Other Equipment & 29,378 \\
\hline \multirow[t]{4}{*}{$220 A .27$} & Instrumentation + Controls & 19,369 \\
\hline & NSSS Costs (Partial - & \\
\hline & Exclusions Noted in Table 1.4) & 267,574 \\
\hline & Engineering & 15,330 \\
\hline
\end{tabular}


TABLE 1.4

\section{EXCLUSIONS FOR COST ESTIMATES}

220A. 21122

220A.21251

220A. 21252

220A. 21253

220A. 21254

$220 A .2216$

$220 A .2226$

$220 A .2236$

220A. 267

220A. 268
Heating and Cooling Equipment

(Reactor Vessel Head)

Core Assemblies

Blanket Assemblies

Reflector and Shield

Fuel Transfer Assemblies

Insulation

(Primary Heat Transport System)

Insulation

(Intermediate Heat Transport System)

Insulation

(Steam Generation System)

Auxiliaries Cooling Equipment

Maintenance Equipment 
The cost estimates for the major components of the Target Plant (Reactor vesse1, IHX, steam generators) were developed by C-E using a cost basis similar to that used for C-E System 80 components. The cost estimates for the piping systems were derived from 1974 CRBRP cost estimates, adjusted to 1978 dollars.

The cost estimates for the reactor vessel internals and the reactor enclosure system have been developed using a cost basis similar to the C-E System 80 components.

The cost estimates for the primary and secondary pumps are based on prices developed by the Byron Jackson Co. for large sodium pumps.

The cost estimate for the fuel handling and storage system is generally based on similar components for C-E System 80 except for the EVST and the fuel handling machines which are based on CRBRP with some adjustments for a fifth-of-a-kind plant.

The cost estimates for the conventional components such as tanks, piping, valves, etc. of the auxiliary systems are based on similar components for C-E System 80. The cost estimates for the sodium components were developed through quotations from vendors.

In summary, the cost basis of C-E System 80 has been generally utilized for the Target Plant components except for the sodium components, for which approximate prices were obtained from various vendors.

\subsection{COMPARISON}

A comparison of the estimated costs of the major components of the Target Plant with those of the CRBRP and the PLBR is shown in Table 1.5. When the cost numbers are adjusted for the power differences, there seems to be good agreement between the PLBR and the Target Plant prices for the majority of the components, such as the reactor vessel, the vessel internals, the 
TABLE 1.5

COMPARISON OF DIRECT CAPITAL COSTS

(in Millions of Dollars)

\begin{tabular}{llcc} 
CRBRP & AI /B\&R & GE/BECHTEL & CE/UE\&C \\
& PLBR & PLBR & \\
$975 \mathrm{MWt}$ & $2600 \mathrm{MWt}$ & $2890 \mathrm{MWt}$ & $3800 \mathrm{MWt}$ \\
1978 & 1977 & 1977 & 1978 \\
\hline
\end{tabular}

NSSS COSTS

\section{REACTOR SYSTEM}

Reactor Vessel

Reactor Internals

Total

\begin{tabular}{rr}
34.88 & 18.62 \\
15.24 & 11.94 \\
\hline 50.12 & $\frac{}{30.56}$ \\
& \\
76.23 & 7.49 \\
6.37 & 6.23 \\
15.68 & 13.11 \\
$\frac{39.00}{137.28}$ & 4.74 \\
& $\frac{17.11}{46.68}$
\end{tabular}

29.30

$\frac{(\text { Incl.) }}{29.30}$

25.92

13.62

HEAT TRANSPORT SYSTEM

Primary Pumps

Intermediate Pumps

7.49
6.23

3.11

imary Piping

4.74

IHX's

Total HTS System

$\frac{17.11}{46.68}$

29.70

14.00

12.29

14.57

$\frac{26.40}{96.96}$

$\frac{26.40}{96.96}$

18.16

14.80

13.05

2.82

21.45

$\overline{70.28}$

\section{STEAM GENERATOR SYSTEM}

\section{Evaporators}

Superheaters

96.35

44.20

40.20

(Inc1.)

20.50

$\frac{1.50}{97.85}$

$\overline{---\cdot-}$

$\frac{6.60}{67.30}$

$\frac{6.60}{67.30}$

41.99

(Incl.)

$\frac{0}{41.99}$

Total SG System

NSSS

TOTAL COST (OF THE ABOVE)

285.25

123.44

193.56

151.81 
primary pumps, the primary piping, and the IHX. Higher prices for the CRBRP components reflect on the first-of-a-kind nature of the plant, and may include substantial costs associated with research and development and shop retooling.

The secondary piping and associated components of the Target Plant are designed and fabricated to commercial standards and therefore cost less than those for PLBR. The steam generators, also designed to commercial standards, are straight tube once-through units (Benson cycle). Their lower costs are due to both simplicity of design and fabrication, and the smaller number of units as compared to the PLBR designs.

As compared to a PWR, the major cost increases are related to the physical requirements of the LMFBR design; including the requirement for intermediate loops in the coolant system, the addition of a sodium-water protection system for the steam generators, unique piping requirements for the high temperature sodium systems, and a large number of engineered systems.

The conceptual design of the Target Plant was developed using extrapolations of the available information from CRBRP and other LMFBR studies. For large components such as the reactor vessel, vessel internals, closure head, IHX, and the steam generators, the design evolved by extrapolation with limited effort devoted to their optimization. Due to the significant portion of the capital cost associated with these components, further optimization will result in some reduction in the capital cost of the Target Plant.

The cost estimates for the refueling system and the auxiliary systems have been conservatively developed based on extrapolation of the design of CRBRP and limited cost information available for sodium components. Further effort in simplifying this design and improvements in the cost estimates should lead to some reduction in NSSS costs. Similarly a cost reduction seems possible in the I\&C costs with better definition of design and costs. 
Several design changes have been proposed to reduce the capital cost of the LMFBR. Of those which could be implemented in the near term, the most promising are the following:

(1) Use of super-chrome ferritic steel for sodium components and piping instead of austenitic steel;

(2) Bellows joints instead of expansion loops to accommodate thermal expansion in the sodium piping;

(3) Three heat transfer loops instead of four.

Each of these concepts has an impact on the design, operation and licensability of the plant. By paying careful attention to these things it may be possible to reduce the capital cost significantly without compromising the safety and reliability of the plant. 


\author{
SECTION 2 \\ PLANT DESCRIPTION \\ (NUCLEAR STEAM SUPPLY SYSTEM)
}

\title{
$2.1 \quad$ INTRODUCTION
}

This section describes the C-E Target Plant design. The material presented in this section is organized to correspond to Account 22 of the uniform system of accounts (USAEC Report NUS-531) used for the detailed cost estimate. This format correlates the plant design description with the detailed cost estimate (Section 3) and the detailed equipment list (Section 6).

A summary description is provided in Section 2 for each major account. This is followed by detailed descriptions of major components for each system.

\subsection{PLANT DESIGN CRITERIA}

The major criteria for the Target Plant Cost Study have been addressed in Section 1.2. The plant is designed for a 40-year life. The thermal power of the plant is 3800 Mwt in accordance with the NRC upper limit and equal to the power of the C-E System 80 . The plant is a loop design which permits extrapolation of the CRBRP arrangement for sodium systems. The reactor cover gas is argon. Safety classifications, seismic categories and design codes for the major components, as interpreted from NRC regulatory guides, are given in the Equipment List (Section 6).

\section{$2.3 \quad$ PLANT DESIGN DESCRIPTION}

The Target Plant reference design is a 3800 Mwt loop-type, sodium-cooled, fast-breeder reactor plant. The reactor vessel is large enough to accommodate heterogeneous or homogeneous core designs, oxide or carbide fuel, and thorium or uranium fertile assemblies. Connected to the reactor vessel are 
four primary heat transport loops, two auxiliary heat transport loops, the overflow and makeup sodium loop, and the argon cover gas loop. The principle parameters of the Target Plant are summarized in Table 2.1.

Each of the primary heat transport loops, rated at 950 MWt, transfers heat from the reactor to the Intermediate Heat Exchanger (IHX) where the heat is transferred to the intermediate heat transport system (IHTS). The IHTS consists of an IHTS pump, expansion tank, and associated piping and valves, and transfers the heat to the water and steam side (tube side) of the steam generators.

The reactor system, the Primary Heat Transport System (PHTS), a portion of the fuel handling system, and most of the radioactive auxiliary systems are located in the Reactor Containment Building. The Intermediate Heat Transport System (IHTS) and the Steam Generator System (SGS) are located in the Steam Generator building. The remaining fuel handling facilities and equipment and the Auxiliary Systems are located in the Reactor Service Building and the Auxiliary Buildings. The plant arrangement is shown in Figure 2.1. The system layout drawings are given in Section 5 .

\subsubsection{Reactor System}

\subsubsection{Reactor Vessel and Reactor Vessel Closure Head}

The reactor vessel is placed centrally within the LMFBR NSSS. This vessel, with the closure head installed, provides the primary coolant boundary for the core and the core coolant fluid (molten sodium). The molten sodium, while serving as a coolant for the core, picks up heat and thus becomes the working heat transfer medium for the LMFBR System.

A major portion of the sodium flow enters the reactor vessel from each of the four primary loops through the high pressure inlet nozzles while the remaining portion enters through the low pressure inlet nozzles. The inflowing fluid is combined in the respective high and low pressure inlet 


\section{SUMMARY OF PRINCIPAL PLANT PARAMETERS}

Plant Thermal Rating

Electrical Rating (net)

Type

Steam Temperature

Steam Pressure

Feedwater Temperature

Primary Sodium Temperatures, Hot/Cold

Secondary Sodium Temperatures, Hot/Cold

Primary Sodium Flow Rate/Loop

Secondary Sodium Flow Rate/Loop

Primary Pump

Secondary Pump

Steam Generators
$3800 \mathrm{MWt}$

1390 MWe

Loop, 4 Loops

$850^{\circ} \mathrm{F}$

2200 Psig

$470^{\circ} \mathrm{F}$

$950 / 650^{\circ} \mathrm{F}$

$910 / 590^{\circ} \mathrm{F}$

$35.8 \times 10^{6} 1 \mathrm{bm} / \mathrm{hr}$

$33.4 \times 10^{6} \mathrm{1bm} / \mathrm{hr}$

Single-Stage Centrifugal, $86,200 \mathrm{gpm}$ at $375 \mathrm{ft}$.

Single-Stage Centrifugal, $76,700 \mathrm{gpm}$ at $300 \mathrm{ft}$.

Once-through, straight-tube Two per loop

475 MWt each 
plena and is passed upward through the core region of the reactor vesse 1 where it is heated prior to exiting into the large outlet plenum above the core. (A description of the reactor internals is given in 2.3.1.2). The hot leg primary pumps supply the IHX's with heated sodium drawn from the outlet plenum through nozzles provided in the upper shell region of the vessel.

The reactor vessel closure head provides the required thermal and biological shielding, serves as a cover gas seal, and provides access for manipulating core elements, control rod, and other hardware which must be periodically removed and replaced, inserted and withdrawn, etc., as required to operate the reactor system.

As shown in Figure 2.2, the reactor vessel is a vertically oriented, top supported, cylindrical component with a lower eliptical head. Except for the uppermost she11 course and the shell/flange transition, the vessel has a constant thickness of 2.50 inches. The uppermost shell course and she11/flange transition are 3.00 inches thick. The vessel wall is penetrated by 28 nozzles, the sizes and functions of which are as tabulated below:

\begin{tabular}{|c|c|c|}
\hline Quantity & Outside Diameter & Function \\
\hline 4 & 36.00 inch & High Pressure Sodium Inlet \\
\hline 4 & 14.00 inch & Low Pressure Sodium Inlet \\
\hline 2 & 12.75 inch & Auxiliary Sodium Inlet \\
\hline 4 & 44.00 inch & Sodium Outlet \\
\hline 2 & 12.75 inch & Auxiliary Sodium Outlet \\
\hline 1 & 8.63 inch & Sodium Make-up \\
\hline 1 & 10.75 inch & Sodium Overflow \\
\hline 4 & 8.63 inch & Siphon Breaker \\
\hline 4 & $10.75 \mathrm{inch}$ & Pump Overflow \\
\hline 1 & 4.50 inch & Cover Gas Inlet \\
\hline 1 & 4.50 inch & Cover Gas Outlet \\
\hline
\end{tabular}




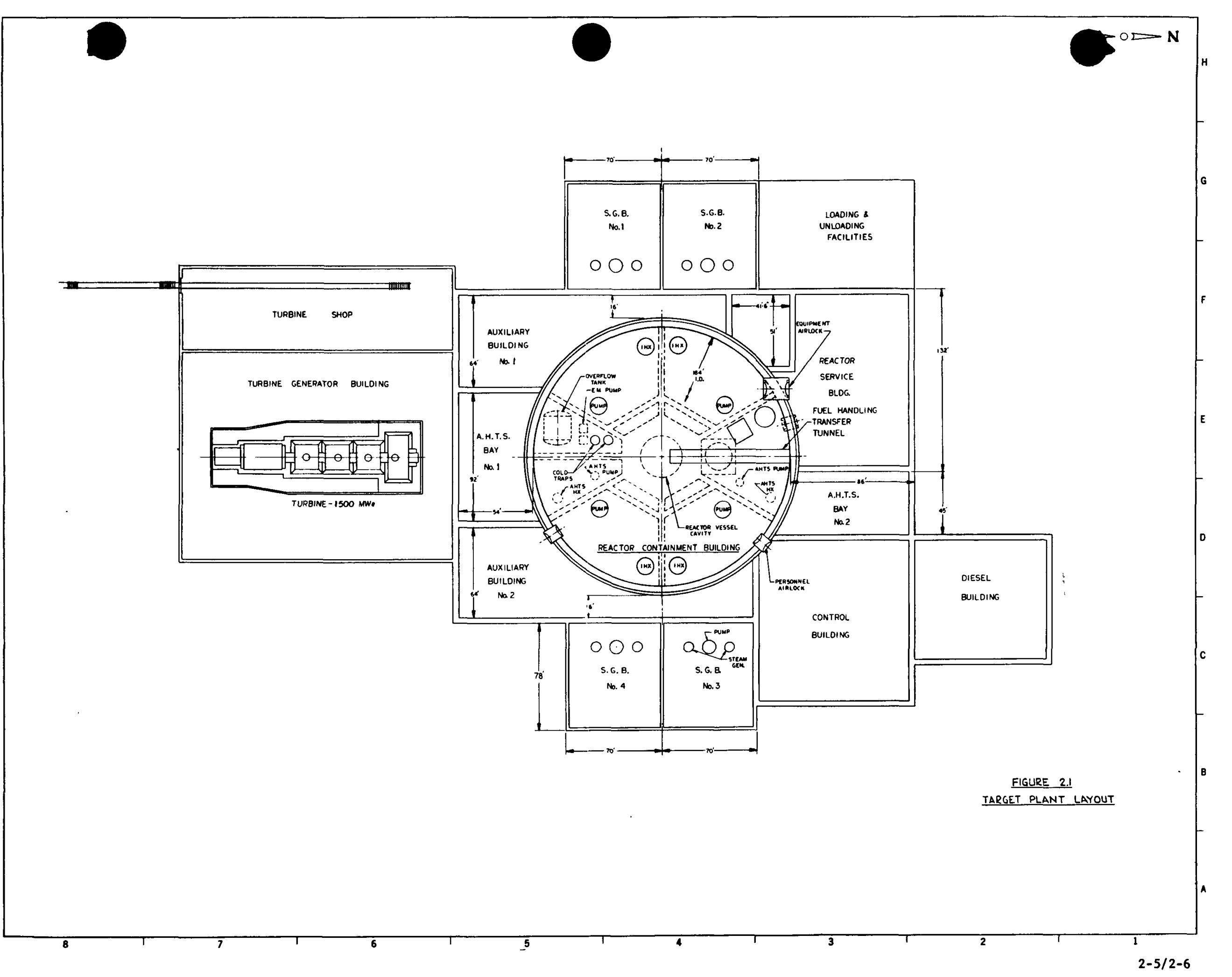




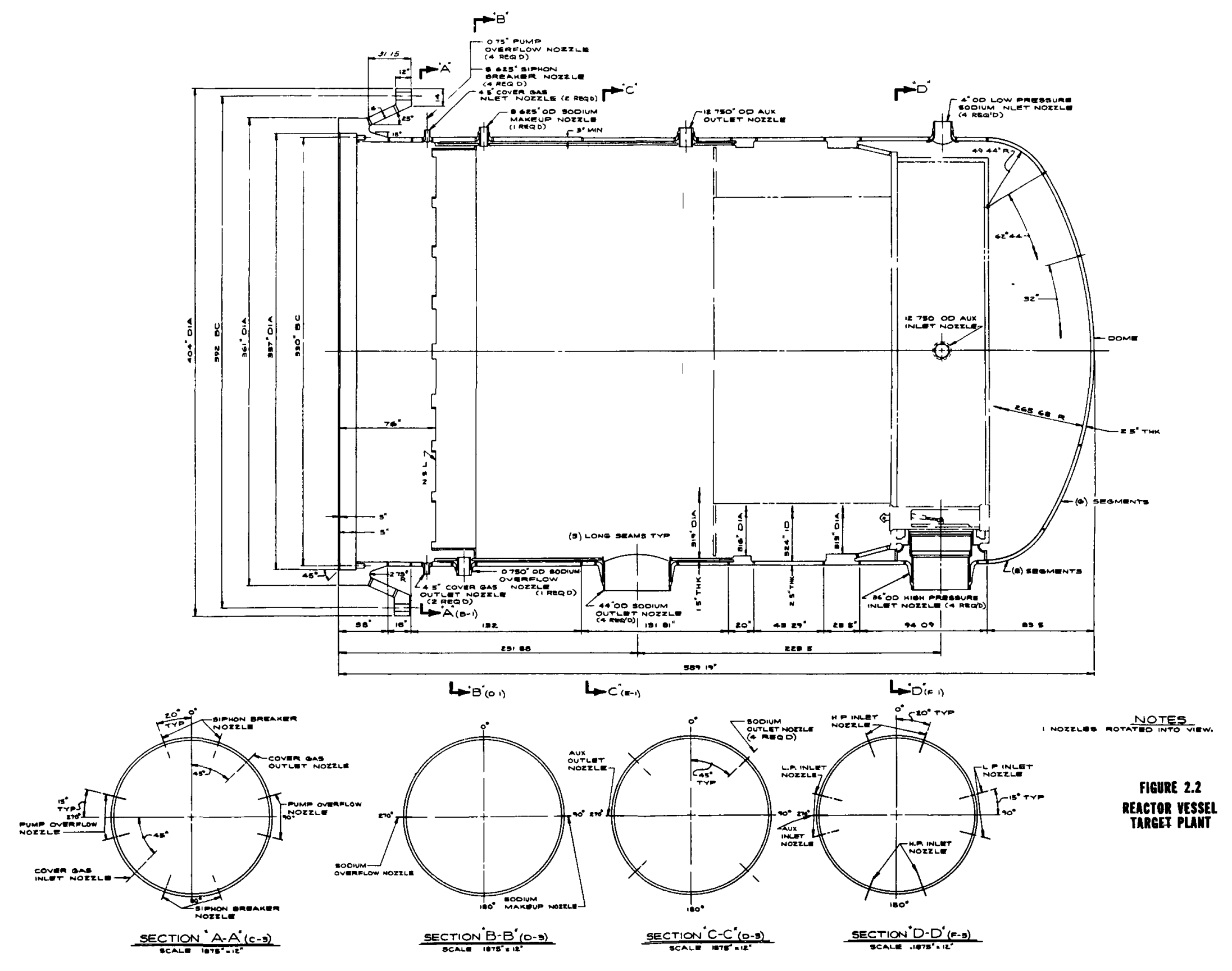


A thermal liner is provided on the upper region of the shell. This liner, which is 1.5 inches thick, extends upward from a point just below the top of the core barrel to an elevation just above the normal operating sodium/cover gas interface. This liner is concentric with the inside diameter of the vessel and provides a stagnant sodium-filled annulus to soften thermal transients and to reduce the radial gradient through the wall. The liner is extended into the nozzles by slip joint designs which allow for relative motions caused by temperature differentials.

The upper flange of the vessel is machined internally to accept and interface with the closure head and also serves as an integral part of the inverted conical skirt vessel support system. A short transition shell course, 18 inches in height, is provided to accommodate the differential thermal expansion between the uppermost shell course of the vessel and the cooler support flange.

There are two other rings found within the reactor vessel weldment. These are located at the lower extremity of the thermal liner and at the core support elevation. (The reactor vessel/reactor internals interface is defined as being at the weld joint at the lower end of the core support cone. The core support, structure, core barrel, and other internals shown in phantom or omitted from the above referenced drawing are described in Section 2.3.1.2 of this report).

Maximum overall dimensions for the reactor vessel are found to be the outside diameter of the support skirt flange which is $33^{\prime}-8^{\prime \prime}$; the outside diameter of the upper and lower shell regions which are $27^{\prime}-6^{\prime \prime}$ and $27^{\prime}-5^{\prime \prime}$, respectively. The inside diameter of the vessel is $27^{\prime}-0^{\prime \prime}$, and the overall length is $49^{\prime}-1.19^{\prime \prime}$. The total dry weight of the vessel is approximately 463 tons.

A11 of the constituent parts of the reactor vessel are made from SA-240, Type 304, stainless steel except for the she11/flange transition course, which is SB-168, the flange, which is SA-508, Class 3, the support skirt and support skirt flange, which are SA-516, Grade 70, and the nozzle forgings, which are SA-182, F-304. 
The vessel is designed and constructed to the requirements of Section III, Class 1 of the ASME Boiler and Pressure Vessel Code for Nuclear application, including Code Case 1592 for high temperature service. Design pressure and temperatures for the inlet and outlet plena are $165 \mathrm{psia} / 675^{\circ} \mathrm{F}$ and 40 psia $/ 975^{\circ} \mathrm{F}$, respectively.

As shown in Figure 2.3, the reactor vessel closure head is composed of four parts: a fixed outer ring (FOR) which is mechanically attached to the reactor vessel flange; a large rotating plug (LRP); an intermediate rotating plug (IRP); and, a small rotating plug (SRP). The four parts are similiar in cross section in that each has a 24.00 inch structural plate (uppermost material thickness), 28.50 inches of graphite blocks, a 4.00 inch lower structural plate, seven (7) 0.125 inch pieces of reflective insulation, and a 0.50 inch suppressor plate (suspended 23.25 inches below the reflective insulation). The graphite blocks are contained within canisters which are attached to the 24.00 inch structural plate.

There are 64 penetrations through the three rotating plugs of the closure head assembly. The following tabulation identifies the penetration types and quantities provided in each of the rotating plugs:

\section{Penetration Type}

Control rod drive and instrument tree housing

Instrument tree housing

In-vessel fuel handling machine

Ex-vessel fuel transfer port

Inlet check valve removal port

\begin{tabular}{|c|c|c|c|}
\hline $\begin{array}{l}\text { Number } \\
\text { in SRP }\end{array}$ & $\begin{array}{l}\text { Number } \\
\text { in IRP }\end{array}$ & $\begin{array}{l}\text { Number } \\
\text { in LRP }\end{array}$ & $\begin{array}{l}\text { Number } \\
\text { in FOR }\end{array}$ \\
\hline 7 & 23 & 0 & 0 \\
\hline 6 & 25 & 0 & 0 \\
\hline 1 & 0 & 0 & 0 \\
\hline 0 & 0 & 0 & 1 \\
\hline 0 & 0 & 1 & 0 \\
\hline
\end{tabular}




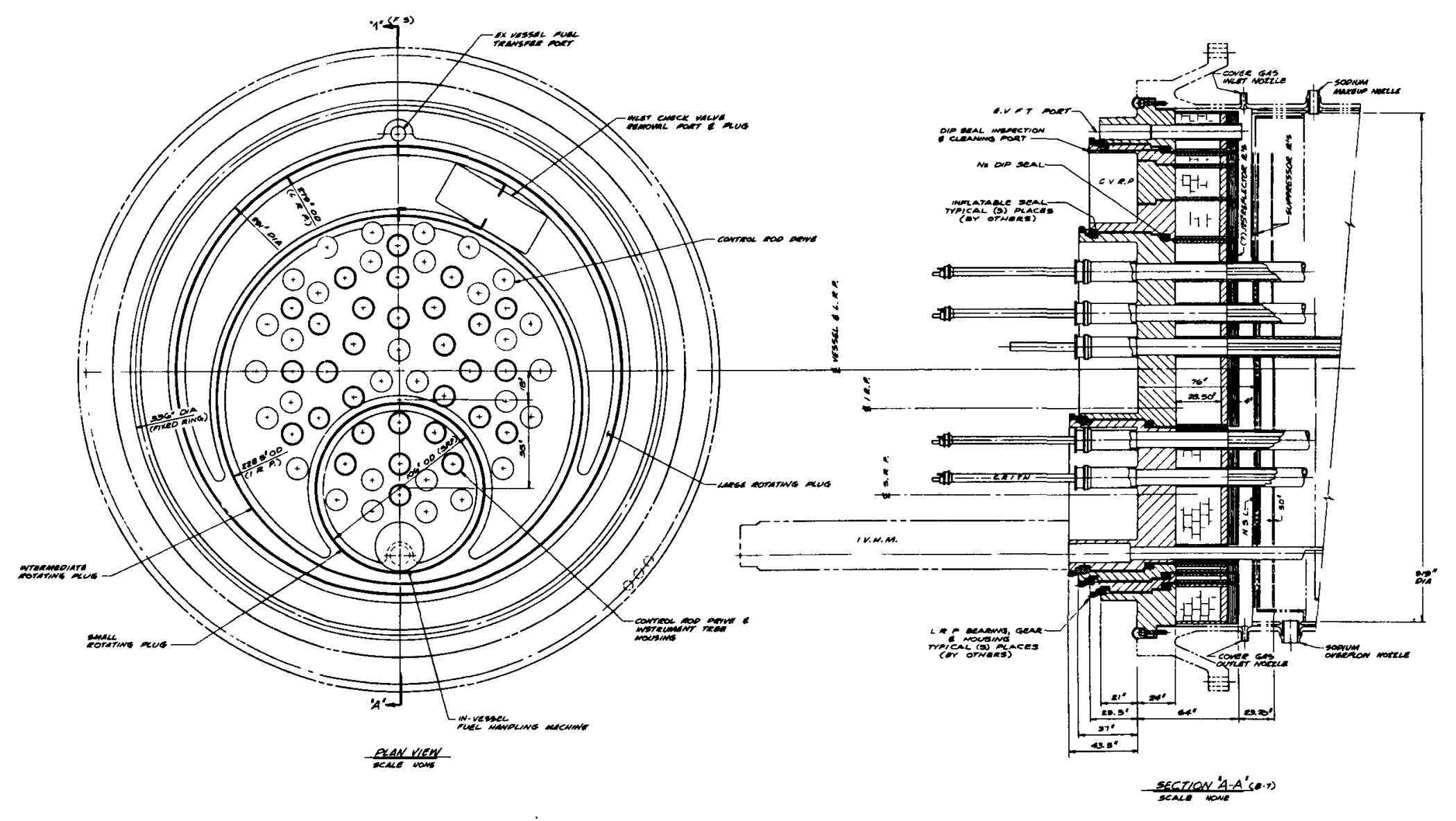

FIGURE 2.3

REACTOR VESSEL GLOSURE HEAD

TARGET PLANT 
The fixed outer ring rests on and is mechanically attached to the reactor vessel upper flange. A welded flexible seal is installed across the vessel flange/outer ring interface to provide a cover gas seal. The large rotating plug is supported on bearings such that it can be rotated within the fixed outer ring. The intermediate rotating plug is supported on bearings within a hole in the large rotating plug. The centerline of the intermediate rotating plug is located 18 inches eccentric from the centerline of the large rotating plug. The small rotating plug is supported on bearings within the intermediate rotating plug. This plug is located 55 inches eccentric from the centerline of the intermediate rotating plug. Thus, the ability to rotate this set of three plugs with their eccentricity to each other and to the vessel affords access to all core assembly locations.

The aggregate weight of the four constituent parts of closure head assembly is approximately 690 tons. The assembly is 28 feet in diameter and measures approximately 11 feet from the bottom of the suppressor plate to the top of the rotational drive extensions.

Materials used in fabricating the closure head are as follows:

$\begin{array}{ll}\text { Upper Structural Plate (24" thickness) } & \text { SA-508, Class } 3 \\ \text { Biological Shielding Blocks } & \text { Graphite } \\ \text { Lower Structural Plate (4" thickness) } & \text { SA240, Type } 304 \\ \text { Shielding Canisters } & \text { SA-240, Type } 304 \\ \text { Reflective Insulation } & \text { SA-240, Type } 304\end{array}$

The closure head is designed and constructed to the requirements of Section III, Class 1 of the ASME Boiler and Pressure Vessel Code for Nuclear Application, including Code Case 1592 for high temperature service. Design pressures and temperatures are $40 \mathrm{psia}$ and $200^{\circ} \mathrm{F}$ for the structural elements and 40 psia and $975^{\circ} \mathrm{F}$ for the insulation. 


\subsubsection{Reactor Vessel Internals}

The reactor vessel internals as shown in Figures 2.4 and 2.5 provide support for the core, flow distribution through the core, and support for instruments and control rod drives.

The core is supported concentrically in the reactor vessel by the core support structure, welded to the vessel wall through a conical skirt. The region directly beneath the core is the high pressure inlet plenum which is connected to each of the high pressure inlet nozzles by a sliding pipe joint. The surrounding space, bounded by the vessel shell and the lower closure head, forms the low pressure plenum. Coolant enters the high pressure plenum through check valves, which are located at each inlet nozzle and can be removed for maintenance. There is also a check valve at each of the inlet nozzles of the Auxiliary Heat Transfer System.

Lateral restraint of the core is provided by the two subassembly support rings. These rings are fabricated in segments to fit the contour of the core at the core component support pads and are held in position by the core barrel, which is in turn attached to the core support structure. The core barrel supports the circular horizontal baffle plates which are welded to the vessel liner at their outer ends.

Suppressor plates, supported by the closure head, are provided directly above the free surface of the sodium to break up the sodium jets emitting from the assembly nozzles. These plates minimize gas entrainment at the sodium surface. An overflow weir at about normal sodium level directs the excess sodium to an overflow nozzle for circulation through a sodium cleanup (cold trapping) system.

A flow shroud, supported on the baffle plates, provides for mixing of the hot sodium before it is directed to the outlet nozzles. Multiple small holes in the shroud provide a high resistance path to the outlet nozzles thus forcing most of the flow over the shroud. 


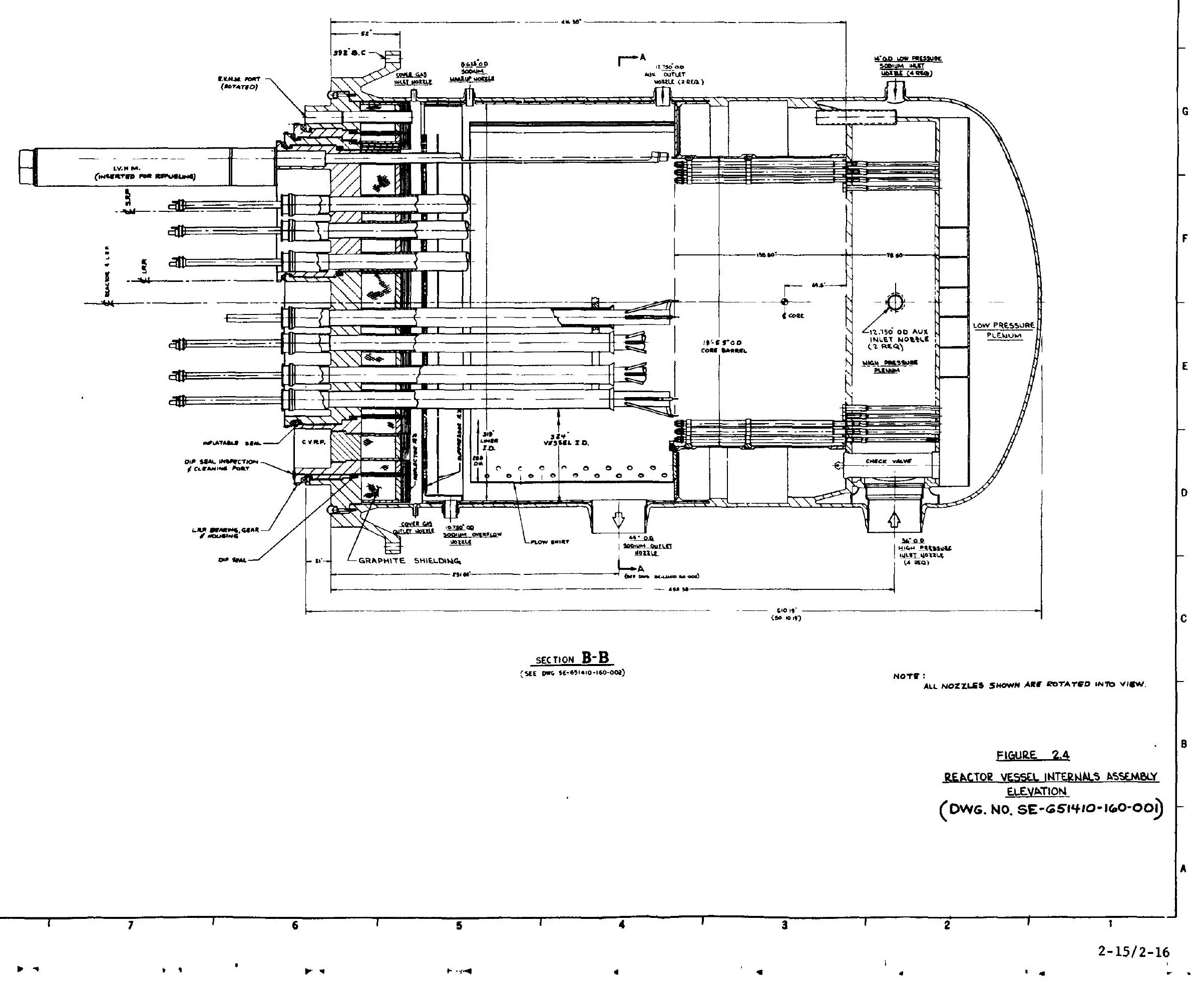




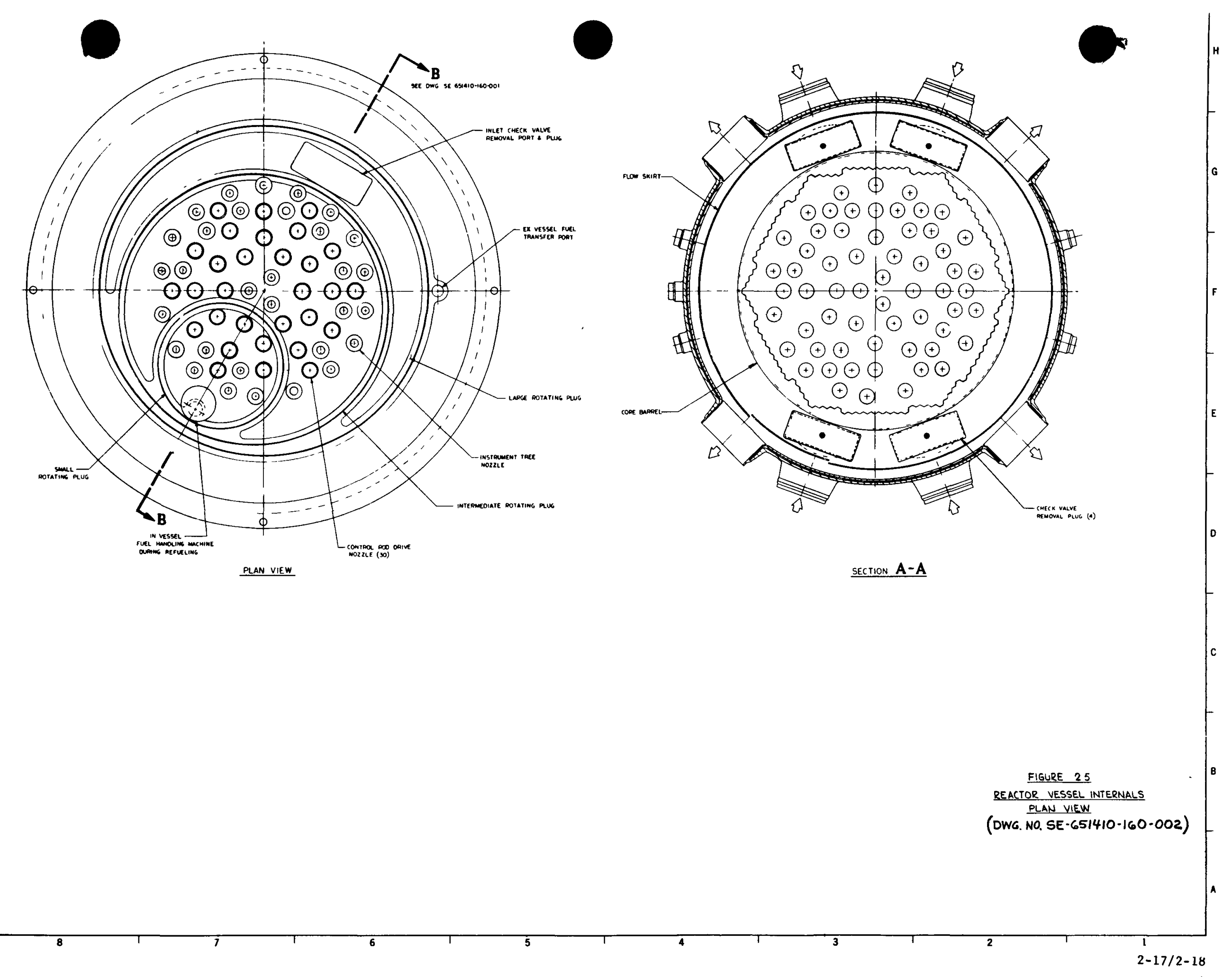


The head is penetrated by 61 control rod guide tubes and instrument nozzles. There are 30 nozzles which guide the safety and shim rod drivers in addition to the core outlet instrumentation. The 31 remaining nozzles are utilized for core outlet instrumentation only. The basic instrumentation consists of an eddy-current flowmeter and redundant thermocouples.

The upper internals of the reactor vessel incorporate 61 control rod and instrument assemblies (CRITA's) a concept developed by C-E. Each CRITA unit, incorporating 19 instrument probes, is a laterally retractable assembly which is removable through the nozzles in the rotating plug. The CRITA performs the functions of monitoring sodium temperature and flow and of mechanical holddown of the core assemblies. A total of 61 CRITA assemblies provide $100 \%$ core coverage.

\subsubsection{Reactor Core}

A summary of the principle reactor parameters is included in Table 2.2. The conceptual design utilizes hexagonal subassemblies with a 6.48 inch lattice pitch. Fuel management is carried out by annual replacement of $1 / 3$ the total core subassemblies to limit the fuel burnup and consequential swelling.

\subsubsection{Cavity Filler System}

The Target Plant cavity filler system provides for reactor vessel enclosure. In the unlikely event of a leak, it contains radioactive sodium and limits the volume available for sodium spills in order to maintain a safe sodium level inside the vessel for continuity of heat removal from the reactor core.

The cavity filler system consists of a carbon steel lined cavity which houses the reactor vessel. The outer periphery of the cavity liner has cooling coils containing heat transfer fluid. These cooling coils limit the concrete temperature during reactor operations. The annular space 


\section{TABLE 2.2}

SUMMARY OF PRELIMINARY PRINCIPAL REACTOR PARAMETERS

Initial Core

1. Number of driver region subassemblies
a. Fue 1
438
b. Control
30
C. Total

468

2. Number of internal blanket subassemblies

3. Number of radial blanket subassemblies

4. Number of radial reflector subassemblies

5. Total number of reactor subassemblies 
between the liner and the reactor vessel is filled with steel-clad graphite filler blocks. Each vertical row of filler blocks is installed on a support column which also acts as a screw lift for removal of the blocks when access for maintenance or inspection is desired. The filler blocks provide shielding and reduce the radioactivity in the adjacent heat transport cells to acceptable levels. A 9-inch insulation and trace heating is integrated in the filler blocks to provide the necessary insulation and heat-up capability, as well as removability for accessibility to the reactor vessel for inspection and maintenance.

The cavity filler system is compatible with in-service inspection of the reactor vesse1, maintenance and/or repair of the reactor vessel and instrumentation, and installation of seismic restraints at critical locations which are accessible for inspection and adjustments. The inside diameter of the reactor cavity is large enough (by $\sim 6^{\prime}$ ) to permit the installation of the reactor vessel with nozzles attached.

\subsubsection{Heat Transport Systems}

\subsubsection{Primary Heat Transport System}

The Primary Heat Transport System (PHTS) of the Target Plant consists of four main heat transport loops of equal capacity, each rated at 950 liwt. Each loop consists of a volute-type centrifugal pump, an intermediate heat exchanger, an isolation valve, an electro-magnetic flowmeter and associated piping. A11 four PHTS loops are symetrically arranged around the reactor vessel in separate steel-lined shielded vaults within the containment building. A schematic diagram for the heat transport system is illustrated in Figure 2.6. 
Primary sodium from the reactor vessel upper plenum is directed to the four outlet nozzles leading to the main heat transport loops. Normal sodium leve 1 in the reactor is maintained by the overflow and make-up systems. The sodium flow in each loop is directed through a hot-leg isolation valve to a double-suction centrifugal pump via a $44 " 0 . D$. Type 316 SS pipe. The pump circulates sodium through a vertically mounted Intermediate Heat Exchanger (IHX) before returning it to the reactor vessel through a 36 " 0.D. pipe.

Before entering the reactor, the sodium flow branches into $36^{\prime \prime}$ O.D. and 14 " 0.D. lines to the high pressure plenum inlet and the low pressure plenum inlet respectively. The low pressure flow passes through a throttling valve, where flow rate is controlled to the reactor inlet nozzles and then directed to the blanket, reflector and control assemblies. Sodium flowing into the high pressure plenum passes through a check valve located within each reactor vesssel inlet nozzle. The main function of the valve is to limit flow reversal in the loop affected by a primary pump failure.

\subsection{Primary Pumps}

A hot leg pump is provided in each of the primary heat transport loops to circulate heated sodium from the reactor vessel to the shell side of the IHX. The primary sodium, cooled by secondary sodium flowing in the tube side of the IHX, is returned to the reactor vessel inlet plenums for recirculation through the reactor core. The primary pumps are located within the Reactor Containment Building.

The primary pump is a double-suction, single-stage, centrifugal pump (Figure 2.7) similar to the one developed by Byron Jackson under DOE/ERDA contract. The pump consists of a stainless steel double-suction impeller with radial suction and discharge, a 12" diameter SS hollow shaft, a 112" diameter SS volute casing and associated bearings and seals. The overall length of the pump is 395" including the shielding, the pump support flange and the driver mount; its weight is approximately 302,000 1bs. The 9000 HP Pump will deliver 87,000 GPM at $375 \mathrm{ft}$. TDH. 
The impeller casing, also made of 304 SS, is voluted for radial suction and discharge. The piped suction with level control allows system operation with low available NPSH (30 ft.) The cover gas is pressurized and automatically controls the sodium level through an overflow line.

The pump is designed and constructed to the requirements of the ASME Code Section III Class I and code case 1592 for high temperature service.

The pump is driven by a 9000 HP AC induction motor which is vertically mounted on the pump with a mechanical coupling to the pump shaft. The axial thrust due to the impeller is taken up by the rotor bearings of the motor. The motor is supplied with a variable freqency supply from a generator driven by a $13.2 \mathrm{KV}$ AC induction motor through a hydraulic coupling. The variable frequency supply to the main motor permits operation of the primary pump at speeds from $40 \%$ to $100 \%$ of the full speed.

A pony motor is also provided and connected to the main motor shaft through a gear box. This allows pump operation with pony motors at $10 \%$ of full flow.

\subsection{Primary Piping System}

The primary piping system maintains sodium flow between the main components of the primary heat transport system (reactor vesse1, IHX's, pumps), in addition to performing siphon, overflow, drain and vent functions. As part of the primary heat transport system, its functional requirements are:

a) to transfer heat generated in the reactor to the secondary heat transport system through the intermediate heat exchanger,

b) to transfer heat generated in the reactor at the temperature and heat rate called for by plant demand,

c) to maintain coolant flow in the reactor core, and 
d) to safely contain activated liquid sodium coolant.

The primary piping system consists of four parallel main coolant circuits. The piping in each circuit consists of a $44 " 0 . D$. Tine from the reactor outlet nozzle through a hot-leg isolation valve to the primary coolant pump, a 36" O.D. line from the pump to the shell side of the IHX, and a $36^{\prime \prime}$ 0.D. line from the IHX through a cold-leg isolation valve to the reactor high pressure inlet plenum. A 14" O.D. line, branching off from this last segment of piping, passes through a throttling valve on its way to the reactor low pressure inlet plenum. 2" vent lines and 6" drain lines are provided at high and low points, respectively, in the circuit. Type 304/316 stainless steel is used throughout the system.

The design of the primary piping system is in accordance with ASME Code Section III Class I. The design temperature and pressure are $950^{\circ} \mathrm{F} / 50 \mathrm{psig}$ for the reactor vessel to pump run, $950^{\circ} \mathrm{F} / 150 \mathrm{psig}$ for the pump to IHX run, and $700^{\circ} \mathrm{F} / 150 \mathrm{psig}$ for the IHX to reactor vessel run. A thermal stress analysis was performed, using the MEC-21 computer program, to ensure that the thermal expansion stresses were within the allowable for each of the primary coolant piping runs.

A11 piping runs for the Primary Heat Transport System are supported at specific locations and restrained against seismic disturbances by mechanical shock and vibration arrestors, also known as seismic snubbers. These snubbers are of the mechanical friction type (non-hydraulic). They allow free movement of the pipe during expansion and contraction of the piping system, but lock up if the pipe moves faster than the design displacement rate along the axis of the snubber.

\subsection{Intermediate Heat Exchanger}

The Intermediate Heat Exchanger (IHX) serves as an interfacial device between the radioactive primary loop and the non-radioactive intermediate loop. Thus, the IHX's are placed within the containment building with the reactor vessel to isolate the radioactive sodium. There is one IHX per loop i.e., four IHX's per plant. 
The IHX receives primary sodium from the hot outlet plenum of the reactor vessel through the hot leg primary pump. This fluid enters the shell side of the IHX through an inlet plenum located around the upper region of the tube bundle. After having passed through a perforated distribution cylinder, the sodium enters the shell side of the tube bundle and flows downward giving up heat to the cooler intermediate sodium which is flowing through the tubes. The primary sodium exits the tube bundle at the lower end of the unit by flowing outward and through the concentric annulus formed by the she11 and lower tubesheet periphery. After having passed between the lower floating head and the outer head of the IHX, the sodium exits through the IHX outlet nozzle and is returned to the high pressure plenum of the reactor vessel.

Intermediate sodium is supplied to the IHX from the steam generators by the cold leg intermediate pump. This flow of relatively cool sodium enters the IHX through an insulated downcomer. This downcomer extends downward through the central region of the tube bundle to a lower floating head which serves as an inlet plenum to the tube side of the component. As the intermediate sodium flows upward through the tubes it receives heat from the counterflowing primary sodium. After emptying into the upper head region of the IHX, the heated secondary fluid exits the IHX and is piped to the steam generators.

As shown in Figure 2.8, the IHX design is a vertically oriented, top supported, centerflow heat exchanger featuring the higher temperature primary sodium on the she11 side and the lower temperature intermediate sodium on the tube side. The design provides for differential thermal expansion between the shell and tube bundle by having the lower tubesheet and head keyed to the shell such that it is restrained only in the horizontal direction. A bellows is provided to accommodate relative axial motion between the tubebundle and downcomer. 

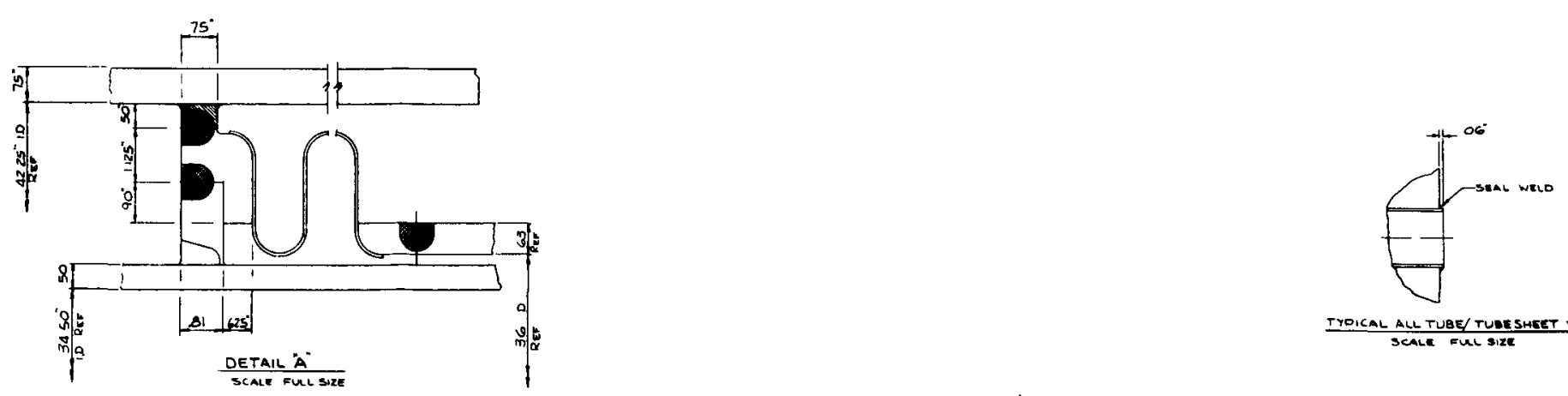

TYOICAL ALL TUBE/TUAESHEET WELOS

(641) OVERALL LeNert

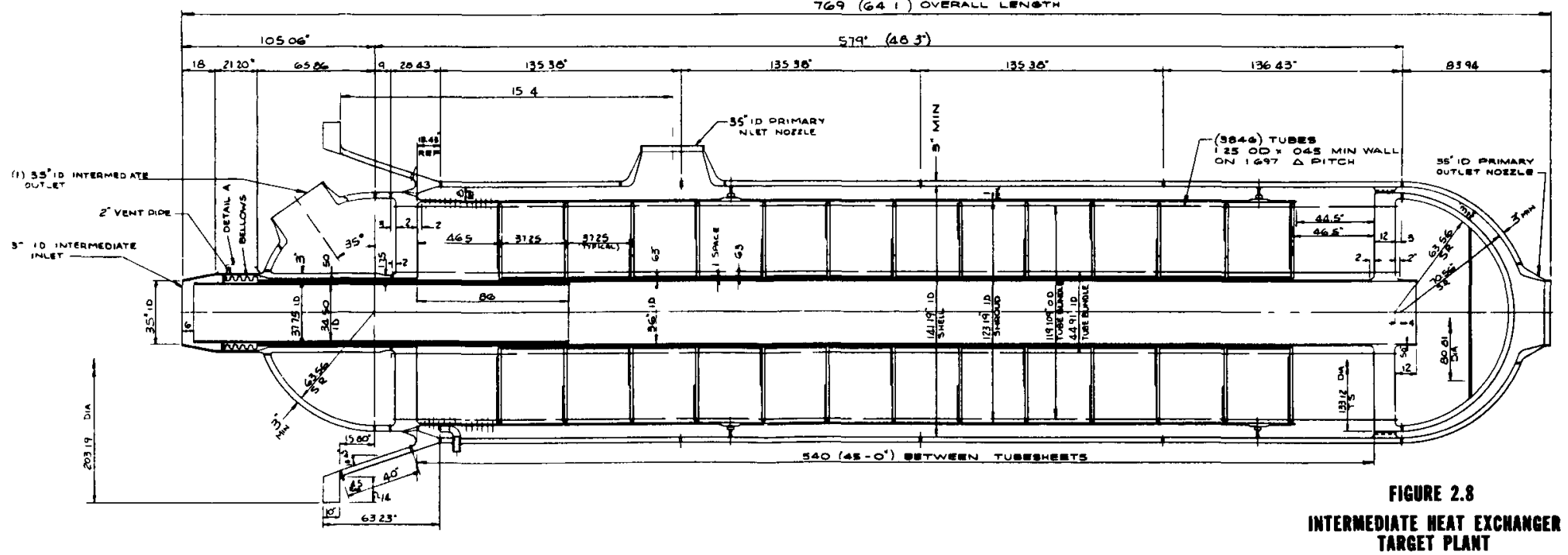

TAREET PUANT 
A11 shel1 plate thicknesses, including the hemispherical heads, are 3.00 inches. The shell has four major nozzles: one intermediate sodium inlet, one intermediate sodium outlet, one primary sodium inlet, and one primary sodium outlet. These nozzles are of a common 35.00 inch inside diameter size. Other pertinent material thicknesses are the inner and outer flow shrouds which are 0.63 inches and 1.00 inches, respectively; the central downcomer and thermal liner (located in the upper region of the downcomer) which are 0.63 inches and 0.50 inches, respectively; the two tubesheets which are 12.00 inches; and, the support skirt and support flange which are 3.00 inches and 10.00 inches, respectively.

The tube bundle is comprised of 3,846-1.25 inch outside diameter tubes positioned in a triangular array on 1.697 inch centers. Tube wall thickness is 0.045 inches and the heated length is 45 feet. Thus the total heat transfer area is $56,600 \mathrm{ft}^{2}$ per IHX. There are thirteen eggcrate type tube supports located on 37.25 inch centers. Plates are added to the eggcrate tube supports to yield a disc and doughnut flow effect. Tube-to-tubesheet welds are of a rolled and seal welded design.

The vessel is designed and constructed to the requirements of Section III, Class 1, of the ASME Boiler and Pressure Vessel Code, including Code Case 1592 for high temperature service. Design pressure and temperature for the IHX are $165 \mathrm{psia}$ and $975^{\circ} \mathrm{F}$, respectively. The primary sodium enters the unit at $950^{\circ} \mathrm{F}$ and exits at $650^{\circ} \mathrm{F}$. Primary and intermediate side flow rates are $35.8 \times 10^{6}$ and $33.4 \times 10^{6} 1 \mathrm{bm} / \mathrm{hr}$, respectively. The IHXs are designed as 950 Mwt units.

Materials for the IHX are as tabulated below:

Plate Material

Tubing

Tubesheets and Nozzles
SA-240, Type 304

SA-213, Type 304

SA-182, Type F304 
The dry weight of an IHX is approximately 320 tons. Maximum diameters are the support skirt flange which is 203.19 inches and the component she11 which is 147.19 inches. The overall length of the IHX is 64' l'.

\subsubsection{Intermediate Heat Transport System}

The Intermediate Heat Transport System (IHTS) consists of four identical sodium loops (Figure 2.6) required to transport reactor heat from the Intermediate Heat Exchanger to the Steam Generating System. Each 1oop has a rated capacity of $950 \mathrm{Mwt}$. The secondary loops contain non-radioactive sodium which is circulated by a secondary sodium pump from the tube side of the IHX through the shell side of the steam generators and back to the IHX.

The secondary sodium flow is completely isolated from the radioactive primary sodium by the IHX tube walls which provide a mechanical barrier. In addition, the secondary sodium pressure within the IHX is maintained above the shell side (primary) sodium pressure, so that in the event of a tube leak, radioactive sodium will not enter into the secondary system; this provides a backup barrier. Each loop is comprised of one single stage centrifugal pump, an expansion tank, sodium piping leading to and from the IHX and the steam generators.

The secondary sodium from the IHX is routed through a $36^{\prime \prime} 0 . \mathrm{D}$. pipe from the reactor containment building into the steam generator building. The flow is split and directed to the combined unit steam generators through $26^{\prime \prime}$ 0.D. pipes. After exiting the steam generators, cooled sodium flows through two parallel 26" 0.D. Tines before recombining into a single 36" 0.D. line leading to the sodium pump inlet. The pump is a vertical, singlestage centrifugal pump designed to deliver $76,700 \mathrm{gpm}$ of sodium with a rated head of 300 feet. From the pump discharge sodium flows into $36^{\prime \prime} 0 . D$. piping to complete the circuit through the IHX.

Electro-magnetic flowmeters in the cold leg downstream from the pump provide flow rates for control and plant protection. Venturi meters (in two loops only) provide the flow measurements required in the instrumentation of the steam generators. 
An expansion tank in each loop accommodates sodium volume change due to thermal expansion over the operating range. The expansion tank is located in the steam generator building near the corresponding sodium pump. The expansion tank is interconnected to the pump tank as well as to the high point of the steam generators and the IHX.

As shown in Figure 2.9, the Secondary Sodium Expansion Tank is a verticallyoriented top-supported cylindrical vessel closed at both ends by an elliptical head. All plate stock used within the weldment, including material for the two heads is of a constant 2.53 inch thickness. The vessel wall is penetrated by one 16.00 inch manway and seven small diameter nozzles. Except for short elbowed pipe extensions on three of the nozzles, the vessel has no internals.

Physically, the vessel has an overall length of 191.63 inches and shell and flange outside diameters of 123.25 inches and 150.00 inches, respectively. The total dry weight of the vessel is approximately 24 tons.

The vessel is fabricated using 304 SS material for all plate stock and the flange forging. The expansion tank is designed to the requirements of Section VIII, Division 2, of the ASME Boiler and Pressure Vessel Code. Design pressure and temperature are $300 \mathrm{psia}$ and $600^{\circ} \mathrm{F}$, respectively.

For coolant purification, air-cooled cold traps in the cold leg of each loop remove inpurities. Each loop has similar components and maintains equal flow. Piping configurations within the steam generator cell is identical for all the loops.

\subsubsection{Steam Generator System}

The steam generator system (SGS) reliably and safely provides superheated steam $\left(850^{\circ} \mathrm{F}\right.$ at $\left.2200 \mathrm{psig}\right)$, suitable for the turbine-generator system by transferring heat from intermediate sodium to water/steam in the steam 
generators. The SGS also provides redundant decay heat removal paths subsequent to a reactor shutdown. The SGS consists of the following subsystems:

(1) Steam generator subsystem

(2) Sodium/water reaction relief subsystem

(3) Leak detection subsystem

(4) Sodium dump subsystem

(5) Water dump subsystem

\subsection{Steam Generator Subsystem}

The steam generator subsystem transfers reactor-generated heat from the intermediate sodium to the water/steam in the steam generators and delivers steam to the turbine at a rate dictated by load demand and reactor operating conditions.

There are four steam generator subsystems corresponding to four IHTS loops. The steam generator subsystem for each loop consists of two steam generators, associated piping and valves. The heated sodium from the IHX is divided into two streams; one to each steam generator. Feedwater from the condenser, after being heated in the feedwater heaters, enters the steam generators, boils and is heated to superheated steam conditions. The steam from the steam generators is routed to the high pressure inlet of the turbine.

The steam generators are counterflow, shell and tube, single-wall heat exchangers. They are installed at an elevation higher than the IHX to promote natural circulation in case pumping power is lost. This arrangement provides for decay heat removâl subsequent to a reactor shutdown and loss of power. 


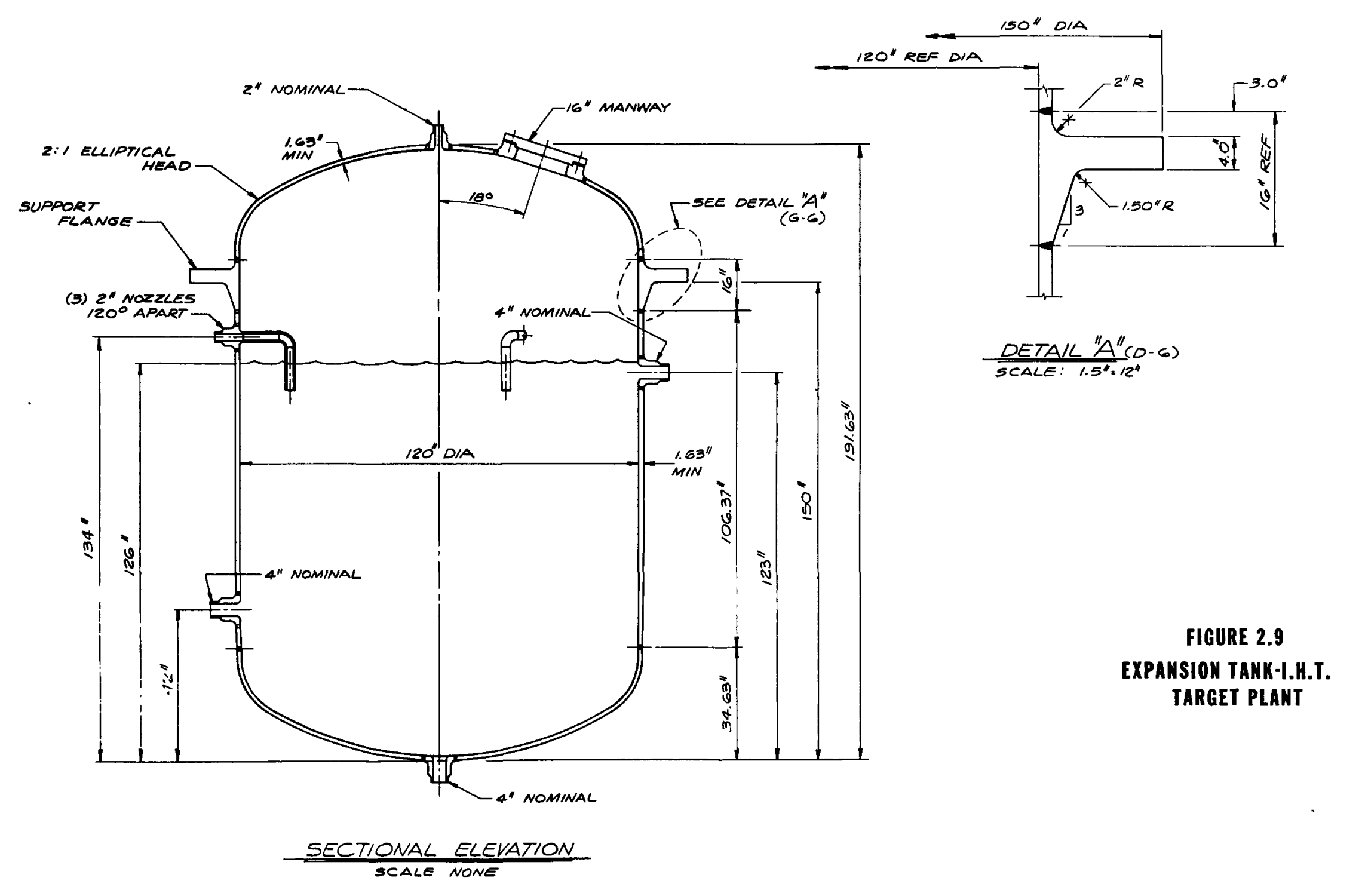


The steam generator represents a critical link in the LMFBR System. This component not only transforms the heat extracted from the reactor core into steam for rotating the turbines, it also serves as the interfacial device between the sodium and water loops. Even though the sodium which passes through the steam generator is non-radioactive, a fajlure in the pressure boundary could result in a violent exothermic chemical reaction which occurs when sodium and water are mixed. For this reason, the steam generator must exhibit a high degree of design and structural integrity.

Being in the non-radioactive portion of the 1oop, the steam generators may be located outside the reactor containment building. There are two steam generators per loop or eight per plant.

Hot sodium from the intermediate heat exchanger enters the shell side of the steam generator through an upper distribution plenum. After flowing upward through an orifice plate, the sodium enters the tube bundle and flows downward giving up heat to the water/steam which is flowing within the tubes. The spent sodium then exits the tube bundle through the outlet plenum to be returned to the IHX.

Feedwater enters the steam generator through a hemispherical head at the lower end of the component. As the sub-cooled liquid begins its upward flow through the tube bundle, it begins receiving heat from the counterflowing sodium and is thus heated to the boiling state. As it continues the upward passage through the tube bundle, it receives additional heat and is eventualiy dried out and superheated prior to exiting the steam generator. The superheated steam leaves the component through a floating outlet plenum.

As shown in Figure 2.10, the steam generator design is a vertically-oriented, top supported, counterflow heat exchanger featuring the higher temperature intermediate sodium on the she11 side and the lower temperature water/steam on the tube side. The unit is a once-through combined unit in that it receives feedwater at $470^{\circ} \mathrm{F}$ through the waterside inlet nozzle and provides superheated steam at $854^{\circ} \mathrm{F}$ through the steam outlet nozzle. The 
steam outlet pressure and flow rate is $2200 \mathrm{psig}$ and $1.78 \times 10^{6} 1 \mathrm{bm} / \mathrm{hr}$. The design provides for differential thermal expansion between the she11 and tube bundle by having the upper tubesheet and steam outlet plenum keyed to the shell such that it is restrained only in the horizontal direction. A bellows is provided at the upper extremity of the shell to provide a flexible containment for the sodium. As shown in the Figure, the bellows joint features a mechanically attached protective housing which also serves as a back-up seal.

The vessel shell thickness is 1.50 inches throughout the cylindrical portion of the vessel except for the uppermost shell course which is 2.50 inches. The upper hemispherical head, which completes the sodium containment, is also 1.50 inches thick. There are four nozzles opening through the sodium she11: two 25.00 inch ID nozzles for sodium inlet and outlet; and, two 24.00 inch ID nozzles which are utilized as access ports during the steam generator tubing operation. Thermal liners are provided on the sodium side at the tubesheets and on the shell in the inlet and outlet regions. A 1.00 inch flow baffle is fitted as tightly as possible around the outside diameter of the tube bundle. The upper and lower tubesheet thicknesses are 26.00 inches and 23.00 inches, respectively, and the waterside inlet and outlet hemispherical heads are 5.00 inches and 5.50 inches, respectively. The feedwater inlet nozzle is sized for compatibility with 10 inch Schedule 160 pipe and the steam outlet nozzle for 14 inch Schedule 160 pipe. In both cases, mechanically attached flanges are provided to permit access to the waterside of the tubesheets.

The tube bundle consists of 35470.75 inch outside diameter by 0.125 inch wall tubes located on 1.250 inch centers in a triangular array. The tube bundle heated length is $72^{\prime}-0^{\prime \prime}$, thus each of the eight steam generators has a total heat transfer area of 50,145 $\mathrm{ft}^{2}$. There are $20 \mathrm{drilled}$ plate type tube supports located along the length of the tube bundle. Flow holes are sized in such a way as to simulate disc and doughnut type flow. Tube-totubesheet welds are of a front side, back side configuration as shown in detail on the above referenced figure. This type of design provides a highly reliable crevice-free joint which enhances the overall reliability of the unit. 


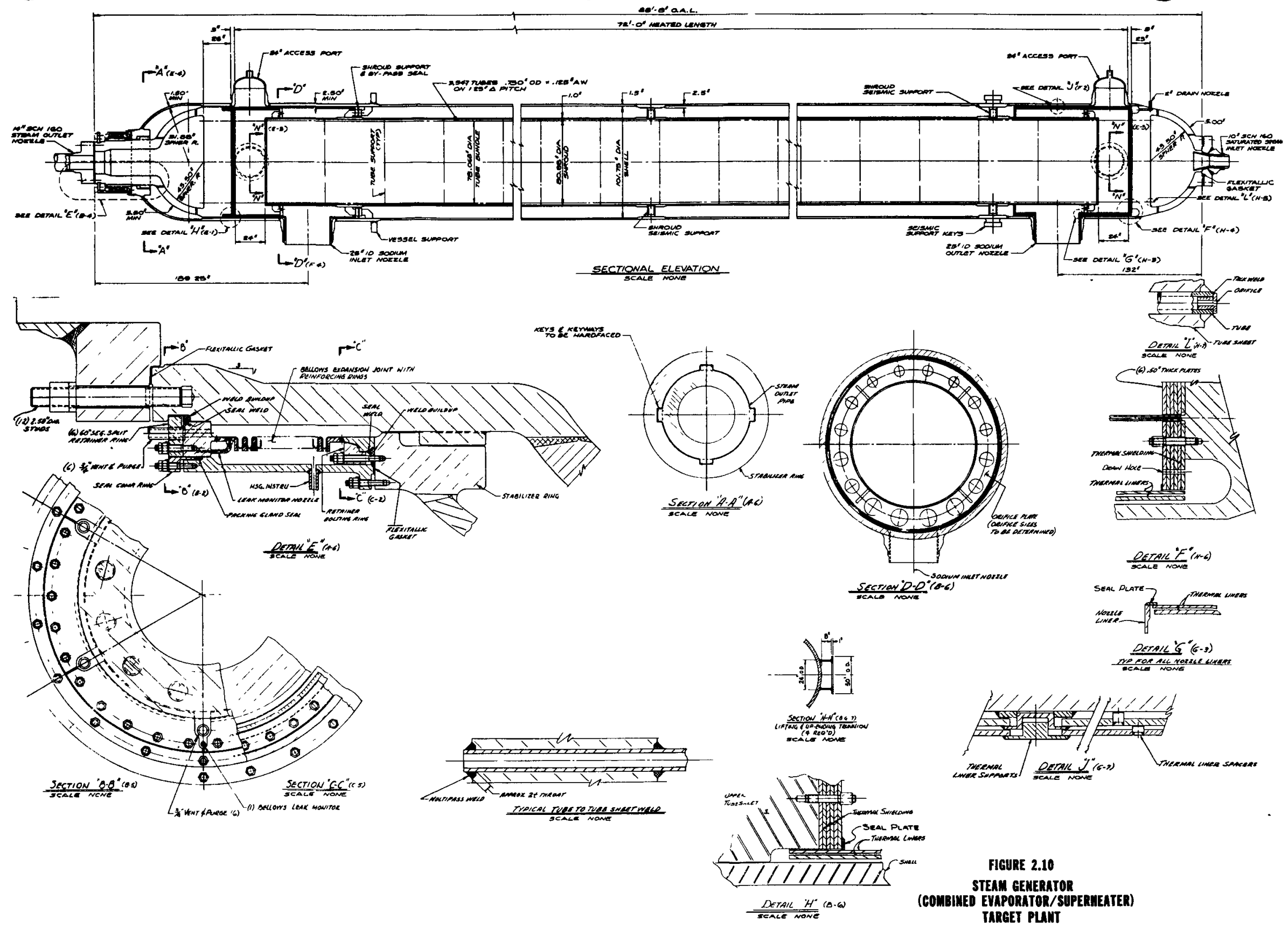


The vessel is designed and fabricated in accordance with Section VIII, Division 2 of the ASME Boiler and Pressure Vessel Code. The design pressure and temperature for the shell side of the component is $300 \mathrm{psia}$ and $935^{\circ} \mathrm{F}$, respectively. The $16.7 \times 10^{6} \mathrm{lbm} / \mathrm{hr}$ of sodium enters the steam generator at $910^{\circ} \mathrm{F}$ and exits at $590^{\circ} \mathrm{F}$. The waterside flow rate, temperatures, and pressure are as stated above. Each steam generator is designed as a 475 Mwt unit; thus, two steam generators are fed from one 950 Mwt IHX.

Materials for construction for the steam generators are as follows:

Shell Plate

Tubesheets

Tubes
SA-387, Gr. 22, C1. 1

SA-336, F22

SA-213, Gr. T22

The maximum diameter of the steam generator shel1 is 106.75 inches, and the overall length is $88^{\prime}-8^{\prime \prime}$. The total dry weight of a single component is approximately 325 tons.

\subsection{Sodium/Water Reaction Relief Subsystem}

The steam generator sodium/water reaction relief subsystem is provided to prevent overpressurization of the Intermediate Heat Transport System and the IHX which would lead to failure of the primary coolant boundary. The overpressure protection is provided by means of rupture discs designed to rupture at a preset pressure. The rupture discs are installed in lines leading to a separator tank. Subsequent to a large sodium/water reaction, the pressure pulse due to the reaction bursts the rupture discs and the sodium/water reaction products along with some sodium are routed to a separator tank. In the separator tank the hydrogen is centrifugally separated from liquid sodium and reaction products and flared through a stack. The liquid sodium from the separator tank is drained to a drain tank for disposal and/or cleanup. 


\subsection{Leak Detection Subsystem}

The steam generator leak detection subsystem consists of hydrogen detection units installed on the bypass lines from the steam generator units to the expansion tank. The bypass stream flow rate is set to facilitate quick detection of a sodium/water reaction, identification of the leaking unit and appropriate protective actions, e.g., isolation and quick dump from the water and/or sodium side of the steam generators.

\subsection{Sodium Dump Subsystem}

The sodium dump subsystem functions to limit the consequences of a sodium/water reaction in the steam generators by a quick dump of the sodium into sodium storage tanks. The system consists of piping and valves suitably located to ensure sodium drain from the loop affected by a large sodium/water reaction. The sodium storage tanks, which are part of the auxiliary liquid metal system, have adequate capacity to ensure complete evacuation of the affected loop.

\subsection{Water Dump Subsystem}

The water dump tanks provide for the water/steam dump subsequent to a leak in the steam generators. Quick-close isolation valves provide evacuation of any unit without affecting the operational status of other loops.

\subsubsection{Auxiliary Heat Transfer System}

Two Auxiliary Heat Transfer Systems (AHTS) with maximum capability of removing 57 Mwt each (1.5\% of full power), are provided to satisfy the plant requirements for independent and redundant means of decay heat removal from the reactor. They each consist of a primary and secondary loop (Figure 2.11) for ultimate heat rejection to air. 


\section{$\bullet$}

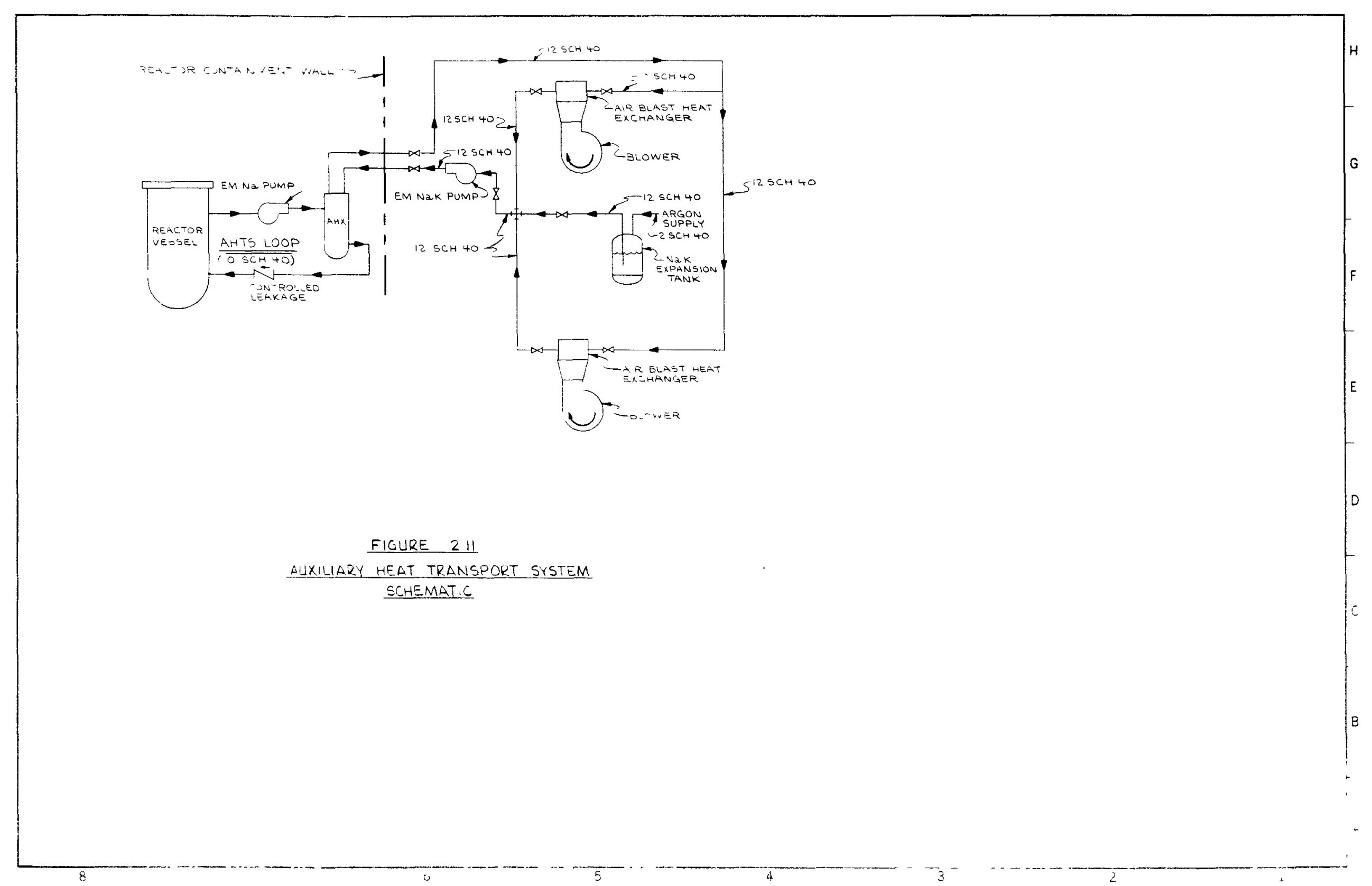


Radioactive primary sodium is circulated by means of a hot-leg flat linear induction electromagnetic pump to an Auxiliary Heat Exchanger (AHX), where heat is transferred to the secondary coolant (NaK) circulating in the tube side of the AHX. The primary sodium is then returned to the high pressure plenum of the reactor vessel. The secondary loop using a cold-leg flat linear induction electromagnetic pump circulates NaK from the AHX to two FFTF-type Forced Air Heat Exchangers (FAHX), where heat is rejected to the atmosphere.

The primary 10op, wholly contained within the reactor containment building, is enclosed within a system of guard pipes and guard vessels to limit the quantity of sodium leakage. In the event of a leak, a minimum sodium level is maintained in the reactor vessel for continuity of heat transfer. The secondary loop is located within a seismic Category I, tornado and missile protected building and is maintained at a higher pressure than that of the primary sodium to preclude any outleakge of the radioactive primary sodium.

A check valve, with an orifice in the valve disk, is provided in the line between the AHX and Reactor Vessel to limit the reverse flow through the system to about $100 \mathrm{gpm}$ to maintain the primary loop of the AHTS at about the reactor inlet temperature. This is to 1 imit the thermal transients imposed on the system when AHTS operation is initiated.

By provision of independent and redundant decay heat removal systems, i.e., two AHTS cooling systems, the secondary HTS and Steam Generator Systems (SGS) are not required to perform decay heat removal functions. Therefore, the non-radioactive secondary HTS and SGS, associated components and structures may be designed and constructed to commercial standards.

\subsubsection{Fuel Handling and Storage System}

An area of major impact on the total plant availability and, hence, importance to the purchasing utility, is the system for refueling the reactor. Since 
approximately 280 fuel, blanket and absorber assemblies must be replaced annually for the Target Plant, a strong incentive exists to hold refueling time down to 1.0 hour per subassembly, giving 10-20 days for refueling. C$E$ has developed a modified EBR-II type arrangement which can achieve this target (Figure 2.12).

A conceptual design of a refueling system utilizing this concept is described below. The concept features:

1 - A straight pull in-vessel handling machine.

2 - A triple rotating plug system.

3 - A transfer arm and in-vessel elevator to minimize the vessel size.

4 - A method of exchanging core components that allows the in-vessel and ex-vessel portions of the refueling system to operate simultaneously.

5 - A transfer tunnel for movement of fuel between the reactor vessel and the ex-vessel storage tank that does not breach the containment boundary during handling of core components.

6 - A limited function ex-vessel handling machine for efficiency.

7 - A system of air locks (valves) that minimizes danger of accidental discharge of radioactive material in the event of an accident.

With this system, an In-Vessel Handling Machine (IVHM) mounted atop the inner of three eccentric rotating plugs transfers individual subassembiies to a position above the outermost radial reflector assembly. When a new fuel assembly is lowered by elevator to the same elevation at the periphery of the reactor vessel, a double-ended transfer arm is rotated $90^{\circ}$ to engage and lock onto the handling socket of both new and spent assemblies on 


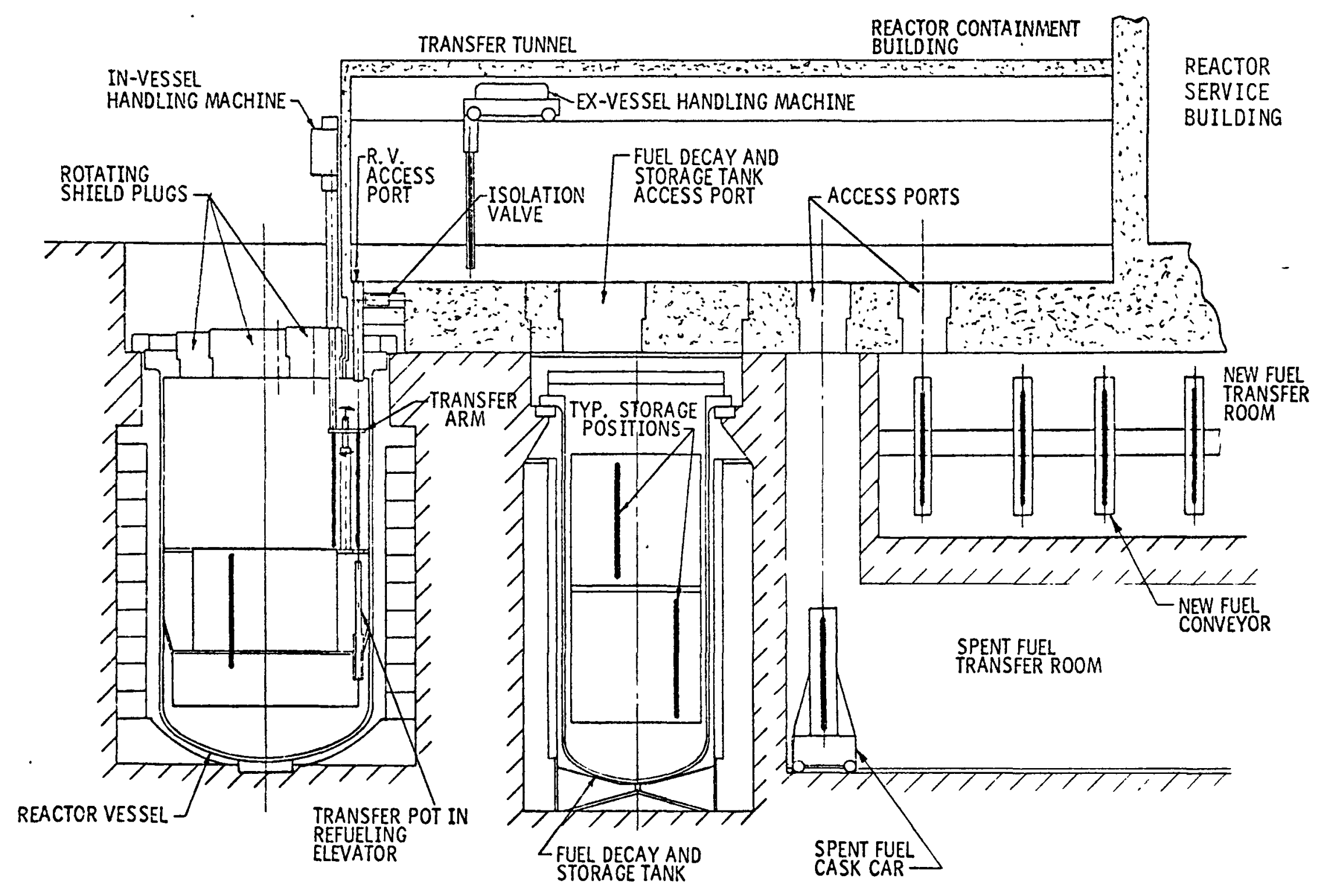

FIGURE 2.12

REFUELING SCHEME 
opposite ends. At this time, the IVHM disengages from the spent assembly and the ex-vessel transfer pot is lowered by a ba11/screw elevator mechanism below the new assembly. The transfer arm is thus clear to rotate 180" and permit exchange of the assemblies.

The transfer pot, positioned under the spent assembly, is raised by the elevator to contain the spent assembly; the IVHM locks onto the handling socket of the new assembly. The transfer arm is then disengaged and rotated $90^{\circ}$ to permit insertion of the fresh assembly and removal of the spent assembly via the transfer pot from the vessel.

The Ex-Vessel Handling Machine (EVHM) is mounted on tracks in a shielded tunnel above the operating floor. During refueling, it shuttles between the vessel head transfer port and the decay storage transfer port exchanging spent and new assemblies. Before refueling, it receives new assemblies after appropriate examination and preheating for insertion in the decay tank. After a sufficient decay period, the EVHM removes the spent assemblies for drying and loading into shipping casks for transport to a processing facility.

Key features of this fuel handling method are its simplicity, and the simultaneous handling of new and spent assemblies by IVHM and EVHM equipment.

The reactor Refueling System provides the means for storing, transporting and handling core components within the Reactor Plant. The following components are defined as core components:

1. Core fuet assemblies

2. Radial blanket assemblies

3. Control assemblies 


\section{Removable radial shield assemblies}

Of the new core assemblies arriving at the Target Plant, only the new fuel core assemblies require shielding and criticality control. In the interest of simplicity of procedure because fuel assemblies make up the majority of the components replaced, one uniform system and procedure is utilized for al1 core component handling. Irradiated core components require shielding and decay heat removal. Irradiated core components containing fuel also require criticality control and containment of fission gas, in the event of leaks in fuel rods.

The refueling system is made of the following major subcategories: fuel handling equipment; special tools and service equipment; cranes, hoists and shipping casks; storage and transfer facilities. The following list defines the major subcategories of the refueling system:

\subsubsection{Fuel Hand7 ing Equipment}

This category includes:

1. In-vessel handling machine (IVHM)

2. Transfer arm (TA)

3. Refueling elevator

4. Ex-vessel handling machine (EVHM)

5. Transfer pots (TP)

6. New fuel conveyor 


\subsubsection{Special Tools and Service Equipment}

This category includes special purpose lifting and handling fixtures, adapter equipment, shielded valves and seal plugs for use at access ports, removal containers for use in replacing or removing the IVHM on the rotating shield plugs, and special equipment that may be required to determine the status of equipment in inaccessible locations.

\subsubsection{Cranes, Hoists, Carts and Shipping Casks}

This category includes general purpose cranes and hoists within the reactor building and in the fuel handling building. Included in this category are the shipping casks and cask carts.

\subsubsection{Storage Facilities}

Covered under this category are the ex-vessel storage tank, new fuel storage vault and the ancillary equipment required for proper operation.

\section{Ex-Vessel Storage Tank}

The Ex-Vessel Storage Tank (EVST) used for this study is esentially the same as that designed for use in the Clinch River Reactor Plant. Minor dimensional and tolerance changes were assumed for the purpose of this study and the guard tank was omitted.

The Ex-Vessel Storage Tank (EVST), as shown in Figure 2.13 is actually comprised of three components: a Storage Vessel, a Closure Head, and a Turntable Assembly. These three components are described as separate entities with concluding paragraphs which describes how the parts are assembled. 
The Storage Vessel is a vertically oriented, top supported, cylindrical vessel with a lower elliptical head. Except for the uppermost shell course, the pressure boundary has a constant thickness of 1.50 inches. The uppermost shell course is 3.00 inches thick. The vessel wall is penetrated by a number of small diameter nozzles to provide for the control of cover gas and the removal of heat generated by the fuel elements stored within the vessel. There is a flow distribution plenum in the lower head of the vesse1. The vessel flange is machined internally to accept the turntable bearings and on the upper surface to support and seal with the closure head.

Maximum overall dimensions for the vessel are the outside diameter of the flange which is 279.00 inches; the cylindrical shell outside diameter which is 236.00 inches; and the overall length of the vessel which is $59^{\prime}-2$ ". The dry weight of the vessel is approximately 210 tons.

Construction materials for the vessel are SA-240, Type 304, for the shell and lower head and SA-508, Class 2, for the support flange.

The vessel is designed and fabricated to the requirements of Section III, Class 2, of the ASME Boiler and Pressure Vessel Code for Nuclear Application.

Referring again to Figure 2.13, the Closure Head is similar in crosssection to the Reactor Vessel Closure Head. It has a 12.00 inch upper structural member from which insulation canisters are suspended. Thermal insulation is afforded by twenty-five 0.063 inch shielding plates stacked on spacers such that gas spaces separate the plates.

The head is made up of two major parts: a fixed outer ring, and a fixed central cover. Plated " $C$ " rings are utilized for sealing at both the vessel/outer ring interface and at the outer ring/central cover interface. There are nine access ports through the head which permit withdrawal and insertion of the elements into the storage positions of the turntable. These ports are arranged to align with the concentric array of storage positions within the turntable. 


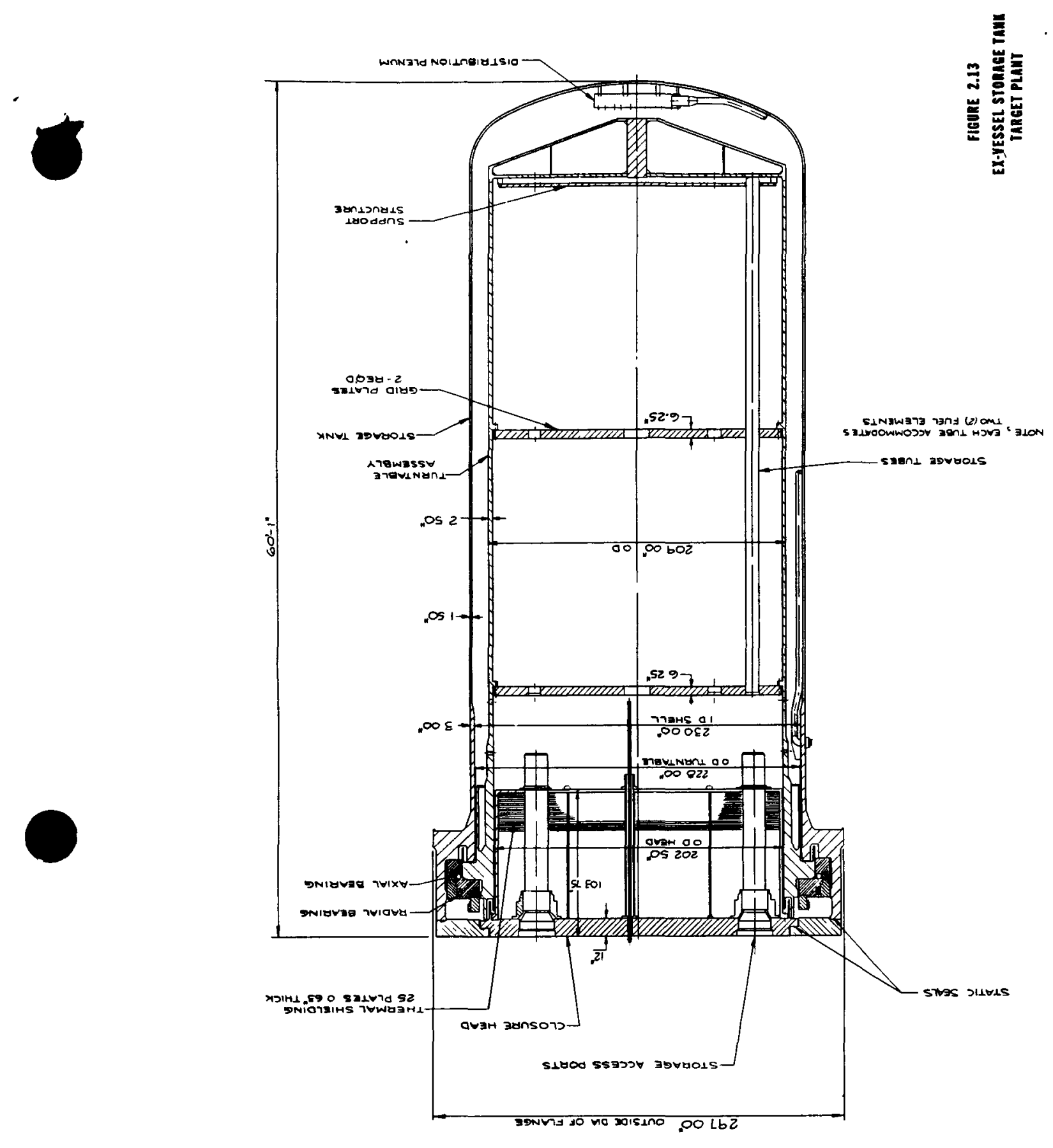


The physical size of the head is defined by the 294.00 inch outside diameter, the 103.75 inch height (including the insulation canister); and, the total assembled weight of approximately 150 tons.

Materials of construction for the closure head are SA-240, Type 304, for the insulation material and canisters and SA-633, Grade B, Class 1, for the 12.00 inch structural plate.

The closure head is designed and fabricated in accordance with the requirements of Section III, Class 2, of the ASME Boiler and Pressure Vessel Code.

The turntable assembly is perhaps the most complicated component of the EVST. It can be described as a vertically-oriented cylindrical structure which provides support for and defines the location of the fuel storage tubes. The upper flange of the turntable assembly is machined to rest on bearings within the upper vessel flange.

The outer wa11, or structural member, of the turntable is 2.50 inches thick throughout most of the component length. A cylindrical skirt is attached in the flange region and extends downward. This skirt is closely machined to fit the inside diameter of the storage vessel to facilitate sodium frost removal. The lower end of the component is closed by a flat support structure weldment which has flow holes to permit the passage of sodium up through the fuel storage tubes. There are two 6.25 inch grid plates located as shown in the figure at intermediate elevations within the turntable assembly. The two grid plates and the support structure provide accurately located holes for supporting the storage tubes.

The turntable assembly has a total weight of approximately 246 tons, is 56 feet long and the $f 1$ ange and outer wall diameters are approximately 226 and 209 inches, respectively. It is manufactured entirely from SA-240, Type 304 , steel and is designed and fabricated in accordance with the requirements of Section III of the ASME Boiler and Pressure Vessel Code. 
Referring again to the above referenced figure, the turntable is suspended within the vessel on bearings. Thus, after the closure head has been installed, the turntable can be rotated within the stationary vessel/closure head assembly. A drive mechanism is provided such that the turntable can be indexed to a known position. Thus, after the correct access port plug has been removed, access is provided to all the storage positions within the turntable.

\subsubsection{Inert Gas System}

The inert gas receiving and processing system consists of the following subsystems:

Argon Distribution Subsystem (ADS)

Nitrogen Distribution Subsystem (NDS)

Radioactive Argon Processing Subsystem (RAPS)

Cel1 Atmosphere Processing Subsystem (CAPS)

\subsubsection{Argon Distribution Subsystem}

The Argon Distribution subsystem provides cover gas to all liquid metal free surface areas, including inflatable and buffered head seals. The system provides the required inert atmosphere to the liquid metal containers for draining, purging or filling these containers. The argon gas itself is also cleansed of any oxide impurities. Separate systems are provided for the primary and intermediate sodium systems.

The radioactive ADS is supplied by gas bottles stored in the Reactor Service Building and supplies argon via a header arrangement to the EVS sodium system, the reactor vessel head seals, primary cold traps, the primary sodium storage tank, and the fuel handling systems. Recycled argon from the RAPS is introduced into the primary ADS from which it is distributed to the reactor vessel and to the sodium pumps and overflow vessel. 
The intermediate system ADS is supplied by gas bottles stored in the steam generator buildings. A header arrangement distributes fresh argon to the intermediate system at the intermediate expansion tank and the intermediate sodium dump tanks. Since this gas is not radioactive, venting to the a tmosphere is done via an oil bubbler.

Primaiy and intermediate systems have the same general component makeup with the exception that the primary argon discharge goes to a radioactive cover gas header for processing by the RAPS. The major components include argon gas bottles, vaporizers, argon filters, sampling packages, relief vents, vapor traps, freeze vents, feed-bleed valves, and the associated piping.

\subsubsection{Nitrogen Distribution Subsystem}

The Nitrogen Distribution Subsystem (NDS) functions primarily to provide an inert atmosphere and thus reduce the sodium-air reaction problems in case the liquid sodium coolant escapes its designed pressure boundaries. The system also provides cooling for the various cells containing radioactive sodium or sodium vapors. Additionally, the NDS provides a cover gas to the radioactive liquids produced by the RAPS.

Cold traps and other regenerative heat exchangers such as those in the RAPS use nitrogen as the cooling gas. In some instances, the nitrogen may be processed in the RAPS if it becomes radioactive.

Nitrogen stored in the containment building is used to inert primary and auxiliary loop heat transport cells, inert the EVST cell, furnish nitrogen to the CRITAS, and provide cooling in liquid form for the RAPS.

Nitrogen stored in the steam generator building is used as a cover gas to Dowtherm tanks for servicing the sodium components cleaning facility, and to provide the capability for inerting steam generator cells in the event of a sodium water reaction. 


\subsubsection{Radioactive Argon Processing Subsystem (RAPS)}

The RAPS system removes radioactivity, due mostly to fission gases, from argon and returns clean argon to a storage tank for recycling through the plant systems. The contaminated argon from the reactor vessel, overflow tank, primary pumps, cold traps, isolation valves, fuel storage tank, and fuel handling equipment flows through vapor traps, filters, delay tanks, charcoal adsorbers and a distillation column for removal of radioactive impurities (Figure 2.14). Clean argon is returned to a storage tank for redistribution to the plant systems. The vapor traps located near the sodium components remove the sodium vapor and the particulates are removed in the on-line absolute filters. Delay tanks provide for decay of short lived isotopes and the gaseous fission products are removed in charcoal beds by adsorption and in the distillation column by liquidification. The clean argon, containing less than $10^{-5} \mu_{j} / c c$ radioactivity, is returned to the storage tank for recycle. The system is sized to provide for argon recycle which may be necessary in case of reactor operation with $1 \%$ fuel failure. The nominal argon flow rate is 8 SCFM whereas the maximum flow rate is 25 SCFM to provide for normal and abnormal requirements for cover gas purification.

A part of the argon stream coming from the distillation column is mixed with contaminated argon flowing to charcoal columns to provide for desired flow and density distribution between argon and radioactive contaminants. The pressure of clean argon in regenerative heat exchangers is maintained above the pressure of the contaminated argon to prevent any contamination of clean argon. Except for some piping connections, most of the radioactive argon processing system is contained within the Reactor Service Building.

\subsubsection{Cell Atmosphere Processing Subsystem}

The Cell Atmosphere Purification Subsystem (CAPS) is essentially a second gas purification system ensuring that effluent gases released from the plant will have radioactivity levels as low as practicable. The usual 

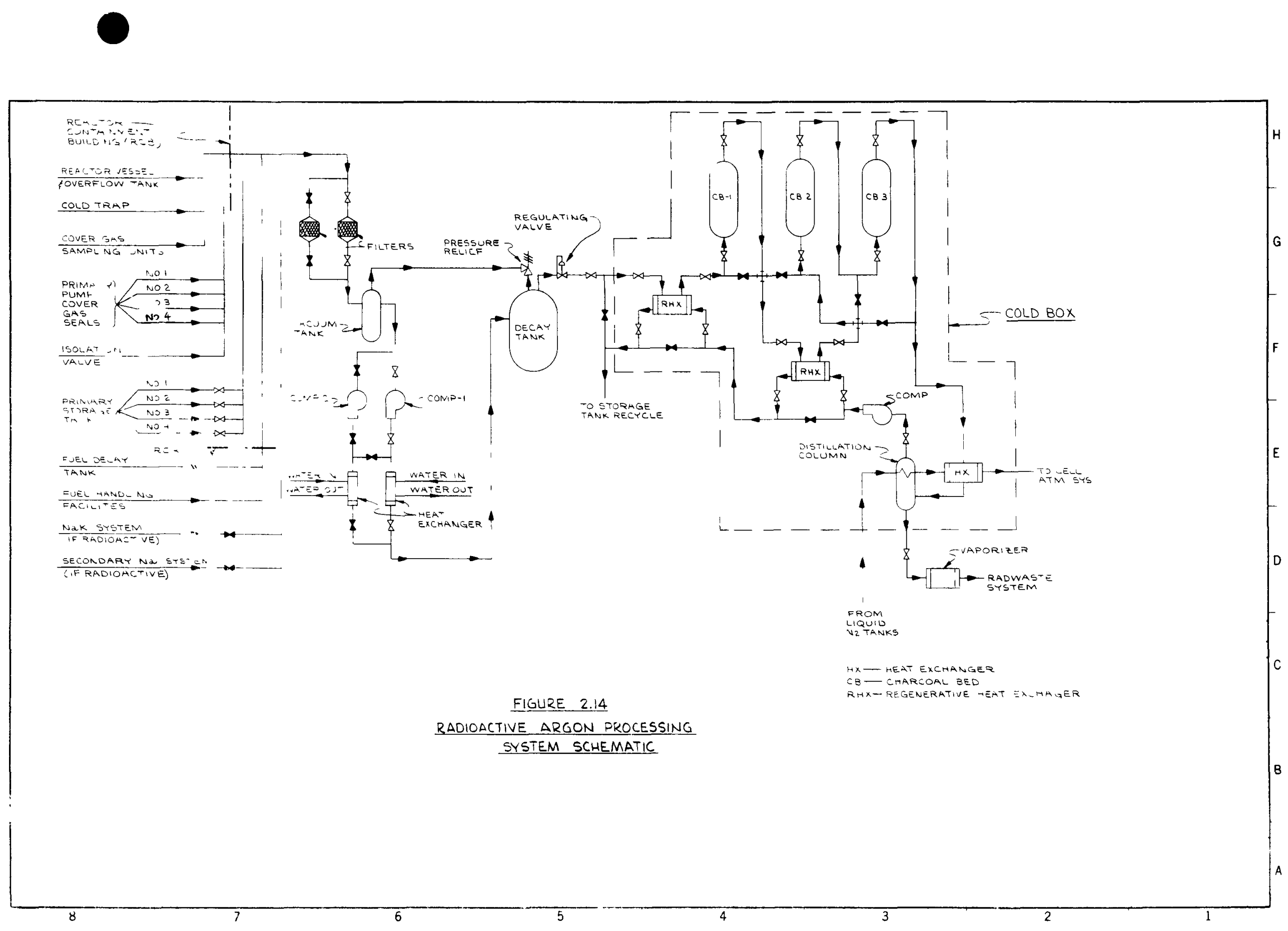
inputs to CAPS are nitrogen used to inert the various cells, low level radioactive argon cover gas from the intermediate systems, and effluents from atmospheric vents located throughout the plant. The normal function of this system is to remove tritium from the air and nitrogen prior to release to the plant exhaust.

Vapor Traps

Vapor traps in the argon piping are located near the sodium components to minimize the length of trace heaters between the trap and the component. The vapor trap is a vertically mounted shell and tube heat exchanger with air or $\mathrm{N}_{2}$ blowers. Hot cover gas enters at the bottom of the shell and is cooled by cell air or $\mathrm{N}_{2}$ which is blown counter-current through the tubes. Sodium vapor is condensed on the tube surfaces. Resistance heating elements are provided to melt sodium for draining as required.

\section{Particulate Filters}

Particulate filters are provided to remove any particulate material which may pass through the vapor traps. These filters are cylindrical vessels containing stainless steel filter elements which can be replaced by remote methods.

Vacuum Tank

This carbon steel vessel has 4000 gallons capacity and is rated at 150 psig at $120^{\circ} \mathrm{F}$. The vesse 1 is approximately $7^{\prime}-0^{\prime \prime}$ diameter by $14^{\prime}-0^{\prime \prime}$ and is installed with its longitudinal axis in a horizontal plane. This vessel is connected to two compressors rated average at 8 SCFM and maximum of 25 SCFM. The vessel provides sufficient volume to allow for one compressor to reduce the vessel pressure from -2 psig to -7 psig in 20 minutes of operation. 
Cold Box

The cold box consists of a series of charcoal columns, regenerative heat exchangers and a distillation column. Radioactive argon is cooled in the regenerative heat exchanger, and is passed through charcoal beds. Heavy isotopes, i.e., Krypton and Xenon, are retained in the charcoal by absorption, whereas the relatively clean argon flows to a distillation column. Liquid $\mathrm{N}_{2}$ cools the gases in the distillation column, liquefying radioactive impurities in argon which are delivered to the radwaste system. Clean argon from the distillation column is heated in regenerative heat exchangers and pumped to a storage tank for recycling through the system.

\section{Compressors}

The compressors are 25 SCFM units designed for radioactive gas service. These compressors are used to pump argon to the RAPS surge and delay tank. The compressors are located in the Reactor Service Building in cells which have sufficient shielding to allow maintenance of one compressor while the other is operating. The minimum compressor inlet pressure is $-7 \mathrm{psig}$ and maximum discharge pressure is +135 psig.

Surge and Delay Tank

This carbon steel vessel has 7200 gallon capacity and is rated at 150 psig pressure at $120^{\circ} \mathrm{F}$. The vessel is approximately $7^{\prime} 0^{\prime \prime}$ diameter by $25^{\prime}$ long and is installed with its longitudinal axis in a horizontal plane. The vessel provides a hold-up time of a minimum of 4 hours.

Charcoal Absorber Beds

The Argon Processing System utilizes 3 charcoal beds. These charcoal beds are located in the cold box in the Reactor Service Building. Each bed is approximately 3 feet in diameter and 8' 1ong. The beds will be operated at temperatures down to $-290^{\circ} \mathrm{F}$ and have a design pressure of $150 \mathrm{psig}$. The 
charcoal columns have the axial line in vertical position to ensure uniformity of flow and charcoal compactness. The radioactive argon gas enters the column at the bottom and leaves the bed via the nozzle at the top of the column.

Cryogenic Distillation Column

A cryogenic distillation column is used in the Radioactive Argon Processing System to remove $99.9 \%$ of the Krypton and $99.99 \%$ of Xenon. These removal factors are necessary to reduce the effluent activity to less than $10^{-5}$ ${ }_{\mu} C_{j} / c c$. Also the above removal factors are approximately the maximum.

Cold argon near its saturation temperature enters near the bottom of the packed distillation column and rises up through the packing. The vapor is constantly scrubbed by reflux liquid argon flowing down through the column which extracts the Krypton and Xenon from the vapor phase. The resulting clean argon passes through the top of the column while the Krypton and Xenon collect as a liquid in the bottom of the column. Liquid nitrogen provides the refrigeration for the column but does not come into direct contact with argon, thus maintaining argon purity.

Xenon/Krypton Vaporizer

This vaporizer in the argon processing system is an air-to-liquid heat exchanger used to vaporize the argon/Xenon/Krypton mixture when it is periodically removed from the bottom of the distillation column.

\subsubsection{Auxiliary Liquid Metal System}

The Auxiliary Liquid Metal System provides the facilities for receipt, storage, and purification of all liquid metals used in the plant. The system consists of the following subsystems:

- Sodium Loading and Unloading System 
- Primary Sodium Overflow and Makeup System

- Primary Sodium Purification and Storage System

- Ex-vessel Storage Tank Sodium Processing System

- Intermediate Sodium Purification and Storage System

- NaK Storage and Purification System

\subsubsection{Primary Sodium Overflow and Makeup System}

The reactor overflow and makeup circuit operates continuously during reactor operation to maintain a constant sodium level in the reactor by accommodating volumetric changes in the primary sodium due to temperature variations. During operation, sodium overflows from the reactor vessel by gravity to the primary sodium overflow tank. The primary sodium makeup pumps continuously pump sodium from the overflow tank to the reactor vessel at a constant makeup rate of $350 \mathrm{gpm}$. The overflow rate varies during system transients but is equal to the makeup rate during steady state operation of the plant systems. The makeup requirement corresponding to a load variation which results in $\pm 3.5^{\circ} \mathrm{F} /$ minute change in sodium temperature is $312 \mathrm{gpm}$. Thus, the makeup rate of $350 \mathrm{gpm}$ ensures that maximum makeup requirements are met to maintain a constant sodium level in the reactor vessel. Two electromagnetic pumps each having $100 \%$ capability are provided to ensure redundancy and reliability.

The overlfow tank size $\left(20^{\prime} \times 25^{\prime}\right)$ is based on the expansion of primary sodium from $400^{\circ} \mathrm{F}$ (refueling temperature) to design temperature $\left(950^{\circ} \mathrm{F}\right.$ ). A 700 gallons margin is included for possible secondary Na leakage into primary sodium. A $20 \%$ margin is reserved for gas volume in the overflow tank. 


\subsubsection{Primary Sodium Purification System}

The primary sodium purification system, as illustrated in Figure 2.15, consists of three $100 \%$ capability NaK-cooled sodium cold traps installed in parallel to each other and to the primary sodium makeup line. The makeup pumps take suction from the overflow tank and deliver sodium to the reactor vessel. Part of this flow is directed to the cold traps for sodium cleaning and impurity control. Normally, only one cold trap in operation is required during plant operation to maintain the primary sodium purity level to required specifications, but during refueling when the inleakage may be larger than normal, all three cold traps could be pressed into service to maintain sodium purity.

\subsubsection{Primary Sodium Storage System}

Eight storage tanks, two per 10op, are provided for the Target Plant primary sodium storage. Each storage tank is sized to accommodate complete drainage of a PHTS 10op. A 10\% margin is provided for cover gas volume.

Drain connections with isolation valves are provided at low points of the PHTS to provide for complete drainage of primary sodium by gravity to the overflow tank.

\subsubsection{Ex-Vessel Storage Tank Sodium Processing System}

The Ex-vessel Storage Tank (EVST), which provides for storage of spent fuel subassemblies and other reactor components, is located below the floor in the Reactor Containment Building. The EVST sodium processing system controls the temperature and purity of the sodium contained in the EVST.

The EVST sodium cooling system has two independent cooling circuits, each consisting of a sodium electromagnetic pump, a sodium-to-NaK heat exchanger, a NaK electromagnetic pump, a Nak-to-air forced-air heat exchanger and associated piping and valves. Each circuit is sized to remove about 3.5 Mwt heat, estimated to be the maximum decay heat load due to radioactive 
components in the storage tank. The two cooling circuits are supplied by the essential bus, and redundancy, independence and reliability of the cooling circuits are assured. The sodium pumps are rated at $980 \mathrm{gpm}$ for $100 \mathrm{ft}$. of total developed head. One of the primary storage tanks provides for drainage of the EVST as well as for any sodium makeup requirements.

The EVST purification system consists of two 100\% capacity purification circuits. Each circuit consists of one regenerative heat exchanger, a NaKcooled sodium cold trap (rated at $100 \mathrm{gpm}$ ) connected in parallel to each of the EVST cooling circuits. Only one cold trap circuit is required for maintaining normal purity of sodium with an EVST inventory turnover of about 10 hours. During fuel handling, however, both the cold traps are pressed into service to provide for cleanup.

\subsubsection{Equipment Heating and Temperature Control System}

A11 pipes, tanks, heat exchangers, and other equipment containing sodium must have heating systems for preheating and melting the sodium which is solid below $208^{\circ} \mathrm{F}$. This heat is required to preheat sodium systems prior to fill, to prevent sodium freezing and to maintain preestablished temperature differences in the systems. To perform the heat-up function, the heating system must be capable of preheating the sodium systems from ambient temperature $\left(70^{\circ} \mathrm{F}\right)$ to any temperature between ambient and a maximum of $400^{\circ} \mathrm{F}$ at a rate of $3^{\circ} \mathrm{F} / \mathrm{hr}$, before the system is filled with sodium. This heating is done over a long period of time and at a very slow heat-up rate (four to six days) in order to minimize temperature differences within the sodium process system.

The heating systems use forced circulation of heated nitrogen and electric resistance heaters. The forced nitrogen circulation is used in conjunction with trace heating to preheat vessels, component internals and cavities before the systems are filled with sodium. The second method (trace heating) is utilized to provide the applicable heatup rate for the particular system or components when filled with sodium, and to hold system temperatures when filled with sodium during prolonged shutdowns. 
These heaters are arranged, grouped and controlled in zones of uniform heat output. Temperature sensing devices (thermocouples) monitor each zone and provide the necessary feedback for power level adjustment in the heaters. The heater physical mounting arrangement and associated hardware must be designed to prevent damage to the component being heated and not to impair the ability of the components to perform their safety function. The heaters are of a resistance type consisting of a single spiral wound nickel-chromium alloy resistance wire insulated from its Inconel or stainless steel tubular sheath by tightly packed magnesia powder. Several inches on each end of each heater are unheated having a heavy lead-out conductor to the electrical termination.

The heaters stand off from the sodium containing metal boundary for the safety-related piping and components. For the nonsafety-related components, the heaters may be applied directly in contact with the sodium containing metal boundary. Shorting of heater elements to the heater sheath is prevented by insertion of ground current detection and interrupting devices in the heater circuits. Heater redundancy is provided where failure could cause undesirable thermal stresses, or where access for heater replacement is restricted. Reliability is improved by operating the heaters at half their rated power. They may be operated above half power should additional heat output be required.

Depending on the application the power to the heaters may be controlled by manual switches, solenoid-operated contractors, transformers or triacs. The use of the above circuits is dictated by heat requirements such as infrequent heat, routine load, constant load or fast changing heat output. Chromel-alumel thermocouples Type " $K$ " are used throughout the sytems for monitoring the temperature of the metal boundary of the sodium containing components. Signals are relayed to the data handling and display system, where the input is fed to the controllers and recorded in the data handling and display system. 
Electric heaters are provided for all piping and equipment containing sodium or sodium vapors. Some applications, such as storage tanks, may require electric heat continuously during all phases of plant operation. other applications, such as main heat transport systems, require heat only at startup and during shutdowns.

The major systems requiring heaters, temperature sensors and instrumentation are listed below:

Reactor System

Reactor Refueling System

Primary Heat Transport System

Intermediate Heat Transport System

Steam Generator System

Auxiliary Heat Transfer System

Auxiliary Liquid Metal Systems

Inert Gas Receiving and Processing System

Sodium Impurity Monitoring System

\subsubsection{Instrumentation and Control System}

The Instrumentation and Control System for the Target Plant consists of the following subsystems:

- Data Processing System

- Safety Systems

- Control Systems

- NSSS Process Monitoring Systems 


\subsubsection{Data Processing System}

The Data Processing System is a digital-computer-based data system which is used to monitor, analyze and record the plant data used for evaluation of plant performance. Essentially all other control systems provide input signals to the Data Processing System. The System performs no control or safety function and is used to fulfill the following primary functions:

\section{(1) Reactor core thermal/hydraulic map \\ (2) Fuel burnup calculations, Fuel Management \\ (3) Reactivity worth and control rod calibration}

(4) Heat balance calculations

(5) Performance calculations of key components, e.g. pumps, IHX, Steam Generators

The plant operator communicates with the system via pushbuttons which permit him to call up data for display or printout. Permanent data records are stored on magnetic tape for subsequent recall and analysis.

\subsubsection{Safety Systems}

The safety systems consist of the following:

(1) Plant Protection System

(2) Containment Isolation System

Plant Protection System

The plant protection system consists of two reactor shutdown systems which are as follows: 
(1) Primary Shutdown System

(2) Secondary Shutdown System

The primary and secondary shutdown systems, developed by C-E, employ electromagnetic and pneumatic release mechanisms respectively and provide an independent and diverse means of reactor scram. The latch, holding the control assembly, is released upon receipt of a scram signal. The control assembly release and drop times (less than 2 seconds) are comparable to those of CRBRP.

An alternate secondary shutdown system, incorporating a self actuated feature, has been developed by $C-E$ under contract to EPRI. The self actuated shutdown system relies on sodium flow to both hold out (at normal flow rates) and release (at low flow rates) the control assembly. In addition the control assembly is automatically released upon occurrence of a fast decrease in flow rates which exceeds the normal rate of change of flow rates. This is due to activation of a rate-of-change-of-pressure device which acts on the principle of release of stored potential energy upon a sharp drop in flow rate to release the control assembly for reactor shutdown. The device is an integral part of the control assembly and is wholly contained within the reactor assembly so that it is not influenced by occurrences outside the reactor boundary. The self activated shutdown systern, therefore, protects the reactor against events such as pump trip without scram and serves as a backup to the primary shutdown system. This alternate design is also actuated by the Plant Protection System.

Each system has detectors capable of responding to al1 anticipated faults, and a reactivity control system capable of reactor shutdown with one stuck control rod. Each system is redundant within itself and capable of meeting the single failure criterion in conformance with NRC guidelines. 
The Containment Isolation System consists of redundant instrumentation which senses the need for closure of certain valves in 7 ines directly connected to the containment atmosphere. The system is designed so that the isolation valves are automatically closed within a specified time to secure the containment and limit release of radioactivity.

\subsubsection{Control Systems}

The instrumentation and control equipment used for control of the reactor and heat transfer system and the auxiliary and process systems which make up the INSS are divided into the following systems:
1) Neutron Flux Monitoring
2) Process Instruments
3) Plant Control
4) Process Control

Neutron Flux Monitoring

This system measures the reactor neutron flux, which is proportional to the thermal power generated in the core. During power operation, the system provides a neutron flux control signal to the Plant Control System which sets reactor power to the setpoint power by moving control rods. If emergency or unsafe conditions arise, the system will generate signals which will be used by the Plant Protection System to shut down the reactor and stop the main heat transfer system sodium pumps.

The Neutron Flux Monitoring System is composed of two separate and independent systems: 
1) The In-Vessel Flux Monitoring System, which is used for refueling subcriticality determination.

2) The Ex-Vessel Flux Monitoring System, which is used during reactor operation.

The In-Vessel Flux Monitoring System, used for determination of the shutdown reactivity during refueling operations, consists of neutron detectors, preamplifiers, power supplies, and a subcriticality monitoring unit. The output of the system, in the event that loading errors lead to an approach to criticality, is an interlock signal to the IVTM to prevent the further addition of fuel.

The Ex-Vessel Flux Monitoring System measures the reactor neutron flux over the full range from the initial source level to $200 \%$ power, and provides signals to the Plant Control System, the Plant Protection System, and the Plant Data System. The system consists of three types of instrument channels wide range, linear protective, and linear power channels - each consisting of three redundant channels.

Process Instruments

This category includes all process instruments (sensors and signal conditioning equipment) that supply input signals to the Reactor Power Control System and the control systems for the various auxiliary and process systems, with the exception of the Neutron Flux Monitoring System described earlier. The more significant of these are as follows.

Temperature measurements throughout the NSSS are made with stainless stee sheathed, magnesium-oxide-insulated, Chromel-Alumel thermocouples. The temperature of fluids or gases in piping or heat transfer components is measured with thermocouples welded to the outside of the piping or vessel or, if a short time constant is important, located in a thermal well. 
The basic instrument for the measurement of sodium flow in all sodium systems is the permanent magnet electromagnetic (EM) flowmeter. This type of flowmeter can be used on all pipe sizes from $T$ in. up to that required for the main heat transfer loops. A multi-electrode configuration is used to obtain improved linearity of the flow vs. output voltage characteristic, and to provide for signal isolation when used in the protection system.

NaK-filled volumetric pressure transducers will be used for pressure measurements in sodium systems. These transducers consist of a diaphragm or bellows which is in contact with the sodium and acts as a seal, an interconnecting capillary line between the seal and a pressure measurement elastic member, and a transducer which converts displacement to an electrical or pneumatic signal. The capillary is filled with NaK, a sodium-potassium alloy. The pressure-sensing portion of the device is of a11-welded construction and is welded into the pipe or vessel where the pressure measurement is to be made. The seal member senses the sodium pressure changes through the diaphragm (or bellows) seal and transmits them via the incompressible fluid NaK through the capillary to a transducer located remotely in a less severe environment.

Two basic types of sodium level measurement devices are used. The first type provides a simple on-off type signal when a given level is reached. The second provides a continuous measurement of level over a specified range. Both types employ inductive coils which are installed in clasedend, stainless-steel thimbles extending into the sodium. They operate on the principle that a coil energized by an alternating current will induce a current in any closed conducting path surrounding the coil that depends on the impedance (sodium or air) of the surrounding material.

Sensors provide control rod position information for the control rod drives. In the reference design, the shim-safety rod drives have two methods of rod position indication. Linear variable differential transformers (LVDT) are used as an absolute measure of rod drive position. A more precise differential position measurement is obtained by counting the number of pulses to the roller nut drive motors. 
Conventional process instruments are used for pressure and flow measurement of argon and nitrogen gas, water and steam, etc.

\section{Plant Control}

The control system for the once through steam generator system consists of reactor and heat transport feedback control systems, and a master control (MC). The master control provides the setpoints for the feedback control systems and can be used for "fed forward" or anticipatory control for reactor operation at $40 \%$ to $100 \%$ range of power leve1. Below $40 \%$ power level, the plant systems are in the manual control mode of operation.

When a load increase is demanded, simultaneous increases are demanded in feedwater flow, intermediate loop sodium flows, and primary loop sodium flows. The total primary loop flow increases, resulting in a demand for inceased neutron flux, and is met by pulling reactor control rods. Hence, with an increase in load, there is a rapid increase in system flows and in reactor flux. Thereafter, a number of trim signals are applied to the controllers to maintain steam pressure and sodium temperatures at the values determined by the part-load schedule. These trim control actions include adjustment of feedwater pressure, reactor outlet temperature, and the cold and hot leg temperature of the intermediate sodium loops.

The power demand plus the main steam header pressure control error signal are inputs to the master control unit and form the plant load demand. The master control unit converts the load demand to properly scaled setpoints for the individual control systems according to the part load schedule for that particular controlled variable.

It is possible for the plant operator to set the load demand manually. If steam pressure is then placed under control of the initial pressure regulator on the turbine, the plant operates in a "load-forcing" mode where the turbine accepts the power produced by the reactor. 
The final control elements are the shim-safety control rods which are positioned by a controller in response to feedback from flux sensors. This subassembly is called the flux controller.

The main index for the flux controller is the product of measured total sodium flow through the reactor and calculated reactor differential temperature set by the master control unit and the measured reactor inlet temperature. During normal operation, differential temperature is nearly constant, but it represents a scaling factor on measured flow.

The flux controller maintains, within the allowable deadband, reactor power at the demand value. The demand flux is primarily the steady-state power established by total primary sodium flow. A trim on outlet temperature is added to the demand for changing conditions.

The reactor temperature control system provides the trim signal to the flux controller. This signal maintains the reactor outlet temperature within its prescribed limits. The fuel assembly outlet temperature is fed back to the temperature controller. The setpoint for the controller is a floating proportional signal computed from the measured reactor outlet temperature and the corresponding setpoint signal provided by the master control unit.

The intermediate flow control is achieved with a cascade control system. The measured flow signal is compared by a flow controller to the setpoint value set by the master control unit. The output of the flow controller provides the setpoint for the cascade pump speed controller.

The primary flow control system is also a cascade control system similar to the intermediate system. However, an intermediate hot leg temperature trim control is combined with the flow setpoint signal set by the master control unit. The temperature trim signal acts to maintain the intermediate hot leg temperature and thus, steam temperature is at prescribed value and automatically compensates for heat transfer performance difference. 
The feedwater flow controller modulates the throttle valves in the feedwater line to maintain the flow at the value set by the master control unit. The intermediate cold leg temperature is maintained within prescribed limits by a trim signal derived from the measured value and master control unit setpoint, which is combined with the feedwater flow setpoint.

The feedwater pressure control system maintains feedwater pressure required to achieve a satisfactory differential pressure across the valves used for final control of feedwater flow.

Process Control Systems

Each of the following process and auxiliary systems has a separate instrumentation and control system as an integral part of this system:

1) Sodium Supply and Purification System

2) Stored Fuel Cooling System

3) Steam Generator Rupture Relief System

4) Argon Supply System

5) Nitrogen Supply System

6) Steam Generator Startup and Dump System

7) Radioactive Vent and Argon Purification System

8) Liquid and Solid Waste System 
2.3.8.4 NSSS Process Monitoring Instrumentation Systems

The instrumentation systems used to monitor the performance of the systems and components in the NSSS portion of the plant are grouped into the following systems:

1) In-Core Fuel and Core Structure Monitoring

2) Equipment Operating Surveillance

3) Coolant Composition Monitoring

4) Failed Element Detection and Location (FEDAL)

5) Radiation Monitoring System

In-Core Fuel and Core Structure Monitoring System

The In-Core Fuel and Core Structure Monitoring System provides the sensors and signal conditioners required to monitor the thermal, hydraulic, and structural performance of the reactor core complex. This system provides inputs to the Reactor Power Control System, the Plant Protection System and the Plant Data System.

Equipment Operating Surveillance System

The Equipment Operating Surveillance System provides the sensors, signal conditioning and, in some cases, the display and recording equipment used for: detection of anomalous performance, incipient failure detection, malfunction diagnosis, and verification of design parameters. These instruments are not required for normal plant operation. The majority of information developed by these instruments is recorded and displayed for use by the operator via the Plant Data System. 
Coolant Composition Monitoring System

The Coolant Composition Monitoring System provides the instruments and equipment used to measure the level of impurities in the sodium of the various heat transfer and process systems. Readout of these instruments is by locally mounted indicators and recorders and via the Plant Data System.

Failed Element Detection and Location

The FEDAL System is intended to provide monitoring instrumentation necessary to detect and locate failed or leaking fuel assemblies.

Radiation Monitoring System

The Radiation Monitoring System provides the instrumentation, control and indication circuits and devices required to detect, indicate and record the radiation levels in the various plant areas, process systems, and gaseous and liquid effluents. The Radiation Monitoring System will provide instrumentation to initiate containment isolation, to control safe refueling, and to monitor personnel. In addition, the system will provide indication and alarms to advise personnel of radiation levels throughout the plant, and portable radiation detection equipment for monitoring special activities such as refueling, maintenance activities and radiation surveys of the plant areas. 


\section{SECTION 3}

\section{COST ESTIMATE}

\section{$3.1 \quad$ INTRODUCTION}

This section contains the details of the total direct capital costs for the Nuclear Steam Supply System of the LMFBR plant described in Section 2. The criteria used to develop the cost estimates are specified in Section 1 and 2 . The cost estimates reflect the reference plant design at the "Middletown" hypothetical site.

The total direct capital cost for the NSSS is $\$ 267,574,000$ or $\$ 192 /$ KWe based on January 1978 prices. This cost is the factory shop-door se11 price and does not include owner's contingency, interest, escalation and installation costs.

The costs are organized in accordance with the expanded AEC Code of Accounts (USAEC Report NUS-531). Therefore, it corresponds in structure to the plant design description (Section 2) and the equipment list (Section 6).

\section{$3.2 \quad$ COST BASIS}

The cost bases for the major components and systems are presented here.

Reactor Vessel and Reactor Vessel Closure Head

The reactor vessel and reactor vessel closure head designs were analyzed from a cost point of view assuming the following conditions:

- The estimates include only hardware shown on the referenced figures (Section 2).

- The components are the fifth of a kind to be fabricated in C-E's shops; thus, the necessary specialized fixtures, shop handling equipment, and shop procedures are already in existence. 
- All basic engineering has been previously performed and only certain specalized customer-requested changes must be addressed.

- The estimates are based on shop-door costs of the completed components and do not include shipping fixtures or other costs associated with component transportation to the site, nor do the estimates include fees for installation or overseeing the installation of the components.

Primary Pumps

Rough estimates for pump costs and drives were obtained from the Byron Jackson Pump Division of the Borg Warner Company. These estimates are based on 1978 dollars and are subjects to escalation. These estimates are based on the following assumptions:

(1) Pumps are fifth-of-a-kind.

(2) Order of four plants per year is assumed.

(3) The estimates are for factory shop-door costs including design engineering and fabrication.

(4) Shipping and installation costs are not included.

(5) Pump supports, insulation and trace heating are not included.

\section{Intermediate Heat Exhangers}

The intermediate heat exchanger design was analyzed from a cost point of view assuming the following conditions:

- The estimate includes only that hardware shown in the referenced figure (Section 2). 
- The components are the fifth of a kind to be fabricated in C-E's shops; thus, the necessary specalized fixtures, shop handling equipment, and shop procedures are already in existence.

- All basic engineering has been previously performed and only certain specalized customer-requested changes must be addressed.

- The estimates are based on shop-door costs of the completed components and do not include shipping fixtures or other costs associated with component transportation to the site, nor do the estimates include fees for installation or overseeing the installation of the components.

Piping

Piping lengths for large diameter piping were estimated by measurement of centerline distances between fittings from the layout drawings (Section 5). The piping lengths for sma11 diameter piping were estimated by applying a length factor to the centerline distance between components. The length factors used for the sodium and gas piping are 2.0 and 1.5 respectively to allow for expansion loops and routing. The costs for the piping was derived from the CRBRP piping costs by adjustments for escalation and classification.

\section{Steam Generators}

The steam generator design was analyzed from a cost point of view assuming the following conditions:

- The estimate includes only that hardware shown in the reference figure (Section 2).

- The components are the fifth of a kind to be fabricated in C-E's shops; thus, the necessary specialized fixtures, shop handling equipment, and shop procedure are already in existence. 
- All basic engineering has been previously performed and onty certain specialized customer-requested changes must be addressed.

- The estimates are based on shop-door costs of the completed components and do not include shipping fixtures or other costs associated with component transportation to the site, nor do the estimates include fees for installation or overseeing the installation of the components.

\section{Expansion Tank}

The Secondary Sodium Expansion Tank design was analyzed from a cost point of view assuming the following conditions:

- The estimate includes only that hardware shown in the above referenced figure (Section 2).

- The components are the fifth of a kind to be fabricated in C-E's shops; thus, the necessary specialized fixtures, shop handing equipment, and shop procedures are already in existence.

- All basic engineering has been previously performed and only certain specialized customer-requested changes must be addressed.

- The estimates are based on shop-door costs of the completed components and do not include shipping fixtures or other costs associated with component transportation to the site, nor do the estimates include fees for installation or overseeing the installation of the components.

Fue1 Handling Components

In-Vessel Handling and Auxiliary Handling Machines

These machines are similar in function and design to those for the CRBRP. The cost extimates for these machines were, therefore, based on the CRBRP cost estimates with adjustments for a fifth of a kind plant. 


\section{Ex-Vessel Handling Machine}

This machine is similar in function to the EBR II unloading machine and the C-E System 80 refueling machine. The cost estimate for this machine was, therefore, developed using the cost data base of the C-E System 80 refueling machine. Some adjustments to the price were made for complexity and additional hardware required for cooling and shielding of the Target Plant machine.

\section{Ex-Vesse 1 Storage Tank}

The EVST was assumed to be similar in design and layout as that for CRBRP. The Ex-Vessel Storage Tank design was analyzed from a cost point of view assuming the following conditions:

- The estimate includes only that hardware shown on the referenced figure (Section 2).

- The components are the fifth-of-a-kind to be fabricated in C-E'S shops; thus, the necessary specialized fixtures, shop handling equipment, and shop procedures are already in existence.

- All basic engineering has been previously performed and only certain specialized customer requested changes must be addressed.

- The estimates are based on shop door costs of the completed components and do not include shipping fixtures or other costs associated with component transportation to the site nor do the estimates include fees for installation or overseeing the installation of the components.

Other components for the Fuel Handling System such as floor valves, cranes, conveyors, etc., are fairly common industrial components. The prices for these components were obtained from the C-E System 80 data base. 
Every proposed LMFBR reactor design includes a unique refueling scheme and refueling machines. Because of non-typicality a large uncertainty remains in the cost estimates of these machines inspite of exercise of experienced engineering judgement. It is estimated that this uncertainty could result in cost to estimate ratio between 0.5 and 2.0 .

Auxiliary System

A11 component costs were estimated on a basis similar to current LWR practice, especially those items similar in kind to current LWR components. Cost estimates were provided for a fifth-of-a-kind plant. Standard sodium components such as electromagnetic pumps and filters were priced by contacting vendors using Target Plant design requirements. Vaporizers, distillation units, etc., were treated as heat exchangers and priced according to similar LWR units. All tanks were priced as $3045 S$ and were treated according to function as similar LWR tanks. Other sodium related equipment was priced according to design description and function using LWR cost estimators.

Sodium valve requirements were extrapolated from existing LMFBR designs and scaled to the Target Plant specifications with one generic valve type assumed to represent all valves. Classification of valves as remote and manual actuation was also estimated. Sodium piping lengths for the auxiliary systems were produced by considering the straight line lengths from one component to another and using a factor of 2 to account for thermal expansion and pipe routing additions. Inert gas valve requirements were based on Target Plant specifications for systems currently designed such as the RAPS, and were approximated for other systems currently under design such as the CAPS. A single valve type was assumed to allow for the estimation of inert gas valve costs. Piping lengths were based on a straight line distance between distribution manifolds and the various components. A factor of 1.5 was applied to account for routing and thermal expansion effects.

Instrumentation and Control

The prices for standard I\&C were obtained from the comparable C-E System 80 cost data base. The costs of the specialty components were estimated based on information obtained from värious vendors. 
A summary of the cost estimates for the Nuclear Steam Supply System is given in Table 3.1 . 
TABLE 3.1

\section{COST ESTIMATE SUMMARY}

1390 MWe LIQUID METAL FAST BREEDER REACTOR PLANT

\begin{tabular}{|c|c|c|c|}
\hline & & QUANTITY & $\begin{array}{l}\text { COST (DOLLARS) } \\
\text { (THOUSANDS) }\end{array}$ \\
\hline $220 A .21$ & Reactor Equipment & & \\
\hline 220A. 211 & Reactor Vessels & & \\
\hline $220 A .2111$ & Reactor Vessel Shell & 1 & 14,820 \\
\hline $220 A .2112$ & Vessel Head + Accessories & & \\
\hline 220A. 21121 & Vessel Closure Head & 1 & 11,102 \\
\hline $220 A .21122$ & Heating + Cooling Equipment & Not Included & \\
\hline $220 A .21123$ & Gears + Misc. Equipment & 1 set & 22 \\
\hline $220 A .21124$ & Plug Drive + Control & 1 set & 600 \\
\hline $220 A .21125$ & Rotary Seals + Maintenance Tools & 1 set & 30 \\
\hline $220 A .21126$ & Bearings & 1 set & 156 \\
\hline $220 A .21127$ & Shielding & 187,000 lbs. & 449 \\
\hline $220 A .21128$ & Insulation & \multirow{2}{*}{\multicolumn{2}{|c|}{ Included in 220A.21121 }} \\
\hline $220 A .2113$ & Cavity Filler System & & \\
\hline $220 A .21131$ & Filler Blocks & 860,000 lbs. & 3,612 \\
\hline \multirow[t]{2}{*}{$220 A .21132$} & $\begin{array}{l}\text { Filler Block Handling + Support } \\
\text { Mechanisms }\end{array}$ & 1 set & 1,090 \\
\hline & 220A.211 Reactor Vessels Tota 1 & & 37,881 \\
\hline
\end{tabular}


TABLE 3.1 (Continued)

QUANTITY

COST (DOLLARS)

(THOUSANDS)

\begin{tabular}{|c|c|c|c|}
\hline \multirow{2}{*}{$\begin{array}{l}220 A .212 \\
220 A .2121\end{array}$} & \multicolumn{3}{|l|}{ Reactor Vessel Internals } \\
\hline & Lower Internals & & \\
\hline \multirow{5}{*}{$220 A .2122$} & Core Support Structure & 1 & 6,023 \\
\hline & Upper Internals & & \\
\hline & Suppressor Plate Assembly & 1 & 818 \\
\hline & Upper Shroud & 1 set & 876 \\
\hline & CRITA Support/Guide Tubes & 61 & 1,560 \\
\hline $220 A .2123$ & Core Restraint/Core Barrel & 1 set & 1,326 \\
\hline $220 A .2124$ & Baffles/Seals & 1 set & 541 \\
\hline $220 A .2125$ & As semblies & & \\
\hline $220 A .21251$ & Core Assemblies & Not Included & \\
\hline 220A. 21252 & Blanket Assemblies & Not Included & \\
\hline $220 A .21252$ & Reflector + Shield & Not Included & \\
\hline $220 A .21254$ & Fuel Transfer Assemblies & Not Included & \\
\hline $220 A .21255$ & Instrumentation Assemblies & 61 & 1,638 \\
\hline \multirow[t]{2}{*}{$220 A .25256$} & Piping Assembly (Check Valves) & 4 & 837 \\
\hline & 220A.212 Reactor Vessel Internals & Total & 13,619 \\
\hline $220 A .213$ & Control Rod System & & \\
\hline $220 A .2131$ & Control Rods & Not Included & \\
\hline $220 A .2132$ & Control Rod Drives & 30 & 2,730 \\
\hline
\end{tabular}


TABLE 3.1 (Continued)

QUANTITY

COST (DOLLARS)

(THOUSANDS)

220A.22 Heat Transport Systems

220A.221 Primary Heat Transport System

220A. 2211

Pumps

4

13,360

Motors

4

2,000

Control (Variable Speed Drives)

4

2,800

Pony Motors

4

200

220A. 2212

Primary Piping System

220A. 22121

Piping

Large Diameter Piping

$2100^{\prime}$

13,046

Intermediate Diameter Piping

$628^{\prime}$

520

Small Diameter Piping

$736^{\prime}$

202

Supports (Materials only)

2,840

220A.22122 Valves

Large Vaives

8

1,584

Small Valves

36

1,440

220A. 2213

Intermediate Heat Exchanger

4

21,450

220A. 2214

Guard Vesse1s

Not Applicable

220A. 2215

Heating System

Included in 220A.262

220A. 2216

Insulation

Not Included

220A. 221

Primary Heat Transport System Total

$\underline{59,442}$ 
TABLE 3.1 (Continued)

QUANTITY

COST (DOLLARS)

(THOUSANDS)

220A.222 Intermediate Heat Transport System

220A.2221 Pump + Motor + Control

Pumps

4

10,200

Motors

4

1,800

Control (Variable Speed Drive)

4

2,800

Pony Motors

200

220A.22221 Int. Piping System

Large Diameter Piping

$3120^{\prime}$

2,821

Sma11 Diameter Piping

$2088^{\prime}$

90

Supports (Material)

1,512

220A.22222 Valves

Large Valves

8

1,440

Small Valves

56

1,680

220A.2224 Tanks

Expansion Tanks

4

780

220A. 2225

Heating System

Included in 220A.262

220 A. 2226

Insulation

Not Included

220A.222 Intermediate Heat Transport System Total 


\section{TABLE 3.1 (Continued)}

QUANTITY

COST (DOLLARS)

(THOUSANDS)

220A.223 Steam Generation System

220A.2232 Steam Generators

220A.22321 Evaporators

$8 \quad 41,990$

220A.22322 Superheaters Included above

220A.22323 Steam Drums Not Applicable

220A.2233 Na/ $/ \mathrm{H}_{2} \mathrm{O}$ Reaction Protection System

220A.22331 Centrifuges, Tanks

$12 \quad 5,544$

220A.22332 Piping + Valves

$\begin{array}{lll}\text { Piping } & 764^{\prime} & 361\end{array}$

$\begin{array}{lll}\text { Valves } & 50 & 604\end{array}$

220A.2236 Insulation Not Included

220A.223 Steam Generation System Total

220A.22 Heat Transport Systems 
TABLE 3.1 (Continued)

QUANTITY

COST (DOLLARS)

(THOUSANDS)

$\begin{array}{llr}220 A .23 & \text { Safeguards Systems } & \\ 220 A .231 & \text { Backup Heat Removal System } & 8 \\ 220 A .2311 & \text { Pumps, Fans + Motors } & 6 \\ \text { 220A.2311 } & \text { Heat Exchange Equipment } & 2 \\ 220 A .2313 & \text { Tanks } & 101 \\ \text { 220A.2314 } & \text { Piping + Valves } & 18 \\ & \text { Piping } & \\ & \text { Valves } & \\ & & \\ & 220 A .231 \text { Backup Heat Removal System } \\ & & \end{array}$

$\underline{9,431}$ 
TABLE 3.1 (Continued)

Fuel Handling and Storage

220A. 251

Rec., Storage and Shipping

New Fuel Handling Crane

1 set

66

New Fuel Storage Racks

1 set

374

220A. 252

Ex-Vessel Storage Tank

1

17,485

220A. 253

Ex-Vessel Handling Mechanisms

EVHM Trolley + Rails

1 set

19

EVHM

1

2,672

Spent Fuel Cask Cart

1

180

220A. 254

Transfer Mechanisms

Transfer Arm + Motor

1 set

42

Refueling Elevator and Motor

1 set

42

Transfer Pots

300

2,422

220A. 255

Invessel Handling Mechanisms

1

1,100

220A. 256

Fuel Handling Cells

New Fuel Conveyor + Tubes

1 set

60

Ce11 Equipment

1 set

48

220A. 257

Piping + Valves

Piping

$2440^{\prime}$

886

Valves

14

241

Supports (Materials Only) 
TABLE 3.1 (Continued)

Misc. Equipment

Auxiliary Handling Machine

Tanks

Pumps

$H X$

Cold Traps

220A. 25

Fuel Handling and Storage Total
QUANTITY

COST (DOLLARS)

(THOUSANDS)

$1 \quad 1,600$

2

11

607

528

768

29,902 
TABLE 3.1 (Continued)

QUUANTITY

COST (DOLLARS)

(THOUSANDS)

$220 A .26$

Other Equipment

220A.261

Inert Gas Receiv. + Process

220A.2611

Pumps, Compressors + Drives

5

420

220A.2612

Gas Supply/Storage Tanks

27

$\cdot 2,083$

220A.2613

Gas Purification Units

70

2,292

$220 A .2615$

Piping, Valves + Fittings

3,480

220A.261 Inert Gas Receiv.+ Process Total

$\underline{8,275}$

$220 A .262$

Special Heating Systems

220A.2621

Trace Heater System

6,390

220A.262 Special Heating Systems Total

$\underline{6,390}$

$220 A .264$

Sodium Storage, Relief, Makeup

10,412

220A.265

Sodium Purification System

4,301

$220 A .266$

NA Leak Detection System

Included in $220 \mathrm{~A} .27$

220A.267

Auxiliaries Cooling Equipment

Not Included

220A. 268

Maintenance Equipment

Not Included

220A.26 Other Equipment Total

$\underline{29,378}$

$220 A .27$

Ins trumentation + Controls

19,369

220A.2 Distributed NSSS Cost

267,574 


\section{SECTION 4}

\section{COMPARISON AND DISCUSSION}

In order to identify the major cost differentials between an LMFBR and an LWR, the C-E System 80 was selected for comparison with the Target Plant. The two plants have an identical thermal rating (3800 Mwt) and utilized a similar cost data base for the development of capital costs. A comparison of cost related parameters (commodities) of the major systems and components, therefore, should bring out the reasons for cost differentials between the two plants. This comparison is presented in this section.

\section{Overall Plant}

A comparative layout of the two plants is shown in Figure 4.1. The Target Plant layout indicates a larger containment building due to a larger reactor vessel, the expansion loops of the PHTS and a need for housing a large number of components associated with fuel handling and auxiliary systems as compared to that of the C-E System 80 . Furthermore, additional steam generator buildings are required for the Target Plant to house the steam generator system; no such buildings are required for the C-E System 80 .

Reactor Vessel and Reactor Vessel Closure Head

In comparing the LMFBR Vesse 1 and Closure Head with the C-E System 80 Reactor Vessel and Closure Head, few similarities are found. The commodities 1ists given in Tables 4.1 and 4.2 , provide a detailed comparison of pertinent features and constituent parts of the two assembies. Certain of the more cost-influential of these comparisons are discussed in the following paragraphs.

The LMFBR and PWR Reactor Vessels, as illustrated in Figure 4.2, are both designed and fabricated to the requirements of Section III Class 1 of the ASME Boiler and Pressure Vessel Code; however, the LMFBR Vessel design must 
also include the more costly considerations of Code Case 1592 for high temperature applications.

The LMFBR Vessel is physically larger than the PWR Vessel (to facilitate the breeder core); however, the design and operational pressure are much lower, thus the vessel wall is much thinner for the LMFBR than for the PWR. (Wa11 thicknesses for the LMFBR are in the 2.5 to 3.5 inch range as opposed to the 9.0 to 12.0 inch range for the PWR.) It is interesting to note that the larger size/thinner wall configuration of the LMFBR Reactor Vessel results in a component weight which is essentially the same as that of the smaller size/thicker wall PWR. In addition, the LMFBR Vessel has approximately 3.5 times as many linear feet of weld as does the PWR Vessel, but the total poundage of weld metal is approximately the same. This, again, is due to the thinner wall of the LMFBR Vessel. The entire inner surface of the PWR Vessel is clad with stainless steel while the entire LMFBR Vessel is fabricated with stainiess steel. Thus, from the materials and construction points of view, it can be concluded that the LMFBR Vessel is fabricated from an equal weight of more expensive material utilizing an equal amount of weld metal with more linear feet of weld.

The LMFBR Vessel includes a thermal liner which complicates design and fabrication particularly in the areas where nozzle liners must penetrate the thermal liner. Since the PWR Vessel has no such liner, this feature must be considered as a major cost influencing item.

The large number of nozzles (28 total) found within the LMFBR Vessel somewhat balance out the smaller number of nozzles found within the PWR Vessel ( 6 total) when the PWR's 61 control rod penetrations are considered.

There is really no meaningful way to compare the LMFBR Closure Head to the PWR Closure Head. One is complicated in nature containing precision moving parts, biological and thermal shielding, etc. while the other is simply a flanged hemispherical weldment. The weight of the composite LMFBR Head is approximately six times that of the PWR Closure Head. While the simple 


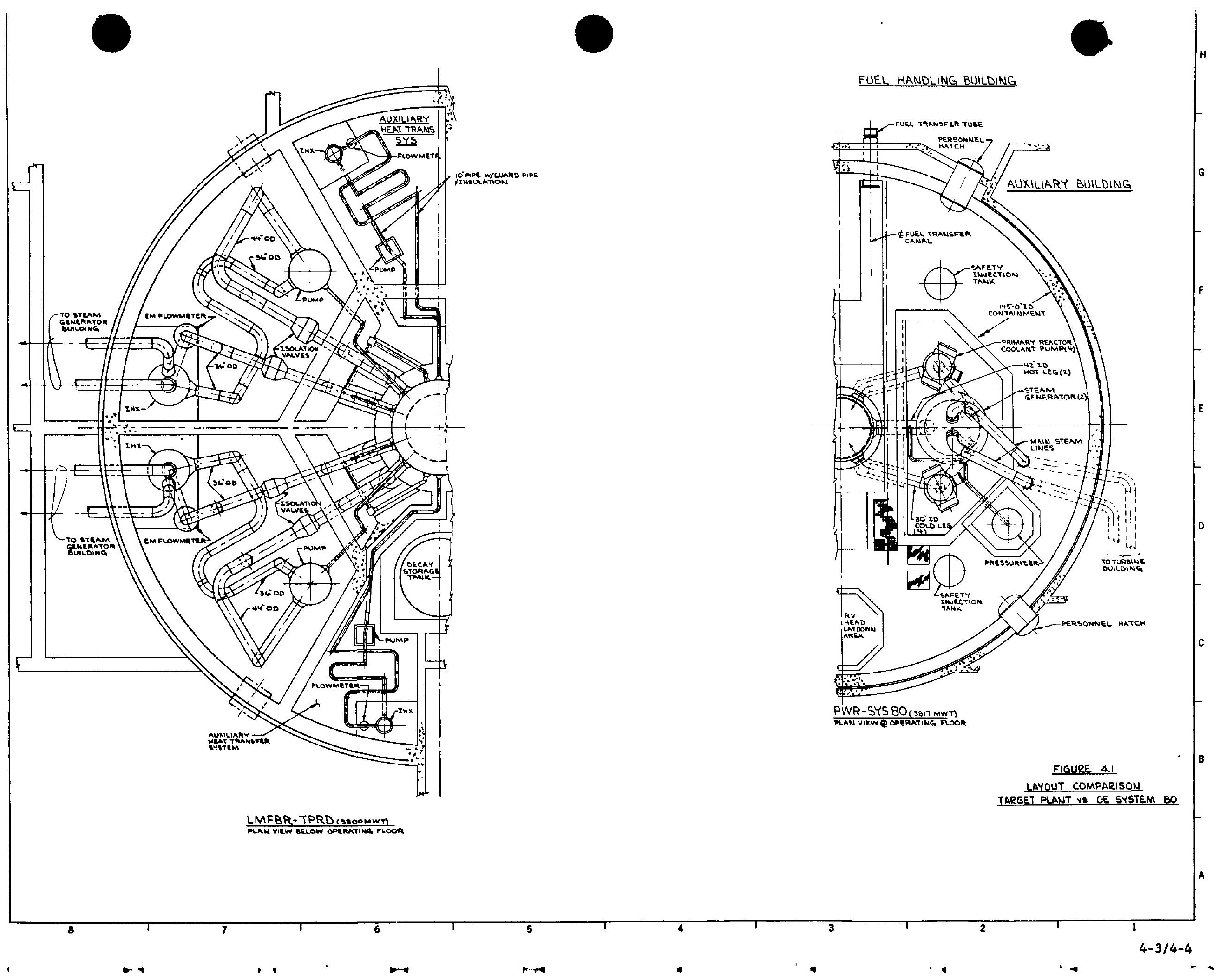


TABLE 4.1

COMPARISON OF REACTOR VESSELS

DESCRIPTION

Number of Components per Plant

Design and Operating Conditions

Design Pressure/Temp. (Inlet Plenum)

Design Pressure/Temp. (Outlet Plenum)

Flow Rate

Fluid

Inlet Temperature/Outlet Temperature

Heat Load

Safety Class

Physical Size and Weight

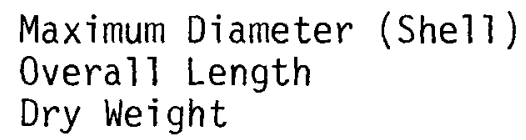

Materials

She 11

Flange

Shell to Flange Transition

Therma? Liner

\section{COMPARISON OF COMPONENT SHELLS}

Shell Plate Thicknesses

$$
\begin{aligned}
& \text { Upper Cylindrical Region } \\
& \text { Lower Cylindrical Region } \\
& \text { Lower Head }
\end{aligned}
$$

Internal Cladding

Location

Material/Thickness

Nozzles

$$
\begin{aligned}
& \text { Inlet - Qty./I.D. } \\
& \text { Outlet - Qty./I.D. } \\
& \text { Other - Qty. }
\end{aligned}
$$

PWR

$C-E$

SYSTEM 80

1

$2500 \mathrm{Psia} / 650^{\circ} \mathrm{F}$

2500 Psia $/ 650^{\circ} \mathrm{F}$

$164 \times 10^{6} \mathrm{lbm} / \mathrm{hr}$

$\mathrm{H}_{2} \mathrm{O}$

$565.0^{\circ} \mathrm{F} / 621.2^{\circ} \mathrm{F}$

3800 Mwt

Section III Class I

$17^{\prime}-7.65^{\prime \prime}$

$39^{\prime}-2.66^{\prime \prime}$

996,730 lbs.

SA-533, Gr. B, C . I SA-508, Class 3

None

None

$11.19^{\prime \prime}$

$9.06^{\prime \prime}$

$6.50^{\prime \prime}$

Entire Inner Surface Stainless Steel

$3.50^{\prime \prime}$

$2.50^{\prime \prime}$

$2.50^{\prime \prime}$

None

None

$4 / 35.00^{\prime \prime}$

$4 / 43.00^{\prime \prime}$
$4 / 30.00^{\prime \prime}$

2/42.00"

None
LMFBR

$165 \mathrm{Psia} / 675^{\circ} \mathrm{F}$

$40 \mathrm{Psia} / 975^{\circ} \mathrm{F}$

$\mathrm{Na}$

$650^{\circ} \mathrm{F} / 950^{\circ} \mathrm{F}$

$3800 \mathrm{Mwt}$

$27^{\prime}-5.00^{\prime \prime}$

(1.79"

924,900 lbs.

SA-240, Type 304

SB-168

SA-240, Type 304
20 
TABLE 4.1 (Continued)

\begin{tabular}{lc} 
PWR \\
COMPARISON OF COMPONENT SHELLS (Cont) \\
C-E \\
SYSTEM 80 \\
\hline
\end{tabular}

Penetrations in Lower Head - Qty.

Lineal Feet of Welds

Upper Flange

Inside Diameter

Outside Diameter

Height

THERMAL LINER COMPARISON

Outside Diameter

Thickness

Length

SUPPORT SYSTEM COMPARISON

Flange

Outside Diameter

Height

Skirt

Thickness

Height

COMPARISON OF CONSTITUENT WEIGHTS

Weight of Shell

Shell Plate

Nozzles

Weld Metal

Upper Flange

Total Weight of Shell
67

320 Ft.

$175.00^{\prime \prime}$

$215.63^{\prime \prime}$

$28.82^{\prime \prime}$

None

None

None

None*

None*

$404.00 "$

$12.00 "$

None*

None*

$6.00^{\prime \prime}$

$19.15^{\prime \prime}$
LMFBR

TARGET PLANT

None

$1085 \mathrm{Ft}$.

$324.00^{\prime \prime}$

$361.00^{\prime \prime}$

$38.00^{\prime \prime}$

$26^{\prime}-10.0^{\prime \prime}$

$1.50^{\prime \prime}$

$10^{\prime}-7.00^{\prime \prime}$
525,600 Lbs.

17,300 Lbs.

18,700 Lbs.

153,900 Lbs.

715,500 Lbs.

*Weight of Support System (Pads on Nozzles) included with Inlet Nozzles. 


\section{TABLE 4.1 (Continued)}

\section{PWR \\ $C-E$}

SYSTEM 80

\section{(Cont)}

Weight of Support Skirt and Flange

Flange Weight

Skirt Weight

Total Support Skirt and Flange Weight

Weight of Thermal Liner

Total Weight of Thermal Liner

Weight of Miscellaneous Items

Total Weight of Miscellaneous Items

LMFBR

TARGET PLANT

68,300 Lbs.

None

69,300 Lbs.

120,430 Lbs.

30,300 Lbs. 41,500 Lbs. 109,800 Lbs.

*

$\star$

*Weight of Support System (Pads on Nozzles) Included with Inlet Nozzles. 
TABLE 4.2

COMPARISON OF CLOSURE HEADS

\section{DESCRIPTION}

Number of Components per Loop

Component Type or Configuration

Design and Operation Conditions

Design Pressure/Temp. (Structure)

Design Pressure/Temp. (Insulation)

Safety Class

Physical Sizes and Weights

Flange Outside Diameter

Flange Inside Diameter

Flange Height

Head Radius (Inner)

Head Thickness

Large Rotating Plug Diameter

Intermediate Rotating Plug Diameter

Shell Rotating Plug Diameter

Thickness of Biological Shielding

Thickness of Thermal Shielding

Overall Height

Total Weight

Material

Flange

Head

Biological Shielding

Thermal Shielding

Seals

Quality

Type

Material

Number of Control Rod Penetrations

Number of Bearings, Drives, and Controls None
PWR

C-E

SYSTEM 80

1

Flanged Hemispherical

2,500 Psia $/ 650^{\circ} \mathrm{F}$

None/None

Section III, Class I

$17^{\prime}-11.63^{\prime \prime}$

$13^{\prime}-7.68^{\prime \prime}$

$28.22 "$

$88.19^{\prime \prime}$

$8.00^{\prime \prime}$

None

None

None

None

None

$96.91^{11}$

224,900 Lbs.

SA-508, Class 3

SA-533, Gr. B

None

None

1 Set of 2

Metal 0-Ring

Inconel 718

97

$28^{\prime}-0.00^{\prime \prime}$

$22^{\prime}-6.00^{\prime \prime}$

$24.00 "$

Flat

$24.00^{\prime \prime}$

$279.00^{\prime \prime}$

$228.50^{\prime \prime}$

$106.00 "$

$30.00^{\prime \prime}$

$12.00^{\prime \prime}$

$120.00^{\prime \prime}$

$1,380,000$ Lbs.

SA-508, Class 3

SA-508, Class 3

Graphite

SA-240, Type 304
3 Sets

Inflatable and Na Dip Silicon Rubber and $\mathrm{Na}$

61

3 


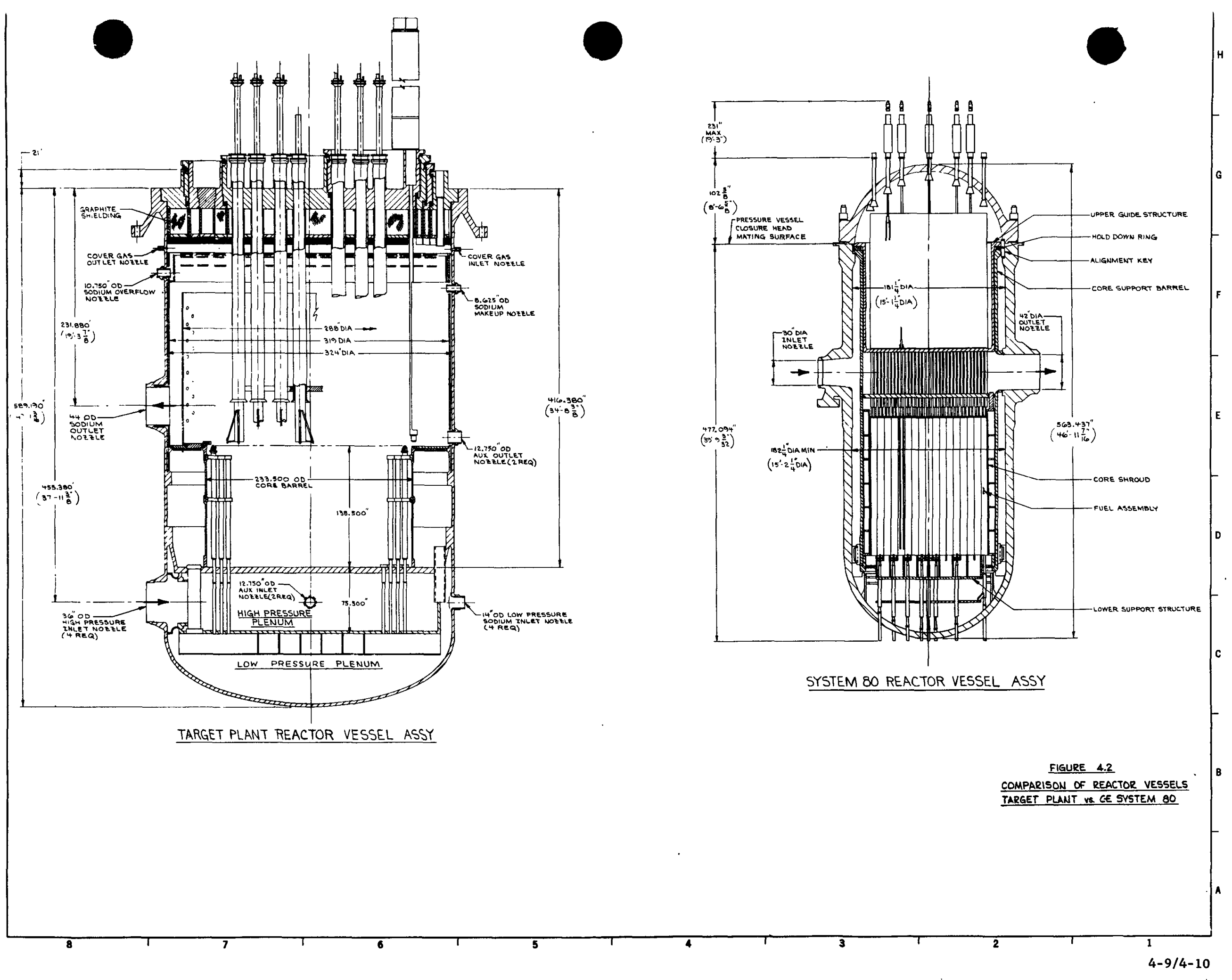


design of the PWR Closure Head offsets a portion of the cost of the LMFBR Head, the LMFBR Head can almost be viewed as a component unique to the LMFBR System.

Reactor Vessel Internals

Comparative parameters of the reactor vessel internals for the plant are shown in Table 4.3 .

The reactor vessel internals of the Target Plant incorporate a large number of baffles, shrouds and flow dividers due to the requirement for flow distribution in a high temperature system. Furthermore the incorporation of removable check valves and instrument trees impose complex design and fabrication requirements for the reactor vessel internals. The vessel internals for the C-E System 80, in comparison, are simple in design and fabrication because of the lower temperature of that system. The core support structure for the Target Plant is approximately two times larger and four times heavier because of the larger core and has an additional requirement of hydraulic holdown for the fuel assemblies as compared to that of the C-E System 80. Under-the-plug refueling for the Target Plant also imposes complex engineering requirements for the reactor vessel internals as compared to the open head refueling for the C-E System 80 . Overa 11, the reactor vessel internals weigh approximately $50 \%$ more and are more numerous and complex than those for the C-E System 80 .

Cavity Filler System

The reactor vessel for the Target Plant must be enclosed with a volume limiting system to limit the loss of sodium from the primary sodium system. In the Target Plant, this is achieved by means of a system of filler blocks rather than with a guard vessel. This system ensures continuity of core submergence in sodium and heat removal subsequent to a loss of coolant accident. It is a major cost item which has no parallel in the C-E System 80 . 
TABLE 4.3

\section{COMPARISON OF REACTOR VESSEL INTERNALS}

\section{DESCRIPTION}

Number of Components (sets)

Design Temperature $\left({ }^{\circ} \mathrm{F}\right)$

Fluid

Flow Rate (LBM/HR)

Material

Lower Internals

Core Barrel

Size

Weight (1bs)

Core Support Structure

Size

Weight (1bs)

Upper Internals

CRITA Tubes/Supports

Quantity

Size

Weight (1bs)

Shroud

Size

Weight (1bs)

Suppressor Plates

Quantity

Size

Weight (1bs)

Check Valves

Quantity

Type

Size

Weight (1bs)

Total Weight of Internals (1bs) 453,088

Total Feet of Weld
PWR

C-E SYSTEM 80

1

650

${ }^{\mathrm{H}} \mathrm{O} 4 \times 10^{6}$

304 SS

$150^{\prime \prime} \times 175^{\prime \prime} \times 7 / 8^{\prime \prime}$

39,222

$156^{\prime \prime} \times 30^{\prime \prime} \times 1.75^{\prime \prime}$

81,000
LMFBR

TARGET PLANT

1

$975 / 675$

$\mathrm{Na}$

$143.2 \times 10^{6}$

304 SS
None

$148^{\prime \prime} \times 30^{\prime \prime} \times 1.25^{\prime \prime}$

5,039

1

$124^{\prime \prime} \phi \times 1-3 / 4^{\prime \prime}$

3,677

None

$233^{\prime \prime} \times 138^{\prime \prime} \times 1^{11} t$ 78,444

$300^{\prime \prime} \times 75^{\prime \prime} \times 3^{\prime \prime}$

323,970
61

$15^{\prime \prime} \phi \times 17^{\prime} \times 1 / 2^{\prime} t$ 92,300

$300^{\prime \prime} \times 165^{\prime \prime} \times 7^{\prime \prime}$

38,260

3 $306^{\prime \prime} \phi \times 1 / 2 " t$ 33,890
4

Swing Disc

$36^{\prime \prime}$

41,840

644,930

67,435 
TABLE 4.3 (Continued)

PWR

C-E SYSTEM 80

LMFBR

TARGET PLANT

\section{CRITA}

Quantity

Type

Size

Control Rod Drives

Quantity

Type

Size

Control

Stroke
99

Magnetic Jack $4^{\prime \prime} \phi \times 28^{\prime}$

Electro Magnet 148"
61

Telescoping

$15^{\prime \prime} \phi \times 20^{\prime}$

Fixed Tubes

3"ф
30

Servo Drive

$12^{\prime \prime} \phi \times 30^{\prime}$

Pneumatic $48^{11}$ 
Heat Transport System Pumps

Eight large pumps, four primary and four secondary are required for the heat transport systems of the Target Plant, compared to four for the $\mathrm{C}-\mathrm{E}$ System 80. Comparative sketches of the pumps are shown in Figure 4.3 and parameters are compared in Table 4.4 .

The Target Plant uses variable speed pumps to meet the requirement of $40 \%$ to $100 \%$ variable flow which corresponds to the $40 \%$ to $100 \%$ power level range of reactor operation. This requirement for speed variation necessitates the provisions of a speed control mechanism such as a motor-generator set in addition to the main drive motor for each pump.

To avoid a shaft seal against sodium, the pumps have a large surge tank with a free surface of sodium. The shaft seal to retain the cover gas over this free surface must prevent the in-leakage of even minute quantities of air. In the case of the primary pumps, the cover gas may be contaminated with radioactive fission gases, so out-leakage must also be avoided. For this reason (among others) pressurization of the cover gas in the primary pumps (and the reactor vessel) is avoided. The primary pumps particularly must also be designed to operate with low available NPSH.

The sodium pumps have long shafts supported at the lower end by hydrostatic bearings under sodium, and must have provisions for sodium level control in their surge tanks. The primary pumps also require shielding against sodium24 activity.

In comparison, the C-E System 80 uses conventional centrifugal pumps, which are more compact and simpler in design. While the seals must withstand the high system pressure, a small amount of leakage is tolerable and expected. The comparatively heavy case is offset by the compact size. Thermal transients are not a problem, and the pumps operate at constant speed. 

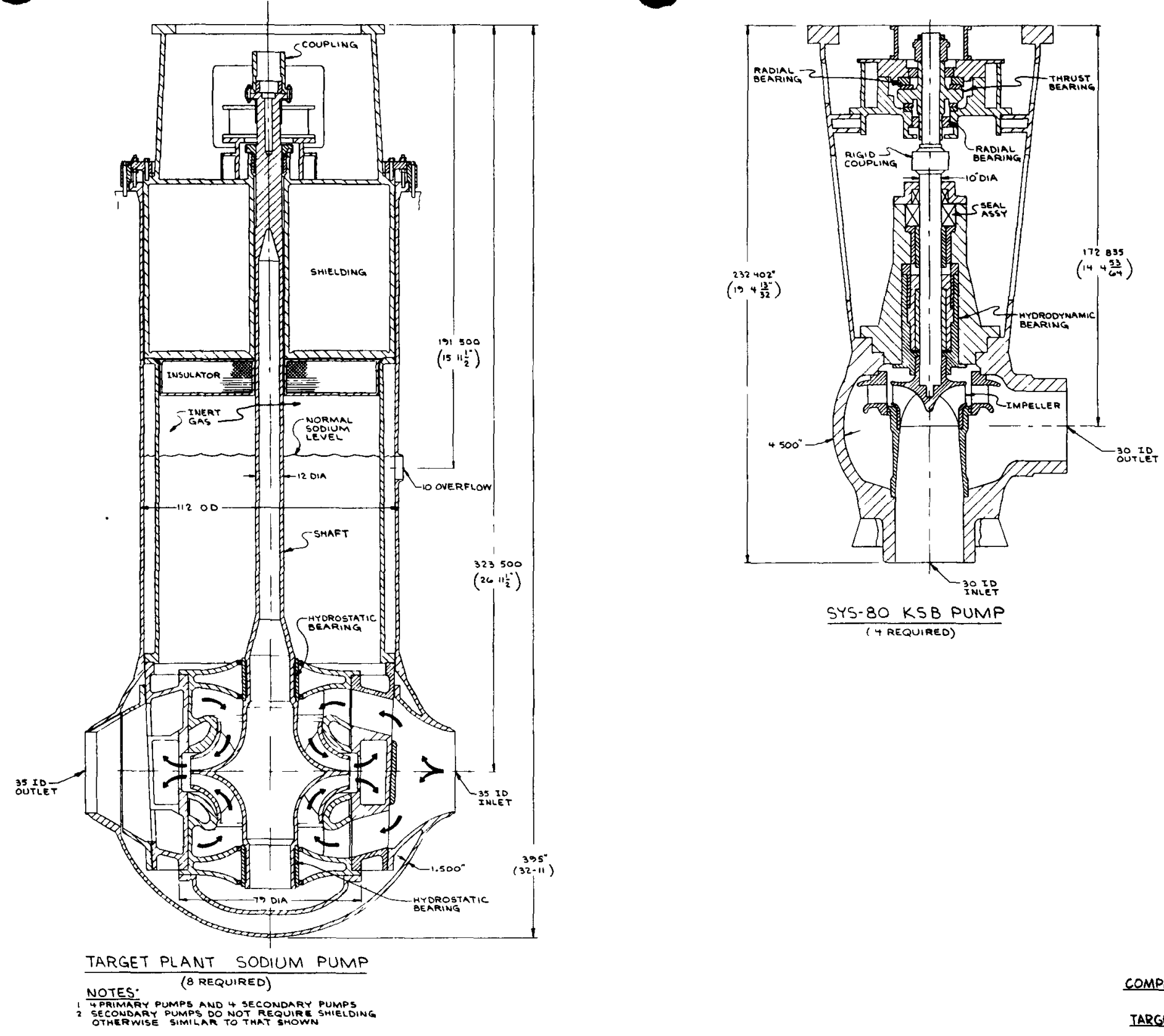

FIGURE 4.3 IARGET PLANT VS CE SYSTEM 80 
TABLE 4.4

COMPARISON OF HEAT TRANSPORT SYSTEM PUMPS

DESCRIPTION

Design Temperature, ${ }^{\circ} \mathrm{F}$

Design Pressure, psia

Flow (GPM)

TDH (Ft.)

Pump Weight (Lbs)

Motor Rating (HP)

Speed Regulator Rating (HP)

Pony Motor/Drive Rating (HP)
PWR

$C-E$

SYSTEM 80

650

2500

111,400

365

121,000

12,000

None

(Constant Speed)

None
LMFBR

TARGET PLANT

Primary Secondary

950

625

165

300

86,200

76,700

363

291

$283,000 \quad 200,000$

$9,000 \quad 6,000$

$9,000 \quad 6,000$

100

100 
A complete and detailed listing of comparative information is provided in Table 4.5; however, certain of the more salient of these comparative data are discussed below. Comparative sketches of the steam generators are shown in Figure 4.4 .

The Systems 80 PWR Plant is of a two-loop/one steam generator per loop configuration. The total weight of steam generating apparatus is approximately 1,430 tons with a total heat transfer area of $249,600 \mathrm{ft}^{2}$. These totals are significantly less than those required for the four-10op/two steam generators per loop configuration of the LMFBR. Total steam geneator weight and heat transfer area for the LMFBR System are approximately 2,600 tons and 401,200 $\mathrm{ft}^{2}$, respectively. At first light, these gross differences seem unjustifiable since the LMFBR shell thicknesses are thin (1.50 to 2.50 inch) compared with those of the much higher pressure PWR Shells (5.63 to 6.88 inch). However, a review of the constituent weights discloses the total plant tubing weight for the LMFBR components to be one of the most significant contributors. Since the LMFBR Steam Generators are combined evaporator/superheater units, the tube wall must be sized to accommodate the high temperature and pressure at the superheater outlet end. Tube wall thickness for the LMFBR Components is 0.125 as compared with 0.042 inch for the PWR Components. This wall thickness is excessive in the evaporator region and thus reduces the heat transfer efficiency throughout a major portion of the heated length of the tube bundle. In addition, the tube pitch is large to facilitate the back side tube-to-tubesheet weld and this influences tubesheet diameter and thickness. It can be concluded that the LMFBR steam generating equipment might be more nearly optimized if the evaporators were separated from the superheaters such that thinner tubes could be used in the evaporator units. (Perhaps a more logical selection might be to utilize two or three parallel evaporators with one or two superheater units per loop, in lieu of the two combined units per loop). 


\section{COMPARISON OF STEAM GENERATORS}

\begin{tabular}{|c|c|c|}
\hline DESCRIPTION & $\begin{array}{r}\text { PWR } \\
\text { C-E } \\
\text { SYSTEM } 80 \\
\end{array}$ & $\begin{array}{c}\text { LMFBR } \\
\text { TARGET PLANT } \\
\end{array}$ \\
\hline Number of Components per plant & 2 & 8 \\
\hline Component Type or Configuration & U-Tube & St. Tube \\
\hline Flow Characteristics & Mixed Flow & Counterflow \\
\hline Orientation & Vertical & Vertical \\
\hline \multicolumn{3}{|l|}{$\begin{array}{l}\text { Shell Side Design and Operating } \\
\text { Conditions }\end{array}$} \\
\hline $\begin{array}{l}\text { Design Pressure/Design Temperature } \\
\text { Flow Rate } \\
\text { Fluid } \\
\text { Inlet Temperature/Outlet Temperature }\end{array}$ & $\begin{array}{l}1270 \mathrm{psia} / 575^{\circ} \mathrm{F*} \\
4.92 \times 10^{*} \mathrm{bm} / \mathrm{hr} \\
\mathrm{H}_{2} 0 \\
450^{\circ} \mathrm{F} / 553^{\circ} \mathrm{F}\end{array}$ & $\begin{array}{l}300 \mathrm{psia} / 935^{\circ} \mathrm{F} \\
16.65 \times 10^{\circ} \mathrm{lbm} / \mathrm{hr} \\
\mathrm{Na} \\
910^{\circ} \mathrm{F} / 590^{\circ} \mathrm{F}\end{array}$ \\
\hline \multicolumn{3}{|l|}{ Tubeside Design and Operating Conditions } \\
\hline $\begin{array}{l}\text { Design Pressure/Design Temperature } \\
\text { Flow Rate } \\
\text { Fluid } \\
\text { Inlet Temperature/Outlet Temperature }\end{array}$ & $\begin{array}{l}2500 \mathrm{psia} 6650^{\circ} \mathrm{F} \\
82.0 \times 10^{\circ} \mathrm{bm} / \mathrm{hr} \\
\mathrm{H}_{2} 0 \mathrm{O} \\
621^{\circ} \mathrm{F} / 565^{\circ} \mathrm{F}\end{array}$ & $\begin{array}{l}2275 \mathrm{psia} / 875^{\circ} \mathrm{F} \\
1.74 \times 10^{\circ} \mathrm{bm} / \mathrm{hr} \\
\mathrm{H}_{2} \mathrm{O} \\
490^{\circ} \mathrm{F} / 854^{\circ} \mathrm{F}\end{array}$ \\
\hline Heat Load per Component & 1900 Mwt & 475 Mwt \\
\hline Safety Class & Section III, $\mathrm{Cl} .182^{\star \star \star}$ & Section VIII, Div. 2 \\
\hline \multicolumn{3}{|l|}{ Physical Size and Weight } \\
\hline $\begin{array}{l}\text { Maximum Diameter (She11) } \\
\text { Overall Length } \\
\text { Dry Weight - Per Component/Per Plant }\end{array}$ & $\begin{array}{l}243.75^{\prime \prime} \\
68^{\prime}-6.25^{\prime \prime} \\
1,552,800 / 3,105,600 \text { lbs }\end{array}$ & $\begin{array}{l}106^{\prime \prime} \cdot 75^{\prime \prime} \\
88^{\prime}-8.0^{\prime \prime} \\
648,000 / 5,184,000 \text { Lbs }\end{array}$ \\
\hline \multicolumn{3}{|l|}{ Materials } \\
\hline $\begin{array}{l}\text { Shell Plate } \\
\text { Tubesheet(s) } \\
\text { Tubes }\end{array}$ & $\begin{array}{l}\text { SA-533, Gr. A \& Gr. B } \\
\text { SA-508, C1. } 3 \\
\text { SB-163 }\end{array}$ & $\begin{array}{l}\text { SA-387, Gr. } 22, \mathrm{Cl} .1 \\
\text { SA-336 F22 } \\
\text { SA-213, Gr. T22 }\end{array}$ \\
\hline
\end{tabular}

* Except for lower head and tubesheet which have the same design pressure and temperature as the tubeside.

**Primary side is Class 1 and secondary side is Class 2. 
TABLE 4.5 (Cont'd)

PWR

$C-E$

COMPARISON OF COMPONENT SHELLS SYSTEM 80

LMFBR

TARGET PLANT

Shell Plate Thicknesses

Upper Cylindrical Shell Region

$5.88^{\prime \prime}$

$6.88^{\prime \prime}$

$5.63^{\prime \prime}$

Lower Cylindrical Shell Region

$4.25^{\prime \prime}$

Steam Outlet Hemispherical Head

None

Upper Sodium Hemispherical Head

$8.19^{11}$

$2.50^{\prime \prime}$

None

$1.50^{\prime \prime}$

$5.50^{\prime \prime}$

$1.50^{\prime \prime}$

Lower Hemispherical Head

$5.00^{\prime \prime}$

Internal Cladding

Location

Material/Thickness

Lower Head None

S.S./0.19" None

Nozzles

Shell Side Inlet - Qty./I.D.

$2 / 14.00^{\prime \prime}$

$2 / 28.00^{\prime \prime}$

$1 / 42.00^{\prime \prime}$

Tube Side Inlet - Qty./I.D.

$2 / 30.00^{\prime \prime}$

Tube Side Outlet- Qty./I.D.

Access Ports or Manways - Qty./I.D.4/16.00"
Handholes - Qty./I.D.

Linear Feet of Welds

$560 \mathrm{ft}$.

$1 / 25.00^{\prime \prime}$

$1 / 25.00^{\prime \prime}$

$1 / 18.00^{\prime \prime}$

$1 / 18.00^{\prime \prime}$

$2 / 24.00^{\prime \prime}$

None

$310 \mathrm{Ft}$.

\section{COMPARISON OF COMPONENT TUBE BUNDLES}

\section{Number of Tubes - per Comp./ per Plant}

Mean Heated Length

Tube Size-0D/Wall Thickness/Pitch

Heat Transfer Area-Per Comp./ per Plant

Tube Support Concept

Type of Tube-to-Tubesheet Weld

Tube Bundle Shroud

Inside Diameter

Thickness

Length
$11,012 / 22,024$

$57^{\prime}-8.64^{\prime \prime}$

$0.75^{\prime \prime} / 0.042^{\prime \prime} / 1.000^{\prime \prime}$

$124,800 \mathrm{Ft}^{2} / 249,600$

Eggcrate

Rolled \& Face Side

$168.50^{\prime \prime}$

$1.25^{\prime \prime}$

$37^{\prime}-11.25^{\prime \prime}$
$3,547 / 28,376$

$72^{\prime}-0^{\prime \prime}$

$0.75^{\prime \prime} / 0.125^{\prime \prime} / 1.250^{\prime \prime}$

$50,145 \mathrm{ft}^{2} / 401,160 \mathrm{Ft}^{2}$

Drilled Plates

Face \& Back Side

$80.88^{\prime \prime}$

$1.00^{\prime \prime}$

$67^{\prime}-6.00^{\prime \prime}$ 


\section{TABLE 4.5 (Continued)}

\begin{tabular}{|c|c|c|}
\hline COMPARISON OF COMPONENT TUBE SHEETS & $\begin{array}{r}\text { PWR } \\
\text { C-E } \\
\text { SYSTEM } 80 \\
\end{array}$ & $\begin{array}{c}\text { LMFBR } \\
\text { TARGET PLANT } \\
\end{array}$ \\
\hline Number per Component & 1 & 2 \\
\hline Finished Diameter - Upper/Lower & 185.76"/None & $101.00 " / 101.00 "$ \\
\hline Finished Thickness - Upper/Lower & $23.50 " /$ None & $26.00^{\prime \prime} / 23.00 "$ \\
\hline $\begin{array}{l}\text { Clad Material/Clad Thickness } \\
\text { COMPARISON OF CONSTITUENT WEIGHTS }\end{array}$ & S.S./0.25" & None/None \\
\hline \multicolumn{3}{|l|}{ Weight of Shell (Pressure Boundary) } \\
\hline $\begin{array}{l}\text { Plate Material } \\
\text { Nozzles, Access Ports, Manways, Etc. } \\
\text { Weight of Weld Metal } \\
\text { Total Weight of She11 }\end{array}$ & $\begin{array}{l}520,300 \text { Lbs } \\
46,800 \text { Lbs } \\
16,200 \text { Lbs } \\
583,300 \text { Lbs }\end{array}$ & $\begin{array}{l}161,000 \text { Lbs } \\
18,300 \text { Lbs } \\
2,400 \text { Lbs } \\
181,700 \text { Lbs }\end{array}$ \\
\hline \multicolumn{3}{|l|}{ Weight of Tube Bundle } \\
\hline $\begin{array}{l}\text { Tubing } \\
\text { Tube Supports } \\
\text { Shrouds } \\
\text { Total Weight of Tube Bundle }\end{array}$ & $\begin{array}{l}233,750 \text { Lbs } \\
31,500 \text { Lbs } \\
82,900 \text { Lbs } \\
348,150 \text { Lbs }\end{array}$ & $\begin{array}{l}226,700 \text { Lbs } \\
30,300 \text { Lbs } \\
66,100 \text { Lbs } \\
323,100 \text { Lbs }\end{array}$ \\
\hline \multicolumn{3}{|l|}{ Weight of Tubesheets } \\
\hline $\begin{array}{l}\text { Upper } \\
\text { Lower } \\
\text { Total Weight of Tubesheets }\end{array}$ & $\begin{array}{l}\text { None } \\
124,100 \text { Lbs } \\
124,100 \text { Lbs }\end{array}$ & $\begin{array}{l}49,100 \text { Lbs } \\
36,600 \text { Lbs } \\
82,700 \text { Lbs }\end{array}$ \\
\hline \multicolumn{3}{|l|}{ Weight of Steam Separation Equipment } \\
\hline $\begin{array}{l}\text { Weight of Separators } \\
\text { Weight of Dryers } \\
\text { Weight of Supports } \\
\text { Total Weight of Steam Separator Equip. }\end{array}$ & $\begin{array}{l}26,000 \text { Lbs } \\
11,300 \text { Lbs } \\
37,700 \text { Lbs } \\
75,000 \text { Lbs }\end{array}$ & $\begin{array}{l}\text { None } \\
\text { None } \\
\text { None } \\
\text { None }\end{array}$ \\
\hline \multicolumn{3}{|l|}{ Miscellaneous Parts } \\
\hline Total Weight of Miscellaneous Parts & 422,250 Lbs & 60,500 Lbs \\
\hline
\end{tabular}


It should be borne in mind that the LMFBR Steam Generator by necessity requires a high degree of integrity to prevent sodium water reactions. The tube-to-tubesheet joint selected for use in these units provides this high integrity and will perhaps always be the limiting factor in determining tube wall thicknesses.

In regard to configuration comparisons, the LMFBR Steam Generators are straight-tube straight-shell counterflow units which should be more efficient than the U-tube configuration of the PWR. The tube-to-tubesheet welds, thermal liners, etc., along with the larger number of components make the LMFBR components more complicated from a fabrication point of view.

\section{Expansion Tanks/Pressurizer}

There is no component within the PWR for direct comparison with the Secondary Sodium Expansion Tank; however, for the purpose of this study, it was decided that a comparison with the PWR pressurizer might be in order. There is one pressurizer in a PWR System while there are four Secondary Sodium Expansion Tanks. Comparative parameters of the two components are shown in Table 4.6 .

Physically the expansion tanks are approximately one-third the height of the pressurizers and have much thinner walls due to the difference in design pressure (300 psia for the expansion tank and 2500 psia for the pressurizer). Thus, the four expansion tanks weigh approximately the same as one pressurizer, have much less poundage of weld metal, and a much larger total linear footage of weld seams.

As stated in the design description in Section 2, the expansion tank is a Section VIII, Division 2, Vessel while the pressurizer is a Section III, Class 1, vessel. The expansion tank is fabricated from stainless steel and the pressurizer is primarily made from SA-533, Grade A, Class 1, material with stainless steel clad over the entire inner surface of the vessel. 


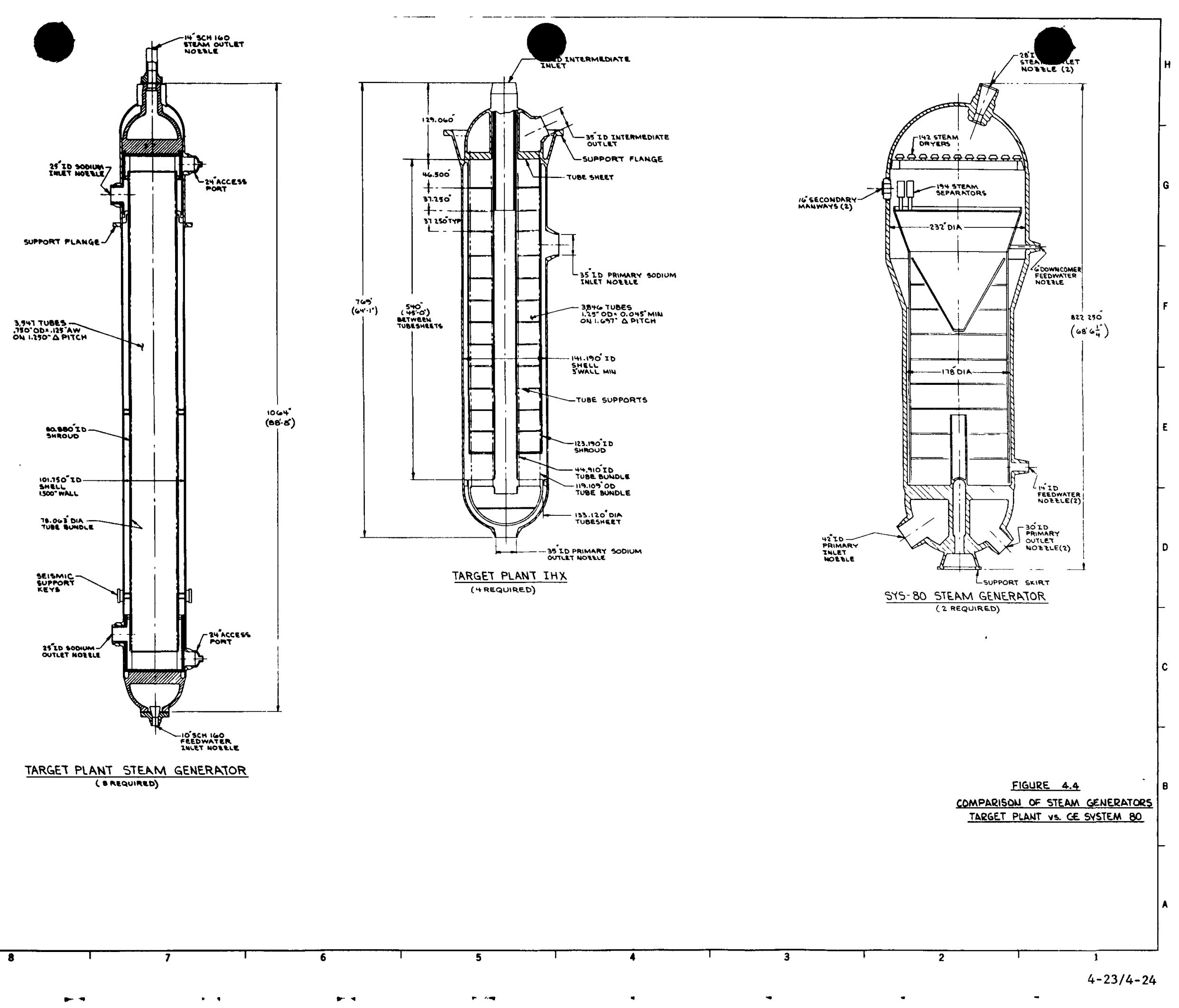


TABLE 4.6

COMPARISON OF SECONDARY SODIUM

EXPANSION TANK AND PWR PRESSURIZER
PWR
C-E
SYSTEM 80

Number of Components per Plant

14

Design and Operating Conditions

Design Pressure/Temperature

Fluid

$\begin{array}{ll}2500 \mathrm{Psia} / 700^{\circ} \mathrm{F} & 300 \mathrm{Psia} / 600^{\circ} \mathrm{F} \\ \mathrm{H}_{2} \mathrm{O} & \mathrm{Na} \\ 1800 \mathrm{KW} & \text { None } \\ \text { Section III, Cl. } 1 & \text { Section VIII, Div. 2 }\end{array}$

Physical Size and Weight

Maximum Diameter (Shel1)

$106.25^{\prime \prime}$

$123.26^{\prime \prime}$

$42^{\prime}-5.63^{\prime \prime}$

$15^{\prime}-11.63^{\prime \prime}$

Dry Weight

221,800 Lbs

47,900 Lbs

Material

Shell Plate

Supoort Skirt

SA-533, Gr. A, C1. 1

304 SS

$S A-516$

None

Support Flange

$S A-516$

304 SS

COMPARISON OF COMPONENT SHELLS

Shell Plate Thicknesses

Cylindrical Shell Region

Upper and Lower Heads

$5.00^{\prime \prime}$

$1.63^{\prime \prime}$

$4.00^{\prime \prime}$

$1.63^{\prime \prime}$

Internal Cladding

Location

Material/Thickness

Entire Inner Surface None

S.S./0.19" None

Nozzles and Manways

Total Number

Range of Inside Diameters

Manway - Qty./Size

Heater Penetrations - Qty.

Instrument Nozzles - Qty.

8

3.63" thru 9.63"

$1 / 76.00^{\prime \prime}$

36

6

6

$2.00^{\prime \prime}$ thru $4.00 "$

$1 / 16.00^{\prime \prime}$

None

None

Lineal Feet of Welds

$135 \mathrm{Ft}$. 
TABLE 4.6 (Continued)

\begin{tabular}{|c|c|c|}
\hline COMPARISON OF CONSTITUENT WEIGHTS & $\begin{array}{r}\text { PWR } \\
\text { C-E } \\
\text { SYSTEM } 80 \\
\end{array}$ & $\begin{array}{c}\text { LMFBR } \\
\text { TARGET PLANT } \\
\end{array}$ \\
\hline \multicolumn{3}{|l|}{ Weight of Shell } \\
\hline $\begin{array}{l}\text { Shell Plate } \\
\text { Nozzles and Manways } \\
\text { Weld Metal } \\
\text { Support Skirt } \\
\text { Support Flange } \\
\text { Total Weight of Shell }\end{array}$ & $\begin{array}{l}201,000 \text { Lbs } \\
2,400 \text { Lbs } \\
5,500 \text { Lbs } \\
7,400 \text { Lbs } \\
2,300 \text { Lbs } \\
218,600 \text { Lbs }\end{array}$ & $\begin{array}{l}35,300 \text { Lbs } \\
850 \text { Lbs } \\
650 \text { Lbs } \\
\text { None } \\
11,000 \text { Lbs } \\
47,800 \text { Lbs }\end{array}$ \\
\hline \multicolumn{3}{|l|}{ Weight of Miscellaneous Parts } \\
\hline Total Weight of Miscellaneous $P$ & 3,200 Lbs & 100 Lbs \\
\hline
\end{tabular}


A large portion of the capital cost of the Target Plant is associated with heat transport piping. This large amount of piping between the heat transport components is required for piping flexibility, while the components are rigidly fixed. The C-E System 80 pumps and heat exchangers have sliding supports and do not require any significant amount of piping. The piping, valves and fitting estimates for the two plants are summarized in Table 4.7 .

Safeguards Cooling Systems

The safeguards cooling systems provide emergency cooling capability in the event the main heat transport systems are unable to function. The safeguards systems for the two plants are different in function and design due to generic differences between the LMFBR and the LWR. Also there are significant differences in the events against which protection is provided by these safeguards systems.

For the LWR, a guillotine rupture at the reactor inlet produces a loss of coolant accident and results in rapid depressurization of the reactor vessel. The LWR safeguards cooling systems are, therefore, designed to flood the reactor vessel with additional coolant to prevent loss of a coolable core geometry and to maintain fuel temperatures at a safe level.

There are two safeguards cooling systems for the LWR, i.e., a High Pressure Coolant Injection System (HPCIS) and a Low Pressure Coolant Injection System (LPCIS). The HPCIS injects borated water into the reactor vessel at high pressures and protects the reactor for small leaks. The LPCIS provides cooling water to the reactor vessel from the refueling water tank or from the reactor vessel for events which are beyond the capability of the HPCIS. Both systems utilize multiple pumps and flow paths for redundancy and reliability. This results in relatively high capital cost of the LWR safeguards systems due to their large number of components and complexity of design. 


\begin{tabular}{|c|c|c|}
\hline DESCRIPTION & $\begin{array}{c}\text { PWR } \\
\text { C-E } \\
\text { SYSTEM } 80 \\
\end{array}$ & $\begin{array}{c}\text { LMFBR } \\
\text { TARGET PLANT } \\
\end{array}$ \\
\hline Material & C.S. & S.S. \\
\hline Max. Design Temperature, ${ }^{\circ} \mathrm{F}$ & 650 & 970 \\
\hline Max. Design Pressure, Psia & 2500 & 300 \\
\hline Piping Runs & $\begin{array}{l}52^{\prime \prime} \phi-27^{\prime} \\
36^{\prime \prime} \phi-183^{\prime} \\
12^{\prime \prime} \phi-63^{\prime}\end{array}$ & $\begin{array}{l}44^{\prime \prime} \phi-350^{\prime} \\
36^{\prime \prime} \phi-1450^{\prime} \\
26^{\prime \prime} \phi-850^{\prime} \\
14^{\prime \prime} \phi-250^{\prime}\end{array}$ \\
\hline Total Large Piping & $273^{\prime}$ & $2900^{\prime}$ \\
\hline Elbows (Number) & $\begin{array}{l}52 " \phi-2 \\
36 " \phi-16\end{array}$ & $\begin{array}{l}44 " \phi-28 \\
36^{\prime \prime} \phi-104 \\
26^{\prime \prime} \phi-64 \\
14^{\prime \prime} \phi-16\end{array}$ \\
\hline Total Large Fittings & 18 & 212 \\
\hline Valves (Number) & None & $\begin{array}{l}44 " \phi-4 \\
36 " \phi-72 \\
14 " \phi-4\end{array}$ \\
\hline Total Large Valves & None & 20 \\
\hline
\end{tabular}


The low pressure design of the LMFBR minimizes possibility of a pipe rupture and makes the cooling system design less complex than that of the LWR. A normal scram occurs upon loss of flow from the main heat transport systems due to control interlocks. The safeguards cooling system for the LMFBR, called the Auxiliary Heat Transfer System (AHTS), therefore, is used to remove decay heat from the reactor. The AHTS consists of two independent and diverse loops; each utilizes EM pumps, straight tube $\mathrm{Na}$ to NaK heat exchangers and air blast heat exchangers for decay heat removal.

The LWR safeguards cooling systems are somewhat more complex and expensive than the LMFBR AHTS, mainly due to the multiple high pressure systems. The LMFBR AHTS are simple and less expensive due to low pressure systems and superior heat transfer characteristics of sodium. Further cost reductions are also possible through improvement in technology and mass production of the sodium components.

Fuel Handling and Storage System

Comparison of the refueling schemes of the C-E System 80 and the Target Plant can be carried out by considering the refueling procedure for the two plants. Refueling schemes for the LMFBR designs are not as firmly fixed as those of LWR reactors. It is, however, felt that the Target Plant refueling system is representative of a typical LMFBR refueling plan both in concept and in cost. High LMFBR refueling costs reflect the penalties due to the reactive sodium coolant. A sealed environment complete with a forced convection cooling system is required for transport of spent subassemblies, and fuel handling operations must be performed remotely. Refueling at high temperatures places restrictions on machine fabrication due to differential thermal expansion. A separate sodium tank is required to dissipate decay heat.

Auxiliary Systems

A comparison between the auxiliary systems used for the Target Plant and the C-E System 80 to maintain the purity and volume of the coolant is of interest. For the Target Plant this is called the Liquid Metal Purification 
System (LMPS). It processes $60 \mathrm{gpm}$ of primary sodium through a regenerative heat exchanger and cold trap before returning the flow to the primary coolant stream. A similar system processes $70 \mathrm{gpm}$ for each loop of the secondary system. The main concern on the primary heat transport system is oxygen in-leakage since this system is at low pressure, whereas on the secondary side, a major concern is hydrogen diffusion through the steam generators. Process sodium in the cold trap is cleaned by precipitating out oxidized sodium and other impurities onto stainless steel filters. The cold traps themselves are cooled with NaK, and various impurities are removed from the NaK via diffusion cold traps.

For the C-E System 80 , the comparable system is called the Chemical Volume Control System (CVCS). It processes $84 \mathrm{gpm}$ in normal operation through a regenerative heat exchanger, particulate filters and ion exchangers and returns this flow to the main line after obtaining the necessary boron concentration for reactivity control. In this system, chemicals such as hydrazine and hydrogen gas are added to prevent halide-induced corrosion and oxide formation. In addition, provision is made for the removal of fission gas from the coolant. Degassing the coolant and maintaining proper boron chemistry impose significant costs on this system. 0ther parts of the system such as the refueling water tank are included under this classification because these parts must allow boric acid recycle.

Purification levels for each system reflect the different requirements of their designs. While both systems can suffer from corrosion problems, the LWR system prevents stainless steel stress corrosion whereas the LMFBR system must protect against mass transport from regions of high temperature to regions of low temperature. The differing emphasis is system dependent, arising from the high-pressure, low-temperature LWR environment and the low-pressure, high-temperature LMFBR environment.

The flow path for both purification systems are similar. Both draw a process stream from the cold leg of each of their respective coolant loops. This stream is then cooled, filtered and returned to the main coolant flow. For the LWR, some additional equipment is needed to maintain proper boron 
control, to minimize coolant radioactivity, and to remove any free hydrogen or oxygen. The gas stripping equipment accounts for a considerable fraction of the CVCS cost.

Pumps used in the CVCS provide circulation, makeup, chemical control, and drain services. Pumps used to send processed coolant back to the main steam are designed for high pressure service and are the most expensive pumps per unit horsepower in the LWR system. Three pumps are required for maintenance and redundancy. Makeup pumps are used to return water from the makeup tank to the main coolant stream. The extra water in this tank allows total recycle, i.e. dilution of borated water to compensate for the loss in reactivity as the fuel is burned. These pumps are low pressure, low temperature and low horsepower and are farily inexpensive. Additional pumps are used to maintain proper water chemistry in the coolant system, bringing the total number of pumps used in the CVCS to 11.

The LMFBR purification system uses pumps for volume control and purification of the primary heat transport system, purification of the intermediate heat transport system, and for cooling the sodium cold trap filters. The overflow pump draws sodium from the overflows tank and sends it through a cold trap before the stream returns to the main loop. There is no need for drain or high pressure pumps in this system because of the low pressure, nor is there any requirement to degas the coolant in a separate component. The secondary loop also has cold trap pumps for each loop in the event that the loop sodium inventory becomes contaminated. Finally, the cooling of all cold trip with NaK requires a set of NaK pumps. In a 11, 10 LMFBR purification pumps are required. Although the pumping power required for the liquid metal pumps is lower (by a factor of 2.5) than for the LWR pumps, the cost of these pumps is higher by a factor of 2 . The reason for this difference is in large part the non-commercial manufacture of electromagnetic pumps. Economies associated with larger pumps could not be specified as only a discrete set of EM pumps have been made; the pumps selected for the Target Plant did not always meet the specifications of current EM pumps, thus producing a cost penalty. The large differential between LMFBR EM pumps and LWR mechanical pumps used in purification will almost certainly be narrowed in the commercial phase of the LMFBR. 
Heat exchangers used in the CVCS cool the incoming fluid to a temperature suitable for the long term operation of the purification system. These are both regenerative and letdown heat exchangers acting in series prior to purification. The regenerative heat exchanger is a high-pressure, hightemperature unit because it interfaces with the main heat transport system. The letdown heat exchanger is less expensive because its design requirements are less stringent. Both heat exchangers are of stainless steel she11-andtube design. The design calls for two regenerative heat exchangers and one letdown heat exchanger.

A greater number of purification heat exchangers is required for the LMFBR as all heat transfer loops are designed to be independent. Thus, each primary and secondary loop has its own heat exchanger to cool the process stream prior to purification. These units are also of shell-and-tube design with a somewhat higher design temperature than the LWR regenerative heat exchangers. A11 units are 304 SS. The LMFBR heat exchangers are more expensive than their LWR counterparts for the purification system, but it is anticipated that these cost penalties would become smaller in the commercial stage of the LMFBR. The total cost of LMFBR heat exchangers in the purification system exceeds that of the LWR by a factor of 3. Part of this differential is due to the greater number of heat exchangers specified for the LMFBR, and the cost per unit surface area for LMFBR heat exchangers is also higher than the LWR units.

Filters for the LWR system include purification strainers, ion exchangers, and gas strippers. The filters are stainless steel, particulate mesh, types designed for trapping particles 2 microns and larger. Lithium and ionic radionuclides are removed from the process stream in mixed bed ion exchangers. A gas stripper is also utilized to remove hydrogen produced by nuclear heating. Some of the purification apparatus is clearly due to the use of water as reactor coolant.

Trapping of the particulates in the LMFBR coolant stream employs closepacked mesh filters and additional coolant of the process stream to precipitate 
out components of sodium with oxygen, hydrogen, carbon and other impurities. Design temperature for this equipment is somewhat higher than for the LWR filters. Costs quoted for the Target Plant cold traps are for off-theshelf units and significant cost reductions are expected for commercial LMFBR plants. For purification units the cost of the LMFBR system exceeds that of the LWR system by a two-to-one ratio.

Storage requirements for the LWR purification system exceed those of the LMFBR design due to the boron deletion requirements. Holdup and makeup tanks are large, field-fabricated vessels holding about 400,000 gallons of borated water. Estimates of capital costs of these vessels were unavailable, but their cost is expected to exceed the cost of LMFBR purification tankage, which consists essentially of the primary overflow tank.

Purification costs for the Target Plant exceed those of the C-E System 80 by about 2 to 1 , not including the large field fabricated tanks. Although these quotations were received from vendors, there is reason to believe the cost differential may be reduced. These reductions should come about by commercialization and possibly by a reduction in design requirements.

Heat Transfer Area

A comparative summary of heat transfer areas required for the two plants is given in Table 4.8. As expected, the heat transfer area required for the Target Plant is approximately twice that of the C-E System 80 . This is mostly due to the intermediate sodium loop required between the radioactive primary sodium loop and the feedwater/steam system.

Storage Tanks

A comparative summary for volume of storage tanks is given in Table 4.9 . The storage tanks is given in Table 4.9. The aggregate tank volumes for the two plants are similar. However the tanks for the Target Plant are for high temperature sodium systems and must be engineered and fabricated to relatively high standards. 
TABLE 4.8

\section{COMPARISON OF HEAT TRANSFER AREA}

COMPONENT

Intermediate Heat Exchangers

Steam Generators

Safeguard Heat Exchangers

Safeguards Air Blast Heat Exchangers

Refueling Heat Exchangers

Refueling Air Blast Heat Exchangers

Purification Heat Exchangers
PWR C-E SYSTEM 80

Units HT Area $\left(\mathrm{Ft}^{2}\right)$

2

$-$

249,600

2

13,400

92,700

2

$$
4,400
$$$$
-
$$

3
LMFBR TARGET PLANT

Units Total HT Area $\left(F t^{2}\right)$

4

226,400

8

401,100

2

5,000

2

16,000

2

600

2

1,900

11

1,700

361,200

652,700 
TABLE 4.9

COMPARISON OF STORAGE TANK VOLUMES

SYSTEM

Heat Transport System

Safeguards System

Fuel Handling

Purification

Coolant Storage

Inert Gas
PWR C-E SYSTEM 80

Total Tankage

Units Gallons

16,700

4

72,000

1

590,000

9

458,100

1

450,000

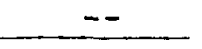

$1,576,800$
LMFBR TARGET PLANT

Total Tankage

Units Gallons

5

222,600

2

4,800

2

300

4

300

19

950,800

27

151,100

$1,329,900$ 
Major differences between the two plants emanate from the choice of different coolants, i.e., water vs liquid metal, necessitated by the core specific power, neutron energy spectrum and operating temperatures and pressures.

High temperatures and low pressures attendant with liquid metals in the LMFBR lead to selection of thin-walled stainless steel components, whereas thick-walled carbon steel components are suitable for low temperature, high pressure water systems for the C-E System 80 Plants.

Utilization of liquid metals in the LMFBR necessitates remote control of fuel handling and component maintenance, inert atomsphere, appropriate shielding and trace heating of the systems. An intermediate heat transfer loop is also required for physical separation between the radioactive primary sodium and the water side of the steam generator system, accounting for additional heat transfer area, piping and components.

As discussed in the preceding paragraphs the high cost difference areas for the Target Plant are:

- Reactor Vessel and closure head

- Heat Transport System

- Refueling System

- Auxiliary System

The reactor vessel as designed reflects limited optimization, and some cost reductions are possible with further optimization. But there does not appear to be a ready solution to the higher cost of LMFBR reactor vessels because most of the design requirements are mandated by the use of liquid metals at high temperatures. Utilization of alternate materials of construction is a possibility. One such material is super-chrome ferritic steel which has high strength and low creep and fatigue damage characteristics and may be suitable after it has been code approved. 
The heat transfer system which contribute significantly to the higher cost of the LMFBR are also mandated by the coolant characteristics. To change this cost picture, the amount and complexity of the piping and components required must be modified. The following are the possibilities for such modifications.

- Use pool-type LMFBR instead of loop-type

- Use bellows joints instead of expansion loops for sodium piping

- Use Super-chrome ferritic steel instead of stainless steel for sodium components such as steam generators, IHX, piping etc.

The refueling system costs are to a great degree dependent on the coolant characteristics and the level of radioactivity in the spent fuel assemblies. One way of simplifying would be the inclusion of a transfer station between the EVST and the reactor vessel for off-loading the assemblies from the transfer pots prior to installation into the EVST. This would have the following effects; (1) It would reduce the number of transfer pots from the present level of one for every assembly in the reload to one or two, (2) It would permit a smaller EVST. This change would be offset somewhat by the cost of a transfer station and the need for another grapple and hoist.

Some reductions in the capital cost of the auxiliary systems are possible with improvements in the system design and with the availability of improved commercial cost data of the sodium components. These would come about through additional design effort to delineate system design and collection of cost data through industry contacts.

Uverall, the present estimate of the capital costs of the Target Plant NSSS contains potential for cost reductions in all major systems. These cost reductions in the capital cost are possible through optimization of system and component design, utilization of innovative concepts and improved collection of commercial cost data for LMFBR components. 


\section{SECTION 5}

\section{DRAWINGS}

This section contains the drawings for the 1390 Mwe LMFBR Target Plant described in Section 2. These drawings are the General Arrangement Drawings for the Target Plant.

Figure Title

5.1 Reactor Containment and PHTS Plan View

5.2 Reactor Containment and PHTS Elevation

5.3

5.4

5.5

5.6

5.7

5.8

\section{Steam Generator Building and IHTS Plan View} Steam Generator Building and IHTS Elevation Reactor Service Building Layout Reactor Service Building Sectional Elevation SE-651410-160-012 Auxiliary Building Plan View Auxiliary Building Elevation
Drawing

SE-651410-160-010

SE-651410-160-004

SE-651410-160-007

SE-651410-160-006

SE-651410-160-011

SE-651410-160-013

SE-651410-160-014 


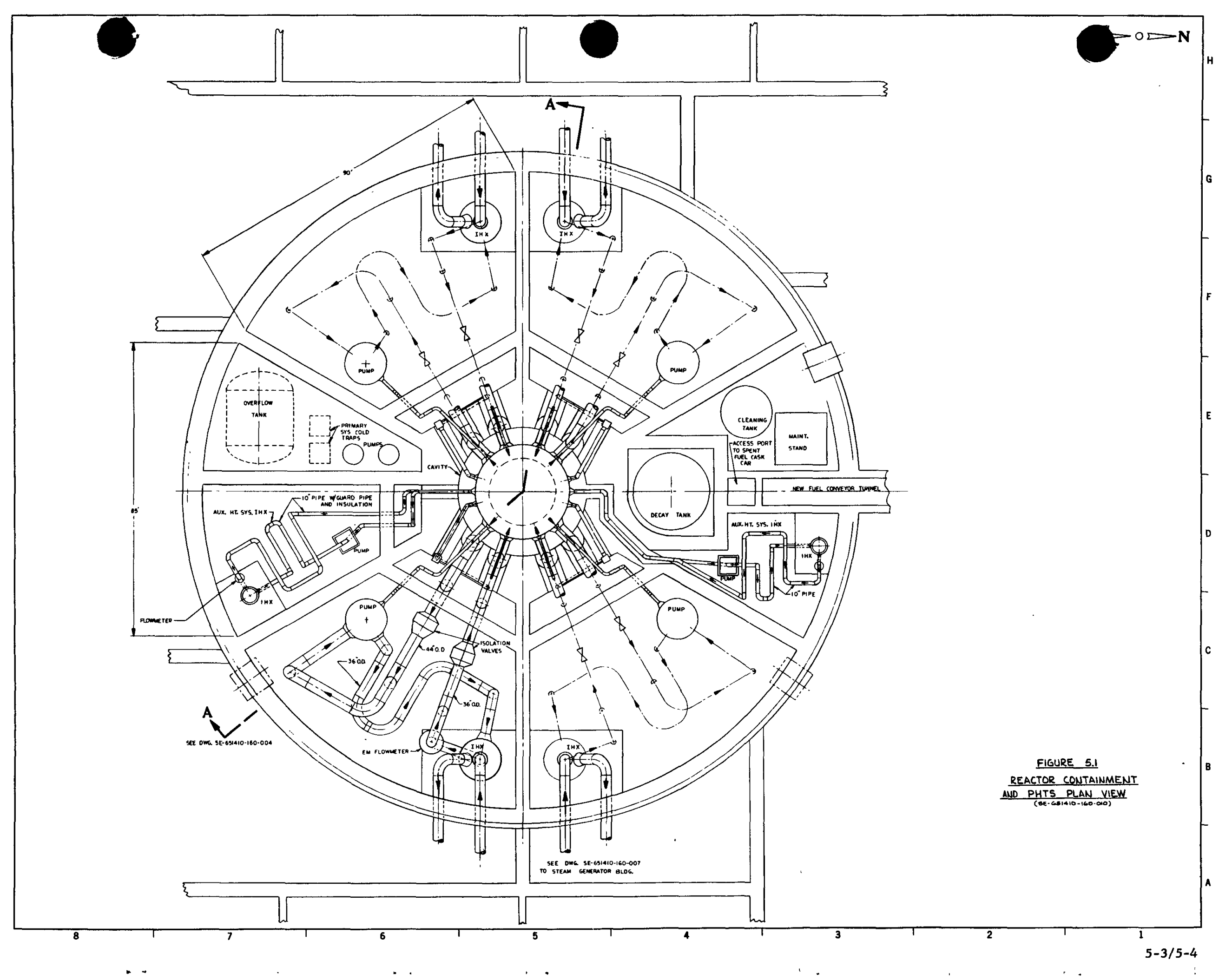




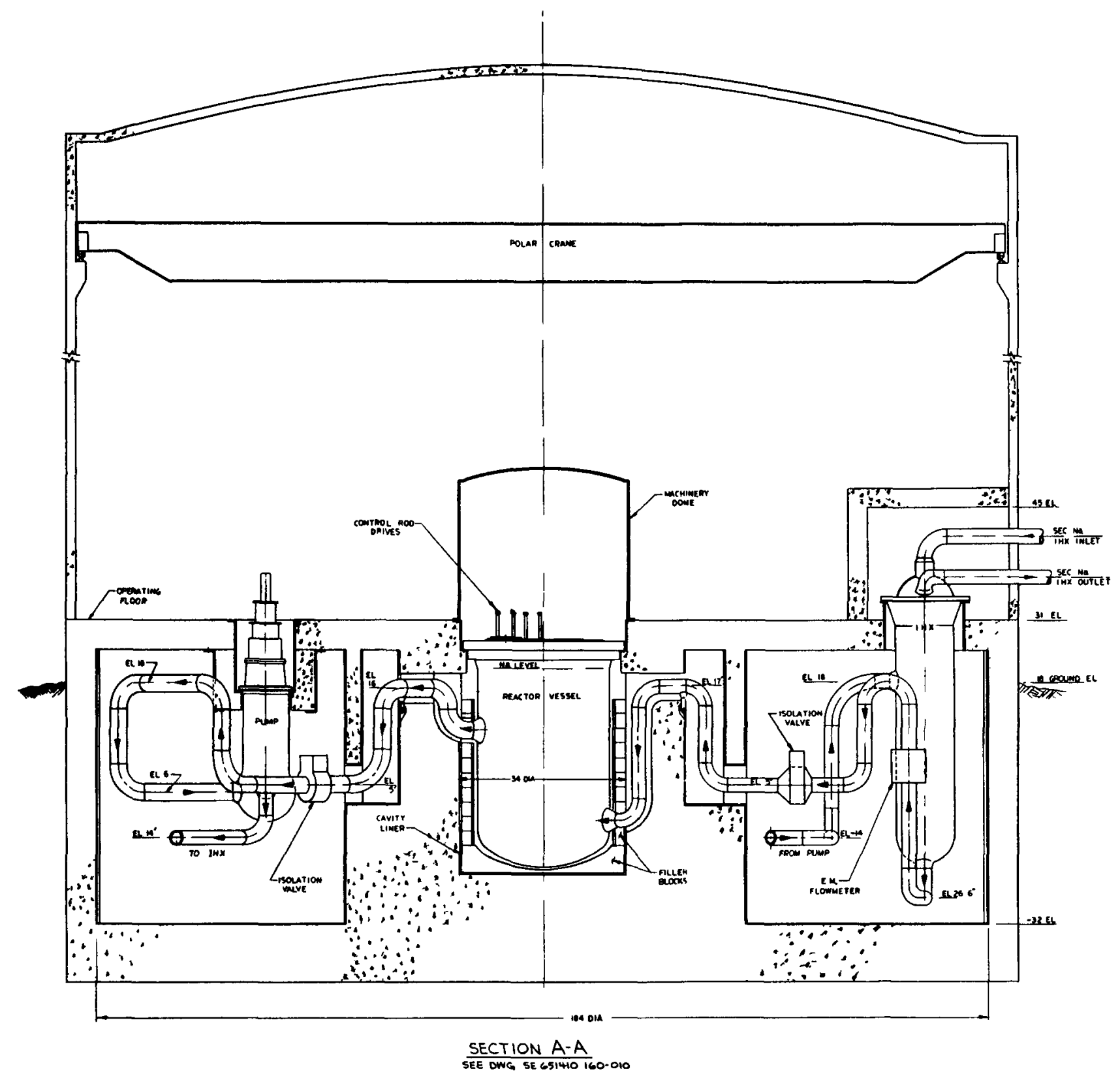

FIGURE 52 REACTOR CONTAINMENT AND PHTS ELEVATION

SECTION SE G51410 150.010 


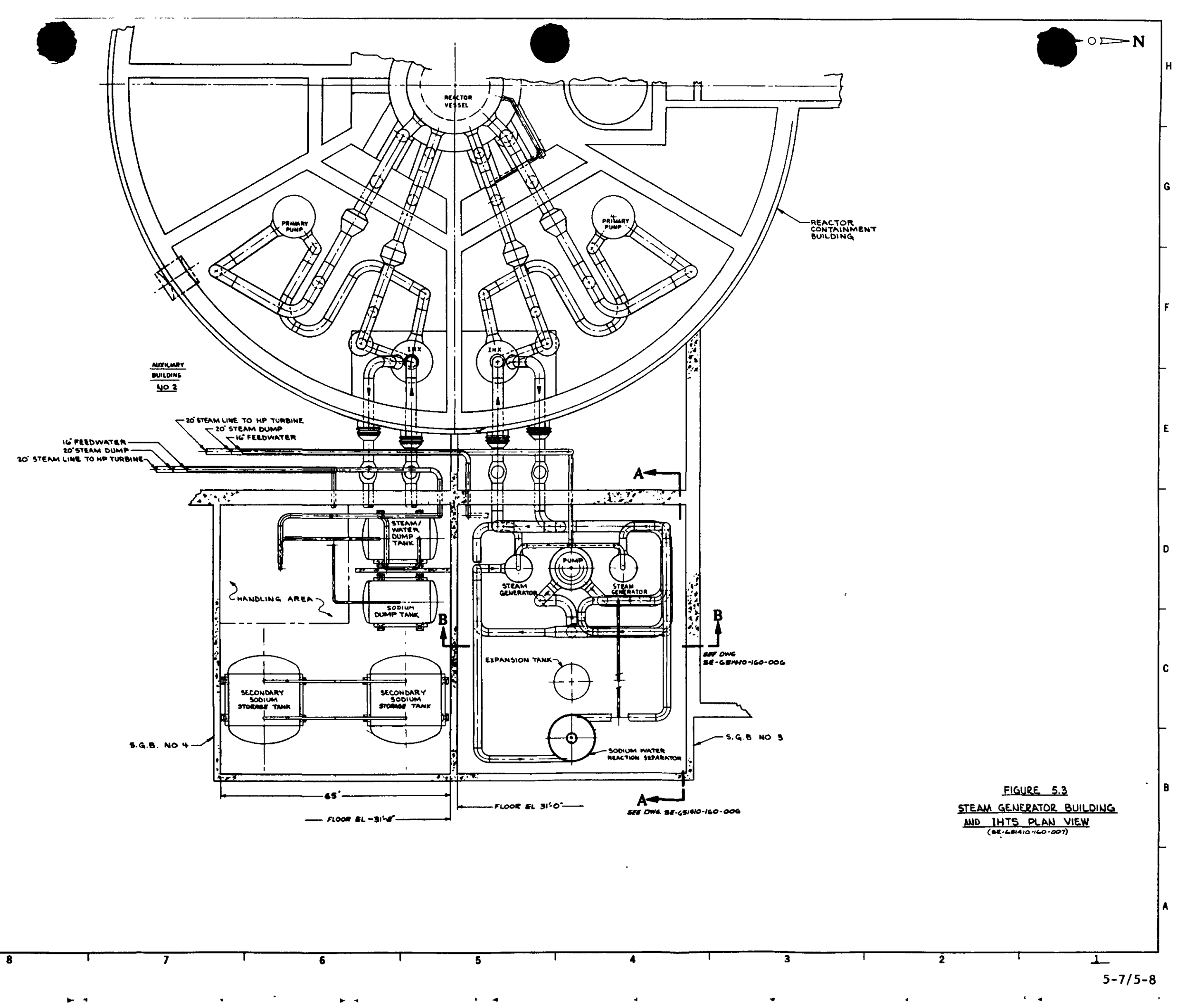




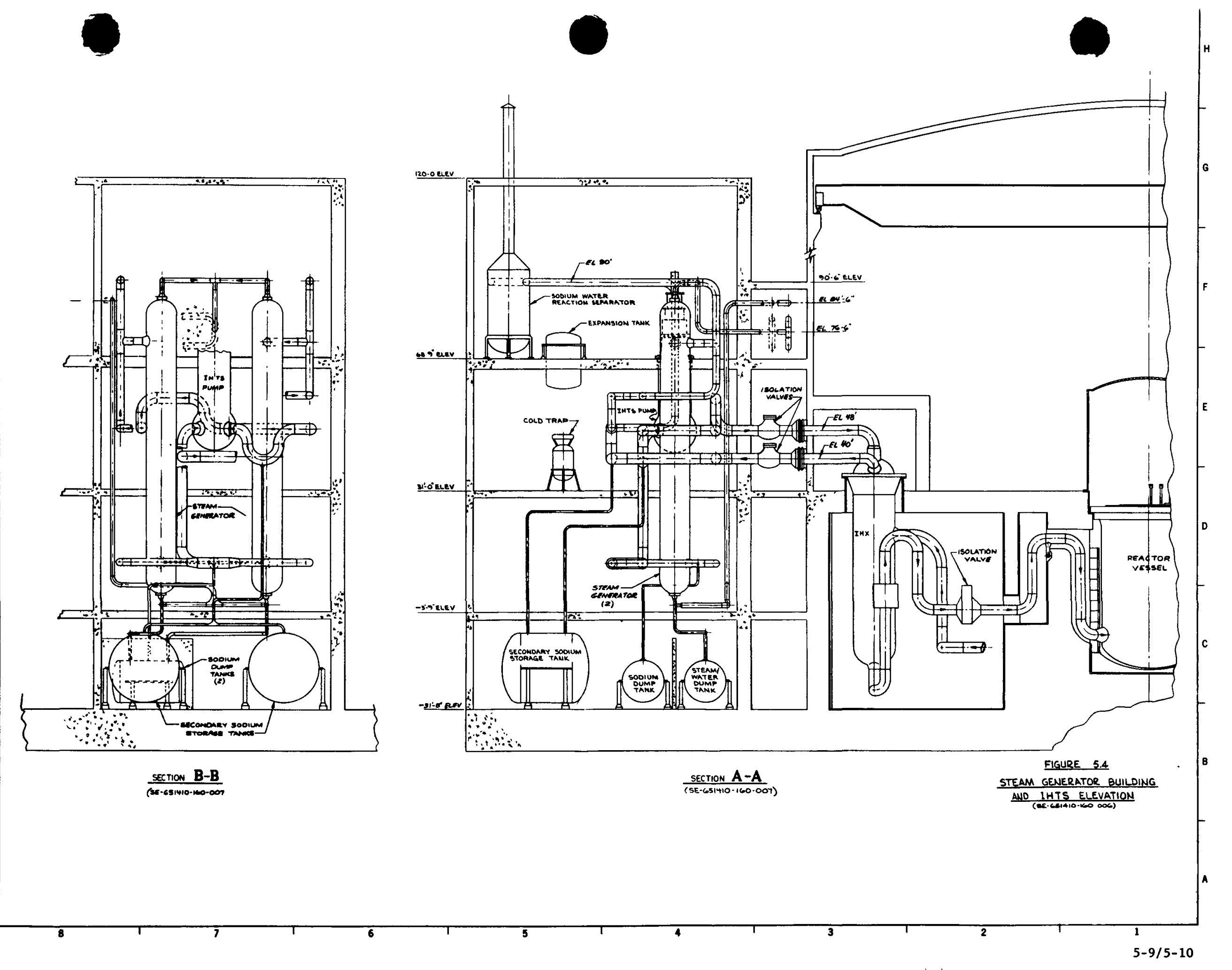




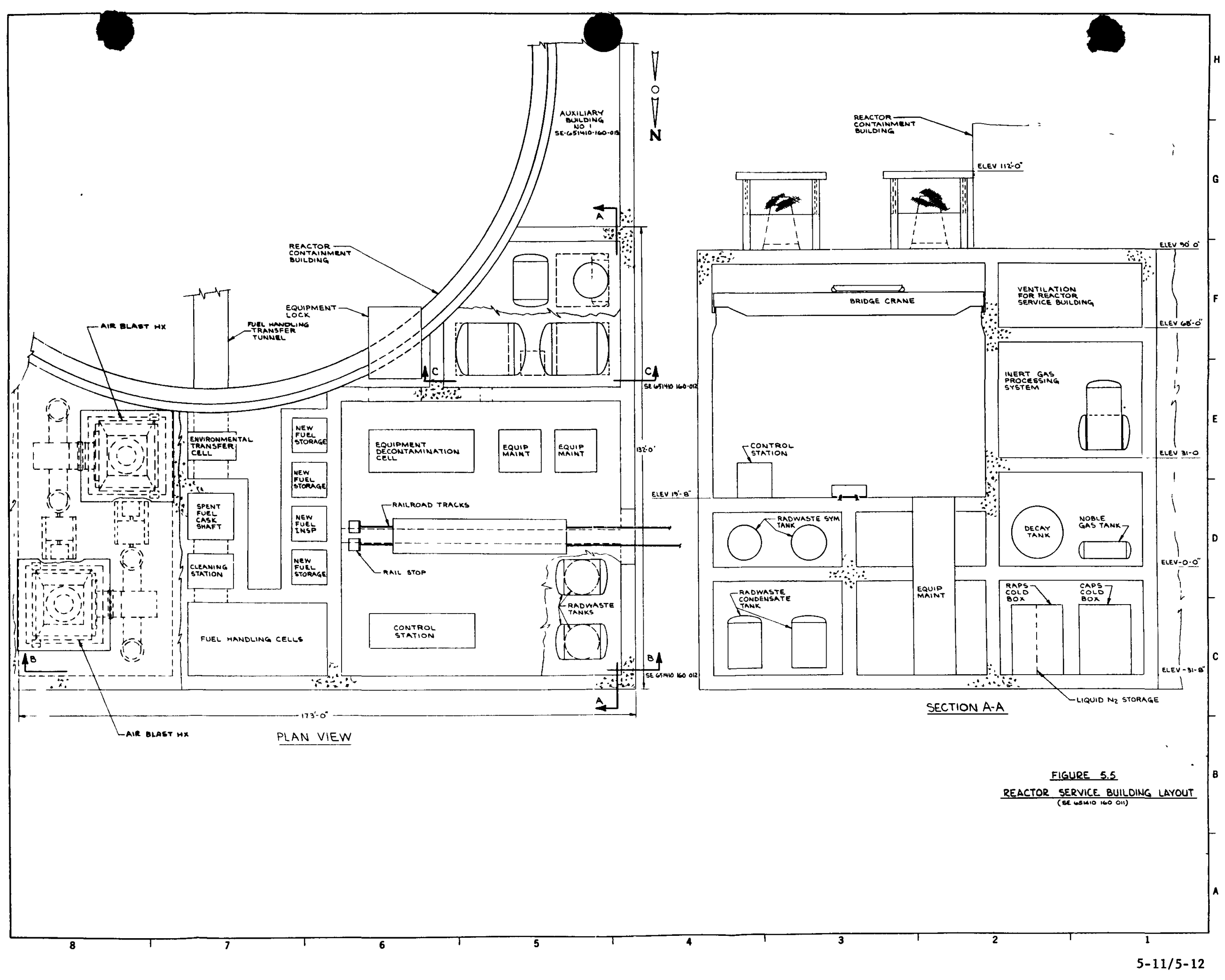



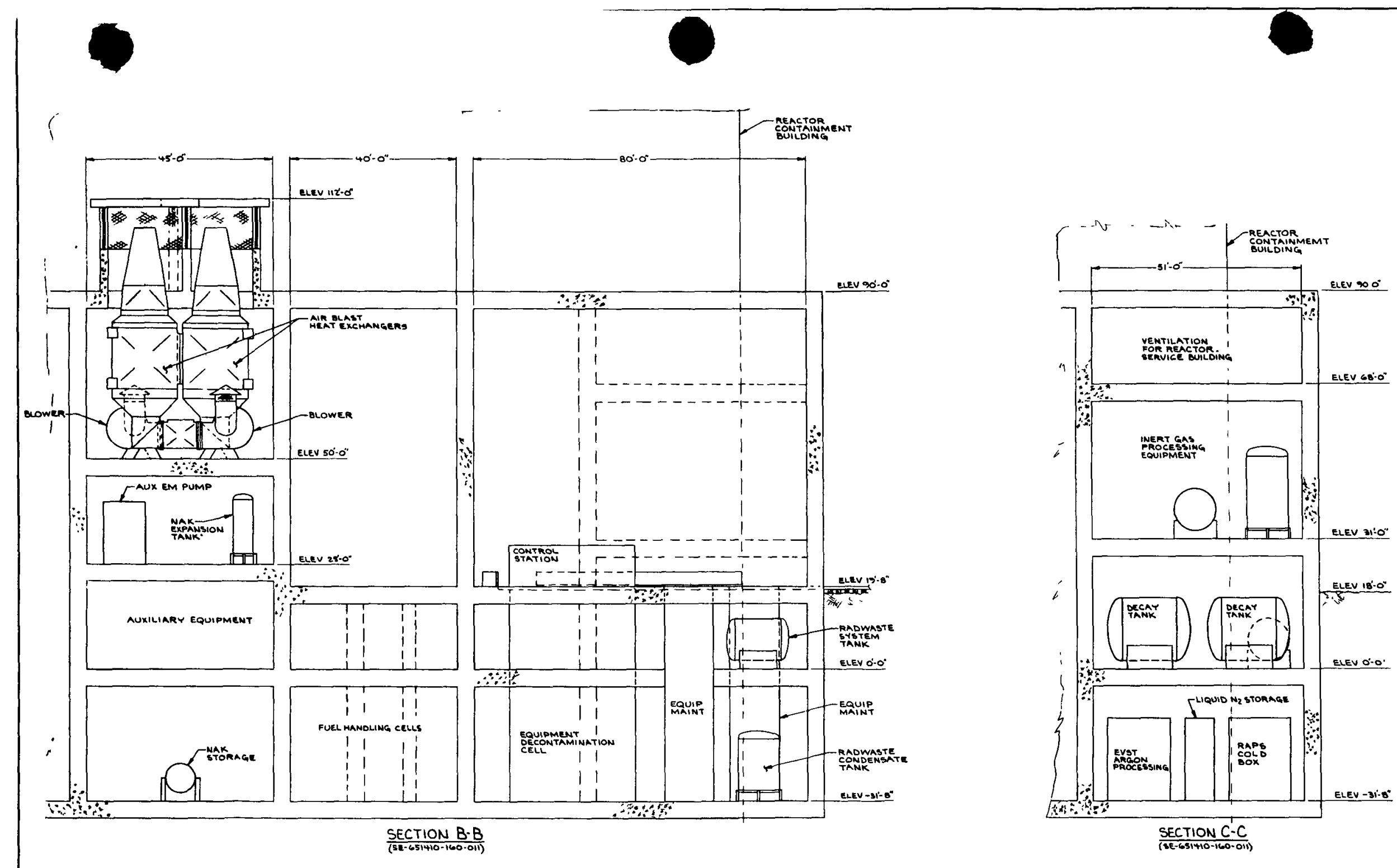

FIGURE 5.6

REACTOR SERVICE BUILDING SECTIONAL

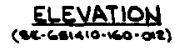




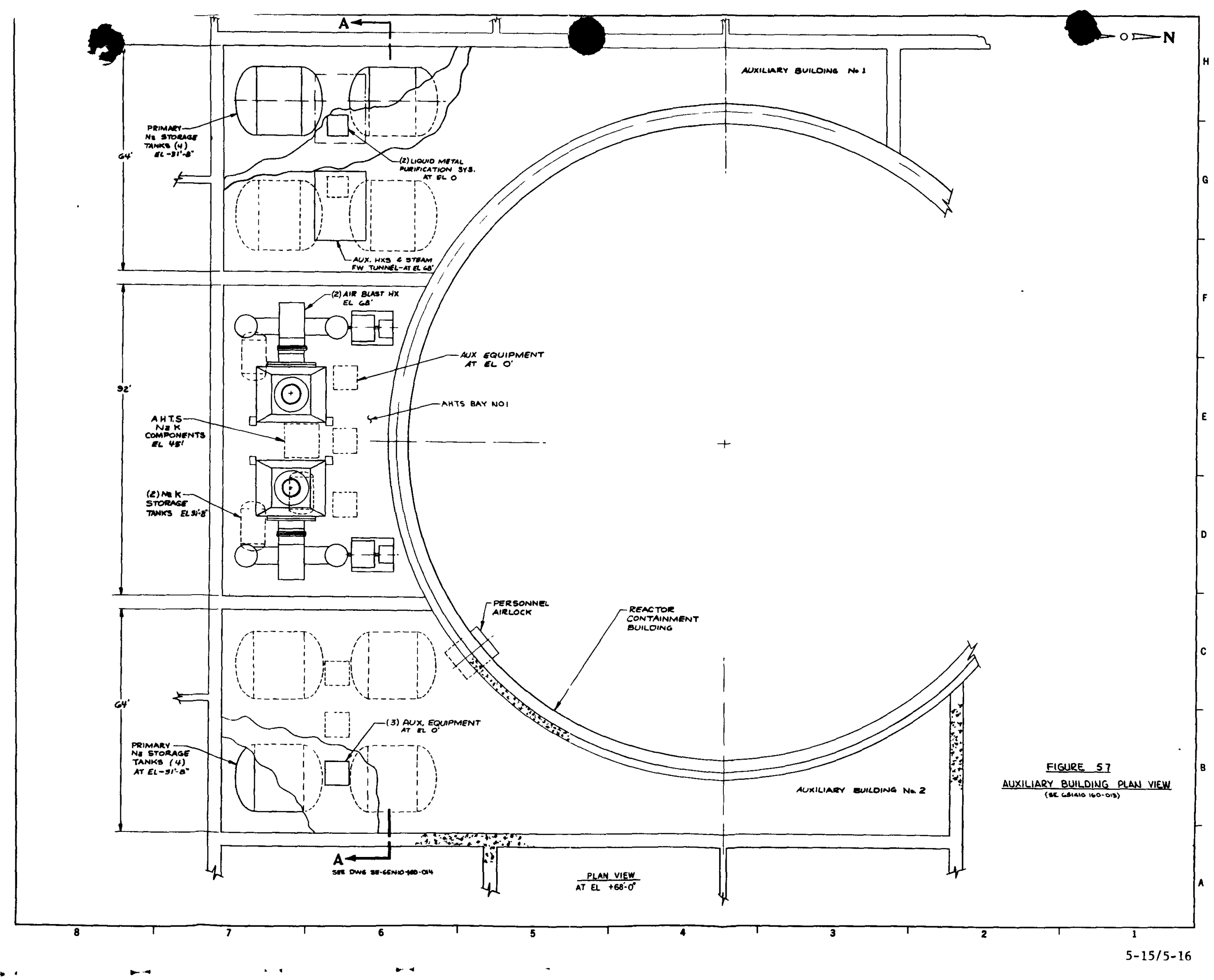




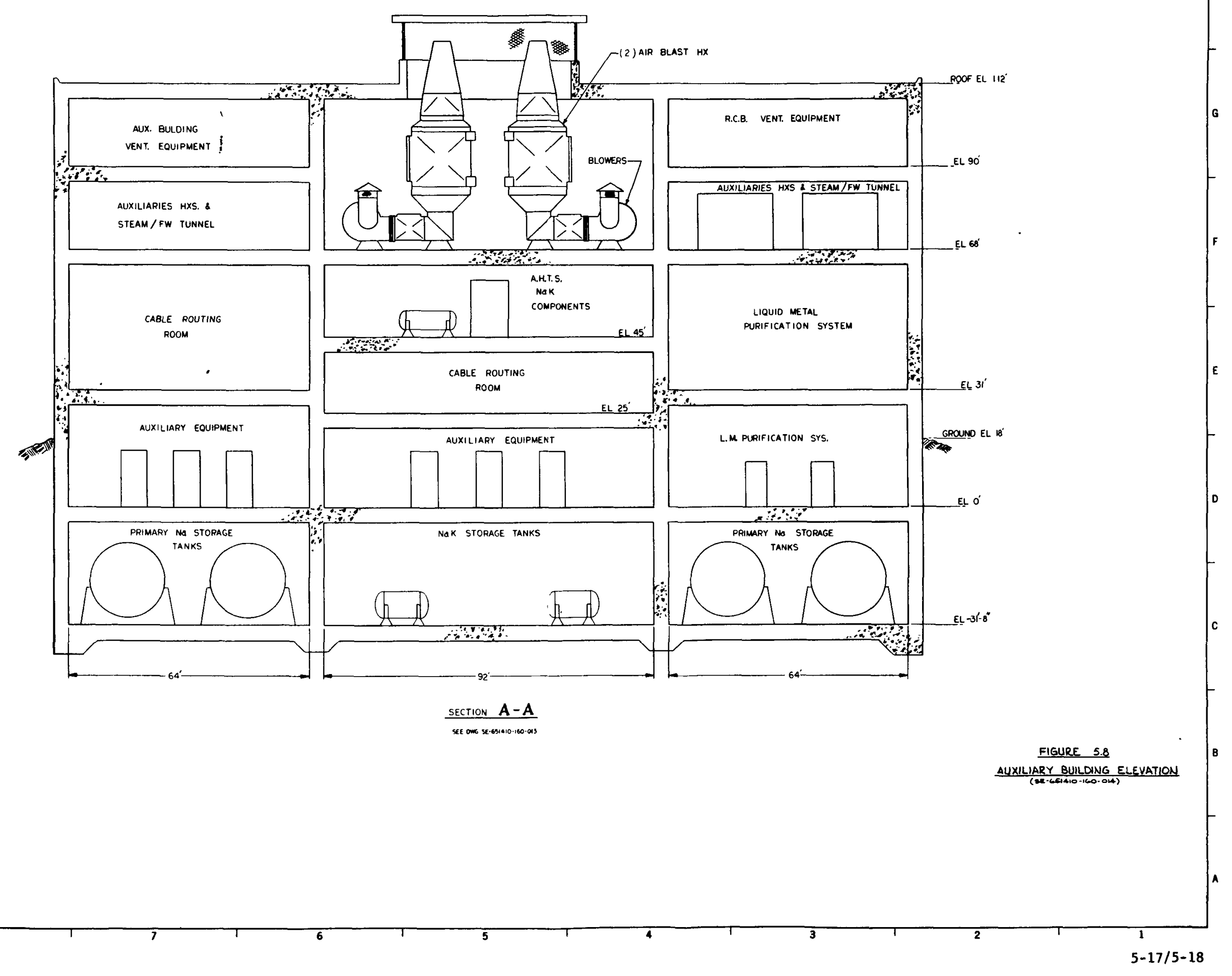




\section{EQUIPMENT LIST}

This section describes, in detail, the major components of the LMFBR Target Plant design developed by $\mathrm{C}-\mathrm{E}$ for this study. Each of component is described in terms of quantity, type, orientation, capacity, design pressure, design temperature, etc., in sufficient detail to permit preparation of the cost estimates given in section 3 of this report. The components are listed in accordance with an expanded AEC code-of-accounts (USAEC Report NUS-531), in the following Table 6.1 which permits correlation and cross referencing with the detailed cost estimates. 


\section{DESCRIPTION}

Number of Components per Plant

Design and Operating Conditions

Design Pressure/Temperature (Inlet Plenum)

Design Pressure/Temperature (Outlet Plenum)

Flow Rate

Fluid

Inlet Temperature/Outlet Temperature

Heat Load

Safety $\mathrm{Cl}$ ass

Physical Size and Weight

Maximum Diameter (She11)

Overall Length

Dry Weight

Materials

She11

Flange

Shell to Flange Transition

Thermal Liner

\section{COMPONENT SHELLS}

Shell Plate Thicknesses

Upper Cylindrical Region

Lower Cylindrical Region

Lower Head

Internal Cladding

Location

Material/Thickness

Nozzles

Inlet - Quantity/I.D.

Outlet - Quantity/I.D.

other - Quantity
LMFBR

TARGET PLANT

1

165 Psia $/ 675^{0} \mathrm{~F}$

$40 \mathrm{Psia} / 975 \mathrm{~F}$

$143.2 \times 10^{6} \mathrm{Tbm} / \mathrm{hr}$

$\mathrm{Na}$

$650^{0} \mathrm{~F} / 950^{0} \mathrm{~F}$

3800 MWt

Section III Class I

$27^{\prime}-5.00^{\prime \prime}$

$49^{\prime}-1.19^{\prime \prime}$

924,900 lbs.

SA-240, Type 304

SA $-508, C 1.3$

SB-168

SA-240, Type 304 $3.50^{\prime \prime}$

$2.50^{\prime \prime}$

2.50"

None

None
$4 / 35.00^{\prime \prime}$

$4 / 43.00^{\prime \prime}$

20 


\begin{tabular}{lc} 
& \multicolumn{1}{c}{ LESCRIPTION } \\
Penetrations in Lower Head - Quantity & TARGET PLANT \\
Linear Feet of Welds & None \\
Upper Flange & $1085 \mathrm{ft}$. \\
Inside Diameter & \\
Outside Diameter & $324.00^{\prime \prime}$ \\
Height & $367.00^{\prime \prime}$ \\
THERMAL LINER & $38.00^{\prime \prime}$ \\
\hline $\begin{array}{l}\text { Outside Diameter } \\
\text { Thickness } \\
\text { Length }\end{array}$ & \\
\hline
\end{tabular}

\section{SUPPORT SYSTEM}

Flange

Outside Diameter

$404.00^{\prime \prime}$

Height

$12.00^{\prime \prime}$

Skirt

Thickness

$6.00^{\prime \prime}$

Height

\section{CONSTITUENT WEIGHTS}

Weight of Shell

Shell Plate

Nozzles

Weld Metal

Upper Flange

Total Weight of Shell

525,600 1bs.

17,300 1bs.

18,700 lbs.

153,900 lbs.

Weight of Support Skirt and Flange

Flange Weight

Skirt Weight

Total Support Skirt and Flange Weight

68,300 lbs.

41,500 lbs.

109,800 1bs.

Weight of Thermal Liner

Total Weight of Thermal Liner

69,300 1bs.

Weight of Miscellaneous Items

Total Weight of Miscellaneous Items

$30,3001 \mathrm{bs}$. 


\section{DESCRIPTION}

Number of Components per Loop

Component Type or Configuration

Design and Operating Conditions

Design Pressure/Temperature (Structure)

Design Pressure/Temperature (Insulation)

Safety Class

Physical Sizes and Weights

Flange Outside Diameter

Flange Inside Diameter

Flange Height

Head Radius (Inner)

Head Thickness

Large Rotating Plug Diameter

Intermediate Rotating PTug Diameter

Small Rotating Plug Diameter

Thickness of Biological Shielding

Overall Height

Total Weight

Material

Flange

Head

Biological Shielding

Thermal Shielding

Seals

Quantity

Type

Material

Number of Control Rod Penetrations

Number of Bearings, Drives, and Controls
LMFBR

TARGET PLANT

1

Flat W/3 Rotating Plugs

$40 \mathrm{Psia} / 200^{\circ} \mathrm{F}$
$40 \mathrm{Psia} / 975^{\circ} \mathrm{F}$

Section III Class 1

$28^{\prime}-0.00^{\prime \prime}$

$22^{\prime}-6.00^{\prime \prime}$

$24.00^{\prime \prime}$

Flat

$24.00^{\prime \prime}$

$279.00^{\prime \prime}$

$228.50^{\prime \prime}$

$106.00^{\prime \prime}$

$30.00^{\prime \prime}$

$120.00^{\prime \prime}$

$1,380,000$ 1bs.

SA-508, Class 3

SA-508, Class 3

Graphite

SA-240, Type 304

3 Sets

Inflatable and Dip Seals

Silicon Rubber and Liquid Met.

61

3 
TABLE 6.1 (Continued)

DESCRIPTION

\author{
LMFBR \\ TARGET PLANT
}

3

Roller

279", 228", 106"

6

Reduction Gears

Servo Control 
TABLE 6.1 (Continued)

220A.2113 CAVITY FILLER SYSTEM

DESCRIPTION

Graphite Blocks

Quantity

Material

Size

Weight

Support System

Quantity

Type

Lift System

Quantity

Type
LMFBR

TARGET PLANT

236

Graphite Clad with Steel Plate $3^{\prime} \times 3^{\prime} \times 3^{\prime}$ (Approximately) 860,000 lbs (Tota1)

30

Screw Shafts Supported on Thrust Bearings

1

Motor/Gear Straight Pull

Rails for Transport 


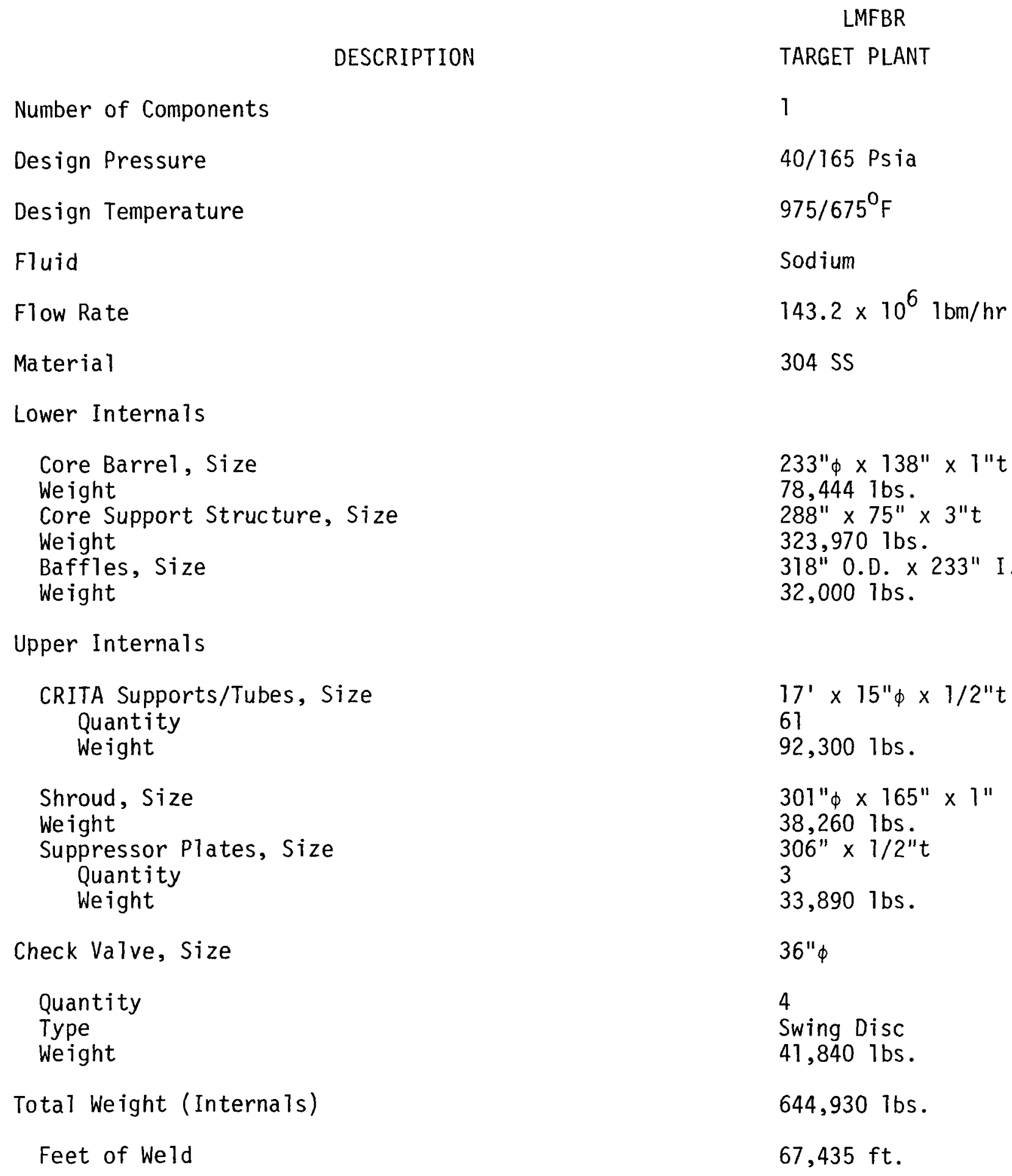


TABLE 6.1 (Continued)

\section{DESCRIPTION}

\section{CRITA \\ Quantity \\ Type \\ Size}

CONTROL ROD DRIVES

\section{LMFBR \\ TARGET PLANT}

61

Telescoping

$20^{\prime} \times 15^{\prime \prime} \phi$

30

Telescoping Servo Drive $30^{\prime} \times 12^{\prime \prime} \phi$

Pneumatic

48 " 
TABLE 6.1 (Continued)

220A.2211 PRIMARY PUMP AND MOTOR AND CONTROL

\begin{tabular}{|c|c|}
\hline & LMFBR \\
\hline DESCRIPTION & TARGET PLANT \\
\hline Quantity & 4 \\
\hline Design Pressure/Temperature & $165 \mathrm{Psia} / 950^{\circ} \mathrm{F}$ \\
\hline Type & Centrifugal/Single Stage \\
\hline Orientation & Vertical \\
\hline Flow Rate & $35.8 \times 10^{6} \mathrm{lbs} / \mathrm{hr}$ \\
\hline Speed & $690 \mathrm{rpm}$ \\
\hline TDH & $363 \mathrm{ft}$ \\
\hline BHP & $9000 \mathrm{HP}$ \\
\hline NPSH & $30 \mathrm{ft}$ \\
\hline Efficiency & $80 \%$ \\
\hline Material & SS \\
\hline Safety Class & $I$ \\
\hline Pump Casing & $304 S S$ \\
\hline $\begin{array}{l}\text { Diameter } \\
\text { Length } \\
\text { Weight }\end{array}$ & $\begin{array}{l}12^{\prime} \\
27^{\prime} \\
149,000 \text { 1bs. }\end{array}$ \\
\hline Pump Shaft & $304 S S$ \\
\hline $\begin{array}{l}\text { Diameter } \\
\text { Length } \\
\text { Weight }\end{array}$ & $\begin{array}{l}12^{\prime \prime} \\
20^{\prime}-8^{\prime \prime} \\
12,000 \text { 1bs. }\end{array}$ \\
\hline Impeller & $304 S S$ \\
\hline $\begin{array}{l}\text { Diameter } \\
\text { Weight }\end{array}$ & $\begin{array}{l}68 " \\
8000 \mathrm{lbs} .\end{array}$ \\
\hline \multicolumn{2}{|l|}{ Bearings } \\
\hline $\begin{array}{l}\text { Number } \\
\text { Type }\end{array}$ & ${ }_{\text {Hydrostatic }}$ \\
\hline
\end{tabular}


TABLE 6.1 (Continued)

DESCRIPTION

Shielding
Weight
Pump Supports
Type
Weight
Motors
Type
Rating
Speed Control
Type
Rating
Total Weight (Pump Only)

\section{LMFBR \\ TARGET PLANT}

Shots

Flange Mounted (Fixed)

Induction $A C$ $9000 \mathrm{HP}$

Motor/Generator $9000 \mathrm{HP}$

$302,0001 \mathrm{bs}$. 


\section{DESCRIPTION}

Design Temperature (Hot Leg)

Design Temperature (Cold Leg)

Design Pressure (HP)

Design Pressure (LP)

Safety Class

Material

Large Piping
Size

Length

El bows

Flow

Size

Length

El bows

Medium Piping

Diameter

Length

Sma11 Piping

Diameter

Length
LMFBR

TARGET PLANT

$975^{\circ} \mathrm{F}$

$675^{\circ} \mathrm{F}$

165 Psia

40 Psia

I

$316 S S / 304 S S$

44" O.D. $\times 5 / 8 " t$ $754^{\prime}$

36

$35.8 \times 10^{6} \mathrm{lbs} / \mathrm{hr}$

$36^{\prime \prime}$ O.D. $\times 1 / 2^{\prime \prime} \mathrm{t}$ $1348^{\prime}$

64

LP, Siphon, Overflow

$8 "-14$ " Schedule 40 $628^{\prime}$

Drain and Vent

6" and Smaller Schedule 40 $736^{\prime}$ 


\section{DESCRIPTION}

LMFBR

\section{TARGET PLANT}

Hot Leg Isolation Valves

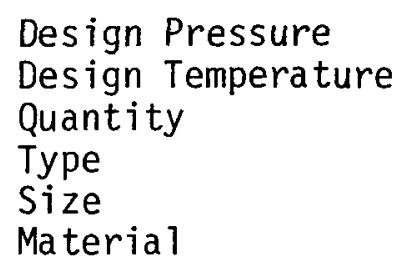

50 psia

$975^{\circ} \mathrm{F}$

4

Disc/Wedge $44 " \phi$ $304 S S$

Cold Leg Isolation Valves

Design Pressure
Design Temperature
Quantity
Type
Size
Material

Throttle/Check Valves

$$
\begin{aligned}
& \text { Quantity } \\
& \text { Type } \\
& \text { Size } \\
& \text { Material }
\end{aligned}
$$

Drain Valves

Quantity
Type
Size

Siphon Breaker Diodes

$$
\begin{aligned}
& \text { Quantity } \\
& \text { Type } \\
& \text { Size }
\end{aligned}
$$

IHX Vent Line Orifices

$$
\begin{aligned}
& \text { Quantity } \\
& \text { Type } \\
& \text { Size }
\end{aligned}
$$

22

165 Psia
$675^{\circ} \mathrm{F}$
4
Wedge
$36 " \phi$
$304 S S$

4 Need le $14 "$ $304 S S$ Wedge/Disc 6"

4 Nozzles 8"

4 Orifice Plates 1" 


\section{A.2213 INTERMEDIATE HEAT EXCHANGER}

\section{DESCRIPTION}

Number of Components per Plant

Component Type or Configuration

Flow Characteristics

Orientation

She11 Size Design and Operating Conditions

Design Pressure/Design Temperature

Flow Rate

Fluid

Inlet Temperature/Outlet Temperature

Tube Side Design and Operating Conditions

Design Pressure/Design Temperature

Flow Rate

Fluid

Inlet Temperature/Outlet Temperature

Net Load Per Component

Safety Class

Physical Size and Weight

Maximum Diameter (Shel1)

Overall Length

Dry Weight - Per Component/Per Plant

Materials

Shell Plate

Tubesheets

Tubes

\section{COMPONENT SHELL}

Shell Plate Thicknesses

Cylindrical Shell Region

Upper Hemispherical Head

Lower Hemispherical Head (Inner)

Lower Hemispherical Head (Outer)
LMFBR

TARGET PLANT

4

St. Tube/St. Shell

Counterflow

Vertical

165 Psia $/ 975^{\circ} \mathrm{F}$

$35.8 \times 10^{6} 1 \mathrm{bm} / \mathrm{hr}$

$\mathrm{Na}$

$950^{\circ} \mathrm{F} / 650^{\circ} \mathrm{F}$

165 Psia $/ 975^{\circ} \mathrm{F}$

$33.4 \times 10^{6} \mathrm{lbm} / \mathrm{hr}$

$\mathrm{Na}$

$590^{\circ} \mathrm{F} / 910^{\circ} \mathrm{F}$

950 MWt

Section III Class I

$12^{\prime}-3.19^{\prime \prime}$

$64^{\prime}-1.00^{\prime \prime}$

$639,400 / 2,557,600$ ibs

SA-240, Type 304

SA-182, Type 304

SA-213, Type 304 $3.00^{\prime \prime}$

$3.00^{\prime \prime}$

$3.00^{\prime \prime}$

$3.00^{\prime \prime}$ 


\section{DESCRIPTION}

Nozzles

Shell Side Inlet - Quantity/I.D.

Shell Side Outlet - Quantity/I.D.

Tube Side Inlet - Quantity/I.D.

Tube Side Outlet - Quantity/I.D.

Lineal Feet of Welds

COMPONENT TUBE BUNDLE

Number of Tubes - Per Component/Per Plant

Mean Heated Length

Tube Side - 0.D./Wa11 Thickness/Pitch

Heat Transfer Area - Per Component/Per Plant

Tube Support Concept

Type of Tube to Tubesheet Weld

Tube Bundle Shroud (Outer)

Inside Diameter

Thickness

Length

Tube Bundle Shroud (Inner)

Inside Diameter

Thickness

Length

Downcomer

Inside Diameter

Thickness

Length

Upper Thermal Liner

Inside Diameter

Thickness

Length

\section{COMPONENT TUBESHEETS}

Number Per Component

Finished Diameter - Upper/Lower

Finished Thickness - Upper/Lower
LMFBR

TARGET PLANT

$1 / 35.00^{\prime \prime}$

$1 / 35.00^{\prime \prime}$

$1 / 35.00^{\prime \prime}$

$1 / 35.00^{\prime \prime}$

$510 \mathrm{ft}$.

$3,846 / 15,384$

$45^{\prime}-0.00^{\prime \prime}$

$1.25^{\prime \prime} / 0.045^{\prime \prime} / 1.697^{\prime \prime}$

$56,600 \mathrm{ft} .2 / 226,400 \mathrm{ft}{ }^{2}$

Eggcrates $w /$ baffles

Rolled and Seal Welded

$123.19^{\prime \prime}$

$1.00 "$

$41^{\prime}-3.5^{\prime \prime}$

$39.25^{\prime \prime}$

$0.63^{\prime \prime}$

$37^{\prime}-7.0^{\prime \prime}$

$36.00^{\prime \prime}$

$0.63^{\prime \prime}$

$57^{\prime}-0.0^{\prime}$

$34.50^{\prime \prime}$

$0.50^{\prime \prime}$

$9^{\prime}-2.0^{\prime \prime}$
2

$133.12 " / 133.12^{\prime \prime}$

$12.00 " / 12.00^{\prime \prime}$ 


\section{DESCRIPTION}

LMFBR

TARGET PLANT

\section{CONSTITUENT WEIGHTS}

Weight of Shel1 (Pressure Boundary)

Plate Material

297,300 1bs.

Nozzles

Weld Metal

Total Weight of Shell

10,100 lbs.

7,800 lbs.

315,200 lbs.

Weight of Tube Bundle

Tubing

Tube Supports and Baffles

$107,2007 \mathrm{bs}$

Shrouds

15,400 1bs.

Downcomer

67,100 lbs.

Total Weight of Tube Bundle

12,900 1bs.

202,600 lbs.

Weight of Tubesheets

Upper Tubesheet

27,900 1bs.

Lower Tubesheet

Total Weight of Tubesheets

29,800 1bs.

57,700 lbs.

Weight of Miscellaneous Items

Total Weight of Miscellaneous Items

$63,9001 \mathrm{bs}$. 
TABLE 6.1 (Continued)

220A.2221 SECONDARY PUMP AND MOTOR AND CONTROL

LMFBR

DESCRIPTION

TARGET PLANT

\begin{tabular}{|c|c|}
\hline Pump & \\
\hline $\begin{array}{l}\text { Quantity } \\
\text { Design Pressure/Temperature } \\
\text { Type } \\
\text { Orientation } \\
\text { Flow Rate } \\
\text { Speed } \\
\text { TDH } \\
\text { BHP } \\
\text { NPSH } \\
\text { Efficiency } \\
\text { Material } \\
\text { Safety Class }\end{array}$ & $\begin{array}{l}4 \\
300 \text { Psia/ } 625^{\circ} \mathrm{F} \\
\text { Centrifugal } \\
\text { Vertical } \\
33.4 \times 10^{6} \mathrm{lbs} / \mathrm{hr} \\
700 \mathrm{rpm} \\
291 \mathrm{ft} \text {. } \\
6700 \mathrm{HP} \\
148 \mathrm{ft} . \\
85 \% \\
304 S S \\
\text { NNS }\end{array}$ \\
\hline Pump Casing & $304 S S$ \\
\hline $\begin{array}{l}\text { Diameter } \\
\text { Length } \\
\text { Weight }\end{array}$ & $\begin{array}{l}12 \mathrm{ft} . \\
21 \mathrm{ft} . \\
116,0001 \mathrm{bs} .\end{array}$ \\
\hline Pump Shaft & $3045 S$ \\
\hline $\begin{array}{l}\text { Diameter } \\
\text { Length } \\
\text { Weight }\end{array}$ & $\begin{array}{l}12^{\prime \prime} \\
15 \mathrm{ft} . \\
8,700 \text { ibs. }\end{array}$ \\
\hline Impeller & $304 S S$ \\
\hline $\begin{array}{l}\text { Diameter } \\
\text { Weight }\end{array}$ & $\begin{array}{l}68 " \\
8,0001 \mathrm{bs} .\end{array}$ \\
\hline Bearings & $3045 S$ \\
\hline $\begin{array}{l}\text { Number } \\
\text { Type }\end{array}$ & 2 \\
\hline $\begin{array}{c}\text { Shielding } \\
\text { Weight }\end{array}$ & Not Required \\
\hline Pump Supports & \\
\hline $\begin{array}{l}\text { Type } \\
\text { Weight }\end{array}$ & Flange, Fixed \\
\hline
\end{tabular}




\section{DESCRIPTION}

Motors

Type

Rating

Speed Control

Type

Rate

Total Weight (Pump Only)
LMFBR

TARGET PLANT

AC-Induction

$7000 \mathrm{HP}$

Motor/Generator

7000 HP

284,000 1bs. 
TABLE 6.1 (Continued)

\section{A. 22221 SECONDARY PIPING}

\section{DESCRIPTION}

\section{Safety Class}

Design Pressure

Design Temperature (Hot/Cold)

Material

Large Piping
Diameter
Length
Elbows
Diameter
Length
Elbows

\section{Sma 11 Piping}

Diameter

Length

\section{LMFBR}

TARGET PLANT

NNS

300 Psia

$950 / 625^{\circ} \mathrm{F}$

304SS

$36 "$ O.D. $\times 1 / 2^{\prime \prime} t$ $1600^{\prime}$

72

$26 "$ 0.D. $\times 1 / 2^{\prime \prime} t$

$1520^{\prime}$

68

6" and Smaller, Schedule 40 $2088^{\prime}$ 
TABLE 6.1 (Continued)

220A.22222 SECONDARY VALVES

DESCRIPTION

Design Pressure

Design Temperature

Materia 1

Safety Class

Large Valves

Quantity

Size

Type

Small Valves

Quantity

Size

Type
LMFBR

TARGET PLANT

300 Psia

$950 / 625^{\circ} \mathrm{F}$

$304 S S$

NNS

8

$36^{\prime \prime}$

Isolation

56

6" and Smaller

Isolation 
TABLE 6.1 (Continued)

220A.2224 SECONDARY EXPANSION TANK

DESCRIPTION

LMFBR

TARGET PLANT

Number of Components per Plant

4

Design and Operation Conditions

Design Pressure/Temperature

Fluid

300 Psia $/ 600^{\circ} \mathrm{F}$

$\mathrm{Na}$

Heat Input Capacity

None

Safety $\mathrm{Class}$

NNS

Physical Size and Height

Maximum Diameter (Shel1)

$123.26^{\prime \prime}$

Overall Length

Dry Weight

$15^{\prime}-11.63^{\prime \prime}$

47,900 ibs.

Material

Shell Plate

Support Skirt

Support Flange

$3045 S$

None

30455

\section{COMPONENT SHELLS}

Shell Plate Thicknesses

Cylindrical Shell Region

$1.63^{\prime \prime}$

Upper and Lower Heads

$1.63^{\prime \prime}$

Internal $\mathrm{Cladding}$

Location

Material/Thickness

None

None

Nozzles and Manways

Total Number

Range of Inside Diameters

Manway - Quantity/Size

Heater Penetrations - Quantity

Instrument Nozzles - Quantity

6

2.00" thru 4.00"

$1 / 16.00^{\prime \prime}$

None

None

Lineal Feet of Welds

$135 \mathrm{ft}$. 


\title{
TABLE 6.1 (Continued)
}

\section{DESCRIPTION}

LMFBR

TARGET PLANT

\section{CONSTITUENT WEIGHTS}

\author{
Weight of Shell \\ Shell Plate \\ Nozzles and Manways \\ Weld Metal \\ Support Skirt \\ Support Flange \\ Total Weight of Shell \\ Weight of Miscellaneous Parts \\ Total Weight of Miscellaneous Parts
}

35,300 ibs.

$850 \mathrm{Tbs}$.

650 ibs.

None

11,000 1bs.

47,800 lbs.

$100 \mathrm{lbs}$. 


\section{DESCRIPTION}

Number of Components Per Plant

Component Type or Configuration

Flow Characteristics

Orientation

Shell Side Design and Operating Conditions

Design Pressure/Design Temperature

Flow Rate

Fluid

In let Temperature/0uter Temperature

Tubeside Design and Operating Conditions

Design Pressure/Design Temperature

Flow Rate

Fluid

Inlet Temperature/Outlet Temperature

Heat Load Per Component

Safety Class

Physical Size and Weight

Maximum Diameter (She11)

Overall Length

Dry Weight - Per Component/Per Plant

Materials

Shell Plate

Tubesheet(s)

Tubes

\section{COMPONENT SHELLS}

Shell Plate Thicknesses

Upper Cylindrical Shell Region Conical Transition Shell Course Lower Cylindrical Shell Region Steam Outlet Hemispherical Head Upper Sodium Hemispherical Head Lower Hemispherical Head
LMFBR

TARGET PLANT

8

St. Tube/St. Tube

Counterflow

Vertical

300 Psia $/ 935^{\circ} \mathrm{F}$

$16.70 \times 10^{6} \mathrm{bm} / \mathrm{hr}$

$\mathrm{Na}$

$910^{\circ} \mathrm{F} / 590^{\circ} \mathrm{F}$

2275 Psia $6875^{\circ} \mathrm{F}$

$1.78 \times 10^{6} \mathrm{lbm} / \mathrm{hr}$

${ }_{4}{ }^{\mathrm{O}} 0^{\circ} \mathrm{F} / 854^{\circ} \mathrm{F}$

475 MWT

NNS-ASME Section VIII

$106.75^{\prime \prime}$

$88^{\prime}-8.0^{\prime \prime}$

$648,000 / 5,184,0001$ bs.

$2-1 / 2 \mathrm{Cr}-7 \mathrm{Mo}$

SA-387, GR. 22, CL. 1

SA-336 F22

SA-213, GR. T22 $2.50^{\prime \prime}$

None

$1.50^{\prime \prime}$

$5.50^{\prime \prime}$

$1.50^{\prime \prime}$

$5.00^{\prime \prime}$ 
DESCRIPTION

Internal Cladding

Location

Material/Thickness

Nozzles

Shel1 Side Inlet - Quantity/I.D.

Shel1 Side Outlet - Quantity/I.D.

Tube Side Inlet - Quantity/I.D.

Tube Side Outlet - Quantity/I.D.

Access Ports or Manways - Quantity/I.D.

Lineal Feet of Welds

\section{TUBE BUNDLES}

Number of Tubes - Per Component/Per Plant

Mean Heated Length

Tube Size - 0.D./Wall Thickness/Pitch

Heat Transfer Area - Per Component/Per Plant

Tube Support Concept

Type of Tube-to-Tubesheet Weld

Tube Bundle Shroud

Inside Diameter

Thickness

Length

TUBE SHEETS

Number Per Component

Finished Diameter - Upper/Lower

Finished Thickness - Upper/Lower

Clad Material/Clad Thickness

CONSTITUENT WEIGHTS

Weight of Shell (Pressure Boundary)

Plate Material

Nozzles, Access Ports, Manways, Etc.
LMFBR

TARGET PLANT

None

None

$1 / 25.00^{\prime \prime}$

$1 / 25.00^{\prime \prime}$

$1 / 18.00^{\prime \prime}$

$1 / 18.00^{\prime \prime}$

$2 / 24.00^{\prime \prime}$

$310 \mathrm{ft}$.

$3,547 / 28,376$

$72^{\prime}-0^{\prime \prime}$

$0.75^{\prime \prime} / 0.735^{\prime \prime} / 1.250^{\prime \prime}$

$50,145 \mathrm{Ft}^{2} / 401,160 \mathrm{Ft}^{2}$ Drilled Plates

Face and Back Side

$80.88^{\prime \prime}$

$1.00^{\prime \prime}$

$67^{\prime}-6.00^{\prime \prime}$

2

$101.00 " / 101.00 "$

$26.00^{\prime \prime} / 23.00^{\prime \prime}$

None/None

161,000 1bs.

18,300 1bs. 


\section{DESCRIPTION}

Weight of Weld Metal

Total Weight of Shell

Weight of Tube Bundle

Tubing

Tube Supports

Shrouds

Total Weight of Tube Bundle

Weight of Tubesheets

Upper

Lower

Total Weight of Tubesheets

Weight of Steam Separation Equipment

Weight of Separators

Weight of Dryers

Weight of Supports

Total Weight of Steam Separator Equipment

Miscellaneous Parts

Total Weight of Miscellaneous Parts
LMFBR

TARGET PLANT

2,400 1bs. 181,700 1bs.

$226,7001 \mathrm{bs}$. 30,300 lbs. 66,100 1bs. 323,100 1bs.

49, 100 1bs. 36,600 1bs. 82,700 Tbs.

None

None

None

None

$60,5001 \mathrm{bs}$. 
TABLE 6.1 (Continued)

$220 \mathrm{~A} .2233 \mathrm{Na} / \mathrm{H}_{2} 0$ REACTION PROTECTION

DESCRIPTION

LMFBR

TARGET PLANT

16

$304 S S$

4

$12^{\prime}$

24 '

70,000 gallons

$3045 S$

87,000 Tbs

Steam Water Dump Tanks (4)

Sodium Dump Tanks (4)

Quantity

8

Diameter

Length

Volume

Material

Weight

Large Piping

Diameter

Length

Material

764

$764^{\prime}$

Carbon Steel

Small Piping

Diameter

Length

Material

6" and Smaller

1292'

Carbon Stee1

Valves

Quantity

Type

Size

36

Gate

$6 "$ and Smaller - 20

$10 "$ - 8

$26 "-8$ 
TABLE 6.1 (Continued)

\section{A.231 SAFEGUARDS SYSTEM}

LMFBR

DESCRIPTION

TARGET PLANT

Decay Heat Removal Pumps

Quantity

Type

Fluid

Flow

Head

Design Pressure/Design Temperature

Safety Class

Materials

Rating

Quantity

Type

Fluid

Flow

Head

Design Pressure/Design Temperature Safety Class

Material

Rating

2

EM

$\mathrm{Na}$

5200 GPM

$140 \mathrm{ft}$.

100 Psia/ $/ 970^{\circ} \mathrm{F}$

2

$3045 S$

$540 \mathrm{HP}$

2

EM

NaK

7086 GPM

$67 \mathrm{ft}$.

$200 \mathrm{Psia} / 650^{\circ} \mathrm{F}$

2

304 SS

352 HP

AHTS Fans

Quantity

Type

Flow

Rating

AHTS Heat Exchangers

Quantity

Type

Fluid

Safety Class

Flow

Design Pressure

Design Temperature

Thermal Rating

Material

$\mathrm{Ht}$. Area, Ft. ${ }^{2}$
4

Centrifugal

$2.5 \times 10^{5}$ CFM

$1250 \mathrm{HP}$

2

She11/Tube

$\mathrm{Na} / \mathrm{NaK}$

1

$5200 / 7086$ GPM

$200 \mathrm{Psia}$

$1050^{\circ} \mathrm{F}$

$194 \times 10^{6} \mathrm{BTU} / \mathrm{HR}$

304SS

2,500 each 


\section{AHTS ABHX}

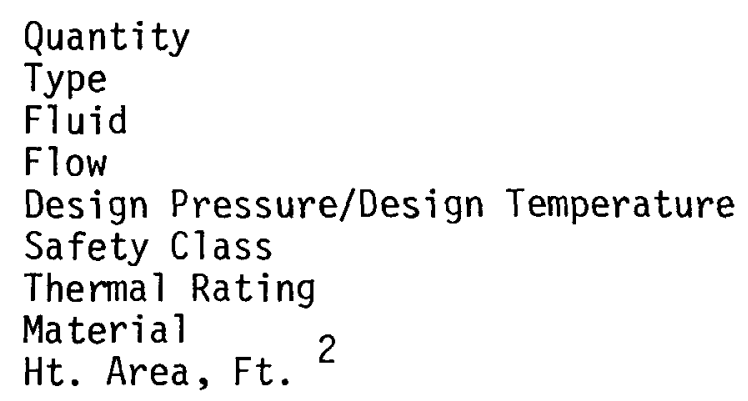

Piping

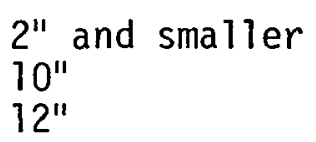

Valves

Quantity

Type

Size

\section{Tanks}

Quantity
Type
Fluid
Design Pressure
Design Temperature
Size
Volume
Material
Weight

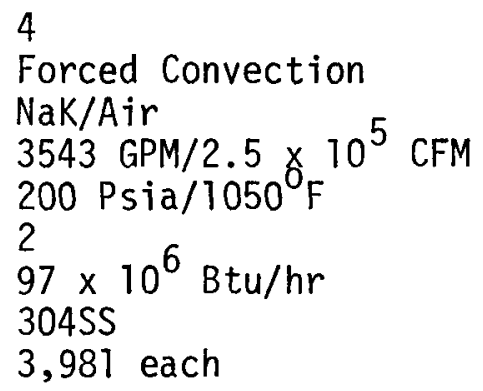

18

Isolation

$10^{\prime \prime}$ to 12 " 
TABLE 6.1 (Continued)

220A.25 REFUELING SYSTEMS - RECEIVING, STORAGE AND SHIPPING

DESCRIPTION

LMFBR

TARGET PLANT

New Fuel Handling Crane

Travel (ft.)

Hoist Capacity (ton)

Lift (ft.)

Classification

No. of Drives

Weight (1b.)

New Fuel Storage Racks

Dimensions

Capacity

Classification

Weight (1b.)
50 (Bridge), 30 (Trolley)

0.50

20 Approximately

3

4,000

6.25" FTF, 14' High

298 Fuel Assemblies

700 1bs. per cell 
LMFBR

\section{DESCRIPTION}

Number of Components per Plant

Design Pressure/Temperature

Fluid Contained

Safety Class

Physical Size and Weight (Assembled)

Maximum She11 Diameter

Overall Length

Total Weight

Materials for Tank

She11

Flange

Materials for Closure Head

Structural Cover

Materials for Turntables

Barre1

Grid Plates

Lower Support Structure

COMPONENT SHELL

Shell Plate Thicknesses

Upper Cylindrical Region

Lower Cylindrical Region

Lower Head

Nozzles

Total Number

Range of Inside Diameters
TARGET PLANT

1

Vertical

$\mathrm{Na}$

2

$19^{\prime}-9.38^{\prime \prime}$

$50^{\prime}-0^{\prime \prime}$

$1,213,000$ 1bs. *

SA-240, Type 304

$S A-508$, Class 2

SA-533, GR. B, CL. 1

SA-240, Type 304

SA-240, Type 304

SA-240 and 479, Type 304

* Does not include weight of drive mechanisms or storage tubes. 
CLOSURE HEAD

Structure Cover Thickness

$12.00^{\prime \prime}$

Thermal Shielding

Number of Plates

25

Thickness of Plates

Number of Penetrations

36

Type of Seals

Plated Double "C"

TURNTABLE

Barrel Thickness

$2.53^{\prime \prime}$

Grid Plate Thickness/Number

$6.25 / 2$

Number of Storage Positions 334

DRIVE MECHANISMS

Number of Bearings

2

Drive Motor Power

Drive Motor Control

CONST ITUENT WEIGHTS

Total Weight of Tank

420,000 ibs.

Total Weight of Closure Head 300,000 1bs.

Total Weight of Turntable 493,000 lbs.

Total Weight of Drive Mechanism

$\star \star \star$

** Unknown

$\star \star *$ Does not include the weight of storage tubes. 


\section{A.25 REFUELING SYSTEMS - EX-VESSEL HANDLING MECHANISMS}

LMFBR

DESCRIPTION

TARGET PLANT

EVHM Trolley Line

Track Length/Gauge

Load (tons)

Classification

Weight (1bs)

$75^{\prime} / 5^{\prime}$ Centers

16 on Rails

2,000

Spent Fuel Rails

Track Length ( $\mathrm{ft}$. )

50

Grapple Guide (ft.)

28

Load (tons)

37 on Rails

Classification

Weight (1bs.)

2,500

EVHM

Dimensions

Stroke ( $\mathrm{ft}$. )

Motors (number)

Drives (number)

Classification

Weight (tons)

$6^{\prime}-9^{\prime \prime} \times 12^{\prime}-0^{\prime \prime} \times 28^{\prime}-0^{\prime \prime}$ High

50 (Maximum)

4

6

16

Spent Fuel Cask Cart

Dimensions

Motors (number)

Drives (number)

Classification

Weight (1bs.)

$12^{\prime}-0^{\prime \prime} \times 12^{\prime}-0^{\prime \prime} \times 22^{\prime}-0^{\prime \prime}$ High

4

1 Cart, 1 Welder Head,

1 Welding Power Supply

24,000 (less cask) 
TABLE 6.1 (Continued)

\section{A.25 REFUELING SYSTEMS - TRANSFER MECHANISMS}

DESCRIPTION

LMFBR

TARGET PLANT

Transfer Arm and Motor

Dimensions

Arm and Structure 18' Long 12" x 18" Drive Package with 6' Drive Shaft

Swing

Classification

Weight (1bs.)

$31.75^{\prime \prime}$ with $8001 \mathrm{~b}$. 1oad

Refueling Elevator and Motor

Dimensions

Load (1bs.)

Lift (ft.)

Classification

Weight (1bs.)

3,250

Transfer Pots

Number

Dimensions

Classification

Weight (1b.)

$15^{\prime \prime} \times 36^{\prime \prime} \times 30^{\prime}$ long

1,250

12 (Approximately)

3,000 (no load)

300

10" O.D. $\times 13.5^{\prime}$ Tong

850 
TABLE 6.1 (Continued)

220A. 25 REFUELING SYSTEMS - IN-VESSEL HANDL ING MECHANISMS

DESCRIPTION

LMFBR

TARGET PLANT

IVHM

Dimensions

Lift (ft.)

Stroke (in.)

Drives (number)

Classification

Weight (1b.)
12" Diameter $\times 32$ ' long (lower)

$6^{\prime}-6^{\prime \prime}$ Square $\times 26^{\prime}$ long (upper)

27 for Removal

170

4

17,500 
TABLE 6.1 (Continued)

\section{A.25 REFUEL ING SYSTEM - FUEL HANDLING CELLS}

LMFBR

DESCRIPTION

TARGET PLANT

New Fuel Conveyor and Tubes

Track Length (ft.)

Load

Classification

Weight (7b.)

85 (Approximately)

8 Assemblies 0

400 1b. each

11 " long

7,000

Environmental Change

Cel1 Equipment

Hoist

Shuttle

Fuel Guide

Classification

Weight (7bs.)

1/2 Ton, 20' Lift

$1 / 2$ Ton Capacity;

10' Travel Manual Drive

Fixed Lead in for

Floor Valve

1,500 
TABLE 6.1 (Continued)

220A. 25 REFUEL ING SYSTEMS - PIPING AND VALVES

DESCRIPTION

LMFBR

TARGET PLANT

Floor Valves

Number

4

Dimensions

Classification

Weight (1bs.)

3.5' Diameter x 12" High

+ Actuator

5,200 
TABLE 6.1 (Continued)

\section{A.25 REFUELING SYSTEMS - MISCELLANEOUS EQUIPMENT}

LMFBR

DESCRIPTION

TARGET PLANT

Auxiliary Handling Machine

Dimensions

Stroke (ft.)

Number of Drives

Classification

Weight (tons)

Tanks

Quantity

Type

Fluid

Design Pressure

Design Temperature

Size

Volume

Material

Weight

Pumps

Quantity

Type

Fluid

Flow

Head

Design Pressure

Design Temperature

Material

Weight

Rating

Quantity

Type

Fluid

Flow

Head $6^{\prime} \times 6^{\prime} \times 75^{\prime}$ high

35

4

50

2

EVST NaK Exp. Tanks $\mathrm{NaK}$

65 Psia

$200^{\circ} \mathrm{F}$

$5^{\prime} \times 2.5^{\prime} \phi$

150 gallons

Carbon Steel
2

EM

Radioactive $\mathrm{Na}$

981 GPM

$100 \mathrm{ft}$.

100 Psia

$550^{\circ} \mathrm{F}$

304SS

$46 \mathrm{HP}$

2

EM

$\mathrm{NaK}$

$1141 \mathrm{GPM}$

$100 \mathrm{ft}$. 
TABLE 6.1 (Continued)

DESCRIPTION

LMFBR

TARGET PLANT

Design Pressure

Design Temperature

Material

Weight

Rating

Quantity

Type

Fluid

Flow

Coolant

100 Psia

$470^{\circ} \mathrm{F}$

$304 S S$

75 HP

2

ABHX Compressor

Air

Rating

$3.22 \times 10^{4} \mathrm{CFM}$ 
TABLE 6.1 (Continued)

220A.25 FUEL HANDLING AND STORAGE

DESCRIPTION

LMFBR

TARGET PLANT

Heat Exchangers

Quantity

2

Type

Fluid

Flow

Design Pressure

Design Temperature

Thermal Rating

Material

Weight

Heat Transfer Area

Quantity

Type

Fluid

Flow

Design Pressure

Design Temperature

Thermal Rating

Material

Weight

Heat Transfer Area

Quantity

Type

Fluid

Flow

Design Pressure

Design Temperature

Thermal Rating

Material

Weight

Heat Transfer Area

Purification

Quantity

Type

Fluid

Flow

Design Pressure

Design Temperature

Mesh

Material

Weight

2

EVST Cold Traps Radioactive Coolant

100 GPM

100 Psia

$400^{\circ} \mathrm{F}$

304 SS 
TABLE 6.1 (Continued)

DESCRIPTION

Quantity

Type

Fluid

Flow

Design Pressure

Design Temperature

Mesh

Material

Weight
LMFBR

TARGET PLANT

2

NaK Diffusion Traps $\mathrm{NaK}$

25 Psia

$250 \mathrm{~F}$

Carbon Stee1 
TABLE 6.1 (Continued)

\section{A.2611 INERT GAS RECEIVING AND PROCESSING}

LMFBR

DESCRIPTION

TARGET PLANT

Compressors
Quantity
Type
Design Pressure
Design Temperature
Flow
Material
Rating
Quantity
Type
Design Pressure
Design Temperature
Flow
Material
Rating

3

RAPS Compressors

9 Inlet/135 Discharge Psia $120^{\circ} \mathrm{F}$

25 CFM

$304 S S$

2

CAPS Compressors

9 Inlet/135 Discharge Psia $120 \mathrm{~F}$

$50 \mathrm{CFM}$

304 SS 
TABLE 6.1 (Continued)

220A.2612 GAS SUPPLY STORAGE SYSTEMS (TANKS)

DESCRIPTION

LMFBR

TARGET PLANT

LIQUID GASEOUS

Nitrogen Storage Tanks

Quantity

Design Pressure/Temperature, Psia/ ${ }^{\circ} \mathrm{F}$

He ight/Diameter

Volume

Material

Weight

\begin{tabular}{lc}
3 & 3 \\
$125 /-290$ & $250 /-290$ \\
$20^{\prime} / 7^{\prime}$ & $15^{\prime} / 10^{\prime}$ \\
$6000 \mathrm{Gal}$. & $6000 \mathrm{Gal}$. \\
\multicolumn{2}{c}{$304 \mathrm{SS}$}
\end{tabular}

Argon Storage Tank

Quantity

Design Pressure/Temperature

Height/Diameter

Volume

Material

Weight

24,000 lbs. 12,000 lbs.

Inert Gas Vacuum Tank

Quantity

Design Pressure/Temperature

Height/Diameter

Volume

Material

Weight

9

250/120 Psia/ ${ }^{0} \mathrm{~F}$

$7^{\prime} \times 6^{\prime}$

$1500 \mathrm{Ga} 1$.

$3045 S$

4000 1bs.

Inert Gas Delay Tank

Quantity

Design Pressure/Temperature

Height/Diameter

Volume

Material

Weight

2

$150 / 120 \mathrm{Psia} /{ }^{\circ} \mathrm{F}$

$14^{\prime}$ by $\zeta^{\prime} \phi$

$538 \mathrm{ft}$.

$304 S S$

10,000 lbs.

Noble Gas Storage Tank

Quantity

Design Pressure/Temperature

He ight/Diameter

volume

Material

2

$150 / 120 \mathrm{Psia} /{ }^{\circ} \mathrm{F}$

$25^{\prime} / 7^{\prime} \phi_{3}$

$960 \mathrm{Ft}$.

304SS

$20,0001 \mathrm{bs}$.

Weight

1

$150 / 120$ Psia/ ${ }^{\circ} \mathrm{F}$

$15^{\prime} / 5^{\prime}$

$300 \mathrm{Ft}^{3}$

304 SS

2,200 ibs. 
TABLE 6.1 (Continued)

\section{DESCRIPTION}

LMFBR

TARGET PLANT

Recycle Argon Tank

Quantity

Design Pressure/Temperature

1 Height/Diameter

Volume

Material

We ight

$150 / 120 \mathrm{Psia} /{ }^{\circ} \mathrm{F}$

$10^{\prime} \times 10^{\prime}$
$750 \mathrm{Ft}$.

304SS

8000 lbs. 
TABLE 6.1 (Continued)

220A.2613 INERT GAS PURIFICATION SYSTEMS (UNITS)

LMFBR

DESCRIPTION

TARGET PLANT

Nitrogen Vaporizer

Quantity

10

Flow

5,000 SCFM

Material $304 S S$

Argon Vaporizer

Quantity

9

Size

Flow

Material

5,000 SCFM 304 SS

Nitrogen Filter

Quantity

Mesh

2

Flow

Material

HEPA

500 SCFM

Weight

304 SS

500 lbs.

Argon Filter

Quantity

Mesh

Flow

Material

Weight

Vapor Traps

Quantity

Capacity

Material

Purification Unit

Quantity

25

5 SCFM

304SS

2

HEPA

250 SCFM

304SS

500 ibs. 
TABLE 6.1 (Continued)

\section{DESCRIPTION}

Nitrogen/Argon Charcoal Beds

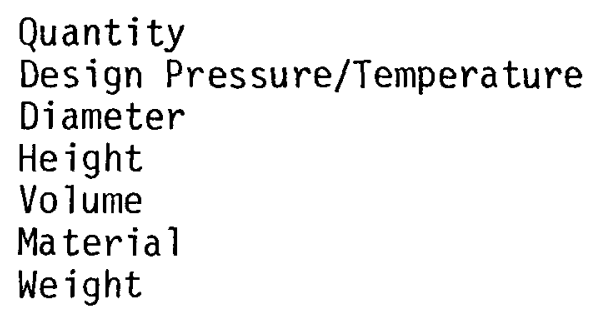

Distillation Unit

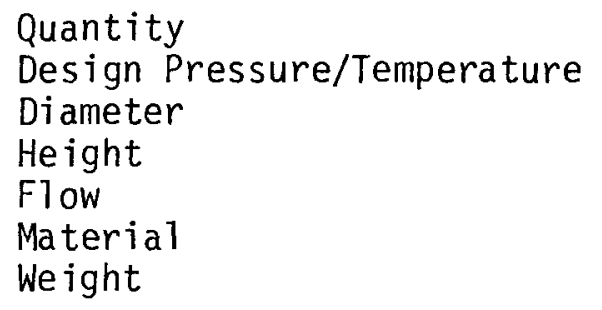

Heat Exchangers

RAPS Regenerative Heat Exchanger

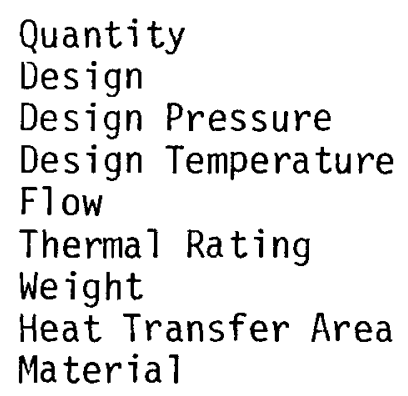

RAPS Argon Coolers

Quantity

Design Pressure

Design Temperature

Flow

Thermal Rating

Weight

Heat Transfer Area

Material

CAPS Nitrogen Cooler

Quantity

Design Pressure

Design Temperature

Flow
LMFBR

TARGET PLANT

5 $150 /-340 \mathrm{Psia} /{ }^{\circ} \mathrm{F}$ $14^{\prime}$ 28 ' $508 \mathrm{Ft}^{3}$ PCB Charcoal 10,000 lbs.

1 $150 /-320 \mathrm{Psia} /{ }^{\circ} \mathrm{F}$

-.--

25 SCFM

$304 S S$

2

Tube/Shell

150 Psia

$120^{\circ} \mathrm{F}$

25 SCFM

40,000 BTU/HR

$3045 S$

2

150 Psia

$120^{\circ} \mathrm{F}$

25 SCFM

40,000 BTU/HR

304SS

8

150 Psia

$120^{\circ} \mathrm{F}$

150 SCFM 
TABLE 6.1 (Continued)

\begin{tabular}{ll} 
& \multicolumn{1}{c}{ LMFBR } \\
DESCRIPTION & TARGET PLANT \\
Thermal Rating & 10,000 BTU/HR \\
Heat Transfer Area \\
Material
\end{tabular}


TABLE 6.1 (Continued)

220A.2615 PIPING, VALVES, AND FITTINGS

DESCRIPTION

Valves

Type

Size

Quantity

Material

Piping

Diameter

Length

Material

Freeze Vent

Quantity

Size

Material

Weight

Type

Quantity

Size

Material

Weight
LMFBR

TARGET PLANT

Plug

$2 "$ and Smaller

146

304SS

2" and Smaller

$1700^{\prime}$ CAPS

Carbon Stee1

$2100^{\prime}$ - PHTS Argon

$3045 S$

1500' - IHTS Argon

Carbon Steel

37

3" $\phi \times 30 "$

$3045 S$

450 ibs.

0 i1 Trap

8

$27 \mathrm{Ft}^{3}{ }^{3}$

$3045 S$

1000 Tbs. 
TABLE 6.1 (Continued)

220A.264 LIQUID METAL RECEIVING, STORAGE AND MAKEUP

DESCRIPTION

LMFBR

TARGET PLANT

Tanks

Quantity

Primary Na Storage

Fluid

Design Pressure

Design Temperature

Size

Volume

Material

Weight

8

Primary Coolant

15 Psia

$400^{\circ} \mathrm{F}$

$25^{\prime} \times 20^{\prime} \times 3 / 4^{\prime \prime}$

58,752 Gallon

$3045 S$

80,000 lbs.

Intermediate $\mathrm{Na}$ Storage Tanks

Quantity

Fluid

Design Pressure

Design Temperature

Size

Volume

Material

Weight

Nak Storage Tanks

Fluid

Design Pressure

Design Temperature

Size

Volume

Material

Weight
8

Secondary Sodium

175 Psia

$400^{\circ} \mathrm{F}$

$25^{\prime} \times 20^{\prime} \times 3 / 4^{\prime \prime}$

58,752 Gallon

304SS

80,000 Tbs.

3

$\mathrm{NaK}$

65 psia

$400^{6} \mathrm{~F}$

$7^{\prime} \phi \times 14^{\prime}$

3600 Gallons

304SS 
TABLE 6.1 (Continued)

DESCRIPTION

Filters

Quantity
Type
Fluid
Flow
Design Pressure
Design Temperature
Mesh
Material
Weight

Quantity

Type

Fluid

Flow

Design Pressure

Design Temperature

Mesh

Material

Weight

Valves

Quantity/Type

Tanks (0i1 Bubbler)

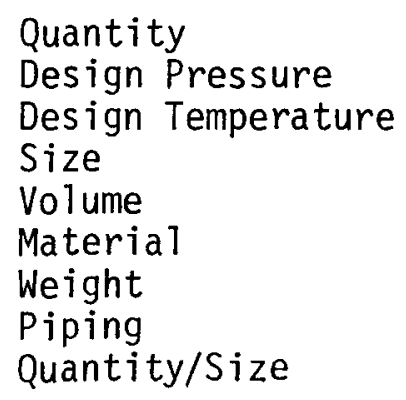

LMFBR

TARGET PLANT

2

Sodium Particulate

Sodium

180 GPM

25 Psia

$350^{\circ} \mathrm{F}$

20 Micron

304SS

1

NaK Particulate

$\mathrm{NaK}$

180 GPM

25 Psia

$70^{\circ} \mathrm{F}$

20 Micron

304SS

9/2" Plug, NNS

48/2" Plug, SC3

$16 / 3^{\prime \prime}$ Plug, NNS

6

20 Psia

$100^{\circ} \mathrm{F}$

$3^{\prime} \times 3^{\prime} \phi$

202 Gallons

Carbon Steel

1000 Ibs.

$1400^{\prime} / 3^{\prime \prime}$ SC 3

$1700^{\prime} / 3^{\prime \prime}$ NNS

$150^{\prime} / 3^{\prime \prime}$ SC3 
TABLE 6.1 (Continued)

220A.265 SODIUM PURIFICATION SYSTEM

DESCRIPTION

LMFBR

TARGET PLANT

Pumps

Overflow Pump

Quantity
Type
Fluid
Flow
Head
Design Pressure
Design Temperature
Material
Weight
Rating

2

EM

Primary Sodium

350 GPM

$105 \mathrm{Ft}$.

100 Psia

304SS

$30 \mathrm{HP}$

Primary Cold Trap Cooling Pumps

Quantity

2

Fluid

$\mathrm{NaK}$

Flow

160 GPM

Head

Design Pressure

Design Temperature

Material

Weight

Rating

$235 \mathrm{Ft}$.

100 Psia

$600^{\circ} \mathrm{F}$

304 SS

$30 \mathrm{HP}$

\section{IHTS Cold Trap Pump}

Quantity

Fluid

4

Flow

Intermediate Sodium

Head

70 GPM

Design Pressure

$200 \mathrm{Ft}$.

Design Temperature

200 Psia

Material

$640^{\circ} \mathrm{F}$

Weight

Rating

304SS

$10 \mathrm{HP}$ 
IHTS Cold Trap Cooling Pumps

\author{
Quantity \\ Fluid \\ Flow \\ Head \\ Design Pressure \\ Design Temperature \\ Material \\ Rating
}

Heat Exchangers

Quantity

Type

Fluid

Flow

Design Pressure

Design Temperature

Thermal Rating

Material

Weight

Heat Transfer Area

Quantity

Type

Fluid

Flow

Design Pressure

Design Temperature

Thermal Rating

Material

Weight

Heat Transfer Area

Tanks

Quantity

Primary Overflow

Fluid

Design Pressure

Design Temperature

Size

Volume

Material

Weight
2

NaK

$100 \mathrm{GPM}$

$200 \mathrm{Ft}$.

200 Psia

$600^{\circ} \mathrm{F}$

304 SS

$15 \mathrm{HP}$

2

Primary Cold Trap Regenerative Shell/Tube

Primary $\mathrm{Na} /$ Primary $\mathrm{Na}$

100/100 GPM

100 Psia

$970^{\circ} \mathrm{F}$

$8.59 * 10^{6}$ BTU/HR

304 SS

$150 \mathrm{Ft}^{2}$

4

Intermediate Sodium,

Regenerative She11/Tube

Intermediate $\mathrm{Na}$ /Intermediate $\mathrm{N}$.

100/100 GPM

100 Psia

$840^{\circ} \mathrm{F} * 10^{6} \mathrm{BTU} / \mathrm{HR}$

304 SS

$150 \mathrm{Ft}^{2}$

1

Primary Coolant

5 Psia

$950^{\circ} \mathrm{F}$

$25^{\prime} \times 20^{\prime} \phi$

58,752 gallons

304 SS 
HTS NaK Expansion Tanks

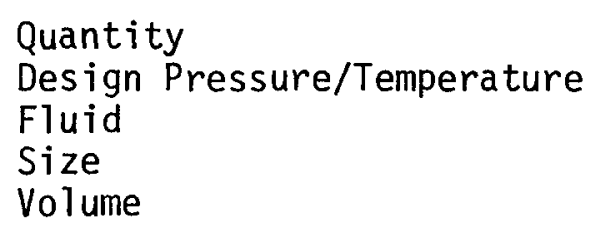

Filters

Quantity

Type

Fluid

Flow

Design Pressure

Design Temperature

Mesh

Material

Weight

Quantity

Intermediate Sodium Cold Trap

Fluid

Flow

Design Pressure

Design Temperature

Mesh

Material

Weight

Quantity

NaK Diffusion Cold Trap

Fluid

Flow

Design Pressure

Design Temperature

Mesh

Material

Weight

Valves

Quantity/Type

Piping
4

65 Psia $/ 400^{\circ} \mathrm{F}$

$\mathrm{NaK}$

$2^{\prime} \phi \times 3^{\prime}$

70 Gallons

3

Primary Cold Traps

Primary Coolant

$100 \mathrm{GPM}$

100 Psia

$400^{\circ} \mathrm{F}$

$3045 S$

4

Intermediate Sodium $70 \mathrm{GPM}$

200 Psia

$400^{\circ} \mathrm{F}$

$304 S S$

5

$\mathrm{NaK}$

25 Psia

$250^{\circ} \mathrm{F}$

Carbon Steel

6/2" Globe, SC2

8/3" Globe, NNS

$200^{\prime} / 3^{\prime \prime} \phi$ - 304SS

$400^{\prime} / 2^{\prime \prime} \phi$ - 304SS 
TABLE 6.1 (Continued)

\subsection{INSTRUMENTATION AND CONTROL SYSTEM EQUIPMENT}

DESCRIPTION

QUANTITY

Data Processing System

Plant Monitoring Computer

Plant Protection System (PPS)

Sensors

$\mathrm{BF}_{3}$ Counters

$\mathrm{BF}_{3}^{3}$ Counter Preamps

Stărtup Channel Safety Channel Drawers

Fission Chambers (3 Section)

Fission Chamber Preamps

Wide Range Safety Channel Drawers

Isolation Amplifiers

PHTS EM Flowmeters - 36"

IHTS EM Flowmeters - 36"

IHTS Venturi Diff. Pressure Transmitters

PHTS Pressure Transmitters

PHTS Temperature Transmitters (RTD)

PHTS Level Transmitters

I/I Converters (Isolation)

Power Supplies

Indicators

Safety Process Protective Cabinets

Core Monitoring Computers

Plant Protection System Cabinets

Reactor Trip Switchgear System

Remote Display \& Control Modules

Annunciators

4

4

4

4

4

4

4

4

Supplementary Reactor Protection System

Sensors

Temperature Transmitters (RTD)

Level Transmitters

SRPS Cabinets

SRPS Reactor Trip Switchgear Cabinets

Remote Display Modules

Annunciators

Containment Isolation System

Sensors

Gamma Monitors

8

Gas Monitors

8

Particulate Monitors

Ce11 Atmosphere Monitors

Cover Gas Monitors

ESF Logic Cabinets

4

Remote Display and Control Modules 


\section{DESCRIPTION}

In-Vessel Flux Monitoring System

Fission Chambers

Pre-Amplifiers

Subcriticality Monitors

Ex-Vesse1 Flux Monitoring System

Bio Ion Chambers

Linear Control Channel Drawers

Vessel and Internals Monitoring

Temperature Elements (In-Core TC)

Level Transmitters

CEA Pos. Transmitters

In-Vessel Accelerometers

Temperature Indicators

Equipment Operating Surveillance

Acoustic Transducers

Signal Conditioners

Pressure Transducers

Temp. Elements (TC)

Accelerometers

Speed Sensors

Torque Transmitters

Mass Spectrometers

Gamma Spectrometers

BF-3 Counters

Delayed Neutron Monitor

Data Handling System

LD Contact Detectors

LD Cable Detectors

Aerosol Monitors

Level Transmitters

Hydrogen Detectors

Hydrogen \& Gas Chromatograph

Oxygen Detectors

Disc-Rupture Sensors

Pressure Elements (Disc) 
TABLE 6.1 (Continued)

DESCRIPTION

QUANTITY

Control Systems

Recorder Indicator Controllers $\quad 27$

Controllers 13

Pressure Transmitters 5

Temperature Transmitters (RTD) 4

Process Instrumentation/PHTS and IHTS

Temperature Elements (TC) 80

Pressure Transmitters 36

Level Transmitters 24

Process Instrumentation/SG Systems

Temperature Transmitters (RTD) 8

Pressure Transmitters 32

Level Transmitters 64

Flow Transmitters 4

Temp. Rec. Controllers 8

Flow Rec. Controllers 24

Flow Meters 24

Level Rec. Controllers 16

Level Indicators 64

Pressure Indicators 32

Hand Ind. Controllers $\quad 72$

Hand Switches

Annunciators $\quad 576$

Control Switches 400

Temp. Indicators

Process Instrumentation/Intermediate Sodium Purification System

Temperature Elements $\quad 41$

Level Transmitter 4

Flow Transmitters 4

Temp. Indicators 21

Press. Indicators $\quad 15$

Flow Indicators 10

Temp. Indicator Controllers 8

Level Indicators 4 
TABLE 6.1 (Continued)

DESCRIPTION

QUANTITY

Process Instrumentation/Intermediate Sodium Purification System

Temperature Elements

Process Instrumentation/Primary Sodium Purification System

Pressure Indicators

Temp. Indicators

16

Pressure Transmitters

16

Flow Indicators

Level Indicators

Level Transmitters

Temp. Indicator Controllers

Flow Transmitters

Temp. Transmitters

Process Instrumentation/Sodium \& NaK Receiving System

Temp. Indicators

Pressure Indicators

Temp. Sensors (TC)

Pressure Transmitter

Process Instrumentation/Primary Sodium Storage and Processing

Leve1 Indicators

Level Transmitter

Temp. Elements

Temp. Transmitters

Flow Indicators

Flow Transmitters

Temp. Indicator Controllers

Process Instrumentation/Ex-Vessel Storage

Temp. Indicators

Temp. Transmitters

Temp. Sensors

Level Indicators

Level Transmitters

Flow Indicators

Flow Transmitters

Temp. Indicator Controllers 
TABLE 6.1 (Continued)

DESCRIPTION

QUANTITY

Process Instrumentation/Primary Sodium Cold Trap

Temp. Elements (TC)

12

Temp. Transmitters

6

Temp. Indicators

Flow Transmitters

Temp. Indicator Controllers

Flow Indicator

Leve] Indicator

Level Transmitters

4

2

2

1

1

Process Instrumentation/Intermediate Sodium Processing System

Temp. Indicators

Temp. Elements

Temp. Trans. (RTD)

Pressure Transmitters

Level Indicators

Level Transmitters

Flow Transmitters

Pressure Indicators

Pressure Transmitters

Component Control System

Solid State Component Cabinet

Control Element Drive Mechanism Control System

CEDMCS Cabinet

Piping and Equipment Electrical Heating System

Heaters

Thermocouples

$50,000 \mathrm{ft}$.

Temperature Controllers

Panels

Heat-Up Control Computer 
TABLE 6.1 (Continued)

\section{DESCRIPTION}

QUANTITY

Remote Shutdown System

Remote Hot Shutdown Panels

Handswitches

100

Temperature Indicators

Pressure Indicators

Level Indicators

Control Transfer Switch

PPS Status Panel

1

Temperature Recorders

Annunciators

Control Panels

Control Panels 